Florida International University

FIU Digital Commons

FIU Electronic Theses and Dissertations

University Graduate School

$11-3-2017$

\title{
"I am a Teacher, a Woman's Activist, and a Mother": Political Consciousness and Embodied Resistance in Antakya's Arab Alawite Community
}

Defne Sarsilmaz

Florida International University, dsars001@fiu.edu

DOI: $10.25148 /$ etd.FIDC004024

Follow this and additional works at: https:// digitalcommons.fiu.edu/etd

Part of the Community-Based Research Commons, Gender and Sexuality Commons, Human Geography Commons, Near and Middle Eastern Studies Commons, Politics and Social Change

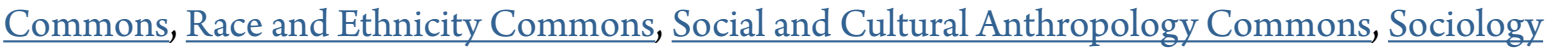
of Culture Commons, and the Sociology of Religion Commons

\section{Recommended Citation}

Sarsilmaz, Defne, "'I am a Teacher, a Woman's Activist, and a Mother": Political Consciousness and Embodied Resistance in Antakya's Arab Alawite Community" (2017). FIU Electronic Theses and Dissertations. 3542.

https://digitalcommons.fiu.edu/etd/3542

This work is brought to you for free and open access by the University Graduate School at FIU Digital Commons. It has been accepted for inclusion in FIU Electronic Theses and Dissertations by an authorized administrator of FIU Digital Commons. For more information, please contact dcc@fiu.edu. 


\section{FLORIDA INTERNATIONAL UNIVERSITY}

Miami, Florida

I AM A TEACHER, A WOMEN'S ACTIVIST, AND A MOTHER: POLITICAL CONSCIOUSNESS AND EMBODIED RESISTANCE IN ANTAKYA'S ARAB ALAWITE COMMUNITY

A dissertation submitted in partial fulfillment of the requirements for the degree of DOCTOR OF PHILOSOPHY in GLOBAL AND SOCIOCULTURAL STUDIES

by

Defne Sarsilmaz 
To: Dean John F. Stack, Jr.

Steven J. Green School of International and Public Affairs

This dissertation, written by Defne Sarsilmaz, and entitled I am a Teacher, a Women's Activist, and a Mother: Political Consciousness and Embodied Resistance in Antakya's Arab Alawite Community, having been approved in respect to style and intellectual content, is referred to you for judgment.

We have read this dissertation and recommend that it be approved.

Percy Hintzen

Vrushali Patil

Iqbal Akhtar

Caroline Faria, Co-Major Professor

Benjamin Smith, Co-Major Professor

Date of Defense: November 3, 2017

The dissertation of Defne Sarsilmaz is approved.

Dean John F. Stack, Jr. Steven J. Green School of International and Public Affairs

Andrés G. Gil Vice President for Research and Economic Development and Dean of the University Graduate School

Florida International University, 2017 
(C) Copyright 2017 by Defne Sarsilmaz

All rights reserved. 


\section{DEDICATION}

...this Dissertation is dedicated to the Arab Alawite women of Antakya, and to the three generation of women in my family; my grandmother Ilse, my mother Monika, and my sister Nur... 


\section{ACKNOWLEDGMENTS}

Researching and writing this dissertation has been an incredible journey and one that would not have been possible without the time, energy and care of the beautiful people listed below. Before I get into the names, I would like to thank FIU for the Dissertation Evidence Acquisition Fellowship in 2016 and the Dissertation Year Fellowship in 2017. With these two generous funding, I was able to enjoy the financial freedom to solely focus on researching and writing my dissertation and defend in a timely manner.

I would like to start by acknowledging my committee who has supported me since day one. I want to thank Caroline Faria for being my role model as a feminist geographer, for her thoughtful and detailed feedback on every single document I have sent her way, and for her encouraging words that helped sustain me throughout my graduate career. I want to thank Ben Smith for introducing me to Geography, for encouraging me by telling me how "great" I was doing all along the way, and for always having my back. I want to thank Percy Hintzen for his invaluable mentorship, his beautifully complex mind that challenges me in unimaginable ways, and for making me feel like part of his family. I want to thank Vrushali Patil for her postcolonial feminist perspective and her wisdom on Third World feminist scholarship. And finally, I want to thank Iqbal Akhtar for pushing me to rethink certain gender dynamics within Islam from an indigenous perspective.

I want to continue by thanking Sule Can and her family, who have taken me in and made me a part of their family during my fieldwork in Antakya. Whether 
introducing me to locals or including me in events, Sule has gone above and beyond for my research. Most importantly, she became a close friend and colleague in the field and beyond. I want to thank Tuncay Yilmaz for his weekly teachings on the political history of the Turkish Republican era, for setting up a good portion of the interviews, and his friendship. I want to thank Ugur Akgul for his companionship and hospitality and Suleyman Sayar for his support and humor.

I want to thank my favorite activist couple, Tulay Hatimogullari and Talat Oruc, for allowing me into their vibrant community. Tulay is the most bad-ass feminist activist and politician I know. The many conversations over Turkish coffee with Talat are invaluable and informed some critical aspects of my dissertation.

Akan Atakan, Tansel Dogruel, Umran Buyukasik, and Barbaros Duman gave me an extensive list of contacts that I interviewed and for that I am forever grateful. Hakan Kamil, Berna Berber, Hulya Kavuk, Meryem Kilic, Hazal Durgun, Seda Bilal, Nedime and Seda Yuce invited me into their homes and reminded me of the generosity and hospitality of our region. I want to thank Mahmoud Al Jabri, Rabih Torbay, Sultan, Omer Horoz, Sera Marshall, Gamze Gulec, Ahmet Aksakal whose friendships have made Antakya even more of an enjoyable experience.

As for the people who have fed me, went shopping with me, helped me look for housing, invited me for tea and coffee, stroke random conversations, showed me around, drove me around, gave me handmade and homemade goods, made me feel welcomed, there are just too many of you to list here, but be assured that you are not forgotten. I deeply value the interactions I had with the Antiochian community, 
especially with Arab Alawite women, who were so open in sharing their experiences with me and gracefully allowed me into their lives. I remain forever grateful and indebted.

I have such a wonderfully diverse academic community, including the late Ambassador Joe Melrose, Derrick Scott, Billy Hall, Orcun Selcuk, Onur Erpul, Ozum Yesiltas, Julia Meszaros, Oceane Jasor, Nichelle Calhoun, Jacqueline Lyon, Alex Huezo, Kimiko Tanita, Janna Lafferty, Ulrich Oslender, Ali Hamdan, and Peter Wood. Thank you for your inspiration and collaboration in this journey. I consider myself lucky to know each one of you.

I am grateful for my Miami community for making my stay in South Florida one of the best experiences in my life. I want to thank Jaime Diaz, Nilda 'Yayi' Sanchez and Melissa Maradiaga for always being there for me and being my 305 family. Joan Hintzen and Blossom Sullivan made me part of their family and introduced me to soca. Eric Joyner, Carmen Guiterrez, Xenia Dvoriantchikova, Brian Kerr, Carlos Gonzalez, Cory Hardaker, Geovanny Perez, Barry London, and Renata Eastlick spent time with me, sang with me, and made Miami a second home. Thank you all.

I want to thank my best friends Sarah Frazer, Nayna Gupta, Carla Louis and Berrin Ak for cheering me on, for listening to me, for being there for me no matter what. I want to thank Harry Michel, Sue Hodges, Kivanc Baltutan, and Sertan Onur for supporting me and my family. I am thankful for my fur babies Minik and Naylay for keeping me on my toes. 
Finally, I want to thank my family, especially my grandmother Ilse, mother Monika and sister Nur, my aunt Tine, and my aunt Barbie for raising me and helping me become the person I am today. I am also thankful for my nephew Lucas, father Erol, brother Derya, and uncles Claus and Henning. I am so grateful for Jared Miller, who has provided me with his unyielding love, support, and intellect during the final stretch of this journey. I love you all. 


\author{
ABSTRACT OF THE DISSERTATION \\ I AM A TEACHER, A WOMEN'S ACTIVIST, AND A MOTHER: POLITICAL \\ CONSCIOUSNESS AND EMBODIED RESISTANCE IN ANTAKYA'S ARAB ALAWITE \\ COMMUNITY \\ by \\ Defne Sarsilmaz
}

Florida International University, 2017

Miami, Florida

Professor Benjamin Smith, Co-Major Professor

Professor Caroline Faria, Co-Major Professor

Often pointed to as the region's model secular state, Turkey provides an instructive case study in how nationalism, in the name of conjuring unity, often produces the opposite effect. Indeed, the production of nationalism can create fractures amongst, as well as politicize, certain segments of a population, such as minority groups and women. This dissertation examines the long-term and presentday impacts on nationalist unity of a largely understudied event, the annexation of the border-city of Antakya from Syria in 1939, and its implications on the Arab Alawite population. In doing so, it deconstructs the dominant Turkish narrative on the annexation, rewrites the narrative drawing on oral history from the ground, and it shows how nation-building is a masculinist project that relies on powerfully gendered language through studying the national archives. The heart of the project, however, remains the investigation of the political, social, and religious subjectivity 
of Arab Alawite women, with an emphasis on resistance to the structures and practices sustained by the state and patriarchy.

The Arab Alawites, once numerically dominant in the Antakya region, are now an ethno-religious minority group within the Turkish/Sunni-dominated state structure. Although Antakya was the last territory to join Turkey in 1939, ever since that time many of its Alawites have resisted assimilation through covert, yet peaceful, methods. Through this research, I show that a multiplicity of forces have increased the politicization of the Antiochian Alawite community and broadened their demands upon the Turkish state. My research highlights Alawite women's leadership as a key driver of this process, thanks to the large-scale out migration of Alawite men, the increased socio-economic independence of Alawite women, and the perception of more progressive gender ideals being held by the members of this Muslim sect, when compared to those of nearby Sunni Turkish women.

This dissertation relies on a postcolonial and feminist geopolitical analysis of the Turkish nationalist project to examine how the Turkish state has historically viewed Antakya and the Arab Alawites and how, in return, the experience and collective social and political memory of Alawites was formed. By utilizing innovative methodologies, this research shows how Alawite women are resisting/rewriting/reconfiguring political and social structures through everyday actions that shift the discourse on minorities and women on local and national scales. 


\section{TABLE OF CONTENTS}

CHAPTER

PAGE

Terminology 3

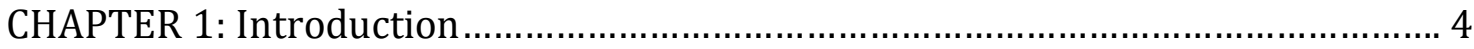

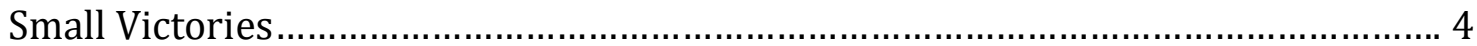

1.1. Why Antakya? …….............................................................................................. 8

1.2. Research Objectives and Questions............................................................ 11

1.3. Research Methodology: Positionality, Activist Scholarship, and the Anti-

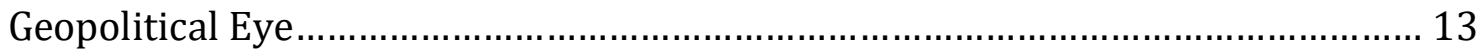

1.4. Theoretical Contributions: Feminist Geopolitics and Post-Colonial

Dispositions in the Middle East......................................................................... 20

1.4.1. Political Subjectivity and Interventions by Feminist Political

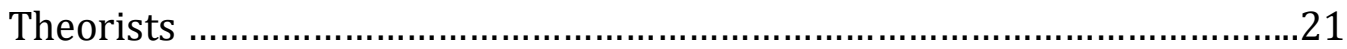

Embodied Nationalism/Citizenship .............................................. 24

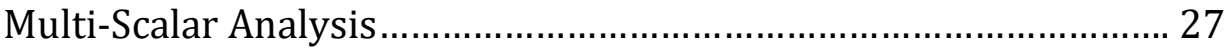

Reconfiguring Formal/Informal Politics.........................................30

1.4.2. On Feminist Geopolitics.....................................................................

What does a Feminist Geopolitics Look Like.....................................34

Applying Feminist Geopolitics to Antakya and the Archives...............36

1.4.3. Postcolonial Engagements with Feminist Political Geography .............37

Colonialism/Orientalism and the Modern State..................................38

Post-coloniality in the Middle East......................................................39

Feminist and Postcolonial Contributions.............................................41

1.1 Road Map

CHAPTER 2: Project Motherland: Antakya's Annexation in 1939 and its Implications for its Arab Alawite Population........................................................47

2.1. Whose Story Counts?: The Power of Oral History ............................................. 49

2.2. Re-framing Antakya as a Postcolonial Region ..................................................56

The Role of France in the Annexation Process............................................ 56

The Portrayal of Arab Alawites (Nusayris) ................................................ 61

The Construction of Arab-ness in the Turkish Nationalist Imaginary .......... 63

2.3. Turkey's Assimilation Politics...................................................................... 66

Power and Politics through Naming: "Hatay" - "Hata" - "Hittite".................. 66

Facilitation of Intermarriage and Language Courses .................................. 69

2.4. Gendered Language: Antakya as a Child/Girl Needing to be Saved ................... 72

Symbolism of Child/Girl........................................................................... 72

Gendered Narrative of Hatay in Captivity …………….............................. 76 
CHAPTER 3: Feminisms in the Muslim World: Arab Alawite Women's Religious

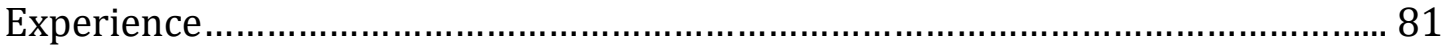

3.1. Brief Overview of Arab Alawism as a Belief System ..................................... 84

3.2. Women in the Arab Alawite Religious Order: Critiques from within .............87

3.3. The 'Accidental' Benefit of Women's Religious Exclusion ................................ 95

3.4. What do Arab Alawite Women Want in terms of Religious Inclusion ........... 100

3.5. Marriage Matters: Rules of Engagement and the Premise of Cultural

Preservation........................................................................................... 104

3.6. A Perceived Threat to Alawite Women's Social Freedom: The

Controversial Figure Mehmet Guven.............................................................. 108

CHAPTER 4: Process of Politicization in Antakya: Arab Alawite Identity, Leftist Movements, and Women's Involvement.

4.1. Political Articulations of Arab Alawite Identity: Leftist and Socialist

Tendencies

4.2. I am a teacher, a women's activist, and a mother: How the Leftist

Movement Politicized Women in Antakya

4.3. The 1980 Coup D'etat and the Aftermath: Implications on the Arab

Alawite Community

4.4. Political Party Affiliations: CHP, HDP, and Kemalism

4.5. Arab Alawite Identity on the Rise: The Syrian Conflict and Occupy Gezi

Protests

Syrian Conflict.

The Gezi Protests.

CHAPTER 5: We are always one step ahead: The Identity Construction of Arab

Alawite Women.

5.1. Embodied Performances of Identity: Dressing the Body and Ethnosexual

Imaginings

The Politics of Tesettur

The Construction of Arab Alawite Women as Religious and Sexual

Deviants

5.2. Reiterations of Modernity, Secularism, and Democratic Values

Democracy from within: Alawite Familial Structure and Women's Right

To Speak.

Religious Aspect: A Blessing in Disguise...............................................187

Secularism and the Leftist Movement.................................................,.....190

5.3. Socio-Economic Factors: Waged Labor and Female Education ...............,,.......193

Domestic Workers and Wage Earners: Arab Alawite Women's Role in the

Household Economy.....................................................................,.......193

Boom in Girl's Education.............................................................................201

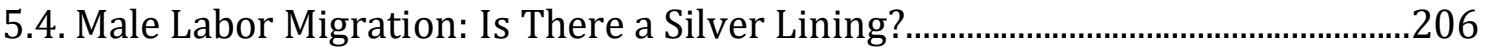


CHAPTER 6: Arab Alawite Women as Agents of Social and Political Change......211 6.1. Meddling in Men's Business: Arab Alawite Women's Interruption of Masculine Spaces 214

6.2. Intimacy Geopolitics: Embodied Resistance around Language Politics and Marriage/Divorce.

6.3. Resisting is in our Genes: Practicing Citizenship and the Power of Collective

Memory 226

6.4. Arteries of Antakya: Politicization and Resistance through Grassroots

Feminist Organizations

6.5. Birds Cannot Fly without both Wings: Feminist Critiques of the Left..........246

6.6. An Arab Alawite Women's Movement?

CHAPTER 7: Conclusion

260

7.1. Contributions to Feminist Geopolitics and Postcolonial Feminism

264

7.2. Wider Impacts

7.3. Future Implications: Prospects for Research on Arab Alawite Relations with other Minorities

269

List of References 274

Appendix .289

VITA 


\section{LIST OF FIGURES}

FIGURE

PAGE

Figure 0.1. Map of Turkey, www.mapcruzin.com ............................................

Figure 0.2. Map of Hatay, www.wikipedia.com...................................................2

Figure 2.1. A gathering of friends at a private home while playing/singing Arabic songs and eating traditional food during Ras el Seni, Arab Alawite New Year's,

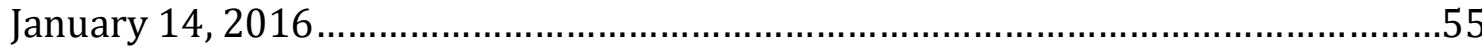

Figure 2.2. One of the four decrees that authorize state funding for cultural centers signed by Ataturk

Figure 2.3. Photo of a girl with a "Hatay" banner, standing between two soldiers, with a backdrop of Ataturk and the Turkish flag .............................................. 75

Figure 4.1. HDP Provincial Conference, March 3, 2016 ......................................145

Figure 4.2. Ghadir Humm Panel in Antakya, organized by Sheikh Ali Yeral. The panel included several Arab Alawite sheikhs. The backdrop includes a Turkish flag, a picture of Caliph Ali and of Ataturk, November 5, 2015.

Figure 6.1. Screenshot of the flyer for the "War-Violence-Women" Panel in Samandag.

Figure 6.2. Participants of the "Why we need socialist feminism" workshop at the Kadin Emegi Summer Camp, October 3, 2015

Figure 6.3. "We need feminism for peace" panel at the Kadin Emegi Summer Camp, October 5, 2015

Figure 6.4. Women's March on International Women's Day, March 8, 2016

Figure 6.5. Various leftist women's organizations in Antakya protesting together at the "Raise your Voice against Violence against women" event, November 25, 2015.

Figure 6.6. Arab Alawite Women's Council, Izmir branch, demonstrating on International Women's Day with banners in Arabic and Turkish, March 8, 2016 .253

Figure 6.7. Arab Alawite Women's Council demonstrating on May Day in Ankara, May 1, 2016 255

Figure 6.8. Arab Alawite women holding banner that reads "I am a Woman, I want Peace". 


\section{Map of Turkey}

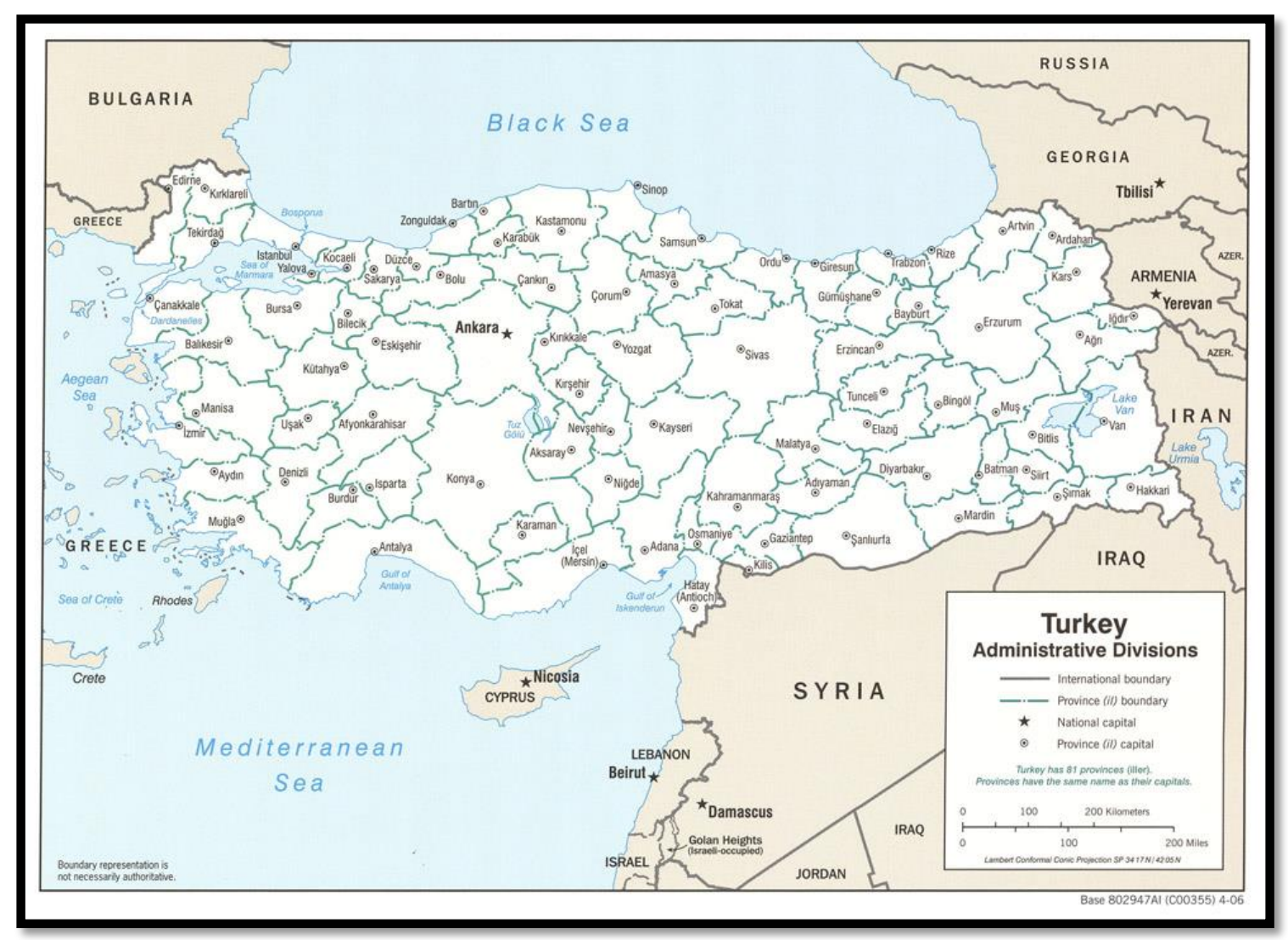

Figure 0.1. Map of Turkey, www.mapcruzin.com 


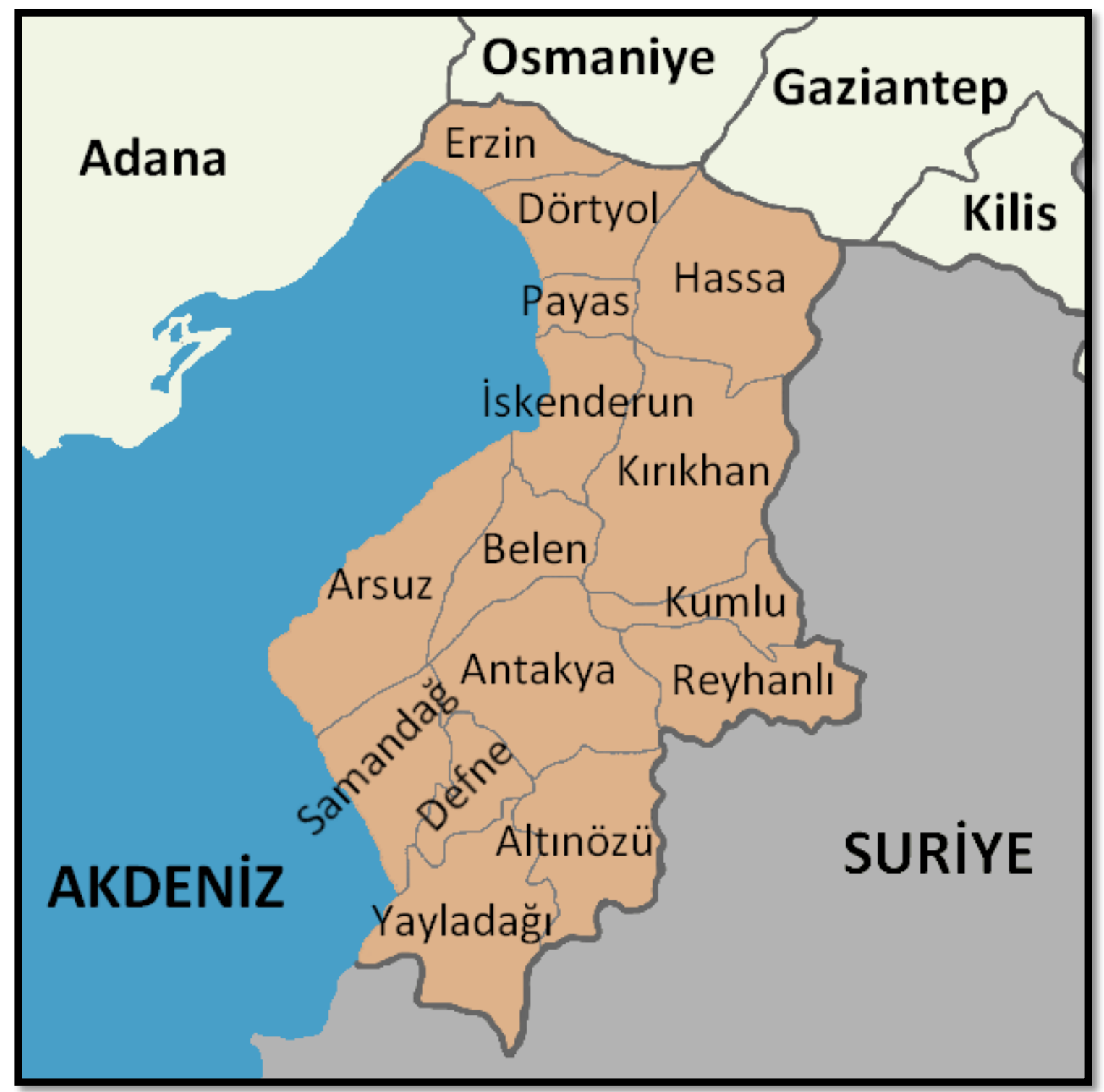

Figure 0.2. Map of Hatay, Wikimedia Commons 


\section{Terminology}

Arab Alawites are also known as 'Arab Alevis', 'Alevis', 'Alawis', and 'Nusayris'. While the former three are used interchangeably, the latter is somewhat controversial. There are still discussions within the Arab Alawite community whether the term 'Nusayri' is insulting. This topic was open for debate at the first Arab Alawite conference held in Antakya in November 2015 and participants had varying opinions, some arguing that the term was used to belittle or 'other' Arab Alawites in Turkey, while other argued that the term had historical accuracy (see Can, 2011 and Sertel, 2005 for further information).

I chose to use the term 'Arab Alawites' for this dissertation, because the community I worked in defined themselves as "Arap Alevi", which translates into Arab Alevi or Arab Alawite. I decided to go with the latter, mainly because it is the most common term in news media and literature on Arab Alawites, both in Syria and Turkey. It also helps avoid confusion between Alevis of varying ethnicities in Turkey, such as the Turkish Alevis and Kurdish Alevis, whom I at times refer to as 'Anatolian Alevis' as a group, to distinguish from Arab Alawites. In short, 'Alevi' and 'Alawite' share a common etymology and pronunciation, but I opted for 'Arab Alawite' due to the popular usage of the term in existing literature. 


\section{CHAPTER 1: Introduction}

\section{Small Victories}

"Look, Leyla Abla1, your fame has reached all the way to America," said the young man to Leyla, after she had stormed into the room, all flustered, conveyed the incident at the Arabic theatre the night before, and finally took a deep breath and asked someone to make her a cup of Turkish coffee to calm her nerves. Upon the remark of the young man, Leyla turned to me with a look of surprise, a humble smile spreading across her face, and introduced herself with a strong handshake. "How can I help you?" she said. For a moment, I did not know what to say. I was finally sitting in front of the woman, whose interview I had come across a year earlier, in which she had given a piece of her mind on the Gezi protests during the summer months in 2013. I had just started looking into women in Alevism and stumbled upon Leyla's interview with a local television program in Antakya. Her thick Arabic accent, strong feminist language, and unwavering determination had left me in awe. "Who is this woman?" I had thought to myself. Now, one year later, I was sitting in front of her, in a room full of people, at the community center of a socialist organization. She had reeled me in.

I like to think back at this encounter for several reasons. First and foremost, if it were not for Leyla's courage and outspokenness that mark her experience in the political and feminist struggle, I most likely would have not embarked upon this particular dissertation research. Secondly, this encounter neatly shows how discourse and practice are not separate, but are always supporting each other. Building onto this idea, it also shows how one initiative can cause a chain effect and result in positive outcomes. As one of the young women in the group that day said, "Our goals should not be confined to here. An organization, a movement here can be heard at another part of the world and cause some kind of a change". But this is not to say that goals and achievements are more validated on an international basis. On the contrary, local action is key, as Leyla's partner, Hilal, said:

"What's important is consistency. The Turkish state is very strong, it is very difficult to stand up against this system. What's important is to raise awareness on the local level, educate people and organize. The goal is local politics; we are aiming for small victories".

On November 21, 2015, I sat in a room full of Arab Alawite women discussing the religious, political, social, and cultural issues Alawite women face (as part of the first Arab Alawite conference held in Antakya). Participants of the workshop, as did many of my female interviewees, protested the male-centered knowledge production on the Arab Alawite society in Turkey. The few researchers, who had taken an interest in this ethno-religious minority group, had been mostly male outsiders who exoticized the concealment in the Arab Alawite religious system and were primarily interested in

1 'Abla' means 'older sister' in Turkish. It is used as a sign of respect when informally addressing a woman that is older than you. 
speaking to the male members (particularly the sheikhs) in the community. Even during my fieldwork, several women offered to put me in touch with some of the revered men in their community. For the most part I gracefully declined their offer, explaining that my research focus was on Alawite women. "It's about time," many of them replied. Through this research, I hope to offer a glimpse of the lives Arab Alawite women in Antakya lead, amidst increasing Sunnification of political and social affairs, rising ethnic and sectarian tension in the region (partially due to the ongoing Syrian Conflict), and hegemonic masculinity. The women I met, and many others, challenge these structures and events through overt and covert acts, through political and feminist organizing, and by trying to shift political and social consciousness locally and nationally. As such, this work is an important contribution to the body of discourse and practice on Muslim women in the Middle East and their agency within the past and present geopolitical shifts in the region.

Since the beginning of the 20th century, the Middle East has seen waves of significant political shifts driven by nationalist sentiments - the most recent of which has been the "Arab Spring". These nationalisms are produced through contestations around religious and secular ideologies, ethnic difference and gender ideals. Often pointed to as the region's "model" secular state (Gumuscu, 2010; Secor, 2011), Turkey provides an instructive case study in how nationalism, in the name of conjuring 'unity', often produces the opposite effect. Indeed, the production of nationalism can create fractures amongst, as well as politicize, certain segments of a population, such as minority groups and women. This dissertation examines the long-term and present-day impacts on nationalist unity of a largely understudied event, the annexation of the border-city of Antakya from Syria in 1939, and its implications on the Arab Alawite population. In doing so, it deconstructs the dominant Turkish narrative on the annexation, rewrites the narrative drawing on oral history from the ground, and it shows how nation-building is a masculinist 
project that relies on powerfully gendered language through studying the national archives. The heart of the project, however, remains the investigation of the political, social, and religious subjectivity of Arab Alawite women, with an emphasis on resistance to the structures and practices sustained by the state and patriarchy.

The Arab Alawites, once numerically dominant in the Antakya region, are now an ethno-religious minority group within the Turkish/Sunni-dominated state structure. Although Antakya was the last territory to join Turkey in 1939, ever since that time many of its Alawites have resisted assimilation through covert, yet peaceful, methods (Can, 2011; Mertcan, 2014). Increased "Sunnification" of political and social spheres after the 1980 coup d'état, and now the ongoing conflict in neighboring Syria (which is in part fought between Sunni militias and the Alawiteled Syrian state), has only served to heighten the sense of an ethnic and sectarian divide. Through this research, I show that a multiplicity of forces have increased the politicization of the Antiochian Alawite community and broadened their demands upon the Turkish state. These forces include state practices that heighten spatial discrimination based on religious and ethnic difference, vibrant and powerful forms of formal and informal resistance that are both local and national, and the increasing visibility of Arab Alawite women. My research highlights Alawite women's leadership as a key driver of this process, thanks to the large-scale out migration of Alawite men, the increased socio-economic independence of Alawite women, and the perception of more 'progressive' gender ideals being held by the members of this Muslim sect, when compared to those of nearby Sunni Turkish women. 
In the absence of research examining the implications of the postcolonial condition and the relentless nation-building project on the region's Arab Alawite population, our understanding of the complexity of forces and the trajectories of change that operate in the region remain fundamentally limited. This dissertation responds by using a postcolonial and feminist geopolitical analysis of the Turkish nationalist project to examine how the Turkish state has historically viewed Antakya and the Arab Alawites and how, in return, the experience and collective social and political memory of Alawites was formed. Utilizing innovative methodologies, this research uses feminist and postcolonial analysis to show how Alawite women are resisting/rewriting/reconfiguring political and social structures through everyday actions that shift the discourse on minorities and women on local and national scales.

In this introductory chapter, I begin by discussing why I chose Antakya as my regional focus and what makes this border region particularly important. I will then outline my research objectives and questions, followed by my research methodology. In the following section, I will provide a review of the literature on feminist political geography, with a focus on feminist geopolitical and postcolonial scholarship, as well as literature on minority and nationalism in the Middle East, with a narrower focus on post-Ottoman Turkey. Finally, I will provide a detailed roadmap for the remaining chapters. 


\subsection{Why Antakya?}

Following World War I and the collapse of the Ottoman Empire in 1918, France held the territories of Syria and Lebanon until 1943. In 1938, Antakya - then part of Syria - became its own state under joint French and Turkish supervision. Turkey, which had become an independent state in 1923, continuously protested, arguing that 'Hatay' was Turkish and had to be reunited with Turkey. Putting pressure on the French, the Turkish state asked for a referendum of the local population and as a result annexed Antakya in 1939, despite Syrian discontent. However, the validity of the referendum is considered questionable, because leading up to the referendum and right after, the Turkish state systematically created settlements in Antakya to increase the local Turkish population and overwhelmingly registered Turkish voters to take part (Duman, 2016). It is also important to note that announcements for the voting registration and the referendum were made in Turkish, not taking into consideration the non-Turkish speaking communities (Duman, 2016).

As a result of the annexation of Antakya, the local Arabic-speaking Alawite population (as well as Sunni and Christian Arabs) became Turkish citizens, but, by and large, identified more strongly as Arab Alawites than as Turks. Their resistance to Turkish authority has been less strident than that of the more well-known Kurds and Turkish Alevis, but they have nonetheless held steadfastly to their beliefs, rituals, and language (Can, 2011; Yilmaz, 2013; Mertcan, 2014). This separation has recently grown stronger and more divisive given the war in Syria, which has 
heightened discrimination by Turks against Alawites, whom they have increasingly come to view as "the Other" (Can, 2011).

Antakya is home to the majority of Turkey's Arab Alawite population, who make up around 35 percent of the province's population (Dogruel \& Leman, 2009). The rest of the province's population includes Turkish Sunnis (around 50 percent), Arab Sunnis (10 percent), and the rest a mixture of Arab Christians, Kurds, Circassians, Jews, and Armenians (Dogruel \& Leman, 2009). Antakya's multicultural composition is celebrated by the local population, but they do not really mix (Dogruel \& Leman, 2009; Can, 2011). For the most part, ethnic minorities were able to preserve their respective languages, but they were still subject to assimilation policies throughout the Republic era, beginning from the 1920s until today. In the case of Arab Alawites, they have faced double persecution in practice and policy, due to their ethnic and religious status. For example, throughout the Ottoman and Republic eras, they have faced pressures to abandon their mother tongue and have been subject to Sunnification policies, as they are considered deviants of Islam by Sunni Muslims (Mertcan, 2014).

In recent decades, especially after the 1980 military coup d'état, the Sunnification of Turkish politics, education system, and social sphere has only enhanced the process of cultural assimilation. That is, Turkey's professed secularity has eroded in favor of Sunni dominance. The 1980 coup, "cleansed the public sphere from extreme ideological groups" (Caha, 2004: 328), but at the same time, "fostered the role of (Sunni) Islam as a constitutive part of national Turkish identity" 
(Dressler, 2008: 281). With the Justice and Development Party (AKP) coming to power in 2002, Turkey has been experiencing a rise in political Islam informed by Sunni beliefs and practices. This has stirred up anger among the country's minorities, including the Alawites and other non-Sunni Muslims. The Turkish Alevi massacres (Malatya 1978, Maras 1978, Corum 1980, Sivas 1993), the increasing authority of the Department of Religious Affairs, and the mandatory Sunni religion classes within the public education system have further stoked the flames of nonSunni Muslim minority resistance.

The existing literature on Antakya's unique positioning vis-a-vis the Turkish state often fails to move beyond a descriptive focus on its status as a multi-cultural region (see Dogruel \& Leman, 2009); paying little attention to ethnic, religious and gendered fractures within the social fabric of the region and their broader implications. Existing literature takes a largely descriptive historical or anthropological approach (see Turk, 2005; Dogruel \& Leman, 2009; Can, 2011; Mertcan 2014). While these works provide insightful knowledge on the history of Antakya and its multi-ethnic, multi-religious composition (Dogruel \& Leman, 2009), give detailed information on the religious, social, and political construction of the Arab Alawite identity (Mertcan, 2014), and reveal the various assimilation tactics Alawites resisted (Can, 2011), they do not frame Antakya as a postcolonial region, nor do they pay attention to the gendered aspect of the Turkish nation-building project. A more recent publication by Duman (2016) goes into more depth about the annexation of Hatay and the Turkish nation-building project, however it could be 
reinforced with a postcolonial analysis. This dissertation does just that; it extends existing scholarship on Antakya and the Antiochian Arab Alawite community, while pushing against the dominant annexation narrative, all the while staying critical of the intersections of gender, class, ethnicity, religion, and nationalism. Furthermore, it brings women's voices to the forefront and shows the richness in the experiences of Muslim women in the Middle East.

\subsection{Research Objectives and Questions}

Objective 1: To identify patterns of the rise in formal and informal acts of resistance among Arab Alawite women and to examine the effectiveness of these new womenled activist movements in transforming their community, improving their positioning vis-à-vis the Turkish State, and connecting to other gender-based activist movements in the wider geopolitical region.

Sub-questions: (a) What are some of the 'formal' and 'informal' political resistances Alawite women are engaged in? (b) What are the tangible and intangible impacts of these resistances in their communities? (c) Through which platforms are Arab Alawite women connecting/ collaborating with other minority and gender-based activist movements in the region?

Objective 2: To interrogate how connected conflicts around religion, ethnicity, and gender have shaped relations between Antiochian Alawites and the Turkish State.

Sub-questions: (a) What are the ways Arab Alawites construct their religious, social, and political identities, particularly compared to Turkish Sunnis? (b) Do Arab 
Alawites reinforce and/or re-appropriate the construction of their 'Otherness', and if so, how? (c) How does this subvert/reinvent/reinforce wider imaginations?

Objective 3: To determine the historical and geopolitical relationships amongst the region of Antakya, the Turkish State, and Turkish nationalism.

Sub-questions: (a) How was Antakya constructed within the Turkish national imaginary since its annexation from Syria in 1939? (b) How have the events around the annexation shaped the collective memory of Arab Alawites in Antakya? (c) What are their experiences with and attitudes towards Turkish nationalism and panArabist ideologies?

These objectives serve to embed Antakya in the wider geopolitical and historical context, producing a deeper understanding of the positioning of Arab Alawites within the Turkish nationalist imaginary and marking the region 'postcolonial'. Moreover, they help us understand how the annexation shaped Alawite collective memory and how the political climate in Turkey since then politicized this minority group. And most importantly, these objectives get to the core of the rise of Alawite women's political consciousness by investigating the beginnings of their politicization, their positioning within the Alawite society, and the various acts of resistance they engage with on multiples scales. 


\subsection{Research Methodology: Positionality, Activist Scholarship, and the "Anti- geopolitical Eye"}

For a long time, the Cartesian perspective was valorized by social scientists, claiming the researcher could remain objective and untouched. An epistemological shift happened with Donna Haraway's groundbreaking essay in 1988, in which she challenged the "God trick", which is the detached, all-seeing eye. She argued that every researcher brings in their own perspectives and experiences into their research and produce "situated knowledges". With this shift, feminist scholars began incorporating positionality and reflexivity into their research. As researchers, we "must examine [our] own motives, and the effects of [our] actions, as both researcher and activist[s]" (Kobayashi, ed. Limb and Dwyer, 2004: 55). Robina Mohammad's essay on the 'insider' and 'outsider' position of the researcher pushed me to be more aware of my position as a multi-national woman, who grew up in Western Turkey, and is educated in the United States (ed. Limb and Dwyer, 2004). I understand the implications of these layers and how they position me as a researcher within this ethno-religious minority group. I regard myself both an insider and an outsider to the Arab Alawite community. I like to think of myself as an ally and I try not to "speak for" Arab Alawite women, but provide a platform for their voices to be heard (England, 1994). As part of the feminist geopolitical approach, a grounded, participatory research remains crucial for the "antigeopolitical eye" (Ó Tuathail, 1996; Dowler and Sharp, 2001). 
My position within this research project is multi-layered. While I am considered an 'insider' due to being from Turkey and speaking Turkish, I am also considered an 'outsider', since I am not Arab Alawite (Mohammad, ed. Limb \& Dwyer, 2004). I am aware that I speak from a privileged position considering my ethnic Turkish background and my Western education. My experiences on the field were shaped by my multi-layered position. The knowledge I produce will be partial and situated, as it will be infused with my own subjectivity.

While in Antakya, I worked with a vibrant and determined group of women involved in not only local, but also national politics, through political parties, community organizations, and feminist platforms. These women are working towards empowering the Alawite community, fighting violence against women, protesting neoliberal policies implemented by the state, and are building social and political alliances with different ethnic and religious minority groups in Turkey and the Middle East. Service research, or activist scholarship, aims to meet the needs of the community where the research is conducted. Authors like Akkaya (2014) seek to amplify the voices of minority women that have been overlooked in current scholarship on women in the Middle East. This research diversifies the literature on women within ethnic and religious minority groups in Turkey.

During my fieldwork, I built alliances with my research collaborators and offered my skill sets for their endeavors. I became affiliated with the Research Institute for the Middle Eastern Arab Peoples and translated several documents from Turkish into English and wrote articles about the politicization of Arab Alawite 
women in Antakya for their website. I also became a volunteer for their oral history project, for which we visited and interviewed elderly people who had substantial recollection of Antakya's annexation period. I distributed People's Democratic Party (HDP) campaign flyers, showed support at public events such as conferences, symposiums, cultural festivals, film screenings, protests, and concerts. I continue to revise and translate documents and write articles for the Research Institute when needed and I am in continuous communication with several of my research collaborators. Some of my female interviewees urged me to publish my dissertation in Turkish, as there are no sources on Arab Alawite women. Lawyer, feminist activist, and politician Songul particularly encouraged me to publish and even offered to connect me with some publishers.

In this sense, I remain committed to the people, especially the women, that I have connected and collaborated with during and after the field, as I believe the field never remains a distant place, "then and there" (Hyndman, 2001). I want my work to be accessible to the women who have given their time, trust and devotion into my research. I believe a feminist framework is not only valuable in understanding political subjectivities and political activism within different geographies, but it also has the ability to position the researcher as an activist for social change, both within and outside of academia (Wright, 2008). Personally, I cannot think of any other way of doing research.

Activist scholarship tries to bridge the gap between research and activism (Kobayashi, ed. Limb \& Dwyer, 2001). For Kobayashi, doing feminist research means 
providing a way for women to change their lives through voicing their experiences and "by providing a basis for critical feminist scholars to become involved in that change" (Kobayashi, ed. Limb and Dwyer, 2004: 59). Kobayashi claims that feminist research means producing activist scholarship and taking a political stand. By engaging in the 'real situations' of Filipina domestic workers by showing the "embodied pain of forced migration" and the works of the Philippine Women Center, Pratt also takes a political stand by advocating for a change in the rights and treatment for migrant workers (2004: 7). Trauger \& Fluri (2014) call this "service research", also known as participatory action research, in which research questions emerge from the engagement with the community and the researcher frames the project to meet the needs of that community. While some of my research questions were formed prior to my fieldwork, most of them emerged while in the field. I also continuously asked for feedback from my interviewees, both on my interview questions and on outreach methods.

As part of my ethnographic study and participant observation, I spent a total of ten months in Antakya, in July 2014 and August 2015 - May 2016. I resided in one of the major Alawite neighborhoods called Affan in central Antakya. By living in an Alawite neighborhood, I immersed myself in the way of life and events of Alawites and it also helped me connect with people for my research. I regularly socialized with members of the community and frequently visited cultural and political associations, offices of political parties, and the Research Institute. I recorded events, speeches, and other public conversations occurring at these sites, 
utilizing extensive notes and photography - paying particular attention to how the Turkish state is critiqued and around which issues these groups mobilize. I also collected visual and textual ephemera circulated in these places. Throughout my fieldwork, I collected secondary data which includes records relating to the operations of municipalities, sectioning of Alawite neighborhoods, census data, and any other related operations that interrogate how governing practices shape the relationship between Arab Alawites and the state.

Through my archival research at the Ankara Prime Ministry's State Archives (specifically examining the folders on national celebrations after the annexation) I collected textual and visual materials that document the events leading up to and following the annexation of Antakya. I particularly paid attention to Turkish nationalist discourse in justifying the annexation, Turkish settlement activities, assimilation tactics, and local resistance. The State Archives in Ankara provided an excellent opportunity to analyze documents from the late 1930s, leading up to and following the annexation of Antakya from Syria in 1939. My search keywords in the digitized catalog system were "Antakya”, "Hatay", "Alawites", “Nusayris”, and "the Hatay Issue". I identified a document as 'relevant' to my research if it had a component of gender, ethnicity, religion, nationalism, state policies, and annexation politics. As a native Turkish speaker, I had few problems reading and processing the documents, with the exception of a small number of documents that were written in Arabic alphabet, mostly before 1935 (thus relatively far from to the annexation of Antakya in 1939). I received the requested documents electronically on a CD, so that 
I could code my findings for a more in-depth analysis. As data analysis proceeded, several themes emerged. These themes have strong gendered tones, marked by postcolonial and nationalistic sentiments, such as scripting Antakya as ancient Turkish land and Arab Alawites as "authentic Turks", the normalization of this national script, and the symbolic use of infancy and femininity in production of these dominant narratives.

Archives are rich research sites where various racialized, gendered, sexualized, and classed discourses of the nation-building project can be traced back in time (Stoler, 2009). What is said (and what is unsaid) in the history-making process reveals substantial information about past and present structures of power and the institutionalization of certain discriminatory state and social practices. Therefore, the archives were a fitting starting point to start questioning the production of "Hatay" within the Turkish national imaginary.

I organized four focus groups, of which one consisted of 25-30 women, one of five women, and the other two were mixed-gender, with 5-7 participants. I tailored questions according to the participants of the group, but for the most part, I focused on collecting narratives about discrimination and belonging in Antakya, the meanings and practices of politicization, and performance of gendered Alawite identities and how it is contrasted to the way other identities are perceived. The allwomen sessions were recorded, using thick descriptive notes. I also often found myself in group settings that formed organically and used the opportunity to ask 
questions and generate discussions about my research objectives. I did not record these conversations, but took extensive notes.

Participant observation and focus groups provided an opportunity to identify Alawite women, and men, who are actively resisting dominant structures through formal and/or informal acts. Given the time frame, I interviewed fifty-two women and fifteen men using an in-depth, semi-structure interview tool. This tool helped interrogate how tensions around religion, ethnicity, and gender shape relations between Alawites and the state and identify the formal/informal acts of resistance against dominant power structures. These interviews complement the focus groups by providing rich, in-depth insights into gender ideals, religious and political ideologies, and activism among the Alawite community in Antakya.

I identified four publications that focus on women (Kadin Emegi), Arab Alawites (Ehlen and Kaldirim), and minority politics (Siyasi Haber) for visual and textual discourse analysis. These monthly publications include intellectual and empirical contributions by Antiochians and other political and feminist activists. I read and analyzed articles that show how the Arab Alawite collective memory is constructed, what their demands are as a marginalized minority, and what actions they are taking to reach their goals. I also found articles that investigate gender structures within Turkey and the Arab Alawite society, women in Arab Alawism, and feminist activism in the local and national context. 


\subsection{Theoretical Contributions: Feminist Geopolitics and Post-Colonial Dispositions in the Middle East}

The intellectual and practical contributions of this dissertation on feminist political geography, specifically feminist geopolitical scholarship, is twofold. My research expands existing literature on third world feminism pertaining Muslim women's experiences and secondly, provides tangible knowledge for Arab Alawite women to be used as a reference point and to further their political and feminist struggles. This research inserts itself into third world feminist scholarship, particularly feminist work on Muslim women's subjectivity and agency. Feminist scholars from various disciplines have articulated alternative narratives of Muslim women in the Middle East and beyond, unsettling the Western perception of the oppressed and passive Muslim woman who needs saving (Abu-Lughod, 2002; 2010; Fluri, 2008; 2009; Secor, 2001; 2004; Gokariksel and Secor, 2010). Through exploring Arab Alawite women's social and political subjectivity, which rests its roots in a secular interpretation of Islam, this dissertation offers an alternative understanding what it means to be a woman in the Muslim Middle East.

In this arena, works of feminist scholars on Islam are pertinent in understanding the diverse experiences of Muslim women in the Middle East from an indigenous standpoint (Göle, 1997; Mahmood, 2001; Abu-Lughod, 2002; Bora, 2008; Aldikacti Marshall, 2010; Badran, 2009; Arat, 2010; Diner and Toktaş, 2010; Gökarıksel and Secor, 2010; Gürhan, 2010). Such scholars highlight the intersection of feminism and Islam and engage with secular Muslim feminist and Islamic feminist 
expressions. Badran's work (2009) offers a remarkably detailed discussion of feminisms in Islam across an array of countries not limited to the Middle East. Particularly relevant to this dissertation are the works of feminist theorists on Islamic and secular feminisms in Turkey. One of the most prominent Turkish feminist scholars on Islam, Göle (1997), very early on points to the tension between an secularist practice of Islam and an Islamist elitist practice, highlighting its repercussions for women. This tension has sadly reached new heights since the publishing of her article. Fellow Turkish feminist scholar, Aksu Bora (2008), critiques the Western approach women's studies in the Middle East by pointing out how such studies have largely ignored the role of the state in determining the theoretical and practical aspects of Islam, hence calling for a more political approach rather than a cultural one. This dissertation is responding to Bora's call for implementing a political framework in researching women's movements and gender in the Middle East, by investigating the complex relationship between the Turkish state, postcolonial legacy, Muslim minority struggles, and women's political activism. In this regard, my research pushes the boundaries of existing scholarship on Islam\& gender and feminist movements in the context of Turkey.

\subsubsection{Political Subjectivity and Interventions by Feminist Political Theorists}

Mainstream political theorists and political geographers have contributed to the studies of political activism and political subjectivity, primarily through a focus on "elite agents" (Dittmer, 2013). While important strides were made in better understanding the state, nation, citizenship, nationalism, and social movements, 
theorizations remained on grand-scales and reestablished meta-narratives. Scholars from the disciplines of feminist political science, feminist international relations, postcolonial feminism, and feminist political geography have critiqued the masculinist, abstract, Eurocentric, and disembodied perspective of mainstream political theorists.

The intervention made by feminist political theorists has sought to address the shortcomings of mainstream political theory, political geography and critical geopolitics. While traditional political theorists and political geographers often portrayed citizens as abstract and passive subjects, feminist scholars sought to locate power and agency within women and the marginalized. Furthermore, mainstream political geographers looked at social movements as the main form of political activism, disregarding everyday and smaller-scale acts as 'political'. Almost no attention was paid to how space is inscribed by masculinity/femininity. Since women have historically been ascribed to the private and domestic spheres, political activism has been primarily associated with men. Feminist scholars unsettled these notions by not only looking at the 'category woman', but also in the complex operations of gender, and how gender and sexuality are interconnected with social differentiation and the marginalization of certain groups (McDowell, 1999; Pratt, 2004; Staeheli, ed. Staeheli, Kofman, and Peake, 2004).

Feminist research surrounding political subjectivity and political activism started incorporating issues of racialization, decolonization, and the third world with postcolonial feminism (Alexander, 1994; Wangari, 2002; Narayan, 1997; 
Grewal, 1998; McClintock, 1997; Mohanty, 2003; Spivak, 2006; Kelly and Kaplan, 2004). Feminist scholars of this tradition demonstrated how colonialism and racism played an indisputable role in the construction of political subjectivity. They also highlight the importance of not homogenizing or essentializing the postcolonial subject, since "identities and experiences are constructed through historically and geographically specific instances of struggle." (Sharp, 2003: 66).

Feminist scholars from political science and international relations traditions have also interrupted the masculine discourse within their fields. Feminist political scientist Iris M. Young's (1990, [2011]) intellectual contributions have not only advanced feminist political theory on group identities and social differentiation, but also contemporary theories on social justice, democracy, and oppression. Cynthia Enloe (1989) has enhanced feminist scholarship on political subjectivity through a gendered, multi-scalar analysis of international relations. Her renowned work on military, tourism, and the global market investigates the complex operations of gender within these sectors, while showing how the international and the local impact one another.

In short, feminist scholars from a variety of disciplines have contributed to re-thinking and re-configuring political subjectivity and political activism. To begin with, feminists treated the body as a site, where embodied performances of nationalism play out. Women's bodies come under scrutiny within the nationalist discourse, because they symbolize moral and national boundaries. Hence, nationalism is always already gendered and sexualized (McClintock, 1997). Feminist 
scholars have urged a multi-scalar analysis when looking at political subjectivity and activism, because narratives of the household and the community have often been overlooked. Looking at smaller scales did not mean feminists had to compromise on larger scales. The inter-connectedness of the local and the global, the home country and the Diaspora, the household and the nation have been laid bare through a multiplicity of research studies. Finally, feminist scholars were among the first to count 'informal' and 'private' acts as 'political', through which they made women's political activism more visible.

\section{Embodied Nationalism/Citizenship}

As part of re-thinking political subjectivity, the body became an important site for feminist theorizing (Valentine, 1989; Longhurst, 1997; McDowell, 1999; Johnston \& Longhurst, 2010). Viewing the body 'as place' and observing bodies 'in space' lead feminist scholars to center their work around the concept of 'embodiment', which meant that bodies are not fixed, but fluid, always becoming and performing (McDowell, 1999). Butler's (1999) work on gender performativity introduced gender as bodily performance. By the same token, feminist political scholars began interpreting nationalism as gendered performance and the body as a site where nationalist scripts play out (Yuval-Davis, 1991; 1997; Nagel, 2003; Faria, 2013).

One of the foundational feminist scholars on gender, nation, and citizenship, Yuval-Davis' work wrestles with the idea that the "natural" role of women is the to 
be the "biological and cultural reproducers of the nation" and that women's bodies represent "national boundaries" (1991; 1997). Similarly, Nagel observes that "national and sexual boundaries are mutually reinforcing" (2003: 141). Women's bodies become a national concern and citizenship becomes entangled with sexuality (Nagel, 2003). Reproductive rights are regulated by the state, who dictates population growth (Yuval-Davis, 1991). In developing countries, women's reproductive rights are dictated by developed nations, who use Third World regimes to implement racist policies to "stop overpopulation" (Wangari, 2002; Lopez, 1998). Women's bodies have also been viewed as sites to be conquered through rape, which is a common strategy at times of war (Mayer, 2004).

Substantial feminist work is situated at the intersections of gender, ethnicity, and nationalism. Within a nation, certain racialized bodies are excluded from the 'imagined community' and are not treated as 'full citizens'. Yuval-Davis points to the contradiction within the concept of citizenship: gender, ethnicity, class, etc. are not supposed to be of relevance to the status of citizenship (1997: 6), yet ethnic/racial minorities and women have "secondary access to state powers", hence are treated as second-class citizens (1991: 58). Secor's (2007) work on Kurdish women's political subjectivity highlights this contradiction, in which she shows how theoretically speaking, everybody who holds Turkish citizenship is considered equal, yet in practice Kurdish people are treated as second-class citizens and are subject to "the state of exception". 
While feminist scholars have queried women and the nation (Yuval-Davis, 1991; 1997) and the role of femininity in nation-building (Chatterjee, 1993), another avenue of research engages with gendered nationalist performances through a focus on masculinity (Mayer, 2000; Enloe, 2013; Faria, 2013). Understanding the construction of masculinity is crucial to understanding the construction of femininity. Mayer's work examines the interconnections between nationalism and masculinity in Zionism, unraveling the direct association of feminist scholarship with women and femininity. Similarly, through a focus on male participants at a Sudanese beauty pageant, Faria illustrates how the pageant becomes a site where Sudanese nationalism is scripted through the masculinized performances of its male audience. Enloe's (2013) recent work on the Egyptian police force, analyzes women's experiences with the state's masculinized security forces, such as the sexual harassment of female activists.

Clothing also plays an important role in the nationalist discourse. Within the colonial context, Fanon's (1967) earlier work on the unveiling of Algerian women demonstrates how women's way of clothing has greater implications on the nation. Women as "moral citizens" and women as "modern citizens" are expected to act and dress in a certain way. Fluri (2009) investigates "feminine corporeal modernity" through Western representations of Afghan women, while Gokariksel and Secor (2010) explore "moral citizenship" through the Turkish veiling fashion. The veil becomes a part of the "embodied performance of identity" not only in a moral fashion, but also within the context of political Islam. Women participating in the 
veiling practice become active participants in the ongoing struggle over the (re)definition of citizenship on the grounds of femininity and morality. Yilmaz (2013) provides outstanding archival work on the social experiences with the early republican reforms in Turkey, by looking at the reforms around men's Hat Law and women's veiling, which she frames as "dressing the nation". Through specific narratives, Yilmaz investigates how women had to simultaneously "accommodate the demands of the authoritarian state and male-dominant culture" (2013: 16). Through controlling what women wore and how they behaved in public, women were subject to religious orders and certain standards of national morality.

\section{Multi-scalar Analysis}

Feminist scholars have argued that focusing primarily on mega actors such as the state, government, and international organizations on national, international, and global scales misses the everyday and mundane exercises of power and important political acts (Sharp, ed. Staeheli, et al., 2004). Meta-narratives of the national and global, cast political subjects as passive recipients of social, political and economic processes. Through their focus on the body, the household, and the local, feminist political geographers have sought to demonstrate that scales are not separate, but mutually constituted. This multi-scalar approach has been coined by feminist geographers as "the global intimate" (Pratt \& Rosner, 2006; Mountz \& Hyndman, 2006). The global intimate approach shows how the local informs the global and vice versa. 
While feminist scholars have treated the body as the smallest scale, as seen in the scholarship on embodiment, the household has also been an important site in feminist theorizing (Massey, 1994; McDowell, 1999; Pratt, 2004). National and global scripts are reproduced within the household, making it a fundamental site for the initial constructions of political subjectivity. For example, McDowell shows how women's main contribution to society has been historically defined as "keeping house", while men's contributions have been located within social, political and economic spheres (1999: 71). This perception has locked women into the domestic sphere across the globe. Through her focus on Canadian households, Pratt (2004) shows the multiple political positions Filipina domestic workers hold and how they negotiate between these positions.

Communities hold importance for feminist geographers, who use this scale to look at women's political participation and organization within their communities. McDowell defines community as a place at an "intermediate scale: a locality or residential area within a city" (1999: 97). She explains how communities are used to designate "small-scale and spatially bounded area within which it is assumed that the population, or part of it, has certain characteristics in common that ties it together" (1999: 100). Secor's (2001) study on lower-class migrant communities in Istanbul reveals the economic struggles and social experiences of Kurdish women at the scale of everyday life and how these experiences shape Kurdish women's political subjectivity. 
While a large portion of feminist political scholarship investigates the body, the household, and the community, this does not mean that feminist scholars are not concerned with global and transnational processes. Transnational feminism emerged in the 1980s as a response to 'global feminism', the latter promoting a universal sisterhood (Fernandes, 2013). As opposed to a feminism that ignored social, racial, economic differences between women, transnational feminism promotes a feminist practice that recognizes the varied experiences of women within different geographical and historical contexts. Mohanty upholds a women's solidarity that transgresses borders (2003: 3). Through focusing on the relationships and exchanges between Diaspora communities and their home countries, scholars such as Grewal and Gopinath explore the 'feedback effect' of certain transnational developments. For example, Gopinath (2010) disrupts the essentialized Diasporic and national identities by examining the controversial Indian movie 'Fire', its greater implications within the transnational Indian communities, and how it has been received at 'home'. Grewal (1998) warns against the romanticization and naïve celebration of NGOs and grassroots organizations, as they also are capable to depicting the West as the rescuer of the Third World. Grewal points out the blindness of certain Western human rights advocates, as they tend to focus on women's abuses and human rights violations 'over there', but overlook the very same issues at 'home'. 


\section{Reconfiguring Formal/Informal Politics}

Traditional political geography has primarily focused on formal spaces such as the municipality, the government, the voting office, and legislation. 'Informal' spaces such as home, community, the playground, and women's gatherings were not considered 'political' (Fincher, ed. Staeheli et al., 2004). Feminist political scholars started questioning what counts as 'political'. Did one need to be involved in formal politics or be visible in the public sphere to be considered 'political'? Considering how women and marginalized groups have limited access to the public/formal/political spheres, feminist scholars argued that focusing on these spheres overlooked transformative acts in other spaces.

The popular binaries of formal/informal, private/public, and political/apolitical marginalize women's everyday political acts (Cope, ed. Staeheli, et al., 2004). Women have historically been assigned to the private sphere as apolitical subjects. When they engaged in political acts, they were considered 'informal'. Feminist geographers have demonstrated how these categories are not separate but co-dependant and have highlighted the social construction of these dualisms (Fincher, ed. Staeheli, et al., 2004). Fincher queries the 'formal' workplace and shows that they are sites of gendered political practice. Workplaces shape political subjectivity through the powerful operations of race, gender, class, and sexuality. Fincher further investigates women's activism within the community and against the state through shifting her lens on Panelli's (2001) work on women's organizing in rural Australia and Anderson \& Jacobs' (1999) work on Aboriginal 
women's activism against domestic violence. Fincher's work demonstrates how women's activism is not always directed against the state, but can also target gendered practices and injustices within their households and communities.

Further research on political activism investigates connections between 'informal' and 'formal' political acts. For example, Secor (2001) examines the daily political acts of lower and lower-middle class urban women in Istanbul and shows how their 'informal' acts translate into 'formal' politics through women's roles as "vote-gaining machines" for Islamist political parties. These women enter houses in various lower class neighborhoods to collect data and secure votes in return for incentives. They also build "informal female networks" of mutual aid, which act as grassroots social service providers in places where the government does not reach. This can be read as women's mobilization for social justice. Similarly, Cope shows how 'formal' politics influences 'informal' politics, and vice versa, through the example of factory workers' mobilization at various localities around the world (ed. Staeheli, et al., 2004). She also points out that women's political activism is not necessarily about women and gender issues, but also about issues of basic human rights, social justice, and daily survival.

Feminist scholars have also made visible feminist political activism in the public sphere in the Global South. Fluri (2008) unsettles the image of Afghanistan and the 'passive' Afghan woman by locating their political agency. Through studying RAWA, a feminist political organization, Fluri draws on women's counterpatriarchal resistance within a cultural framework that is unique to Afghanistan. 
Fluri conveys how important it is not to romanticize women's political and social movements within a Western perspective, but try to understand them within their own geographical and historical framework. Yet another example of feminist nationbuilding through women's activism is provided by Erickson and Faria's (2011) work on SSWEN, a South Sudanese women's organization. Through a transnational feminist framework, the authors highlight the ways in which "female practices of citizenship and activism are articulated and enacted" in the case of the South Sudanese Diasporic community (2011: 2). Finally, feminist scholar Caglayan (2008) brings into light the involvement of Kurdish women within the Kurdish nationalist movement through armed struggle, becoming mayors and deputies, and taking seats in the Turkish parliament. She stresses the fact that these women were not urban, professional, educated women and received little attention in social sciences. She locates Kurdish women's agency at the intersections of nationalism, ethnicity, gender, and 'formal' politics. She maintains a critical lens and does not automatically associate women's political participation with their emancipation, but remains hopeful that through their increased political activism, Kurdish women will continue to challenge Kurdish patriarchy from within.

\subsubsection{On Feminist Geopolitics}

Feminist geopolitics traces a long path, paved by traditional political geography, critical geopolitics, and feminist political geography. Each of these geographical subfields has theorized the state, nation, citizenship, territoriality, and sovereignty, with the newer subfields refining the critical lens of the former. While 
critical geopolitics refined the political geographical lens by paying attention to everyday exercises of power, using a multi-scalar analysis, critiquing Westocentricism, and engaging in more empirical research (Ó Tuathail, 1996; Slater, 2004; Agnew, 2006; Oslender, 2009; Gregory, 2010; Dittmer, 2013), it lacked reflexivity and remained short of incorporating important questions around gender, race, and sexuality.

A subfield of feminist political geography, feminist geopolitics emerged in the early 2000s, through the foundational theorizations by Secor (2001), Dowler \& Sharp (2001), Hyndman (2004), and Gilmartin \& Kofman (ed. Staeheli, et al., 2004). These feminist scholars critique the domination of critical geopolitics by white male academics, who do not "disclose their own location" (Dowler \& Sharp, 2001: 167) and render critical geopolitics as a "disembodied critical practice" (Hyndman, 2004). Feminist geopolitics is an "embodied position where different scales of analysis come together" and highlights the importance of the researcher's situated knowledge and reflexivity (Dowler \& Sharp, 2001: 167). It is a practice that aims to reveal women's agency, which is hidden from the traditional gaze of geopolitics. Through a focus on the everyday experiences of the marginalized, feminist geopolitics makes their experiences visible and rewrites them as active citizens. As the finest scale, the human body is both the subject and object of feminist geopolitics, through which embodied power relations can be analyzed (Hyndman, 2004). 
Critical geopolitics has come a long way since mainstream political geography and geopolitics, venturing on deconstructing power structures, paying attention to smaller scales, and even utilizing a corporeal and gendered analysis to a limited extent. While feminist geopolitical scholars have built upon the intellectual advances of critical geopolitics, they have critiqued it in three major ways: (a) its disembodied practice, (b) inability to move beyond deconstruction, and (c) lack of gendered analysis.

\section{What does a Feminist Geopolitics Look Like?}

Feminist geopolitics is a relatively new subfield, with small but growing literature. While much of its methodologies are rooted in the intersection of feminist political geography and critical geopolitics, it is also influenced by the theorizations of transnational feminism and feminist international relations (Hyndman, 2004). So, what does a feminist geopolitics look like?

As many feminist scholars have argued, feminism needs to be continuously "emptied out of its singular focus on woman, and possibly rethought around a broader critique of the production of social difference and the multiple exclusions enacted by dominant groups and institutions." (Pratt, 2004: 84). Feminist geopolitics assumes a lens through which everyday experiences of not only women, but also the disenfranchised can be made more visible (Dowler \& Sharp, 2001: 169). Feminist geopolitics does not abandon scale in exchange for a "flat ontology" (Marston, Jones, and Woodward, 2005). Analysis on multiple scales is key; the body, 
home, community, and nation all are important sites of performance and cannot be considered separate. Denying the existence of social, political, and cultural constructions, such as scales and binaries, is naïve, because these constructions continue to have material effects. Feminist geopolitics acknowledges this reality and tries to dismantle hierarchies through showing how they are co-constituted.

Feminist geopolitics strives to produce knowledge that is grounded in the everyday experiences through fieldwork and participatory research, but not as a "naïve return to the field" (Sharp, ed. Staeheli, et al., 2004: 97). Sharp warns of "choosing" an exoticized group to study without a particular political or social commitment to the group. Reflexivity is crucial as a researcher; being aware of one's political stand, recognizing one's ambivalent position within and outside the community (Sharp, ed. Staeheli, et al., 2004: 98), and being mindful of one's insider/outsider position (Mohammad, ed. Limb \& Dwyer, 2001) are all important elements of conducting feminist research.

Scholars of feminist geopolitics strive to move beyond a deconstructivist approach; they try to envision and lay out alternative possibilities and positive politics. These scholars bring in an intersectional analysis that considers the entanglements of race, ethnicity, religion, sexuality, and gender and rewrite women and the marginalized as "multi-layered citizens" who have agency (Yuval-Davis, 1999). 


\section{Applying Feminist Geopolitics to Antakya and the Archives}

My research contributes to feminist geopolitical knowledge in two major ways; by reconfiguring Arab Alawite women as agentive subjects, and by offering an alternative interpretation of Islam and its practice by women. In the Turkish nationalist imaginary, Arabs are considered "backwards" and "oppressive". This was a perception I witnessed time and again, especially by Turkish Sunni men, who described Arab Alawite women as "oppressed" and "submissive". This stems from the historical juxtaposition of Turks as 'progressive' and 'modern', and Arabs as 'backwards' and 'traditional'. By locating Alawite women's agency, my aim is to contribute to the dismantling of this perception.

Secondly, most literature on Muslim women has been within the framework of Sunni Islam and to a certain degree Shia Islam. With the exception of Akkaya's recent book (2014) on Turkish/Kurdish Alevi and Arab Alawite women, there is practically no literature that explores the religious, social, and political construction of Arab Alawite women. Through my research, I will not only expand knowledge on the various interpretations and embodied performances of Islam, but also work towards a more positive reconstruction of Muslim women.

I find feminist geopolitics a useful theoretical lens for my archival research, because of its sensitivity to gendered language, critiques of macro-analyses of the state and dominant forms of power, and insistence on hearing the stories of the historically silenced and locating agency in places often overlooked. Feminist 
scholars have produced expansive theoretical and empirical scholarship on the nation, state, gender and citizenship (Yuval-Davis, 1993; Enloe, 2004; Fluri, 2006, 2008; Faria, 2013). This rich body of work expands the understanding on how the nation-building project is a patriarchal process and how "nationalism is always gendered" (McClintock, 1997), in showing how the state draws on masculinities and femininities to script a new nation (Faria, 2013). This particular feminist perspective on nation-building proves to be particularly useful for the national script of Antakya's annexation, because of the gendered symbolism used in the construction of the narrative.

The incorporation of oral history in reframing the post-colonial condition proves to enhance our understanding of the past and present. History has been consciously used to pass on activist knowledge to a new generation through public discussions about the past and by making intimate conversations about the past into public documents. Oral history, a formalized practice with roots in the academy, thereby makes the power of history accessible to grassroots social movements. (Starecheski, 2014).

\subsubsection{Postcolonial Engagements with Feminist Political Geography}

"The political priority for feminist geography is to embrace a postcolonial agenda wholeheartedly" (Laurie \& Calla, ed. Staeheli, et al., 2004: 99).

In the second half of the twentieth century, we see a rise in "subaltern knowledges", produced from the perspectives of 'Third World' scholars, in line with 
de-colonization and anti-colonialism movements. We also see a rise in feminist scholarship on the patriarchal state and gendered construction of citizenship and nationalism. Due to the intensified geopolitical events in the Middle East, scholarly interest in Islam and secularism has grown immensely, especially since the 1980s. Feminist and postcolonial scholars have queried the production of knowledge itself, considering much of the work within this realm has been Eurocentric and patriarchal (Sharp, 2003). These two fields of studies contested the concept of the "imagined universal individual" based on the white European male subject and offered alternative understandings of citizenship (Stepan, 2002).

\section{Colonialism/Orientalism and the Modern State}

According to John Agnew (2005), the idea that the world had to be divided into territories to be governed by states has been taken for granted, and for a long time, there was little interest in questioning this process within academia. He argues that the reason why the interest has peaked recently is due to the belief that "states no longer have the powers that once were vested in them" and to the expansion of global geopolitics beyond state-defined territory, towards a "new geography of power" (2005: 184). Since then, there has been a rising interest in the history of modern statehood, which for the most part focused on the emergence of the Western nation-state and its construction of the 'modern subject'. The European model of statehood and citizenship has been considered 'the norm'. The concept of a nation-state, where the nation and the state perfectly coincide and its people united by the same language is a Eurocentric idea, which is one of the reasons why there is 
an increasing disjuncture between state and nation in 'Third World' countries (Trouillot, 1990). Postcolonial scholars have criticized the Western understanding of statehood and citizenship and have urged for the re-conceptualization and retheorization of citizenship (Bhabha, 2004; Agamben, 2005; Isin, 2012).

Postcolonial scholarship on nationalism began by looking at the beginning of the $20^{\text {th }}$ century, when Asia and Africa witnessed a surge of counter-hegemonic movements and struggles for independence (Kelly \& Kaplan, 2004). Nationalism in forms of violent and nonviolent anti-colonialist and counter-hegemonic movements swept Asian and African colonial territories, taking advantage of the fighting between colonial powers. Nationalist movements driven by elites and peasants became a universal revolt against the West, while ideas of self-government and selfdetermination were quickly spreading (Barraclough, 2004). While Anderson (1983) described these movements as the "last wave of decolonization", Kelly \& Kaplan reframe these movements as "the beginning of a new world order" (2004: 131).

\section{Post-coloniality in the Middle East}

The creation of Middle Eastern states is a direct outcome of the colonial involvement in the region after the collapse of the Ottoman Empire. As is the case in other postcolonial regions, the borders imposed by colonial powers are contested continuously, at times with violent eruptions, such as Iraq/Syria and Israel/Palestine. While some might argue that Arab nationalism emerged as a counter-movement to colonial powers, Gerber (2004) believes that a sense of 
Arabism existed from the early Islamic period. He proposes a combination of two approaches, the modernist and the historical, to the study of nationalism in the Middle East. His study suggests that Middle Eastern nationalism wavers between country-based nationalisms, such as Syrian/Iraqi/Egyptian nationalism, and ethnic pan-Arabism (2004: 252). While he states that there is no necessary connection between language and nationalism, the Arabic language still played an important factor in pan-Arabism, which pitted the Arab nation against the Ottoman Turks.

The Palestinian-Israeli conflict has arguably gotten the most attention in scholarship on questions of Arab nationalism and statehood. Scholarly work includes historical research of the roots of the conflict (Tessler, 2009) and the intimate relationship between Islam and Arab national identity (Matthews, 2014). These works have not only looked at how the Palestinian nationalist movement and the Zionist movement emerged, but also underlined the role of colonial powers, specifically Britain and the United States, in determining the fate of the two nations.

Within a postcolonial framework, I regard Antakya as a territory that was colonized by modern Turkey. The annexation of Antakya from Syria in 1939, the construction of the province within the Turkish nationalist imaginary, assimilation policies of 'Sunnification' and 'Turkification' targeting Arab Alawites, and the Turkish settlement projects of the state hint towards a small-scale colonization. While Arab Alawites are not the only minority that experienced assimilation in Turkey, they remain as one of the least explored, compared to the Kurds and Turkish Alevis. 


\section{Feminist and Postcolonial Contributions}

According to Sharp (2003), the feminist and postcolonialist projects have similar goals, such as breaking binaries, moving away from essentialisms, embracing hybrid identities, and paying attention to operations of power, race, and gender. Scholars from both feminist and postcolonial studies have tried to apply these objectives to studying the state, nationalism and citizenship. While feminist scholars have transformed the abstract citizen by looking at embodiment (Longhurst, 1997; Butler, 1999; Nagel, 2003; McDowell, 1999; Fluri, 2009), postcolonial scholars have deconstructed Western understandings of citizenship and revealed subaltern knowledges (Fanon, 1967; Said, 1978; Chatterjee, 1993; Bhabha, 2004; Isin, 2012). At the intersection of feminist and postcolonial studies are postcolonial feminists, who examine the entanglements of gender, race, sexuality, and power (McClintock, 1997; Mohanty, 2003; Spivak, 2006; Stoler, 2010).

The feminist intervention demonstrated how race, ethnicity, gender, and sexuality shape citizens' experience within the nation and their treatment by the state. Yuval-Davis' (1999) concept of the "multi-layered citizen" is a useful way of thinking about the various identities and position a person holds and how they affect their citizenship. Citizenship works not only at the state level, but also at the scale of everyday life. Feminists have successfully linked the embodied citizen to the nationalist discourse on a greater scale, by showing how nationalist scripts are reproduced at the scale of the human body. Finally, feminist theorists highlighted the role of women in the nation-building process, as "biological and cultural 
reproducers of the nation" and how this role meant that women's bodies had to be policed by the patriarchal state (Yuval-Davis, 1996).

The main intervention of postcolonial scholars has been the deconstruction of 'modernity' and Western models of statehood and citizenship, by making visible alternative understandings. Postcolonial studies show how colonialism has influenced the way we view the world, examine the current power relations of the Global South-North, and cultivate "our abilities to imagine possibilities for change" (Laurie \& Calla, ed. Staeheli, et al., 2004: 100). Postcolonial theory has also challenged binaries and the politics of opposition, such as the Oriental/Occidental, by showing how anti-colonial and liberation movements can "act to reinforce both colonial and patriarchal power" (Sharp, 2003: 62). For example, Chatterjee (1993) shows how the politics of nationalism in postcolonial India tended to glorify India's past, defend traditionalism, and construct a binary of spiritual/material, in which India represented spiritual culture. In order to overcome this binary logic, postcolonial theorists have put forth the notion of hybridity, a fluid concept that celebrates impurity (Bhabha, 2004). Through re-theorizing the nation as fluid, always becoming, and embodying hybrid notions, postcolonialism has transformed the hegemonic Western understandings of the state and nation.

A postcolonial analysis helps view Antakya as a conflicted territory, whose fate was determined with the influence of Western powers, as opposed to the takenfor-granted national narrative of "Hatay has always been Turkish". Furthermore, a postcolonial analysis serves to better capture the events that took place during the 
annexation period. Finally, deconstructing Antakya's annexation script brings to light the attempted erasure of the region's Arab Alawites and its effects on their identity formation.

\subsection{Road Map}

In order to understand the rise of women's political consciousness among the Arab Alawite community in Antakya, it is pivotal to know the roots of politicization in the region, within a historical and cultural context. With this intention in mind I venture into the annexation period of Antakya in 1939, to lay out the groundwork that led to competing nationalisms, ethnic and religious tensions, and later on leftist movements. Therefore, I begin with Chapter 2: Project Motherland: Antakya's Annexation in 1939 and its Implications for its Arab Alawite Population where I investigate the "Hatay Issue" during the Republican Era, in the aftermath of World War I and the collapse of the Ottoman Empire. In this chapter, I focus on territoriality, the Turkish nation-building project, and how it shaped the Arab Alawite collective memory and their experience as an ethno-religious minority in Turkey. For my critical discourse analysis, I rely on archival documents collected from the State Archives in Ankara, Turkey. I also incorporate oral historical accounts from mainly elderly Arab Alawites, some Arab Christians and some Turkish/Arab Sunnis who either lived during the annexation period or are well acquainted with the events at the time. I discuss the systematic efforts for the cultural erasure of Arab Alawites under the Turkish state and highlight the gendered language found in the Turkish nationalist imaginary. 
Arab Alawite women's politicization proved to be inseparable from their religious experience and the gender dynamics within the community. Therefore, in Chapter 3: Arab Alawite Women's Religious Experience and the Self-acclaimed 'accidental' Benefit of Religious Exclusion I discuss the exclusion of Alawite women from certain religious spaces and how they cope with such restrictions. Drawing from in-depth interviews, focus groups and participant observation, I sketch out Alawite women's religious identity formation and religious experience. Alawite women often association their political consciousness, social freedom and economic empowerment to their faith, which allows them to think more independently and critically, as I was told.

Leading up to the 1980 coup d'état, various leftist, socialist, and communist groups and social movements sprung up in Turkey in the 1960s and 1970s. Marginalized groups, for the most part, aligned themselves with leftist movements, as did many Arab Alawites. In Chapter 4: Process of Politicization in Antakya: Arab Alawite Identity, Leftist Movements, and Women's Involvement I explore the nature of such political movements and what made them attractive to minorities such as the Alawites. Antakya was a stronghold for leftist organizations, which were more inclusive of women, thus providing a steppingstone for women's politicization and feminist organizing. Important gender dynamics come out through the narratives of Alawite women who were involved with leftist and socialist organizations during that era. In this chapter, I also investigate the so-called "Arab 
Alawite awakening”, instigated by the ongoing Syrian Conflict and the Gezi Park protests during summer 2013.

Alawite women often constructed themselves as being "more advanced and progressive" compared to Sunni women. Chapter 5: "We are always one step ahead": The Identity Construction of Arab Alawite Women delves into this notion and identifies certain cultural practices that are contributing factors. Some of the factors I discuss are embodied performances of identity, socio-economic opportunities, and male labor migration. I also dedicate a comprehensive section on ethnosexual frontiers and crossings, using Joane Nagel's concepts of ethnicity, sexuality and collective imaginings. I discuss the construction of Arab Alawite women as the 'promiscuous Other', who is religiously and sexually deviant in the Sunni imagination.

\section{Finally, Chapter 6: Arab Alawite Women as Agents of Social and Political}

Change deeply engages with feminist geopolitical discourse in investigating the various 'formal' and 'informal' political acts of Alawite women. I pay attention to the individual as well as organized efforts of women in resisting and interrupting male hegemony and statist oppression. I also discuss feminist critiques of the Left, the roots of feminist movement in Antakya, and the prospects for an Arab Alawite women's movement. In this chapter, many themes from previous chapters come full circle, highlighting both the perseverance and resilience of Arab Alawite women. 
"Your research is important, because it gathers the perspectives, experiences and ideas of many people and it will be a concrete source [for us]. So, I could just pick it up and see what my people think about certain issues, instead of talking to forty women and twenty sheikhs. There is a woman who has done this research, contacted people, touched them, organized the data, and created a source. So, by reading one book, I will have reached one hundred people." Songul, lawyer, feminist activist, and politician from Samandag, Antakya 


\section{CHAPTER 2: Project Motherland: Antakya's Annexation in 1939 and its Implications for its Arab Alawite Population}

“...we too suffered through this, because the people who witnessed this catastrophe were Turks. Just like the aching a mother feels in her breasts when hearing the wailing of her baby asking to be fed, that is how the cries of the stricken Turkish children of Hatay, separated from their motherland, have caused pain in every Turk's heart."2

This chapter primarily addresses territory, nationalism, and the postcolonial condition (Sharp, 2003; Said 1978; Yuval-Davis, 1997; Fanon, 1994) in Turkey, particularly Antakya. Through a feminist geopolitical and postcolonial lens, I detangle some of the events surrounding the Turkish annexation of Antakya in 1939 from the French Mandate of Syria, and the ramifications for its Arab Alawite population. The fate of Antakya, and of its Arab Alawite population, was determined by Turkey and France (who was occupying Syria at the time), with little to no voice given to its local actors or the Syrian 'nation'. On comparing the mandate system to colonialism, Sluglett writes, "The framers of the mandate system thought they were improving on colonialism, but given the fact that they all had 'conventional' colonial empires of their own, and given the poverty of the regulatory machinery, the outcome was not all that different from the colonized countries" (2014: 225). In line with this statement, I remain critical of not only the so-called 'mandate system' and

2 Public talk by Cumhuriyet Halk Partisi (CHP) political party official in Corum, 23 July 1939, 490-01-21-106-1, page 124, Celebrations for the Anniversary of Hatay's Liberation, Prime Ministry State Archives- Republican Era, Ankara, Turkey 
Western involvement in the region, but also the premise of 'independence' and selfgovernance in post-Ottoman Middle East.

The chapter is largely based on my archival research conducted at the State Archives in Ankara, Turkey in December, 2013 and June 2016. Drawing on a wide range of archived materials I collected, including telegraphs, public talks, letters, government declarations, poems, public and private statements, it became clear to me that a framing of Antakya as a postcolonial region offers a novel analysis of the annexation. Such postcolonial analysis not only brings local voices to the forefront, but also challenges the annexation narrative scripted by the Turkish state. As Edward Said said, "human history is made by human beings, and [s]ince the struggle for control over territory is part of that history, so too is the struggle over historical and social meaning" (2003: 331-2 in Slater, 2004: 3). Thus, challenging the takenfor-granted historical narratives and social meanings produced during the annexation period, and questioning the construction of Antakya in the national imaginary is central to a postcolonial analysis.

I begin by highlighting the power of oral history. In a political climate that is defined by strong Turkish nationalism, stories from the ground bring in alternative, often ignored or suppressed, perspectives on the annexation process, and on what it means to be an Arab in Turkey. In this section, I also discuss the construction of Arab-ness in the Turkish nationalist imaginary and how it has shaped the Arab Alawite experience by labeling them as 'the Other'. Leading up to the annexation and in the aftermath, there was an outburst of strong Turkish nationalist sentiments, 
which aimed to redefine Antakya as a historically Turkish territory and the Arab Alawites as authentic Turks who had forgotten their ethnic heritage. There were efforts on the national and local level to religiously and ethnically assimilate the Arab Alawite population, which continue in different forms today. I use a feminist/ geopolitical lens to investigate such processes. In the following section, I make a case for Antakya as a postcolonial region, whose fate was determined by France and Turkey, without the input of Syria. The handing over of 'the Sanjak of Alexandretta' (Antakya/Hatay) to Turkey was in fact "in contradiction to the wishes of the majority of the population and to the obligations France had assumed towards Syria as the mandatory power" (Sluglett, 2014: 225). Moving on, I showcase my findings on the state's assimilation politics through focusing on the re-naming of Antakya, language politics, and the incitement of intermarriage. In the last section, I analyze the gendered language found in the archival documents regarding Antakya's annexation. The strong (and troubling) gendered language used by Turkish actors when describing 'Hatay', underline how nation-building is a patriarchal and masculinist project, which relies on representations of femininity and infancy to legitimize its actions.

\section{1. 'Whose Story Counts?': The Power of Oral History}

"Dear friends, when we look at the history of Turkey, Arabs seems as if they came here on parachutes. You would think that the wind has swept these people until here. The truth is far from that. The geography in which the Arabs of Turkey live, is in fact their motherland, and they have a profound history. They also have strong ties with all Arab populations of the Middle East. Unfortunately, the official history tells us a certain narrative so that we will no longer know who we are. This narrative tries to disconnect us from our roots. It 
gives us a place to live, but leaves us without a homeland. It never tells us the full reality of the annexation period. It does not recognize our pains, our angers, but it recites this vain story based on lies. It tells us about the people who have founded the Hatay State, but it does not tell us about Cemil Hayek ${ }^{3}$ or Zeki Arsuzi4." - Dr. Selim Matkap

This excerpt is from the opening talk of the Research Institute for the Middle Eastern Arab Peoples (Arab Institute) in June 2015, given by Dr. Selim Matkap, the institute's president. This statement neatly summarizes the plight of the Arab Alawites of Turkey, in terms of their history, and their stance against the Turkish nationalist narrative of the annexation period. While national and local archives can reveal, or hide (Stoler, 2010), important details from the past, oral history helps expose topics that have been ignored and "present diversified perspectives on the past" (Sangster, 1994: 6). As such, the official and bureaucratic historical accounts have left out oral histories, and thus dismissed the way communities living in Antakya have experienced the annexation period. While oral history can also reveal/hide, oral accounts complement the archives by tuning into voices that are commonly silenced or left out.

\footnotetext{
${ }^{3}$ A local Arab Alawite hero from Samandag, who revolted against the French during the French occupation period.

${ }^{4}$ An Arab Alawite from Antakya, who was an influential Arab nationalist and philosopher. He moved to Syria after the annexation and became one of the founders of the Baath Party.
} 
During an interview for YES! Magazine, executive director of Voice of Witness ${ }^{5}$ mimi lok says,

"The views of the situation of the people who were most closely affected by it are often the ones who are least heard from. When you don't have that perspective, you're missing a big chunk of understanding about that particular issue. You can't look at it from the top down; it has to be from the bottom up. Historically, oral history has been considered one of the more egalitarian forms of storytelling because you have to preserve the integrity of what someone said and how they said it. It's a really powerful way to counteract the dominant narrative around an issue or situation."

The oral history project on Antakya's annexation period, executed by the Arab Institute, aims to do just that. The first published report of the oral history project indicates, "as the Research Institute for the Middle Eastern Arab Peoples, we probed into the relationships of peoples of the Sanjak of Alexandretta, to Turkish land, to the state and with each other, and their lifestyles during the time of the French mandate" (2016: 1). Through the tales of the men and women who have either experienced the era first-hand or have substantial information from their parents, the project proves to be a first of its kind.

Mahir, one of the founding members of the Arab Institute, told me that one of the main reasons he wanted to join the institute was to increase his knowledge on the history of this society, and this geography, even if it meant finding out that his grandfather was a traitor, which was a potential outcome he was ready to face. He adds, "everybody is writing about us except for us; they are [re]producing

\footnotetext{
${ }^{5}$ Voice of Witness (VOW) is a non-profit that promotes human rights and dignity by amplifying the voices of people impacted by injustice.
} 
imaginations". He is adamant that the 'real history' of this region will surface sooner or later, as the 'official history' of the region is based on "a heap of fabrications".

Mahir's grandfather was in an organization that wanted Hatay to remain an independent state, which was up for vote during the 1939 referendum. This organization was led by Tukhani, a rich agha ${ }^{6}$ from Harbiye, who armed the local Arab Alawite population that ascribed to Arab nationalism. According to Mahir, during the annexation period Turkish forces armed Turkmen villages in the vicinity, hoping to start conflict between them and Arab Alawites. The Turkmens formed paramilitary groups to coerce Alawites into leaving their land. Some Alawite sheikhs, however, were in favor of joining Turkey. Mahir tells me that a certain group of sheikhs invited his grandfather for dinner and poisoned him due to his affiliation with the Tukhani movement. Mahir could not find any information pertaining that period, but learned there was a local archive that had 'coincidentally' burned down and only pro-Turkish documents and newspapers survived.

During one of my focus groups, Bilge, a high school literature teacher in Serinyol, frames Antakya's annexation as the beginning of a cultural shift. She sees the annexation period as a much-needed area of study, particularly the various Arab nationalist movements at the time, which have been completely drowned out by Turkish nationalist narratives. She believes the oral history project carried out by the institute is a response to this need. She complained, "who recounts and writes

\footnotetext{
${ }^{6}$ Aghas are local landowners, who employ peasant populations to work on their fields and who practically serve as the village chief.
} 
Hatay's history? The Turks. Arab Alawite poets, stories, lullabies, experiences aren't recited, and they need to be recognized".

One of the oral history project volunteers, Melike, was a participant at the "State Relations and Secularism" workshop during the Arab Alawism Conference. She found it quite surprising that even though everyone in the room was Arab Alawite, there were contesting views on topics like Ataturk or the referendum in 1939. She said:

"There were people who liked Ataturk and those who did not. There were those who say there was a referendum, but also those who say there wasn't. Most of the people we interviewed for the oral history project said there wasn't [a referendum]. If there was, it was the elite people who voted. I don't know which is right. We went to Harbiye and Serinyol for the oral history project."

Even within the Alawite community, there is not one unified story. There is at times, however, a popular narrative of victimization, which Necmi, a local musician and elementary school teacher, takes issue with. As part of the audience, he critiqued the Arab Alawism Conference:

"At the conference, the main theme was victimization, how we were massacred etc. This is also the case for Anatolian Alevis, and it's the truth, alright, but there are positive things about us, too. We are face to face with losing our culture due to hegemonic powers. This is why we need fresh production [of cultural values]."

Necmi thinks the narrative of 'Arab Alawites as victims' is old news. "Alawites have not just been oppressed or massacred; there is so much more to our history and 
culture," he said. He referred to Arab Alawite 'agency' as the other side of the coin, which should also be put under the spotlight. He complained how the Alawite community has not focused enough on the positive aspects of their culture. He further argued:

“We listened to Fayruz", but we didn't pay attention to our own gems. Within Arab Alawite events, the main theme is always victimization, or what Arab Alawism is. It's always the same. Movies and skits confined to the same thing, based on cheap humor or victimization."

Necmi is active in the production of 'fresh' cultural material. He writes and composes songs, is involved in documentary films on various cultural aspects of the Alawite community, and is one of the last people who continue the fennen ${ }^{8}$ tradition. $^{-}$ He is dedicated to preserving their cultural heritage through religion, language and music, and continuously finds new ways in doing so. He is a strong believer in locating history in poems, songs, lullabies, and stories dating back 100-150 years, and invents novel techniques to pass it onto coming generations.

But Necmi is neither the first nor the only one to attempt to keep Arab Alawite culture alive. There are Arabic music choirs, theatres, documentaries, short films, magazines, and a plethora of other initiatives within the Alawite community in Antakya. There are also the less 'public' or 'formal' initiatives, such as private home gatherings that include singing folk songs, sharing stories, and cooking traditional

${ }^{7}$ A famous Lebanese singer, very popular among Arab societies around the world. ${ }^{8}$ Arabic poet and singer of folklore. 
dishes, such as seen in Figure 2.1 below. A group of friends who know each other through an Arabic choir are celebrating Ras el Seni, the Arab Alawite New Year, by playing folk songs, singing in Arabic, and eating traditional dishes. In feminist geography, these acts are read as resistance to the dominant culture, especially in the Diaspora (Faria, 2014).

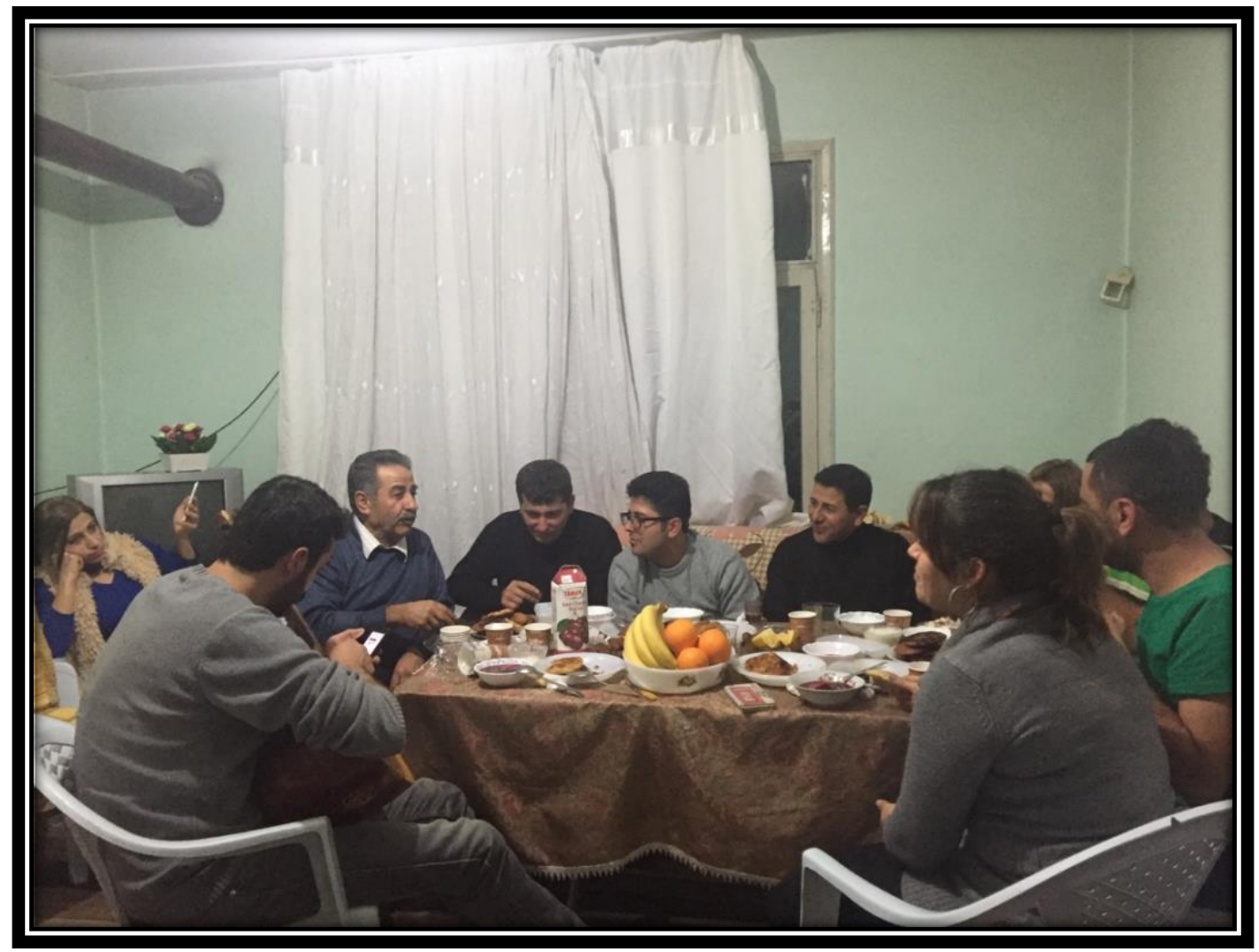

Figure 2.1. A gathering of friends at a private home while playing/singing Arabic songs and eating traditional food during Ras el Seni, Arab Alawite New Year (January 14, 2016)

Slowly but surely, Arab Alawites are reclaiming their history through initiatives such as the oral history project by the Research Institute and the extensive works of 'insiders' such as Mertcan (2014) and Duman (2016). While the 
archives give us one side of the story narrated by Turkish nationalists, oral accounts from Antakya give us another version of what happened during the annexation era. While both accounts often clash with one another, juxtaposing them reifies that nation-building is only possible by the erasure of certain identities/events/ pushbacks and that, as I will discuss in the last section of this chapter, it is always gendered.

\subsection{Re-framing Antakya as a Postcolonial Region}

In order to understand the collective memory and consciousness of Arab

Alawites in Antakya, we must reframe and reconfigure the annexation process, as it marked the beginning of a cultural shift for Alawites. Contrary to the taken-forgranted national narrative of "Hatay has always been Turkish", Antakya was a conflicted territory, whose fate was determined with the influence of Western powers. A postcolonial analysis serves to better capture the events that took place during the annexation period and deconstructs Antakya's annexation script. It does so by bringing to light the attempted erasure of Arab Alawite identity and its consequences on their identity formation today.

\section{The Role of France in the Annexation Process}

When history is written, it is often written by the victor, colonizer, hegemonic group or oppressor in any given context (McClintock, Mufti \& Shohat, 1997). This process works best when marginalized groups' voices are silenced. Stories that are told in the official archives often glorify the state and vilify/silence 
any opposition and resistance to the nation-building project. This is certainly the case for Antakya's annexation and its Arab Alawite population, as it appears in the Turkish state archives.

To begin with, what renders Antakya 'postcolonial', among other factors, is the fact that France and Turkey were the principal decision-makers in its annexation process, even though the territory 'belonged' to the Syrian Mandate (Sluglett, 2014). The involvement of France was key in determining the fate of Antakya, who at first was not willing to negotiate with Turkey. France had concluded in 1921 that "Antakya is a part of Syria and any discussions on this matter can be done with Syrian delegates" ${ }^{\prime}$. The relationship between France and Turkey became tense during this period. For example, a news clip from the French newspaper "La Republique” in 1937 reads, "France has been Turkey’s friend since 1535. The France - Syria treaty immediately produced a mandate issue, upon which the relations between Paris and Ankara became tense. We went backwards"10.

The archival records indicate that Turkey and France opened negotiations on Antakya in the 1930s. In 1937, "finally, the second round of discussions between

\footnotetext{
${ }^{9}$ Public talk by Dr. Cemal Alper, 23 July 1939, 490-01-21-106-1, page 184, Celebrations for the Anniversary of Hatay's Liberation, Prime Ministry State Archives- Republican Era, Ankara, Turkey

${ }^{10}$ Publication by the Turkish Press General Directorate, 11 December 1937, 030-10222-501, page 22, Prime Ministry State Archives- Republican Era, Ankara, Turkey
} 
Turkish and French delegates began in Geneva"11 and "as a result of discussions with France, it was concluded that Hatay would be annexed by the motherland unconditionally"12. Such statements were abundant during the nationwide celebrations of Hatay's annexation in 1939. One statement reads, "This piece of nation, which has been separated from us since 1918, was reunited with us as a result of an agreement reached with France"13. This specific statement further reads, “by signing Hatay's annexation by the motherland, which could not have been stayed separate from the Turkish nation, France has won over the friendship of a noble nation such as the Turkish nation"14. Yet another speech recites, "The France from 20 years ago only won over our friendship today by accepting our wish"15. One last quote reads, “This victory has been won by the great French Republic's respect

${ }^{11}$ Public talk by Dr. Cemal Alper, 23 July 1939, 490-01-21-106-1, page 186, Celebrations for the Anniversary of Hatay's Liberation, Prime Ministry State Archives- Republican Era, Ankara, Turkey

${ }^{12}$ Public talk by Dr. Cemal Alper, 23 July 1939, 490-01-21-106-1, page 187, Celebrations for the Anniversary of Hatay's Liberation, Prime Ministry State Archives- Republican Era, Ankara, Turkey

${ }^{13}$ Public talk by Basri Tozun, 23 July 1939, 490-01-21-106-1, page 42, Celebrations for the Anniversary of Hatay's Liberation, Prime Ministry State Archives- Republican Era, Ankara, Turkey

${ }^{14}$ Public talk by Basri Tozun, 23 July 1939, 490-01-21-106-1, page 43, Celebrations for the Anniversary of Hatay's Liberation, Prime Ministry State Archives- Republican Era, Ankara, Turkey

${ }^{15}$ Public talk by Fethi Arik, 23 July 1939, 490-01-21-106-1, page 83, Celebrations for the Anniversary of Hatay's Liberation, Prime Ministry State Archives- Republican Era, Ankara, Turkey 
and sympathy paid towards loyal friendship of the great Turkish Republic..."16. In short, Antakya's fate was determined through a deal struck between France and Turkey, without involving Syria or the local population, except for the fraught referendum.

The Turkish state held a referendum in Antakya in 1939, in which people voted on whether to remain as the "Hatay State" or become part of Turkey (Mertcan, 2014; Duman, 2016). As a result of the popular referendum, Turkey annexed Antakya. However, the referendum was questionable, not only because the state increased the local Turkish population through new settlements, who would vote in their favor, but also because many Arab Alawites (second largest population in the region) were not notified of such referendum, hence did not cast in their vote. It is important to note, however, that the resettlements of Sunni Turkmen tribes in the area dates back to the Ottoman era. Duman writes that in the second half of the $19^{\text {th }}$ century, the Ottoman state did indeed resettle Turkmen tribes in the Amik Plain, which used to be a lake and was drained (2016: 48). Also, at the time the Arab populations of the region did not speak Turkish, but discussions of the referendum were in Turkish. This translated into major lack of knowledge and awareness among the Arab communities. While working on the Arab Institute's oral history project, we interviewed older members of the Arab Alawite, Arab Sunni, Armenian, Arab

\footnotetext{
${ }^{16}$ Public talk by Fethi Arik, 23 July 1939, 490-01-21-106-1, page 84, Celebrations for the Anniversary of Hatay's Liberation, Prime Ministry State Archives- Republican Era, Ankara, Turkey
} 
Christian and Turkish communities. The majority of the non-Turkish interviewees did not recall a referendum at all.

Taking a look at the events unfolding at the time will illuminate the issue even further. When Turkey raised the "Hatay Issue" at the League of Nations in 1937, it was the dawn of World War II. France wanted to keep Turkey 'satisfied' and maintain them on their side. They were afraid of a repeat of World War I, during which the Turks had sided with the Germans, thus wanted to pacify Turkey. A public statement from the Hatay celebrations in 1939 reads, "the independence of Hatay was accepted by the League of Nations in 1937"17 and "on June 291939 the Hatay Parliament terminated itself and on July 71939 the Hatay Province Law was accepted and as a result, instead of a Hatay State, there was the Turkish Hatay province consisting of six districts including Iskenderun, Reyhaniye, Yayla dagi, Kirikhan, Hasa and Dort yolu, with Antakya being the central district"18. Due to French lobbying, the League of Nations gave Turkey the green light on annexing Antakya.

In short, without the colonial hand of France, the fate of Antakya (and the Arab Alawites) could have been different. As it is the case with many colonies/mandates, territories have been used as bargaining chips throughout

${ }^{17}$ Public talk by Cumhuriyet Halk Partisi (CHP) political party official in Corum, 23 July 1939, 490-01-21-106-1, page 127, Celebrations for the Anniversary of Hatay's Liberation, Prime Ministry State Archives- Republican Era, Ankara, Turkey

${ }^{18}$ Public talk by Cumhuriyet Halk Partisi (CHP) political party official in Corum, 23 July 1939, 490-01-21-106-1, page 128, Celebrations for the Anniversary of Hatay's Liberation, Prime Ministry State Archives- Republican Era, Ankara, Turkey 
history. Antakya, too, was used as a bargaining chip between France and the newlyfounded Turkish state. The local minority groups were those who bore the brunt of this territorial transaction.

\section{The Portrayal of Arab Alawites (Nusayris)}

Those who write 'official' history also claim the right to define the populations they come to control. During my archival research, I came across two important documents, both titled "Nusayris", which aimed to describe who Arab Alawites were and what they stood for. Unfortunately undated, these documents are crucial evidence of the attempt to link Arab Alawites to Turkish ethnicity, by calling them "Nusayri" or "Hittite Turks" or "Hata Turks". Several decrees referred to Nusayris as "ethnic Turks who have forgotten their mother tongue Turkish"19. My informants often complained how they have always been defined by others, whether by the state or the media. The goal of the first Arab Alawite conference in November 2015 by the Arab Institute was to create a platform, accessible to all, on which Arab Alawites could discuss, define and identify themselves.

Throughout colonial history, we have seen how colonizers have assumed the right to investigate and describe the population they come to rule. This has certainly been the case for the Middle East, particularly the Arab Muslim populations. Said (1978) and Mitchell (1988) have done extensive and ground-breaking work in deconstructing Western perspectives and representations of the Muslim Arab

${ }^{19}$ Decree signed by Ataturk, the Department of Decrees, 7 April 1938, 030-18-0102-84-68-11, Prime Ministry State Archives- Republican Era, Ankara, Turkey 
societies, which were often based on binary oppositions. Similarly, the Turkish state produced its own representations of the 'Nusayris' and did everything in its power to disconnect Nusayris from Arabs (and Europeans) and to attach them to Turkish ethnicity (Mertcan, 2014). Mertcan writes that the Turks went as far as presenting 'scientific' research that claimed that "Antiochian Alevis" were "definitely not Arab, but Turkish" based on their physical traits and skull dimensions (2014: 191). The first archival document supports this claim by stating how, "The Nusayris are a people who are part of the Turkish race and this is an unwavering truth" 20 . The report further argues that European authors erroneously identified Nusayris as "Petites Chriestiens", in other words, "little Christians". The second document refutes the claim that due to the "many light brown-haired and blue-eyed people" European authors have wrongfully claimed that Nusayris are of French heritage ${ }^{21}$.

In Feminist and Postcolonial Engagements, Sharp (2003) highlights the importance of "naming" and how it is part of identity formation and rituals of incorporation. Self-identification is an assertion of power and ownership and by identifying Nusayris, the Turkish state is not only trying to take away that power from them, but is also trying to strip them off their culture and history. These tactics are part of the Turkish nation-building project, aimed to erase Arab Alawite identity and script them as part of the new Turkish nation.

\footnotetext{
${ }^{20}$ Written report on Nusayris, undated, 490-1-584-17-2, page 1, General Report about Nusayris, Prime Ministry State Archives- Republican Era, Ankara, Turkey

${ }^{21}$ Written report on Nusayris, undated, 490-1-584-17-2, page 41-42, General Report about Nusayris, Prime Ministry State Archives- Republican Era, Ankara, Turkey
} 
Aside from the various explanations of the ethnic and religious heritage, the documents reveal the secret belief system of 'Nusayris'. Arab Alawites are a religious community based on concealment and have struggled throughout history to remain as such. In fact, this secrecy is interpreted as an act of resistance to the state (Can, 2011). The unveiling of their secret religious system by Turkish authorities is in itself an act of stretching out dominance over Arab Alawites and trying to dismantle their resistance.

\section{Positioning the Arab Alawites in the Turkish Nationalist Imaginary}

Arab Alawites have endured systematic massacres throughout history. Even though they have not experienced such direct massacres recently, unlike the Anatolian Alevis (such as the 1993 Sivas and 1978 Maras massacres), they have endured their share of hardships. Aside from the more tangible assimilation efforts, such as bans on speaking Arabic, there has been severe psychological oppression, for which language politics has become a tool. For example, a psychological assimilation tactic is the construction of Arabs and the Arabic language as "backward" (Mertcan, 2014). Feminist activist and politician Leyla says:

"They put pressure on language here. As you know, the best way to assimilate a society is through religion and language. It may not be your research area, but Adana and Mersin also endured these assimilation projects, but it was more intense here due to the greater Alawite population."

The psychological violence carried out by the state did infiltrate the Alawite community, and its effects can be observed today. During the opening talk of the 
Research Institute, Dr. Matkap poignantly recalled a story about his teenage daughter. This tale symbolizes the wound of the Arab Alawite community, their dilemma with their ethnic identity, and their "double consciousness" (Du Bois, 2006 [1903]). Dr. Matkap recited:

"My daughter was in second or third grade. One day, when I told her that our roots were Arab, she looked at me with an expression that exuded shame, but more so disgust, and told me that this could not be possible. She told me that she was an authentic Turk and a happy one indeed. Dear friends, thankfully my daughter does not think that way anymore. However, we have a big and important problem in front of us. While no one, not one individual or teacher had told my daughter that being Arab was something to be ashamed of, how was it that my daughter had felt shame and disgust? The answer to this problem is precisely our main study area."

In the Turkish nationalist imaginary, Arabs are labelled as "traitors" and "backward" people, which manifest through the 'informal' in ways such as jokes, mundane conversations, and even proverbs. Dr. Matkap calls this 'Turkish Orientalism', which is built on a negative perspective of Arabs. On World Arabic Day (December 18 ${ }^{\text {th }}$ ), HDP parliamentarian from Batman and president of Anadolu Arap Birligi (Anatolian Arab Union) Mehmet Arslan, brought up some of the daily, racist sayings people use in Turkey. For example, in Turkish, when one does not understand a complex matter, they say "I'll be Arab if I understand!", or when something gets very messy or complicated, they say, "it's turned into an Arab's hair".

Within Turkish ethnocentrism, Arabs are constructed as dark-skinned, lowclass, and back-stabbing people. This narrative of 'backstabbing Arabs' is mainly due to the Arab Revolt in 1916 (Mertcan, 2014: 120). Up until then, Arabs and Turks 
were in some form of cooperation, but some Arabs were getting tired of Turkish nationalism forced down their throats, hence began building separate alliances, or seeking independence (Mertcan, 2014: 120). What many Turks forget or ignore, however, is the fact that there were many Arabs (and other minority groups such as Kurds) who fought in the Ottoman military during World War I. As a matter of fact, many Arabs also fought during the War of Independence, alongside Ataturk, the founder and first president of the Turkish Republic, but have never been recognized as "war heroes" (Mertcan, 2014: 122). Arab Alawites in particular helped the Kemalist movement against French forces in Adana, Mersin, and Alexandretta (Iskenderun) (Mertcan, 2014: 129).

In current day Turkey, Arabs are continuously being labeled as 'dirty' and 'backward', Bilge says. This can be observed in language, for example. While there is a myriad of reasons why the newer generation of Arab Alawites barely speak Arabic (which I will get into more detail in Chapter 4), one of the reasons is the construction of the modern-backward/ Turkish-Arab binary. Thus, speaking Turkish without an accent is perceived as being modern and progressive, while speaking Arabic (or speaking Turkish with an Arabic accent) is considered backward and looked down upon.

All the processes I have laid out in this section (the French involvement in the annexation, the portrayal of Nusayris, and Orientalist views) indicate that Antakya should be perceived as a postcolonial territory. This understanding goes strongly against the Turkish nationalist view that deems Antakya as essentially 
"Turkish" land that was once lost and finally reunited with the motherland. To produce and support this script, however, the state and its extensions had to undertake a series of actions to erase any other identity. Arab Alawites were one of the identities that needed to be assimilated, which I will get into in the next section.

\subsection{Turkey's Assimilation Politics}

Examining the politics of naming, language, and intermarriage, in this section I show how the Turkish state used incentives as well as coercion to assimilate Arab Alawites in Antakya. The state relied on a multiplicity of individuals and institutions to carry out this task, from historians to religious leaders, from teachers to geographers, from village elders to local businesses, each playing their part in building a nation under one identity.

\section{Power and Politics through Naming: "Hatay" - "Hata" - "Hittite"}

During the nation-wide celebrations on the day of the annexation, several public talks explained why the new territory was renamed "Hatay". Historically, this region was characterized by the settlements of Iskenderun (Alexandretta) and Antakya (Antioch). The new Hatay province encompasses both cities, in addition to several other towns, described as 'districts'.

One specific speech delivered in the city of Corum states that 'Nusayris' were "Hata" Turks from China's "Hatay" province, who migrated to this region centuries ago and settled down in Iskenderun and Antakya and named this territory "Hatay", 
as a reference to their motherland ${ }^{22}$. The speaker continues to explain how, "the Turks who are living in Antakya, Iskenderun and their surroundings today, are the authentic children of the Hata Turks, who have made this region their motherland at least four thousand years ago"23. The erasure of other ethnic groups living here continues further with the statement, "this region is a pure Turkish homeland, from the materiality of its soil to the spirituality of its people"24. Yet another speech offers a historical and geographical explanation on why this region is called "Hatay":

"Hatay, the area encompassing Iskenderun and Antakya in southern Anatolia, has been Turkish land ever since history was recorded... Today, we call this area Hatay in order to reinvigorate an older phrase. When we say Hatay, we mean the area of Iskenderun and Antakya"25.

According to further speech, Antakya and Iskenderun were settled by "Hittite Turks 2000-2500 years ago" and had been ruled by "Hittite Khans" for centuries. ${ }^{26}$

${ }^{22}$ Public talk by Cumhuriyet Halk Partisi (CHP) political party official in Corum, 23 July 1939, 490-01-21-106-1, page 125, Celebrations for the Anniversary of Hatay's Liberation, Prime Ministry State Archives- Republican Era, Ankara, Turkey

${ }^{23}$ Ibid.

${ }^{24}$ Ibid.

${ }^{25}$ Public talk by Dr. Cemal Alper, 23 July 1939, 490-01-21-106-1, page 180, Celebrations for the Anniversary of Hatay's Liberation, Prime Ministry State Archives- Republican Era, Ankara, Turkey

${ }^{26}$ Public talk by Cumhuriyet Halk Partisi (CHP) political party official in Izmir, 23 July 1969, 490-01-21-106-1, page 67, Celebrations for the Anniversary of Hatay's Liberation, Prime Ministry State Archives- Republican Era, Ankara, Turkey 
Attempts to prove the Turkish-ness of Hatay also include geographical explanations, aimed to disassociate the region with Syria. One statement reads, "This region, from the land to its climate and agriculture is entirely Anatolian. It has absolutely nothing to do with Syria, neither its people, nor its soil, climate, agriculture or economy"27. It further reads:

"The nationality and culture of the Hatay population is connected to Anatolia. Without an accent, the people speak like Anatolia, meaning they speak Turkish... the Turkish language has lived on in this region, but in the arid and barren regions of Syria the mother tongue Turkish was forgotten. In this sense, too, Hatay is a Turkish province." 28

Syrian newspapers were blamed for propagating to make Hatay "Arab" and connect it to the rest of the Arab world ${ }^{29}$. But in the eyes of Turkish nationalists, Hatay had nothing to do with Syria and everything to do with Anatolia ${ }^{30}$ and henceforth, there

${ }^{27}$ Public talk by Dr. Cemal Alper, 23 July 1939, 490-01-21-106-1, page 180, Celebrations for the Anniversary of Hatay's Liberation, Prime Ministry State Archives- Republican Era, Ankara, Turkey

${ }^{28}$ Public talk by Dr. Cemal Alper, 23 July 1939, 490-01-21-106-1, page 181, Celebrations for the Anniversary of Hatay's Liberation, Prime Ministry State Archives- Republican Era, Ankara, Turkey

${ }^{29}$ Public talk by Dr. Cemal Alper, 23 July 1939, 490-01-21-106-1, page 186, Celebrations for the Anniversary of Hatay's Liberation, Prime Ministry State Archives- Republican Era, Ankara, Turkey

${ }^{30}$ Public talk by Basri Tozun, 23 July 1939, 490-01-21-106-1, page 42, Celebrations for the Anniversary of Hatay's Liberation, Prime Ministry State Archives- Republican Era, Ankara, Turkey 
would be only "one language and one race"31. As one speaker argues, "even our enemies did not deem it necessary to prove that Antakya and its surroundings are pure Turkish homeland"32.

The existence of other ethnic and religious groups in the region is almost completely erased in the archives. There are a few mentions of Greeks and Armenians ${ }^{33}$ and Syrians, Alevis, Arab Orthodox and Armenians ${ }^{34}$. These mentions are inserted either to minimize their existence by calling them a "small minority" or to warn the state of "suspicious activities" of these groups along the border of Syria.

\section{Facilitation of Intermarriage and Language Courses}

I came across four different documents, titled "Decree", all of them communicating the same message. Even though they are referring to the "Nusayris" in the southern city of Mersin, which is one of the major Arab Alawite settlements aside from Antakya and Adana, I found the decrees important to note. Figure 2.2 is

\footnotetext{
${ }^{31}$ Public talk by Basri Tozun, 23 July 1939, 490-01-21-106-1, page 43, Celebrations for the Anniversary of Hatay's Liberation, Prime Ministry State Archives- Republican Era, Ankara, Turkey

32 Public talk by Fethi Arik, 23 July 1939, 490-01-21-106-1, page 83, Celebrations for the Anniversary of Hatay's Liberation, Prime Ministry State Archives- Republican Era, Ankara, Turkey

${ }_{33}$ Public talk by Dr. Cemal Alper, 23 July 1939, 490-01-21-106-1, page 182, Celebrations for the Anniversary of Hatay's Liberation, Prime Ministry State Archives- Republican Era, Ankara, Turkey

34 Telegraph sent from Payas, Iskenderun by the local branch of the Ministry of Foreign Affairs, 10 July 1938, 030-10-224-511-2, page 1, Prime Ministry State Archives- Republican Era, Ankara, Turkey
} 
one of the four decrees that announce funding for "cultural centers" in order to teach the Turkish language to Nusayris, who are "part of Turkish culture and have forgotten their mother tongue" 35 . One of the decrees refers to Arab Alawites as "Hittite Turks"36. The funding is also allocated for the easement of dowry expenses. As Mertcan (2014) also indicates in his book, the state gave money to 'mixed' weddings, to encourage intermarriage between Arab Alawites and Turks.

Such funding distributions are part of the assimilations politics of the Turkish state. Nevertheless, I found yet another set of documents, dating post-annexation (1947), which claim, "around one thousand Alevis, who have chosen to be part of Syria during Hatay's annexation to the motherland... have been searching for solutions to return to Hatay. We believe these Alevis have no political goals and want to become Turkish quickly, lovingly and willingly..."37. Allowing "willing" Arab Alawites into the country and facilitating their transformation into Turkish citizens is an example of the state's encouragement of Arab Alawite assimilation. Mertcan (2014) also presents examples from the state archives where national newspapers glorify 'Nusayris' who are eager to become Turkish.

\footnotetext{
${ }^{35}$ Decree signed by Ataturk, the Department of Decrees, 7 April 1938, 030-18-0102-84-68-11, Prime Ministry State Archives- Republican Era, Ankara, Turkey

${ }^{36}$ Decree signed by Ismet Inonu, the Department of Decrees, 5 August 1939, 030-1801-02-88-77-16, Prime Ministry State Archives- Republican Era, Ankara, Turkey

${ }^{37}$ Letter from the head of the CHP Hatay Office Dr. Vedi Bilgin to the CHP General Directorate in Ankara, 18 January 1947, 490-1-584-17-1, page 3, Prime Ministry State Archives- Republican Era, Ankara, Turkey
} 


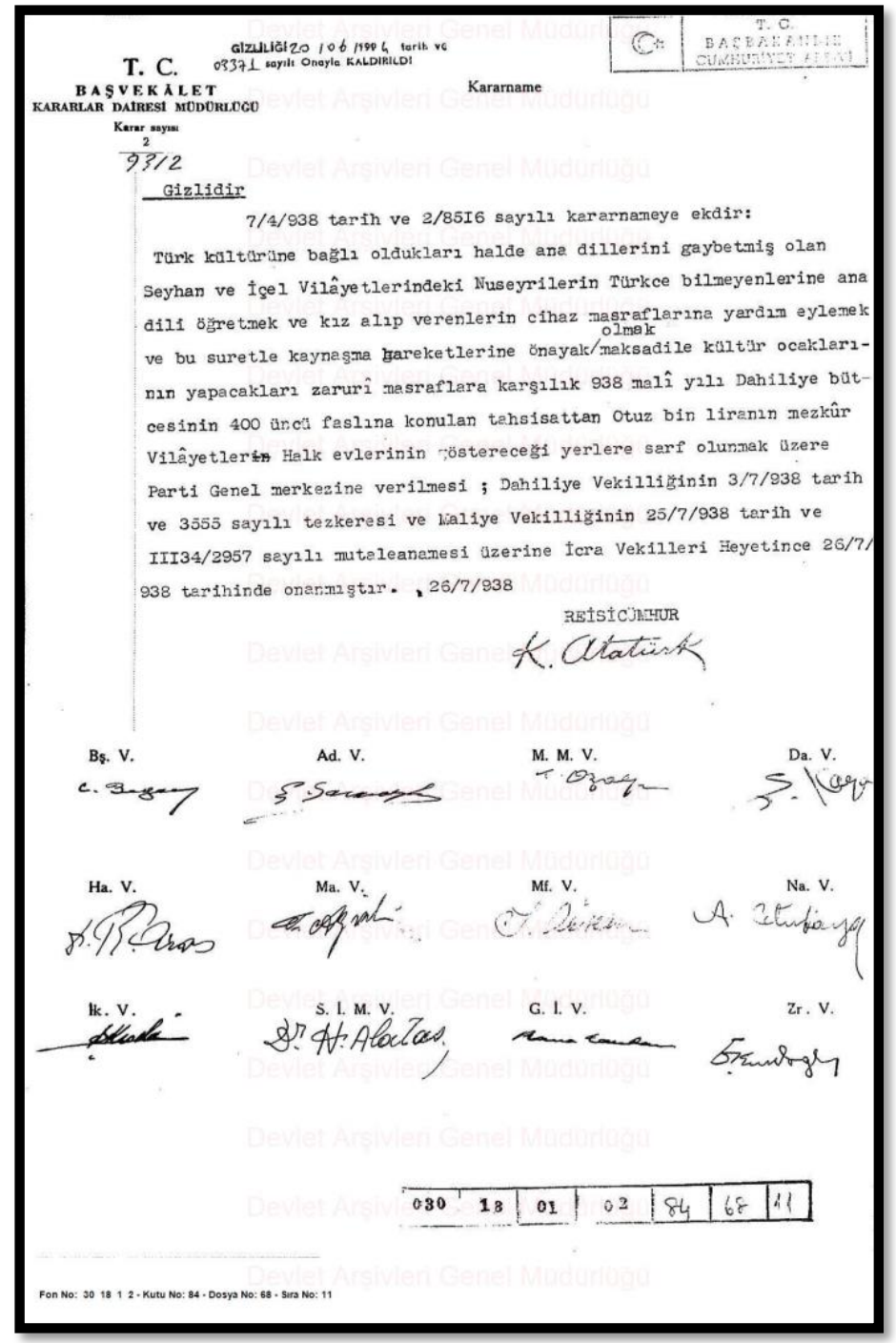

Figure 2.2. One of the four decrees that authorize state funding for cultural centers signed by Ataturk (030-18-01-02-84-68-11)

Such assimilation tactics were successful to a certain extent, causing some separation among the Alawite community (Duman, 2016). Duman writes that the state used coercion with the lower-class Alawites, while using enticement with the more affluent Alawites (2016: 232-233). Thus, we can see from the archived newspapers how certain sheikhs and influential Alawites became part of the 
assimilation efforts by cooperating and aiding the Turkish state (Mertcan, 2014: 177-180).

\subsection{Gendered Language: Antakya as a Child/Girl Needing to be Saved}

Although archival curation, nationalism, and colonialism are masculinist endeavors and are patriarchal at core, in this section I take the time to spell out the various gendered implications of the Turkish nation-building project during the annexation period. I pay attention to the gendered representations of power and I critique macro-analyses of the state. As Cynthia Enloe remarks, nationalisms have “typically sprung from masculinized memory, masculinized humiliation, and masculinized hope" (1989: 44). Hence, it is critical to locate and break down these masculinized representations in order to deconstruct the Turkish nationalist script.

\section{Symbolism of Child/Girl}

The archival collection of public talks and poems recited at the nationwide celebrations of Hatay's annexation provided a rich site for the analysis of gendered language. The speakers of the manuscripts I read, keenly imagine Hatay as a suffering child who has fallen apart from its mother and needs to be reunited. The excerpt I used in the very beginning of this chapter is a perfect example to this sentiment. That excerpt follows, "after twenty years of longing, we have reunited 
with Hatay. We embraced it tightly and are sniffing it with joy" ${ }^{38}$. The speakers rely on the narrative of infant-mother, because an infant can only have one true mother and can only be comforted by its mother. The "natural" relationship between infant and mother is thus used as appoint-of-reference for the relationship between "Hatay" and the motherland.

In the documents, I found a popular narrative of an interaction in the southern province of Adana, between a little girl from "Hatay" dressed in all black and Ataturk, the founder of the Turkish Republic. According to this story, the little girl approaches Ataturk with flowers in her chained hands and tears in her eyes, begging him to save their homeland. Ataturk is very touched by this little girl and replies with tears in his eyes, "the land that has always been Turkish will not stay captive. Hatay will be freed. Be at ease" 39 .

In this narrative, the little girl in all-black and teary eyes symbolizes "Hatay". In this case, a little girl is a fitting symbol for Hatay, since little girls are those who need saving the most. Her chained hands represent the city's captivity, while the allblack symbolizes the backward state of Hatay under the Syrian Mandate. In some

\footnotetext{
${ }^{38}$ Public talk by Cumhuriyet Halk Partisi (CHP) political party official in Corum, 23 July 1939, 490-01-21-106-1, page 124, Celebrations for the Anniversary of Hatay's Liberation, Prime Ministry State Archives- Republican Era, Ankara, Turkey

${ }^{39}$ Public talk by Cumhuriyet Halk Partisi (CHP) political party official in Corum, 23 July 1939, 490-01-21-106-1, page 126, Celebrations for the Anniversary of Hatay's Liberation, Prime Ministry State Archives- Republican Era, Ankara, Turkey
} 
documents the girl is described as holding flowers, while in others she is holding a Turkish flag.

One document claims that even in his deathbed, remembering the little girl begging to be saved, Ataturk inquires about Hatay. He vows to "save" Hatay and the little girl, who in the meantime must have "reached her bridal age" 40 . The talk ends with the speaker calling out to the girl:

"You, girl from Hatay, take off your black veils and put on the red and white bridal gown that suits you, we are coming to crown you with flowers from the motherland" 41 .

Again, this phrase is laced with symbolic expressions. The unveiling of the girl in black represents Hatay's liberation from Arab backwardness, while her slipping into a red and white gown represents her becoming part of "modern Turkey". Figure 2.3 is a photo I came across in the state archives. It is a photo of a little girl in the catalog of the annexation celebrations, wearing a white dress and a crown on her head, with a banner across her chest that reads "Hatay". She stands high on a pedestal among flaming torches and between two enormous Turkish flags, with a soldier on each side. While there is no information on the context of the photo, I am inclined to

\footnotetext{
${ }^{40}$ Public talk by Celal Bayar, 23 July 1939, 490-01-21-106-1, page 35, Celebrations for the Anniversary of Hatay's Liberation, Prime Ministry State Archives- Republican Era, Ankara, Turkey

${ }^{41}$ Public talk by Celal Bayar, 23 July 1939, 490-01-21-106-1, page 36, Celebrations for the Anniversary of Hatay's Liberation, Prime Ministry State Archives- Republican Era, Ankara, Turkey
} 
assume that it is a reenactment of the tale of the girl from Hatay, at last unveiled, crowned, and part of the Turkish nation, always protected.

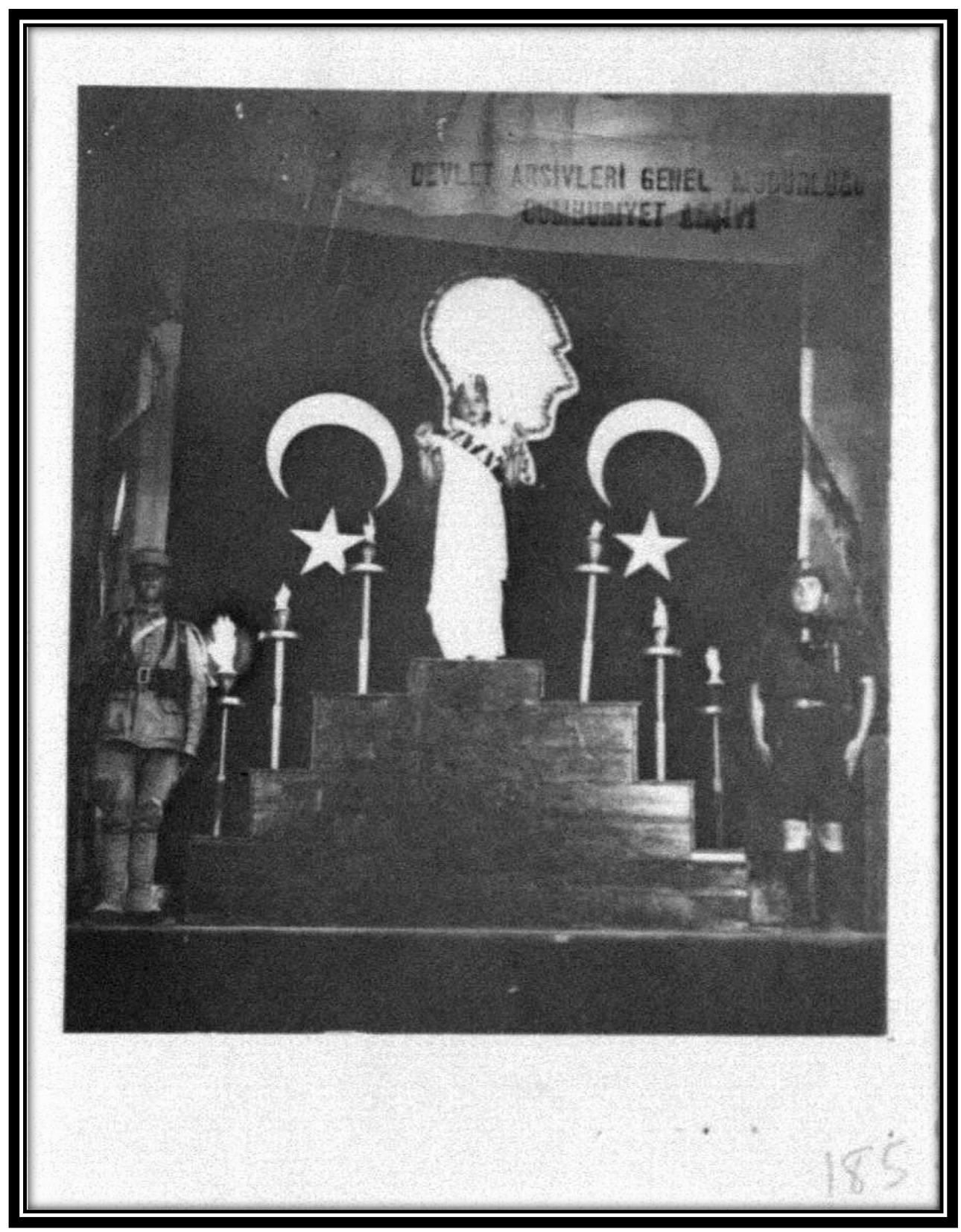

Figure 2.3. Photo of a girl with a "Hatay" banner, standing between two soldiers, with a backdrop of Ataturk and the Turkish flag, 490-01-21-106-1-185 
In the nation-building project, "women are typically constructed as the symbolic bearers of the nation but are denied any direct relation to national agency" (McClintock, 1997: 90). Their role is merely "metaphoric or symbolic" (McClintock, 1997: 90). We can observe this in the Turkish nation-building process, as the little girl symbolizes bearers of the nation who have no agency. Symbolisms such as flowers, bridal gowns, crowns, and veils do the work on the intricate level. Such is the power and inner-workings of nationalism, expressing itself through gendered language and visuals.

\section{Gendered Narrative of Hatay in Captivity}

Once the Turkish army was forced to evacuate Antakya in 1919, "Hatay" became the "land conquered by the French". Under this narrative, Antakya was portrayed as eroding under the occupation. One documents claims, "Antakya has eroded under the French occupation, many arts and crafts have vanished and the city has lost its significance as a marketplace" ${ }^{42}$. Another document supports this claim, "After separating from Anatolia, the business and cultural life of this region has suffered tremendously"43. These claims are used to further legitimize Turkey as

\footnotetext{
${ }^{42}$ Public talk by Dr. Cemal Alper, 23 July 1939, 490-01-21-106-1, page 182, Celebrations for the Anniversary of Hatay's Liberation, Prime Ministry State Archives- Republican Era, Ankara, Turkey

${ }^{43}$ Public talk by Basri Tozun, 23 July 1939, 490-01-21-106-1, page 43, Celebrations for the Anniversary of Hatay's Liberation, Prime Ministry State Archives- Republican Era, Ankara, Turkey
} 
the rightful owner of this region and to demonstrate how "Hatay" has "suffered" at the hands of its illegitimate rulers.

Similar to the narrative of Hatay being "conquered by the French and Syrians", there is also the narrative of Hatay as an infant that needs to be saved from captivity. Several literary pieces were written on this narrative and recited at the national celebrations of Hatay's annexation. For example, a marching song titled "Hatay's Liberation March" reads:

"Captivity does not suit brave/manly Turk at any time; Turks have never been a servant or slave to anyone; especially you, Hatay, the magnificent land; could not have remained in captivity for years... we are sons of Turks, sons of Turks... good news my citizens, Hatay was liberated."44

In this verse, the Turkish nation is described as having masculine attributes, such as "brave", "manly", always "powerful", while Hatay is feminine, powerless and needs saving. Nation-building relies upon such masculine/feminine representations, not only to resonate with traditional gender roles and thus appeal to the common citizen, but also to reinforce the patriarchal structure of the nation-state.

Another example is an excerpt from a poem read at the annexation celebration:

${ }^{44}$ Public talk by Lutfi Oguzcan in Eskisehir, 23 July 1939, 490-01-21-106-1, page 6, Celebrations for the Anniversary of Hatay's Liberation, Prime Ministry State Archives- Republican Era, Ankara, Turkey 
"Hatay, run to me; this hand is your mother's; I am fed up with longing for you, come; do not leave my embrace again." 45

Here, Turkey represents the mother, the feminine, who is longing for her child. Within feminist political theory, the nation is often feminine, as the term "motherland" suggests. Women are "bearers of the nation", hence are important for the future of the country. Along this logic, Hatay carries importance for the country's future and it becomes necessary to reunite this land with the mother.

The "Hatay Issue" (Hatay Meselesi) is an important part of modern Turkish history. Kids at school are taught the narrative of Hatay that has always been Turkish and had to be reunited with the motherland. For the most part, the production of borders and territoriality are not questioned and this narrative goes unchallenged. Furthermore, the impact of the border on the attitudes of the people living within the border region is not taken into account. Thus, the case of Hatay is an ideal example of how territories are not fixed, are continuously contested, and determine belonging/exclusion.

In this chapter, drawing on oral history and archival records, I engaged with varying accounts and perceptions of the events surrounding Antakya's annexation. I listened to the voices 'on the ground' that challenge the dominant narrative and gave concrete examples of what this challenge looks like. Critical of the colonial

\footnotetext{
${ }^{45}$ Public talk by Ali Tan, 23 July 1939, 490-01-21-106-1, page 78, Celebrations for the Anniversary of Hatay's Liberation, Prime Ministry State Archives- Republican Era, Ankara, Turkey
} 
powers in play, I explained how the 'handling' of the "Hatay Issue" by France and Turkey carry colonial dispositions. Also, alluding to the Turkish state's attempted erasures and (re)definitions of the Arab Alawite people, in addition to the Orientalist views on the Arab peoples, I argued that Antakya should be regarded a postcolonial region. Forced and induced assimilation strategies through naming, language, and intermarriage, add another layer of colonial practice.

Secor (2001) argues that feminist geopolitics does not replace the 'global' with the 'local', but shows how violence, resistance, politics, and change happen on multiple scales. This chapter shows how certain colonial practices and nationalist policies have trickled down to the everyday lived experiences of the Arab Alawites in Antakya, hence showing how the international, national, and local influence each other (Pratt and Rosner, 2006; Mountz and Hyndman, 2006). In line with the feminist geographic understanding of the nation as always gendered and socially produced, I showed how the Turkish state constructed women as bearers of the nation and used their bodies as sites of nationalism. This gendering of Turkish nationalism within the colonial production of the Antakya region offers new insights within the study of post-Ottoman Turkey and expressions of Turkish nationalism. It also builds on and expands existing scholarship on nation/nationalism and gender (Yuval-Davis, 1996; Mayer in Staeheli, Kofman and Peake, 2004; Secor, 2007; Fluri, 2009; Faria, 2013).

Zeroing into women's experiences, in the coming chapter I focus on religion and gender, resistance to patriarchal religious practices, and women's role in 
cultural preservation. Since religious identity plays an important role in this region, I am interested in understanding Arab Alawite women's religious experience and how it influences their political subjectivity and social visibility. 


\section{CHAPTER 3: Feminisms in the Muslim World: Arab Alawite Women's Religious Experience}

"[C]alling attention to the resonances of contemporary discourses on equality, freedom, and rights with earlier colonial and missionary rhetoric on Muslim women, I argue that we need to develop, instead, a serious appreciation of differences among women in the world - as products of different histories, expressions of different circumstances, and manifestations of differently structured desires."- (Abu-Lughod, 2002: 783)

Building onto my analysis in the previous chapter on gender and nation, in this chapter I add another layer of analysis through a discussion on gender and religion, within a framework of Islam. Building onto Mohanty's critique of the "unitary notion of religion (Islam)" within previous scholarship on women in Islam, I aim to contribute to scholarly work that deconstructs "a specific version of Islam as the Islam" and the attribution of "a singularity and coherence to it" (2003: 29). Recognizing heterogeneity within the Islamic experience is particularly important for the study of women's politicization in the Middle East, as religious subjectivity heavily informs political tendencies and women's agency.

In this chapter, I use primary and secondary sources to understand the complex relationship between women and the Arab Alawite faith. Particularly, I am interested in how women's exclusion from certain religious practices affects their religious experience. What are some of the critiques women have of Arab Alawism? How do women negotiate the seeming contradiction between religious exclusion on one hand and increased freedom on the other? How do they construct their religious 
identity under such exclusionary practices? Does religious or sectarian affiliation play a role while choosing their spouse? I draw on literature on Arab Alawism and data from my in-depth interviews, focus groups, and participant observation and offer a gendered analysis of faith, women's position within it, and the embodied contestations and negotiations.

The significance of this chapter lies in its contribution to the study of women and gender in the Middle East (Mahmood, 2001; Secor, 2011; Abu-Lughod, 2002; Fluri, 2008; Badran, 2009; Gokariksel and Secor, 2010). Feminist scholars such as Abu-Lughod (2002) and Badran (2009) warn against a homogenous understanding of the Muslim woman's experience. Badran dismantles this perception through her work on feminism(s) in Islam, while Abu-Lughod warns against the polarization of feminisms in the Muslim world and the West:

"One of the things we have to be most careful about in thinking about Third World feminisms, and feminism in different parts of the Muslim world, is how not to fall into polarizations that place feminism on the side of the West" (2002: 788).

This chapter builds on this understanding of Muslim women and their heterogeneous social and political experience, as opposed to one that paints Muslim women as universal victims of hegemonic culture. My findings show a unique understanding and practice of Islam among the Arab Alawite women of Antakya, which vary depending on class, political view, family structure, and rural/urban environment. 
This part of my research (where women stand in the Arab Alawite religious order) was particularly exciting for Alawite women, mainly because no one had been interested in talking to women about Arab Alawism. Since Alawism is based on male concealment (details follow below), researchers have been primarily interested in talking to sheikhs or male community members. Therefore, from a religious perspective, this study can be considered a first. My interviewees were especially keen on reading the final product and have it as a source material. As part of my endeavor in activist research (Kobayashi, 2001; Pratt, 2004), I will share this dissertation and any articles that are born out of it with the host community.

I begin by giving a brief overview of the Arab Alawite belief system and the religious concealment by relying on the explanations of 'insider' sources. I then explain how women are not given 'the secret', how they respond to this exclusion, and how they reinterpret it to their advantage. Here, I draw on feminist political theory on gender and religion, everyday resistance, and patriarchy within religion. In the following section, I refer to interdisciplinary studies on cultural preservation/ hegemony and the connection between morality and religion to discuss intermarriage and the tension between Alawism and Sunnism. The last section in this chapter touches upon a growing threat to Muslim minority groups in Turkey, which is the Sunnification of political and social spheres. Through the example of a popular Alawite sheikh, I highlight some of the concerns of the Alawite community. 


\subsection{Brief Overview of Arab Alawism as a Belief System}

Arab Alawites are a heterodox Islamic group (Mertcan, 2014: 5). Considered a sect within Islam ${ }^{46}$, Arab Alawism is a belief system that is passed on orally and based on secrecy, making it rather difficult to research its inner-workings from secondary sources. There are very few written sources on Arab Alawism, the most renowned being Muhammad Ghalib at-Tawil's book The History of Arab Alawites, originally published in 1924. As a member of the Arab Alawite community, the former Ottoman official at-Tawil of Adana offers the initial, as well as the most comprehensive history, of the Alawite community. The few who followed suit have been mostly outsiders, a trend the Alawite community discontents, and offered mainly cultural analyses. The more recent additions to the literature are by members of the Alawite community (see Sertel, 2005; Can, 2011; Mertcan, 2014). These authors observe the 'for us by us' model and present a considerably more authentic, and politicized, narrative by counteracting the myriad of fabricated, skewed, and often derogatory information on the Arab Alawite community.

As this research project is primarily concerned with women's identity and role within Antakya's Arab Alawite community, I opted out of investigating and presenting an exhaustive summary of the intricacies of the Arab Alawite belief system, since it is beyond the scope of my project. I will however, for the sake of contextualizing Alawite women's religious experience, provide a brief explanation of

46 Although Arab Alawites overwhelmingly identify as Muslims, they have been discredited by Sunni Muslims throughout history, often labeled as 'heathens' or 'deviants of Islam'. 
the general workings of the Alawite religious belief system, with basic comparisons to the more known Islamic sects in the region.

Arab Alawites believe in one God, consider the Quran their holy script, and accept Mohammed as their prophet. They also highly respect the fourth caliph Ali. Similar to Anatolian Alevis and Shia Muslims, they believe Ali should have been the first caliph after Prophet Mohammad's death. The injustices Ali has endured in his lifetime have not only left a profound mark, but continue to shape the collective memory and consciousness of the Alawite community, which I will further elaborate on in Chapter 4.

The concept of Ehli Beyt ${ }^{47}$ plays a central role in the Arab Alawite belief system, as they claim to be direct descendants of the Ehli Beyt (Can, 2011). This concept coincides with Arab Alawism being a closed belief system. Subsequently, one cannot become an Alawite, but must be born into an Alawite family. For hundreds of years the belief system with its religious codes, rituals and traditions has been passed on orally to the male members of the community. Once a boy reaches an age where he is capable of learning, understanding and processing the religious secret (usually around 14-15 years of age), the family picks an Amca (uncle) from the community, who becomes the official mentor of the boy for the coming months. During the religious training, the boy lives with and becomes part of

47 Ehli Beyt refers to the immediate family of the Prophet Mohammed, which includes his cousin and son-in-law Ali, daughter Fatma, and grandsons Hasan and Huseyin. 
the mentor's family (Can, 2011). Over consecutive months, the boy receives the religious secret and learns how to perform namaz, a form of worship.

Arab Alawites do believe in the Quran, however their interpretation differs from the more mainstream Sunni interpretation. Alawites believe in the concept of zahir and batin, which claims there are apparent and hidden meanings of the Quran, the hidden interpretation being the superior (Sertel, 2005: 75). Similar to the Anatolian Alevis, Arab Alawites do not worship at the mosque like Sunnis do. There are differing explanations on this rule. The most common reasons are the oppression they endured for many years, forcing them to worship in secret, and their distinctive performance of namaz (Sertel, 2005:79). Certain Anatolian Alevi factions, for instance, perform cem, which typically takes place at a cemevi, their worship site. Both men and women perform cem together, which consists of a series of symbolic acts. For Arab Alawites, however, namaz involves men only. There are two types of namaz. The first one is the collective namaz, usually performed at a religious ceremony or offering at a house or ziyaret ${ }^{48}$, consisting of prayers and some bodily gestures. The second type of namaz is performed individually and can be done anywhere, at any time, without visible gestures. Yet another major distinction that sets Arab Alawites apart is their belief in reincarnation, or transmigration, which includes incidents such as rebirth, resurrection or soul migration (Sertel 2005: 99).

${ }^{48}$ Ziyaret is a site that is considered holy for a number of reasons and are frequented by men and women. 
Alawite women's religious experience significantly differs than of men. In the coming section, I explain women's role and place in the belief system and the reasons behind them. I also highlight some of the critiques I have encountered, which speak strongly against patriarchy within religion.

\subsection{Women in the Arab Alawite Religious Order: Critiques from within}

As mentioned earlier, Alawite women do not receive religious training, do not learn how to perform namaz, do not take part in the collective namaz sessions, and do not become religious leaders. Women receive the zahir (apparent) teachings, but not the batin (hidden) (Sertel, 2005: 77). There are several reasons behind this rule, but considering the absence of textual guideline for the Arab Alawite belief system, these reasons are derived from the consensus of the community, and may vary depending on whom you ask.

The most common cited explanation for keeping the secret from women is their protection (Sertel, 2005: 109). Since Alawites have been oppressed and massacred throughout history (Mertcan, 2014), they had no option but to worship in secret and abstain from putting their belief into writing to cover up their traces. As women's bodies are often considered sites of conquest during times of war (McClintock, 1995), it is said that Alawite men wanted to protect women by keeping them in the dark. This would spare women from being tortured for information. Some also claim that women would be more likely to crack under pressure and expose the secret, which plays on gendered notions of weakness. Another reason 
lies on the premise that when Alawite women marry outside the community, they would be more likely to reveal the secret to their non-Alawite husbands (Sertel, 2005: 109). Yet a third reason, which is not discussed as openly, is more misogynistic in nature. It is said that women "have a big mouth" and cannot be trusted with the secret.

Rima, a university student, expresses her frustration with women's religious exclusion, which discriminates based on biological difference:

“Why don't they trust women? Our mouths supposedly don't stay shut, I hear these things a lot. That women are dirty, because we get our periods, women's and men's clothing cannot be washed together".

During my fieldwork, I did not exactly encounter this perception of women being "impure", "dirty", or "lesser" within the Alawite community. Several male and female members of the community did point out how sexual difference, i.e. the menstrual cycle, was a discriminatory factor, but one that merely highlighted the biological difference between men and women, not necessarily subjugating the latter. I was, however, in one instance, told that the soul cannot reach its destination without being incarnated through the physical body of a male Arab Alawite. This meant that the soul of a female Alawite had to be reborn as a male. I encountered this reasoning only once, during a casual conversation with a man who had undergone training to become a sheikh, but ended up not following through.

The connection between women's bodies and impurity has been investigated within a religious context. Mohyuddin, Sheikh \& Chaudry's (2015) research in the 
Chitral district of Pakistan aims to understand what is considered pure and impure in the Kalash religion. The religion considers males and females as equal, however women and the menstruation home are considered impure. While menstruating, women are not allowed to touch and share anything with men and are required to spend a week in the menstruation home (Mohyuddin, Sheikh \& Chaudry, 2015). Kaundal \& Thakur (2014) argue that in fact all major religions, without exception, have restrictions on menstruating women, regarding worship, cooking, physical intimacy and even separate living. They include Judaism, Christianity, Islam, Buddhism and Hinduism in their analysis. In the Sunni practice of Islam, for instance, menstruating women are forbidden from fasting during the holy month of Ramadan, as they are considered impure. They also cannot perform namaz, handle the Quran, or enter a mosque.

It comes with little surprise that Arab Alawism has similar rules for women. Alawite women reserve the right to read the Quran, engage in conversations about religion with sheikhs and ask them questions, recite prayers, and visit ziyarets, as long as they are not menstruating. A menstruating woman is not supposed to enter a ziyaret or take part in any religious rituals. Traditionally speaking, a divorced or remarried woman is also not allowed to take part in religious rituals, which are considered just as sacred as namaz and mainly consist of cleaning the namaz rooms and preparing/distributing meals. However, divorced women's involvement in the rituals seems to be left up to the discretion of the sheikh leading that ceremony. 
For example, I interviewed Celal, a sheikh from Samandag, who is considered "progressive" by the community. He told me, "we don't condone divorce as a religious structure, but we respect people's choices". From a religious standpoint divorce is not allowed, but in modern lifestyle it carries less weight. The rule about not allowing female divorcees to take part in rituals is eroding with modernization. Ceren, a divorcee from Central Antakya, told me that her family is more laidback and no one openly has opposed her participation in religious ceremonies, including the sheikh.

The double standard of this rule does not go unquestioned. Sevil, a teacher and vice-principal in Samandag, protested how divorced or remarried women are banned from religious service, but this rule does not apply to men. A recent divorcee herself, she explained some of the other discriminations women face in religion:

“Menstruation is a natural part of a women's life, it's a biological process. So you cannot take place in religious service [when you are menstruating]. And there is no connection between you and God, so your husband or father or brother prays for you and you only serve during bayrams ${ }^{49}$. Personally, it's not a problem for me, because I researched and learned what [men] are taught. So I don't feel incomplete. But systematically this is a problem. I think this kind of discrimination should not exist in Alawism, humanity should be important."

Sevil agrees that women are second class in all religions, but she finds it hypocritical that Alawism would discriminate against women, when the whole belief is based upon humanism and takes pride in treating all human equally. This

${ }^{49}$ Religious holiday or ceremony. 
secondary role of women in religion is not an exception when looked at other major monotheistic religious systems. Sertel argues that while the 'women's issue' is a global problem, Islam attracts the most attention and criticism (2005: 107). Gulizar, a university student, believes:

"Arab Alawites are also a patriarchal society, just like any other religion. We don't know much about the secret and this is unfortunately due to the patriarchal structure of our religion. We don't know the namaz and when we try to question it, we find the dogmatic, illogical side of the religion. But this is how all religions are. If you were to ask Arab Alawite men, they would say that women have a privileged status within the society."

Where Arab Alawism stands compared to other world religions was one of the topics discussed during the "Arab Alawism and Women" workshop at the Arab Alawite Conference. The group moderator Gulsum, who wrote her master's thesis on Arab Alawite women's responsibilities in the household, argues that women's secondary position can be observed in almost all monotheistic religions, and neither Islam in general nor Alawism as a sect was an exception. The group's "results and outcomes" report read:

"When we look at monotheistic religions, we see that they all consider women as secondary within society and religious order. All monotheistic religions naturally see women as secondary beings. In the beginning of our discussions, we came to an agreement that Arab Alawism is also part of such a religious system and that Arab Alawites are a patriarchal and patrilineal society. We all agreed that while discussing the status of women, we should keep in mind that we are not that drastically different from the groups we live side by side." 
Nuray, owner of a successful event planning business, takes it one step further. According to her, "no religion or sect is progressive, because they want to control people". Berrin, a social psychologist, thinks that the regional obsession with Arab Alawism stems from the dominant Sunni ideology. She explains, "all monotheistic religions consider women secondary, but the reason why Arab Alawism is questioned so much is because of the dominant culture [Sunnism], and the dominant culture has taught us that way [that it is alright to question Arab Alawism]".

The secondary role of women in the Alawite religious order may be critiqued by many Alawite women as reflecting traditional gender roles, but it would be erroneous to assume that the ritualistic acts are not meaningful. On the contrary, many of my Arab Alawite women informants find comfort, spiritual fulfillment, and a sense of belonging through performing these acts. Burcak, a lawyer from Central Antakya, told me that religious rituals have become mere tradition and she feels spiritually satisfied and happy while serving at religious ceremonies. Some women said it was not right to reduce the meaning of religious belonging and participation to the ability to perform namaz, since women were involved meaningfully in many other ways. Leyla, a feminist activist and politician, explains:

“As for religious rituals, women don't learn the most important ritual, which is "namaz". But they pray to God and have faith within a humanist framework. We don't have strict rules. Women go to religious AA sites and pray. This is up to the women. But in more important religious bayrams, such as Ghadir HUmm, Sacrifice etc. Women are very active during those bayrams, they put a lot of effort and labor into it. During this time, women go to the religious sites and pray. These are the religious rituals of women." 
Still, many women express their frustration with being excluded. During their religious training, boys takes notes and keep their notebook hidden at home, away from the female members of the household. Rima says she wishes she knew what was written in that notebook. Feride, who has a son, says, "even your own son will hide his notebook from you one day". Little girls are also intimated through statements that claim if they listen to the collective namaz, they will become deaf. As a curious child, Nuray told me that she used to listen to the collective namaz and then would tell her elders, "see, I didn't become deaf," as a way of retaliation. And Sevil thinks it is unfair that women "don't exist in religion, but end up being the ones who serve".

For Alawite women, it is pivotal that their criticism comes from their community. Alawites have had to endure questionings, criticism, and persecution from Sunnis for many, many years. On the 'right' to question the Arab Alawite faith, Berrin said:

“Arab Alawite women don't learn namaz, Sunni women do. There is this differentiation. I find this to be nonsense. Not knowing the namaz doesn't mean that I am not part of that religion. Namaz is prayer, that's all. I come from a sheikh family, so I know a lot. I've been reciting prayers since I was a kid. I mean, all those bayrams and kandils ${ }^{50}$ and other rituals, how many of them know the reasons and history behind them? What percentage of the Sunni population knows this? They don't even know Arabic and memorize things they don't know the meaning of. And we don't question them. Do I ask them why they don't accept women to the mosque [during Friday prayers]? Would that mean that women aren't part of the religion? Those women do the namaz at home and our women pray at home. There is a double standard here. The real issue here is that they find the right to question others."

50 One of the five Islamic holy nights, when the minarets are illuminated. 
According to Berrin, the dominant Sunni culture, which upholds the Sunni interpretation as the 'correct' and 'only' way to practice Islam, claims the right to criticize and delegitimize any other interpretation of Islam. Berrin recognizes this double standard and the normalized process of questioning. In her daily life, she began confronting people who question her faith:

“In terms of being Alawite, we don't have special worship rituals, you can do it anywhere and anytime. Therefore, they regard us faithless. So I had to explain this to people, that it's not like that. Also, when I first started working here, a Sunni colleague was drilling me all the time. After a while I realized, I don't have to explain anything about my belief to anyone. And I realized in his Sunni life or personal life, they also have lots of contradictions, in terms of theoretical and practical aspects. But we don't question them, but they question us. I think this is disrespectful. So I became firm about this and I said I don't owe anyone an explanation. This was before the Syria conflict even. I don't know if it's because we are minority, but the dominant group thinks we need to explain or prove ourselves. And what's worse is that we feel like we need to explain ourselves, so that they understand us and see that we are not bad people. We don't want them to judge us, so we want them to understand us and explain ourselves. But they continue to question us and judge us. When I noticed this, I put a stop to it."

According to Iris Marion Young, "Culturally imperialist groups project their own values, experiences, and perspectives as normative and universal" (1990: 123). Victims of cultural imperialism, on the other hand, are considered "deviant in relation to the norm" and marked as Other (1990: 123). She argues that dominant groups do not notice their own group, as their position is supposed to be neutral and universal, but victims of cultural imperialism do not forget their group identity, as the reactions of others call them back to this identity. Arab Alawites do not have 
the option to forget their group identity, because they are questioned and criticized and defined by others on a daily basis, unless they live and work in predominantly Alawite areas. Considering its Islamic practice as the norm, the dominant Sunni group in Turkey tries to delegitimize Alawites as "deviant", based on a myriad of reasons they bring forward, both in terms of theory to practice.

\subsection{The 'Accidental' Benefit of Women's Religious Exclusion}

“As you probably know, in Arab Alawism, women haven't been included into religion that much. I don't really know the real reason for this, neither do my folks. That's why I have this enmity towards the culture I live in ever since I was little, because I always felt excluded. Why do I not know? Why are they worshipping in secret? Why do only men learn? I have always wondered about this and was angry. But as I got older, I began considering this as an advantage, because I was able to choose my own path. Perhaps if I was forced to be a part of something, I would have been stuck with that, but right now I am not." -- Yesim

Women like Yesim rewrite the narrative of the 'excluded' Alawite woman.

Most of my interviewees shared the belief that ideally speaking, women should be given the option to learn namaz and go through the religious training. However, majority of them said if given the option, they would opt out. For instance, Nurdan, who runs an animal feed business, told me:

"I'm not a very religious person as a woman. I don't care about religion that much... I would respect a woman's desire to learn namaz, but I personally wouldn't want to."

Many women feel that if they had increased religious responsibilities, they would experience increased religious pressure. This unique positioning of women 
within religious order was commemorated by two elderly sisters I interviewed, who were convinced the status of women in Alawism does not exist in another religion. Their reasoning was based on their observation that religiosity often translates into conservatism. When I asked my interviewees, who would be more likely to be labeled as 'religious', men or women, they confirmed that the term was primarily used to define men, not as much women. Gulsen, an Arabic teacher in Samandag, says:

"The religion is taught to men, not women. We only learn about our religion by observing others around us, from conversations, or reading about Arab Alawism. This is not the case for men. Boys go to their Amca and learn everything from them. We don't have that kind of a responsibility. I don't know how to define it, as exclusion perhaps? All I know is that we don't have that responsibility."

Gulsen simultaneously considers women 'excluded' but also 'spared' from religious responsibility. The point I am trying to make is; while Alawite women are subject to patriarchal oppressions, they consider themselves spared from religious pressure. Their religious responsibilities are significantly less compared to men, which "sets them free," as many women put it. They are not obligated to spend months studying and memorizing prayers. They do not have to perform certain religious acts such as namaz or become religious mentors for boys. They don't become sheikhs and are not expected to represent the religion in a formal way. Neriman, a local politician, thinks if women performed namaz, they would have more problems, because they would have increased responsibilities to fulfill. According to Gulsen: 
"Arab Alawite women feel freer than other [Sunni] women, because we don't have a religious responsibility, we have a social and cultural responsibility only... We are included in everything except for namaz. In that sense, we actually have more freedom compared to men. Also compared to other women. This is due to our religion, our religion is more laidback, it is more cultural."

As a matter of fact, many women think they are better off than Alawite men.

"Arab Alawite women are more advantageous than men, because they can choose their own path when it comes to faith," says Yesim, an accountant. She elaborates:

"It's not that I want to become more religious. I feel lucky that I was able to choose my own path. Because religion is not forced down our throats. In the more recent period, the same goes for men. Men don't want to get too involved in the religious aspect either. This is a bad thing maybe, but I think they should also be able choose their own path, just like us women. But the more old-fashioned families are not happy with this. They believe men have to learn the namaz. But many men who go to the university etc., aren't that interested. In a way, this contributes to the extinction of our culture. It is saddening in that sense."

The idea that women are at more liberty to choose their spiritual path also makes some women believe they have a more objective view on religion. Cemre, an educator, thinks that "being distanced from religion allows Arab Alawite women to be freer and look at it from a more scientific perspective".

A crucial point women raise is the difference in 'religious' versus 'patriarchal' pressure. There is a consensus that Arab Alawite women do not experience religious pressure, however they cannot escape patriarchal pressures, like most women around the world. Nurdan says: 
"There is no religious pressure on women. It is true that this sets women free. I feel freer. I am not tied down by our belief system".

After admitting that she is "afraid" of religion in general, Nima, a human rights lawyer told me, "perhaps it is better that women don't learn namaz, it enabled women to be freer, otherwise there would have been more religious pressure on women". Women coming from sheikh families are an exception, however. The daughters and wives of the sheikh have to lead their lives within a stricter framework, since they are in a way representing the sheikh. Their clothing, actions, and words come under greater public scrutiny.

It is important to consider the difference in the wants and needs of women who are secular or atheist, lead a more modern lifestyle, live in urban areas, versus those who have religious faith and live in more traditional settings. While the former group may consider exclusion as a 'blessing in disguise', especially because religion does not play a central role in their lives, the latter group does not view exclusion as beneficial. When I asked Berrin about this perception of 'accidental benefit', she responded:

"I think this is similar to working in mines, where women are not allowed to work, neither are children. So, this mentality, that because I am a woman, people will give me their seats, won't give me hard psychical work, and thus I am more comfortable. This is similar to that. There are certain perks of gender roles, but knowledge is power. Thus not knowing means powerlessness. Ignorance is bliss. If you don't have knowledge, you cannot make a decision or take responsibility. So I don't agree with that statement. I've been in situations where I was able to evade responsibility, but I didn't think it was good or a bad thing." 
The relationship between religious systems and oppression/exclusion of women has been scrutinized. It is certainly no secret that religion has been used as a tool to oppress women worldwide. Ethelia writes, "women seem to be suffering double oppression, from religious misperceptions and male dominance under the guise of religious norms" (2014: 1). Studies show that women's rights have advanced more swiftly in societies where religion does not play a central role, or societies that have strict laws separating religion and state (Carter, 2014). Klingorova \& Havlicek's study on religion and gender equality finds, "states where the majority of inhabitants are without religious affiliation... display the lowest levels of gender inequality (2015: 2). Religion is not only used to oppress women, but also to exclude them in many ways, or to extend certain privileges to men (Ethelia, 2014). In line with these two sets of arguments on oppression and exclusion, Arab Alawite women (those who believe their exclusion benefits them in the long run), argue that exclusion from an oppressive structure in fact empowers them.

When I asked Sheikh Celal about women and namaz, he started off by correcting me by calling the act "prayer" instead of namaz. He then went on to explain that women's complaints about not learning about religion is mainly in theory, and rarely translates into practice. He thinks that with the rise in modernity and material culture, women's interests have shifted from the religious sphere into the social sphere. He applies the same idea to the younger generation. He expresses his disagreement with the saying, “Arab Alawites don't teach anything to their 
women". He says, "if Arab Alawite women want to learn the religion, they can read the Quran, learn the roots of Alawism, there is also a prayer book". He believes a woman can learn anything she wants, as long as she puts her mind into it. This does not mean he ignores their exclusion from namaz, or prayer. He told me, "men and women are equal in our community, the only deficiency is in the transfer of knowledge to women and the youth". Thus, he reframes the problem of women's exclusion, by highlighting the deficiency in knowledge. As a sheikh, he also shoulders part of the responsibility to make religious knowledge more accessible to women. Birgul, a local journalist, agrees with the sheikh, "I think if women really wanted to be a greater part of religion, they could have, I guess they didn't really want to".

\subsection{What do Arab Alawite Women Want in terms of Religion Inclusion?}

During the "Arab Alawite and Women Workshop" at the Arab Alawite Conference, women were given the platform to voice their critiques about the religious, social, and political aspects of the Alawite community. The all-female participants of the workshop did not think they were "overlooked" in Arab Alawism. They agreed that just like any other religious society, Alawism had its share of practices defined by patriarchy. At the end of the highly productive discussions that lasted throughout the day, participants made a series of demands as a group. The final report reads:

"We came to an agreement that women are not overlooked in the religious order, but their role is for the most part limited to service areas, thus hinting 
to a role division in line with patriarchy. We highlighted the importance of women in encouraging visitations to sacred places and their active role in those places. As it can be observed in other patriarchal societies, we discussed that Arab Alawite women are 'ethnic vessels' and their roles as child-bearers is a result of such patriarchal system."

Even though they agreed Alawism was not an exception to the patriarchal system, participants did have a craving for more knowledge. This craving was reflected in their official demands, which were primarily orchestrated around facilitating access to religious information and opening up traditionally maledominated spaces for women's engagement:

"Considering Arab Alawite women have considerably more societal freedom, we ask that they should be allowed in spaces where men socialize to get the opportunity to ask questions to religious leaders about religion, history and culture. We also ask that opportunities for women, who wish to learn more about the existent religious practices pertaining to women... are facilitated."

A significant number of women I interviewed voiced their concerns about lacking adequate religious knowledge. They recounted incidents during which their lack of knowledge put them into a vulnerable position while dialoguing with outsiders. For the most part, when posed questions by a Sunni, for instance, Alawite women admit not always having answers. Such encounters perpetuate the perception of Alawites as "heathens". The first step in ending this cycle, according to many women, is to facilitate teachings in Alawite religious philosophy and history. Birgul elaborates on the problem of knowledge deficiency:

"Not necessarily learning the namaz, but religious leaders should explain or discuss our religion with women. This is our greatest wound. Alawites who 
go to the university have big problems, because they don't always have answers and are judged and questioned. They are called "heathens". We are asked what we believe in. The new generation doesn't inquire much as it is. They are taught namaz, but that's where it stops. I try to teach my daughter's friends what I know. There is a serious knowledge deficiency. This is very important for cultural survival."

Sevgi, who is an elementary school teacher in a primarily Sunni Arab community, says she wishes women were also taught namaz, so that they could defend themselves more efficiently. She recounted an incident at school, which left her embarrassed of her lack of religious knowledge:

"Here in Kumlu, the religion teacher was explaining the sects to kids. The teacher knew I was Alawite and he came and knocked on my door and asked if I could tell the kids in 7/A about Alawism. I froze and told the teacher that unfortunately I didn't know enough about my sect. I redirected the teacher to Sedat, another Arab Alawite teacher. Unfortunately this is what happens."

Women are not necessarily demanding to learn namaz or go through the religious training. What they are asking to be included, and encouraged to take part, in the discussions on their history and belief system. They are tired of feeling powerless when interrogated by outsiders. They want to be able to defend themselves. These women are aware that knowledge and power are integrated with one another (Foucault, 1980) and that without knowledge, they do not feel they have the power to speak up. Gulizar, who studied outside of Antakya, told me:

"When we go to study elsewhere, they want us to protect our identity, but then we have problems defining ourselves when asked by others. We only have general information, that we love Hz. Ali and we consider him the caliph after Hz. Mohammed. There are no details and they expect us to just accept it. 
This is unfortunately only questioned by educated women, even then not much is achieved."

The voices of Alawite women have been partially heard since the conference proclamation. Ahad-Der51 (Arap Halki Alevileri Dayanisma Dernegi), which was founded in Adana in May 2015, is in the process of opening a branch in Antakya. The long-term goal of the association is to establish an Arab Alawite federation. The association aims for the grassroots organization of the Arab Alawite people through self-representation and institutionalization of the Arab Alawite faith, which would include institutionalizing the sheikhs' education as well. More importantly, AhadDer also wants to address the 'women's issue' in Arab Alawism. I interviewed Kerim, son of a sheikh, who is involved in the founding process. He told me about the intended women's studies program, which would provide teachings on Arab Alawite history and belief system. His words were, "we will raise women who really know Alawism and who will have a voice". This is primarily geared towards equipping women with foundational knowledge, so that they can raise a shield to the attacks against their religious identity. Kerim adds, "in our society, women are primarily the ones raising the kids; they need to be more aware". He told me they will facilitate women's participation in the management of the association, even presidency, which is considerably rare in mixed-gender cultural organizations. Ahad-Der wants to be a platform for Arab Alawite women's organizing, and even a women's committee is in the pipelines.

${ }^{51}$ Association for the Solidarity of Arab Alawites 
Ahad-Der did have some backlash, however, especially from the sheikhs. Hilal, a local political activist, who closely follows the establishment of Ahad-Der, told me that many sheikhs were bad-mouthing Ahad-Der already. Some sheikhs were spreading misleading rumors, telling people that Ahad-Der was intending to teach women how to perform namaz. Hilal explained how the involvement of women in Ahad-Der was one of the cornerstones of the association, at least for the Antakya branch.

\subsection{Marriage Matters: Rules of Engagement and the Premise of Cultural Preservation}

Arab Alawites generally pride themselves with being humanist, accepting and tolerant. "We accept everyone, no matter their race, religion, or language," they say often. This has been certainly true from my own experience. They also pride themselves with not believing in polygamy, unlike some adherents of Sunnism. There is one sensitive topic, however, and that is intermarriage. In a multi-ethnic, multi-religious country such as Turkey, intermarriage is bound to happen. Especially with modernization, the younger generation is increasingly picking their own spouses, compared to the more traditional way of matchmaking by the parents. As a multicultural province, Antakya is also increasingly experiencing intermarriage amongst its multitude of ethnic and religious groups. For Arab Alawites, this is an alarming trend, predominantly because of cultural preservation. 
Intermarriage is an important aspect of assimilation that is often neglected (Qian and Lichter, 2007). Even though studies conducted on intermarriage and assimilation focus mostly on immigrant populations, which Arab Alawites are not, they demonstrate the challenges of assimilation and cultural preservation (Caytas, 2012). Intermarriage can be beneficial in terms of economic or social assimilation (Meng and Gregory, 2005), but over time, studies show that in-group marriages drop significantly, or even become rare (see Bugelski, 1961). This can lead to serious cultural erosion, which is the main concern of the Arab Alawite community.

In the first chapter, I indicated how intermarriage was facilitated by the state in the aftermath of Antakya's annexation. This facilitation, which involved cash for weddings, aimed to assimilate the Arab Alawite community (Mertcan, 2014: 213). Therefore, understandably so, until today Alawites do not lean towards intermarriage. It is especially difficult for Arab Alawite women to marry someone from another religion or sect. Gulizar, who got married to a Turkish Sunni, put it this way:

"Intermarriage between religions is regarded a no-no by many people. There are even families who witness other women marrying men outside their religion and that's why they decide against sending their daughter to university. They are afraid that she will fall in love with a Turk or a Kurd."

Several other women confirmed the underlying fear that if a girl goes to another city to study, she will bring home a man from another culture. However, this does not necessarily translate into prevention of girls' education. On the contrary, Alawite 
women are among the highest educated groups, which I will get into further detail in Chapter 4.

Essentially, intermarriage is seen as an obstacle to cultural preservation. For a minority group based on secrecy, cultural survival is crucial. Nilay, mother of two, told me that in Samandag, they don't prefer intermarriage, not just because of cultural difference, but also because of cultural survival. Songul, a lawyer and politician, explains:

"I live in Samandag. Here we have Kurds or Anatolian Alevis who work here. We live all together, but things become stricter when it comes to intermarriage and performing religious rituals. It is still very rare that people intermarry. So, in that sense the walls are still high."

The walls are indeed still high, "even though intermarriage has been on the rise in the past 15 years," Nuray tells me. Ozge, who lives in the Western city of Izmir, tells me her father did not want her to marry a Kurd. Her cousin also married a Kurdish Sunni and the family was against it in the beginning. She explains that it would have been easier if the husband was a Kurdish Alevi, as religious and sectarian difference carries more weight than ethnic difference. To break it down, families would be more accepting if their daughter married a Turkish or Kurdish Alevi, rather than an Arab Sunni. Still, the level of acceptance differs from family to family. For instance, Dima's father is Arab Alawite and mother a Kurdish Alevi from Tunceli. Her father's family never fully accepted her mother as Alevi, which significantly affected Dima growing up. She told me that seeing her mother being 
ostracized by her father's family pushed her towards marrying an outsider, a Turkish Sunni from Istanbul.

The treatment of their daughters by the groom's family is also a concern for Alawite families. Nilda says Arab Alawites do not prefer intermarriage because they are afraid their daughters will suffer at the hands of the in-laws, considering the myriad of negative and false information about Alawites. However, the main concern remains to be cultural preservation, which can be interpreted as an act of 'resistance'. Naciye is a Turkish Sunni woman from Ankara, who married an Arab Alawite. She has an interesting observation on intermarriage:

They [Arab Alawites] are similar to Jews in that sense, they don't want to marry outside of their community, their property to be divided, etc. It could be a form of resistance to assimilation. Perhaps they are right. If I had my current mindset before, I wouldn't 'ruin' my bloodline either, which is 'Nogay Tatar'. Everybody wants to preserve and continue their bloodline. In that sense, I feel like I have betrayed my race. I would have liked to continued my ethnicity."

Naciye explains how even though her husband's family has accepted her, she will never be minnina, which is an Arabic word that means "from us" or "one of us", used frequently by Arab Alawites to refer to a member of their community. Naciye has two sons and she made sure they duly received the religious training. This was a pre-calculated act, she admits, so that they would not be ostracized by the Alawite community.

A participant at the "Arab Alawism and Women" workshop also made sure her sons went through the religious education, even though she identifies as an 
atheist. She sees the religious education as an act of resistance to assimilation and a necessary tool for cultural preservation. A café owner, Cem, thinks the boys' religious training is pivotal. He told me that he did not marry the love of his life, because she was not Arab Alawite. He thinks Arab Alawites need to marry within their community, in order to protect their culture. He ended up marrying an Arab Alawite woman, mainly for this reason. He said, "if you marry outside of your community, what [religion] will you teach your kids?"

Even so, intermarriage is on the rise and women are increasingly choosing their spouses. Sheikh Celal thinks that theirs is the freest society for women in Turkey, in terms of choosing your spouse. Songul agrees;

“In a sect like Sunnism, where people believe that shaking a woman's hand will ruin your abdest 52 , it is men who decide whom the woman marry. Here, women choose and declare whom they will marry."

\subsection{A Perceived Threat to Alawite Women's Social Freedom: The \\ Controversial Figure Mehmet Guven}

Mehmet Guven is an Arab Alawite religious leader from the southern province of Adana. Although his followers are in the thousands, mainly from Adana, he also faces strong disapproval within his community. He is known for making sensational claims, such as predicting that the end of the world will come in 2019 or

\footnotetext{
52 The act of washing parts of the body using water for ritual prayers and for handling and reading the Qur'an.
} 
that he receives messages from Jesus ${ }^{53}$. Aside from his sensational claims, one area specifically is of concern to Alawite women; Guven's conservative views on women. Referring to Guven, Belgin from Samandag says, "there is no religious pressure on women [in Alawism], but I know some people who are connecting moral codes to religious codes". Women are increasingly worried about Guven's imposing of 'moral behavior', seeped in patriarchy, on grounds that it is obligated by religion.

The relationship between morality and religion is very controversial and dates back to the beginnings of organized religion. Societies have often connected moral codes to religious systems to control certain populations, such as indigenous populations and women (Stannard, 1993). Even during times when religion intertwined with racism, it was constructed on 'moral' grounds. These socially constructed moral codes, framed as “God's will", often created a binary between what is moral versus immoral, as if they were absolute facts. Whether or not religion makes us moral, or if religion is necessary for morality has been a hot debate within secular societies (McKay \& Whitehouse, 2015). Women's bodies frequently become sites of morality and immorality, which men try to control. Within Sunni-Hanefi Islamic tradition, women's morality is often measured with the headscarf, religious piety, and limited interaction with the opposite sex. Within Arab Alawism, things are different. For one, women are not expected to cover their head, unless they are entering a ziyaret, and women and men often socialize together.

\footnotetext{
53 There are numerous articles on Guven's predictions in local newspapers; see cukurovapress.com
} 
Belgin explains how Guven is introducing Sunni gender codes into the

Alawite community:

"My mother is from Adana and there is this man Mehmet Guven. When we were in Adana, we wanted to visit a ziyaret, but they didn't allow us to go in, because there was a kids Quran course and there were men inside, so we had to wait until they were outside. This is the mentality of Sunnis, the division between men and women. This man is trying to impose this on us. I was so taken aback and told my mom I wanted to go in. I am a believer and I wanted to go in and pray, but they didn't let us inside. So a handful of men are telling us about religious codes that are also supposed to be moral codes. Mehmet Guven also has a branch here, in Armutlu. I knew this guy and he changed, he doesn't shake my hand. But this is so new and it's not everywhere. This could be something to Sunnify Arab Alawites. This is very worrisome. My aunt thinks that rocks will rain on us, if we wear short sleeves. If something bad happens to us, she says it's because we don't believe him."

Efforts to Sunnify ${ }^{54}$ Arab Alawites (and Anatolian Alevis) is not new. Building mosques in Alawite neighborhoods and introducing Sunni religious elements in education dates back to $17^{\text {th }}$ century (Talhamy, 2011), perhaps even before that. With the rise of Sunni-Hanefi Islamic ideology in the political and social realms since AKP came to power in 2002, secularists, as well as Muslim and non-Muslim religious minorities, have increasingly been feeling marginalized. Even though AKP has initiated efforts to reconcile with certain minority groups, as part of its bid to the European Union, these efforts fell short. For example, AKP initiated the Alevi Opening ${ }^{55}$ with the intention of resolving Alevi problems and demands, AKP's fear of

\footnotetext{
${ }^{54}$ Sunnify means 'to make Sunni' through different methods including education, intermarriage, coercion, etc.

55 The Alevi Opening was geared towards Turkish Alevis (not Arab Alawites) and aimed to settle the grievances, particularly regarding the recognition of their
} 
"offending the Sunni-Hanefi segments of its electorate and... causing alienation within its party ranks" has cost them the trust of the Alevi community (Bardakci, 2015).

The Alawites that I met, men and women, take great pride in their culture that enables women and men to socialize together, drink together, and dance at weddings. Whereas in the more conservative Sunni communities, there is a gender division while socializing, men and women do not shake hands unless they are related, and consider it a sin to consume alcohol. Women expressed their concern about Guven at the Feminism Camp 56 in Mersin as well. They pointed out how he is putting religious pressure on women, saying they should cover up, that girls should not go to school or marry Turks and Kurds. Apparently, Guven has also made remarks on Arab Alawite women being "deviant" and "loose". His conservative and misogynist discourse against women met resistance in Antakya, however.

During a house visit in the village of Tekebasi in Samandag, which is considered one of the more conservative Alawite villages, the family eagerly told me how Guven was trying to recruit followers here. The father explained:

“Mehmet Guven's followers are mainly in Adana and Mersin, but they exist here, too. Every Tuesday they have dinners and try to recruit people. Whoever is a bastard, a crook, a filth goes to him. He says that girls need to cover their heads."

worship sites (Cemevi), changes in the compulsory religious education based on Sunni-Hanefi Islamic ideology, and the status of the Directorate of Religious Affairs.

${ }^{56}$ I participated in the annual Feminism Summer Camp organized by Kadin Emegi Collective in October, 2015. 
Alawite women are resisting such oppressive ideology though daily, 'informal' acts. I would like to refer to Cope's method of looking at "ways in which women have actively created new or different space for political action, which can enable them to engage directly with mechanism of oppression and provide a base from which to directly intersect the state" (Cope, 2004: 71, in Staeheli, Kofman \& Peake). Using their bodies as political grounds within familial structures, many women are resisting state and patriarchal efforts to control women's bodies. For instance, the daughters told me that one of their uncles pressured the daughters-inlaw and girls in the family to wear long dresses and long sleeved shirts. The daughters-in-law told him once he starts wearing traditional clothing like shalwar ${ }^{57}$, long sleeved shirt, jacket and hat, they would do as he pleased. The daughters ended the story with a chuckle and said their uncle eventually gave up on his endeavor. The family has little doubt that the Guven movement is a project aimed to divide the Arab Alawite community. According to them, Guven recruits followers by distributing cash. Some believe he can fly. Regardless of the religious and spiritual aspirations of Guven and his followers, one thing is certain: the Guven movement is 'messing with gender' in the Alawite community. And Alawite women are not happy about it.

57 Traditional baggy pants, similar in style to pants known as "MC Hammer pants" in American culture. 


\section{CHAPTER 4: Process of Politicization in Antakya: Arab Alawite Identity, Leftist Movements, and Women's Involvement}

"In this country, to be a woman, to be Alevi (Alawite), and to be working class is so painful. They will make you pay for it." - Burcu, teacher and socialist feminist

In order to understand the rise in women's political consciousness within the Arab Alawite community in Antakya, we must first investigate the roots of the political platform that not only allowed but also encouraged women to be part of the politicization process. To do so, we must gain a basic understanding of the political climate on the national and local level since the annexation. Therefore, this chapter will lay out a blueprint of the political climate during the Republican era and trace how national politics played out in Antakya. My goal in this chapter is to locate Arab Alawites' political tendencies, which have been largely leftist and socialist, examine the causes behind their increased inclusivity of women in the political sphere, and to better understand how the Arab Alawite 'public' identity has evolved since they became Turkish citizens.

Drawing on existing literature by Arab Alawite scholars, I will begin by exploring the political identities among the Arab Alawite community. These scholars point out the fact that historically speaking, Arab Alawites have reinforced their public identities through political expressions and affiliations, rather than their ethnic and sectarian background. They also stress the importance of the class-based and secularist approach of leftist and socialist movements, which was a source of 
relief to many minority groups, including the Alawites. I will then introduce several narratives of women who became politically active through the leftist and socialist platform. Their powerful stories, dating back the 1970s, help understand the experience of gender within these movements. The following section will discuss the Republican People's Party's (CHP) popularity among Alawites and why the People's Democratic Party (HDP) has been receiving increased support from Alawites. I will end the chapter with an analysis on the Syrian Conflict and Occupy Gezi Park protests, arguing that these incidents have caused a political shift within the Arab Alawite community in Antakya. I will illustrate how the Arab-Alawite identity, which has been at times brutally suppressed since the annexation, and especially after the 1980 coup, is now experiencing an 'awakening'.

\subsection{Political Articulations of Arab Alawite Identity: Leftist and Socialist Tendencies}

Can (2011) argues that religious concealment is a method of resistance to assimilation among the Arab Alawite community. According to Can, in the struggle of preserving their ethno-religious identity and their religious secret, the only 'safe' way for Alawites to be visible in the public sphere has been through leftist political identities. They have shied away from ethnic and religious discourses and have inserted themselves into the conversations around the broader Alevi minority and leftist politics (Can, 2011: 65). Can provides the example of the annual Evvel 
Temmuz Festival ${ }^{58}$, held in the district of Samandag every July. The festival was banned after the 1980 coup, but revived with the efforts of leftist politicians and activists in 2000. Instead of being a space for religious discourse, the festival is a stronghold of anti-imperialist, feminist, leftist, and pro-Arab discussions. In short, aside from celebrating their cultural heritage, the festival has become a political space, with strong references to leftist and socialist ideologies. To illustrate, here are some of the activities held during the 2014 Evvel Temmuz Festival:

July 6, 2014, 10 am: Arabic song competition

July 7, 2014, 9 pm: Arabic theatre

July 10, 2014, 4 pm: Panel discussion on "Political Climate in Turkey" with speakers such as Tuncay Yilmaz, then co-president of Socialist Refoundation Party (SYKP), and Figen Yuksekdag, co-president of HDP

July 12, 2014, 2 pm: Forum on "A fresh breath of air in the struggle of the peoples: Arab Alawite Youth Movement"

July 12, 2014, 4 pm: Forum on "Gezi Resistance on its first-year anniversary" with speakers such as the families of the 'Gezi Martyrs'

July 14, 2014, 1:30 pm: Women's Panel on "Violence? What is that?"

July 14, 2014, 5 pm: Panel on "The Middle East and Syria" with speakers such as Leila Khaled (the Palestinian airline hijacker)

There are two important questions that arise at this point. First, why have Arab Alawites felt the need to conceal their ethnic and religious identities after the annexation? After all, they had become Turkish citizens. The preceding chapters described the ways Arab Alawites have been marginalized during the Ottoman era.

\footnotetext{
${ }^{58}$ Evvel Temmuz coincides with July $1^{\text {st }}$ in the Julian Calendar and July $14^{\text {th }}$ in the Gregorian Calendar. It is an ancient celebration of the yearly harvest.
} 
Feminist theorizations on citizenship and the nation-state will help analyze Arab Alawite marginalization during the Republican era, namely after Antakya's annexation in 1939. Second, why have they steered towards leftist and socialist ideology? To answer this question, I will rely on historical accounts and narratives from the field.

This discussion is a valuable addition to feminist literature on nation-state and citizenship, as it analyzes an event through which national borders 'jumped over' a population from one day to the next and provides an opportunity to observe citizenship-making at its finest. Furthermore, it extends feminist scholarship on women in the Muslim Middle East and the debates around their rights, freedom, and agency (Abu-Lughod, 2002; 2010; Secor, 2001; 2004; 2007; Caglayan, 2008; Ozkaleli, 2009; Gokalp, 2010; Mahmood, 2012; Clark, 2013). Finally, it builds on feminist geopolitics through paying attention to Alawite women's political agency (accelerated by leftist movements), collapsing the public/private and formal/informal binaries when talking about (women's) political acts, and showing how political action on multiple scales inform one another (Hyndman, 2004; Pratt and Rosner, 2006; Mountz and Hyndman, 2006).

After Antakya's annexation in 1939, Arab Alawites became Turkish citizens. As Turkish citizens, they were to be treated equally and enjoy the same benefits as the hegemonic group, the Turkish-Sunnis. This has hardly been the case. In addition to being subject to anti-Arab sentiments, they have been labeled as 'deviants of Islam'. Throughout the Republican era, there have been bans on their mother- 
tongue, their religious celebrations, and certain cultural expressions (Mertcan, 2014; Yilmaz, 2013). During the single party system, with CHP being the only political party, President Inonu had banned Arabic and traditional Arab clothing (Mertcan, 2014: 254). Alawites worried that Inonu would either get rid of them or expel them to Syria (Mertcan, 2014: 257). They had to hide their ethnic and religious identity, which has been an agonizing and inhumane process. In short, the single party system under CHP was an oppressive period for Arab Alawites. Therefore, when the Democrat Party (DP) was founded in 1946, it received wide support from minorities, including Alawites (Mertcan, 2014: 238). DP became an outlet for their frustrations with CHP. When DP came to power in 1950, minorities were rewarded. During DP's government from 1950-1960, despite the Islamization of the education system, the Arabic ban was lifted and there was increased religious freedom (Mertcan, 2014: 230). However, the second term of DP turned out to be increasingly anti-democratic and disappointing for many, including the Alawites (Mertcan, 2014: 271).

The first coup d'état occured in 1960, by a leftist-oriented fraction in the military. With the 1961 Constitution, the basis of the state was founded on human rights for the first time (Mertcan, 2014: 274). Increased individual, religious, and political freedom was established. Between 1960 and 1970, social movements were on the rise, labor unions were formed, and the Turkish Labor Party (TIP) was founded. In 1971, a second coup was carried out by right-wing military officials. Even so, in the 1970s leftist movements continued to flourish, resulting in political 
parties as well as illegal organizations (Mertcan, 2014: 277). Many minority groups, including Arab Alawites, aligned themselves with leftist movements in the 1960s and the 1970s.

Moving on to the second question; why leftist ideology? Marginalized groups often find relief in class-based social and political approaches, because of their indifference to ethnicity, race, religion, and gender, at least in theory. As a group that has been doubly oppressed on religious and ethnic basis, Alawites organically aligned themselves with secularist, leftist and socialist movements and found a platform to voice their grievances and demands. Thus, as Mertcan (2014) and Can (2011) infer, Arab Alawites construct their 'intimate' identity over ethnicity, religion, and language, while their 'public' identity is constructed over class, gender and political affiliation, such as feminism, socialism, leftism, Kemalism, humanism and democratic values (Mertcan, 2014: 309). Can (2011) makes a similar inference by distinguishing between the "inside" and "outside" spaces of identity construction and expression. The 'inside space' is used for ethno-religious articulations, while the 'outside space' is used for political articulations (Can, 2011: 68-69). While a feminist geographic analysis would push against this notion of private/public articulations, I think what both authors are trying to relay is that for a very long time Alawites did not feel comfortable (even felt fear) revealing their faith to non-Alawites. However, as I will discuss further below, certain events in the region started a shift in this perception and has empowered Alawites to express their religious identity more openly. 
Yet another reason for the gravitation of Arab Alawites towards a class-based struggle is their history as a disenfranchised, low-income group. In her article on the Protestant missionary activity in the Alawite territories during the 1800s, Talhamy writes;

"Again in 1847 a similar request was sent by Reverend George Whiting to the Board asking them for their approval to open a station in the Nusayri districts, emphasizing the fact that 150,000 or 200,000 of these most miserable, ignorant and forsaken, most degraded and needy people, who were outcast and oppressed, without books, schools or guidance of any kind, had already professed willingness to receive missionaries and to send their children to school. According to Whiting, 'the Nusayris are perishing like the beasts of the field, with no one to think of or care for their souls, and it is the duty of the American church to take thought for them and send some of her sons and her daughters to preach to them the blessed gospel and gather them into the fold of Jesus'. During the same year Dr. Yates and his wife, who had settled in the vicinity of Swedeyah ${ }^{59}$, opened a school for the children of all the religious minorities. According to Edward Barker, the British consul, they managed to establish in that region a Protestant community that included ex-Greek Orthodox, ex-Muslims and ex-Nusayris." (2011: 221)

While the tone of the missionaries might come across as 'melodramatic', the truth is Alawites had little to no access to education, property, and employment, other than working on the land of the wealthy. In his book, Duman states that leading up to World War I, Arab Alawites constituted the poorest and least educated group in Antakya (2016: 58). He also writes that almost all land in the Asi Valley, which has the highest Arab Alawite population, belonged to Sunni aghas. The agha system had placed Arab Alawites at the bottom of the socio-economic ladder. Nuray, previous political and feminist activist, agrees, "There is the economic factor: economic

${ }^{59}$ Swedeyah is the Arabic name for Samandag. 
means were in the hands of the Sunnis, since land-agha system was common and Arab Alawites used to work for the Sunni aghas. They were very poor and oppressed".

Feminist activist and socialist politician Leyla describes the historical connection of Alawites to peasantry;

"The socio-economic aspect of it is the fact that Arab Alawites used to be a poor society and they used to work in fields and that's why were called 'fellah'. Fellah is sometimes considered a religious labeling, but Alawites don't accept that, it was just an occupation. Once the doors to Arab countries opened up, especially Saudi Arabia, people began migrating for work and Alawites prospered financially, especially after the $1970 \mathrm{~s}$.

It is for these reasons, among others, that Arab Alawites were attracted to leftist and socialist struggles and have accessed tools to resist systemic oppression. Alawite resistance is also often referenced to Caliph Ali's fight for justice. Nuray elaborates, "Alawites are expressing themselves within the leftist movement and are revolting against injustice, which dates back to Caliph Ali and the injustices he suffered". Alawites highly revere Caliph Ali, who experienced a series of injustices and fought against the dominant ideology of his time. Hakan, a local musician, believes that this is engrained in the collective memory of Alawites, making them "naturally" resistant and side with the oppressed. When probed, this explanation was often used as a justification for joining leftist and socialist movements.

Politicization starts at an early age among the Alawite community in Antakya, for both young women and men. In line with the reasons explained above, Alawite 
youth is primarily drawn to leftist and socialist organizations. Tahir, a leftist political activist who served twelve years in prison, tells me that he began searching for an identity and class consciousness in elementary and middle school. He was in high school during 1974-75 and found himself in the midst of the leftist struggle, going from one meeting to another, distributing pamphlets, and reading books. According to Tahir, after the 1971 coup there was a search for identity and "people were asking themselves, 'why are we in this situation?'” The search was both on the individual level and the societal level, especially among the working class, students, and the youth. When the Dursunlu People's Association was founded in his village in 1977, he joined the initiative. Since the word 'people' was banned, they changed the name to Dursunlu 'Cultural' Association. The association drew workers and students, staged plays, held panels and weekly discussions, and helped unionization efforts. Tahir believes that the process of politicization during those years eventually enabled Arab Alawites to express themselves on a religious and cultural basis later.

During the period between 1975-1980 the right-wing nationalists were very active. The Left was also organizing and drew in people from different religious backgrounds, such as Sunnis, Alawites, and Christians. Their struggle was classoriented, not identity-oriented. A political activist since his teens, and a communist at heart, Devrim believes that nobody should engage in politics based on their belief. He says, "I construct my Arab Alawite identity from a cultural aspect, not religious, and as a revolutionary person, I support a movement that is against the current 
system, no matter what the ethno-religious background is". Arab Alawites were the majority in the leftist movement in Antakya during the 1970s, "because of their oppression throughout history", says Tahir. The growing pressure on Arab Alawites during that period resulted in the inability to openly say, "I am Alawite". Still, they found opportunities to resist, such as a book burning protest during religion class, where they burned their textbook that was insulting Alevis.

Mahir, the director of one of the largest left-oriented labor unions, was in high school soon after the 1980 coup. He describes his family as 'political', where everyone speaks out, especially his mother. His older brother was the head of the Iskenderun Iron-Steel company union leading up to 1980. Mahir took his older brother as an example, who approached issues from a class perspective. His brother fought for the rights of all employees, including the ultra-right-wing. When he was sentenced to prison with the 1980 coup, it was the right-wing employees who helped Mahir and his family track down their brother. Mahir says;

"Back then, political organizing was more based on class, the struggle of working class. We were trying to find solutions to bring working class people of all backgrounds together. Our generation had the highest university graduates."

Mahir was not in a political organization during his university years. Because he had a class-based approach, he did not get involved in the leftist-rightist conflict. He told me: 
“When Harun Karadeniz ${ }^{60}$ was organizing garlic growers, he didn't ask them whether they were rightist or leftist, but saw them as farmers. You need to build relations with all poor and oppressed people. My brother, as a leftist, worked together with rightist people when it came to labor. In order to transform a person, you need to connect with them, you cannot transform anyone by fighting them. People called me 'liberal', an 'opportunist', not 'leftist'. They used to tell me, 'what kind of leftist are you?' Even though you identify differently, you need to use a common space. We were all hungry, all in the same boat. I saw the need to connect with people, even though they didn't think like me."

There were indeed fractions within the leftist movement. Not everybody agreed on ideology or strategy, and sometimes personal issues got in the way. Devrim tells me that before the 1980 coup, the different leftist organizations in Antakya fought each other during the day and kept watch together at night. Hence, even though they had their disagreements within, they kept a united front. While Sunni-Alevi and rightist-leftist conflicts were abundant on the local level, they did not get out of hand. For example, following the 1978 Turkish Alevi massacre in Kahramanmaras, a similar tragedy was expected in Antakya. Devrim says the state armed Turkmen villages and tried to instigate violence, but was unsuccessful. The locals remained level-headed and such provocation was prevented (Mertcan, 2014: 292-293). Tahir adds:

“There weren't massacres here like in Maras, because leftist organization prevented this. Shop keepers and schools did a boycott and 15,000 people marched. This is how fascist massacres were prevented. The government back then were instigating massacres. Rising societal opposition were tried

${ }^{60}$ Harun Karadeniz was a Turkish political activist and author. He was the student leader of the late 1960s generation in Turkey and the chair of the Student Union of Istanbul Technical University. 
to be suppressed with paramilitary forces. Everybody was arming themselves, even the common citizen".

The 1980 coup was headed by General Kenan Evren, Chief of the General Staff. The events surrounding the 1980 coup have sent thousands to prison and cost the lives of several hundred, including Arab Alawites. The trauma caused from the involvement of Alawite youth in the leftist struggle has created an apprehension among that generation, who do not feel comfortable expressing their ethno-religious identity openly. A local singer, Sevgi, recounts an incident where she was warned by her friend not to reveal her Alawite identity in a Sunni circle:

"I remember this one time, we were sitting in a large circle and I said I listened to Ilkay Akkaya ${ }^{61}$, upon which my friend stepped on my foot and whispered, 'shush, there are Sunnis at this table'. I wondered if Sunnis don't listen to Ilkay Akkaya. I guess my friend had the logic that leftists are usually Alevis. I think this was in middle school. She had said, 'd on't tell them, they are not like us'. I wondered, who are they and who are we? But if you grow up in a village, then this wouldn't really happen. In the city, it is more mixed. The teachers didn't discriminate, but students had begun talking about who is Alawite and who is Sunni. And then in Istanbul it became more of an issue."

Still, Antakya remains a stronghold for leftist and socialist political organizing. I have met politically active youth, from ages 18-30. The conversations within these young leftist/socialist circles are extremely critical and show a high level of socio-economic and political consciousness. For example, during one of my field days with SYKP youth, a 26-year old Alawite male from the group told a CHP councilwoman that he supports her, especially because she is a woman. "I am also a

${ }^{61} \mathrm{~A}$ famous Turkish folk music singer, who openly expresses her leftist political orientation and is one of the founders of the Green Party. 
feminist," he adds, upon which a discussion on 'can men be feminists' begins. The same young man also brought up polyamorous relationships, which was followed by a conversation on the construction of marriage as a capitalist institution and whether monogamy was 'natural' or not. The group, in which males were greater in number, constantly kept each other in check when it came to gender-sensitive vocabulary and patriarchal expressions.

Like many others, Tahir says leftist organizations have higher gender equality compared to other political organizations. Selda, a lab technician, tells me that a crucial part of Alawite women's increased freedom stems from the long involvement of Alawites within the leftist/socialist movement. An increasing amount of Arab Alawite women are finding their voice within the leftist/socialist platform. Even if they are not formal members of organizations, they align with the Left. Yesim, an accountant, explains;

"I am not politically active, I don't want to be a member of any organization. I prefer to be independent, but of course I am on the Left. I don't want to be tied to any organization, because no matter where you are, there is a hierarchical structure, even within leftist organizations. I don't like that."

Ceren, a lawyer and human rights advocate, participated in protests with student organizations during her university years and expressed herself within the leftist movement. "I become revolutionary through books," she says. She believes going against the system, resisting, and not accepting oppression is "in her genes" as an Arab Alawite. She does not feel the need to be in a separate women's movement, 
because, "the leftist/socialist movement already encompasses women," which is sufficient for her. She expands;

"During the university, I was very active in clubs and organizations. Of course I always expressed myself within leftist groups. If a person from Mugla ${ }^{62}$ goes to the university, they don't go as a revolutionary, but if you are from Antakya, and have especially been in leftist circles, you go to the university well prepared. I don't remember the exact time I was politicized. My family is very democratic and always discussed leftist politics. My brother had a big influence on me. He gave me Little Black Fish to read, and other books. I learned that the struggle is against the system and the feudal system. So, you begin to oppose dominant structures and question the world. You learn that you don't have to abide by the dominant structures. I think CHP also had an effect on me, because it's been the opposition. Reading the classics also taught me about socialism, such as the Russian classics. I was amazed by socialism."

From Ceren's statement, we can see how the 1980 generation had a strong influence on the younger generation, whether it was through family ties or through books. Burcak, another lawyer and human rights advocate, tells me her political awareness began to rise during middle and high school, due to her family. Once she arrived at the university, she almost immediately found leftist associations to join. In the following section, I will explore the stories of leftist/socialist women in more depth.

\section{2. "I am a teacher, a woman activist, and a mother": How the Leftist Movement Politicized Women in Antakya}

In Freedom for Women: Forging the Women's Liberation Movement, 1953-

1970, Giardina writes that the Civil Rights Movement and the Left political establishment were a "catalyst" for feminist activists. Contrary to the widespread

${ }^{62}$ A province in Southwestern Turkey. 
belief that it was the Second-Wave feminism that organized women in the 1950s and 60s, she argues that being the offspring of First-Wave feminists, these "daughters of the Old Left" already had a feminist consciousness. They had grown up learning about family members' history of political involvement. Giardina claims that both the Black Freedom Movement and the Left provided a platform for the founders of Women's Liberation Movement to polish their activism and leadership skills, which would have been difficult outside these movements at the time.

We see a similar scenario in Turkey in the 1970s, when women became activists through leftist movements. In the case of Turkey, the Left was more oriented towards communism, as "social movement organizations were dominated by various socialist, Marxist organizations, including women's organizations," write Ozcurumez \& Cengiz (2011: 24). The authors focus on the Progressive Women's Association (PWA) founded in 1975 within the framework of the Turkish Communist Party (TKP), and claim that "the PWA represented a milestone for women's organizations in the 1970s in Turkey" (2011: 24). Drawing close to 20,000 members, primarily recruited from the 1970s labor movements, the PWA is said to have organized the largest number of women in Turkey (Ozcurumez \& Cengiz, 2011: 24). The PWA did not define itself as a 'feminist' organization, but was "traditional Marxist feminist" (Ozcurumez \& Cengiz, 2011: 24). The authors quote Tekeli (1990), that the PWA did not have a feminist outlook, however most feminists "came from various lines of the socialist left" (2011: 24). The founding members claim that PWA was not directly linked to 'the woman question', but was rather "established for the 
sake of strengthening the TCP" (Ozcurumez \& Cengiz, 2011: 24). The PWA ceased to exist after the 1980 coup, due to the nationwide clampdown of the leftist movements.

The 1980 coup is considered the milestone in the feminist movement's history in Turkey, as "the post-coup period witnessed the emergence of organizations that defined themselves as 'feminist' for the first time" (Ozcurumez \& Cengiz, 2011: 24), as opposed to just 'leftist and socialist women'. İlkkaracan (1997, in Ozcurumez \& Cengiz, 2011: 24) claims that the feminist movement in the postcoup era was the first 'new social movement' that had the courage to voice demands and organize marches.

Based on the assessment of scholars, who have studied the intersections of the Left and feminism in Turkey, we see that, "the most renowned names of the feminist circle have been members or sympathizers of leftist parties and organizations" (Akal, 2001: 479, in Ozcurumez \& Cengiz, 2011). Antakya is home to some of the older Marxist and socialist feminists of the 1970 era, as well as the daughters of the "Old Left". Feminist activist and president of Antakya's Samandag Women's Solidarity Association, Bahar says:

"In this region, there is a strong presence of leftist women's organization... Leftists don't have a culture that blindly follows orders. There are feminist uprisings among the leftist movement here, too. When we have a certain event, a memorial etc., we can easily access women, for example. We collaborate with academics. But we don't forget important dates (for women) and commemorate them. Most of the leftist movement here includes Arab Alawite women, but I don't want to categorize it like that, we have women from all backgrounds. We believe that the 'woman's question' is a universal 
problem. It is a problem above and beyond identity and sect. Because whether you are African, Arab, European, you are still oppressed, this doesn't change. We might look at politics from a leftist viewpoint, but a rightist or Islamist woman also is my concern. The state is masculinist. The legal framework as well".

Bahar tells me that her interest for the women's movement began at the university, more on the theoretical level, as she was reading extensively. It was not until she was in the field, 'doing' politics, that she became part of women's activist efforts. She started researching feminism, she went to feminist talks and panels, and she immersed herself in feminist thought. Like Bahar, many women were introduced to the feminist movement through the leftist movement. Selda proves to be another example:

"After I became organized, I began being interested in women's issues. My family comes from a socialist tradition, my father was pro-CHP. I learned primarily from my father, but then I began disliking it. What I had learned was that a separate women's movement would disrupt the socialist movement. But when I met Amargi63, I realized what a nonsensical idea this was."

One of the pioneers of the Progressive Women's Association in Antakya, Burcu's interested in the leftist movement peaked while she was teaching in Antalya, late 1960s. She began reading banned pamphlets and books. She recounts the founding of the PWA:

${ }^{63}$ Amargi is a feminist journal, founded by a group of leftist \& socialist women from Istanbul, Adana and Antakya. The journal aimed to raise consciousness through readings, discussions, panels, seminars etc. and offered legal \& psychological support free of charge. After 6 years, Amargi transformed into Kadin Emegi Kolektifi (Women's Labor Collective). 
"Behice Boran ${ }^{4}$ from TIP (Turkish Labor Party) used to come to Antakya and support us. She used to say, 'girls, I trust you, you will do great things'. She was a professor. She used to tell us to resist. In TIP's office, there was a huge banner that read, 'neither America, nor Russia, independent Turkey'. The neighbors couldn't establish a connection between these three countries, they were confused. Around that time, we were trying to establish PWA. They said they had founded it in Istanbul and asked if we wanted to found the first branch here. I got married in 1973 and PWA was founded in 1975. The main office was in Istanbul and Antakya was its first branch. But we didn't know what we were doing. We had asked an old man for his chairs and he asked what we would do with them. We said we were going to raise women's consciousness, upon which he said, 'and what will happen then? Will they not cook anymore? Will they not raise the kids?' We said, 'women will cook and raise kids, but they will not take a beating anymore'. Women for the first time went on the streets in Antakya and wrote slogans on the wall; 'down with this and down with that!' Every year we would rent a bus and go to Istanbul for the May $1^{\text {st }}$ March. In 1977, we went and all the women got lost in the havoc. We didn't know how to find each other and none of us knew the city. Finally, we managed to get the group together by midnight in Harem, all bruised up and hair messed up."

From Burcu's narrative, we see that women of the 1970 era were still exploring their feminist identity, not straying too far away from Marxist and socialist theory. Many organizations sprung up as "women's branches" of leftist and socialist organizations. These women's associations were effective in recruiting women in Antakya. Burcu tells me the PWA organized a women's protest in 1979 and drew 800 women from villages. It was such a success, that it attracted international attention and they made the cover of a British magazine. Burcu explains the activities of the PWA:

"We were meeting secretly in homes with other women. I organized literature courses and even gave certificates. Workers needed a diploma back

\footnotetext{
${ }^{64}$ Behice Boran was a Turkish Marxist politician, author and sociologist. She was the last president of the Turkish Labor Party (TIP).
} 
then and PWA had opened courses. Nurgul and other women are also doing this today, they have literature courses, these new women's movements. Our first slogan was 'childcare', we didn't even know what it meant back then, we learned it. Our second slogan was 'literacy'. Why weren't girls sent to school? PWA also got involved in this. We gave literacy courses to workers for 50 days and got diplomas from the ministry of education. We followed up with the whole process. I saw my kids only at nights. This was before the 1980 coup".

The first women's organization in Antakya was PWA, soon followed by the Revolutionary Women's Association (RWA), founded by Nima, a human rights lawyer, and her friends. At times, PWA and RWA quarreled with each other, but mostly they worked together, according to Burcu:

"We helped Nima and RWA with setting up shop and all. And then People's Liberation Party-Front rented the space above us, Naciye and them. They didn't believe in a separate women's movement. They accused us of going against what Dimitrov ${ }^{65}$ said. But we were reading all the literature and he had said women can organize separately, as women have different problems. So, we told them this is what it says, but they accused us of trying to divide the movement into male/female. One day we came to our office and they had gone on a rampage. We had gotten through so much trouble to get our furniture and now it was all destroyed! The police asked us if we were filing a complaint, we couldn't because they were also revolutionaries. But we threatened them so that they would at least replace our chairs. There were so many fractions, followers of Deniz Gezmis ${ }^{66}$, of Mahir Cayan ${ }^{67}$, everybody has

65 Georgi Dimitrov was a Bulgarian communist politician and the first communist leader of Bulgaria, from 1946-1949.

${ }^{66}$ Deniz Gezmiş was a Turkish Marxist-Leninist revolutionary, student leader, and political activist in Turkey in the late 1960s. He was one of the founding members of the People's Liberation Army of Turkey. He was executed in 1972.

${ }^{67}$ Mahir Çayan was a Turkish politician and the leader of People's Liberation PartyFront of Turkey. He was a Marxist-Leninist revolutionary leader. On 30 March 1972, he was killed by soldiers with nine friends in Kizıldere village. 
their own journal, arguing it's the best. And among all this, we are trying to organize women and peasants".

Burcu mentions out some of the points of tension within the communist structures, pertaining to gender, and the constant negotiation between socialism and feminism:

"The revolutionaries said that women shouldn't wear miniskirts, they shouldn't marry on basis of love. We followed all these rules, tried to fit the mold. Nuray fell in love with her husband and all hell broke loose. She was in the Progressive Youth Association and we said, 'Nuray, how could you do this to us?' She got a lot of pressure to separate. So, we are learning socialism in practice, not even realizing we were also serving capitalism. Then someone said 'sexual revolution', we didn't understand what that meant. She said it meant women could be with whomever they wanted. This woman from Ankara said, 'my body, my choice', and sexual freedom. This was after the coup. It was the Second Wave-feminism. But if we adopted this view, people would call us indecent. I also wasn't in line with that. I raised my daughters to be modest, not to show their body. But we didn't realize we were under the influence of capitalism. I read a book by Alexandra Kollontai68, where she opposed Lenin and said, 'I can do whatever I want'. How dare she oppose Lenin? [laughs]. People were collecting signatures to have her thrown out. Some of our women friends were on her side, some of them not".

Nuray was twelve years old when Deniz Gezmis was murdered. She didn't eat for 3-5 days. She grew up reading Dostoyevsky and Hugo and she was always supporting the underdog in books. She had a solid class consciousness when she was fifteen and became the secretary for PWA when she was only sixteen. She was at the university during the 1970 s and she had three roommates. The first night, one of them said something negative about Alawites, but Nuray did not react. Since she

\footnotetext{
${ }^{68}$ Alexandra Mikhailovna Kollontai was a Russian Communist revolutionary, first as a member of the Mensheviks, then from 1914 on as a Bolshevik. In 1923, Kollontai was appointed Soviet Ambassador to Norway, one of the first women to hold such a post.
} 
was in an organization and aware of identity politics, her gut told her not to reveal that she was Alawite at that moment. Six months later, she told people that she was Arab Alawite during a study session and an ultra-nationalist girl attacked her. Nuray says during that time, everyday 1-2 bodies would be taken out from the faculty of medicine.

Union organizer and teacher Naciye, a Turkish-Sunni from Ankara, married an Arab Alawite in Antakya and found herself in the midst of the rightist-leftist conflict. She and her husband were members of the People's Liberation Party-Front, the armed faction of the People's Liberation Party:

"Before September $12^{69}$, there was an intense political climate and Turkey was divided into A and B. And we found ourselves in this struggle. My union directorship began at that time. The fact that I was always on the front lines really bothered my husband's family, so they wanted me to take the back seat. Perhaps they were afraid for my life, because I received numerous death threats, they wrote TRB (Turkish Revenge Brigade) on the union's door. I only recently retired as the branch secretary, after 18 years of union work. My youngest son used to say, 'I am going to bomb your union', because I used to spend more time at the union than at home. But my husband shared responsibilities with me, he was helping me with everything. Thinking in terms of gender roles, I mean housework was not only my job".

While Naciye was part of an organization that did not believe in a separate women's struggle, she had a strong feminist consciousness and often challenged the patriarchy within the organization. In the aftermath of the 1980 coup, she refocused her energy into unionizing and the women's movement. She agrees that

${ }^{69}$ The 1980 coup is often referred to as "September 12", as it happened on September 12, 1980. 
Antakya is a stronghold for women's organizations, but makes a distinction between them:

"There are also liberal, modern, Kemalist, nationalist associations and charities. These are more elite, they are Sunni, Kemalist. They are also fighting in their own arena. But leftist women are the feminist ones and you can really work with them, you can go on the streets with them, you can find solutions to women's problems. So instead of ballroom events, the leftist/socialist organizations take on the streets. Within these groups, there are Halkevleri (community centers), Mor Dayanisma (Purple Solidarity), Kadin Emegi (Women's Labor), Sosyalist Kadinlar (Socialist Women), AkaDer (Anatolian Culture and Research Association), Kampus Cadilari (Campus Witches), these are all part of the Antakya Kadin Dayanismasi (Antakya Women's Solidarity Platform). There are also, communist women, people in the health sector, teachers. Arab Alawite women are the majority here, but there are also university students from all over Turkey (who study here and get involved)".

Women engaged in the feminist movement and the leftist movement are aware that a systemic change will not automatically result in gender equality. They are therefore continuing their struggle at the intersection of both movements. As Saime, a twenty-five-year-old member of the Kadin Emegi says, "Women's struggle is a long-term struggle, patriarchy is so deeply entrenched that the leftist movement alone won't save women". Such mindset is promising indeed and pushes women to continue their struggle. Their spirit was crushed only momentarily after the 1980 coup d'état, which is the main theme of the following section. 


\subsection{The 1980 Coup D'état and the Aftermath: Implications on the Arab Alawite Community}

The 1980 coup remains a source of fear and trauma among the Alawite community. Many of those who were involved in the leftist struggle leading up to the coup have shied away from political organizing altogether. Parents that are still haunted from the events surrounding the coup try their best to prevent their kids from political organizing. To say the least, the 1980 coup took its toll on the leftist community in Antakya.

The coup left severe damage to many families. Naciye was arrested when her son was six months old and served 2,5 years in prison. When she came out, she could not communicate with her son, because she did not speak Arabic and her son did not speak Turkish. Despite the hardships she and her family had to endure, she finds her actions to be right:

"I questioned what I had done and why I had done it and I found myself to be right. I was fighting for our rights. I was in the Democratic Teacher's movement. When the state should have been commemorating me, it tore my family apart, it deported me, imprisoned me, my kids suffered because of this. So, your belief in justice becomes damaged".

Burcu's family also took a hard hit. On the night of the coup, the police entered their home through the windows. She was sent to prison for 2,5 years, due to being a member of the Turkish Communist Party, because PWA was their branch. She recounts that night and the irreparable damage on her daughters Devrim and Tanya: 
"So the coup happened and I was taken in. Tanya was one year old. Tanya was with this grandmother one day and with the other grandmother another day, and as a result became schizophrenic. I should have sued Kenan Evren. I actually should have killed Kenan Evren [she starts to cry]. I was in prison for 2,5 years. Devrim became stronger, but Tanya shut down. She has the most dangerous kind of schizophrenia. Their father was also inside, he was a member of the Confederation of Progressive Trade Unions. We went in as husband and wife. He was in for 8-9 months. And everything came out; that I rented a bus for May 1st, that I sent clothing to prisoners... everything that I had done... We had asked the neighbors to give our kids to our relatives. Devrim was 4 and she had said, 'I'm not scared mommy, look I'm not crying, but I can't take care of my sister, I can't carry her'. And Tanya just shut down. Still to this day, whenever she sees a soldier, she hides behind me. For a long time they didn't bring her to see me. And then when she came she asked me why my face was checkered, because she saw me behind the fence. And after that she saw everything checkered. She had some sort of convulsions which damaged her brain. She almost died when she was 4 years old."

It is still difficult for Burcu to accept the repercussions of her detainment. Aside from the damage it caused to her daughters, being a female prisoner had its own connotations. Burcu explains how female prisoners were viewed as 'tainted':

"People were saying that the police and army had raped us while we were inside. Many people believed it. I even told my husband that if he believed I was raped, we could go our separate ways, that I could raise the two girls on my own. He had the nerve to ask me if anyone had done anything to me and that I should point them out. Even if it had happened, how can I know who it was? Our eyes were tied up in there. And it didn't happen, we really put up a good fight inside. They tortured us in many different ways. They threatened to capture our daughters. Throughout the first 90 days, you are tortured every day, you are sleepless, they threaten to kill you, rape you".

The PWA had dissolved, but they hired lawyers for Burcu and others that were arrested, which made them feel strong and supported. Burcu used her prison time to read feminist authors, such as Angela Davis, and about women's movements 
around the world, such as in Bulgaria and Nicaragua. She focuses on the positive sides of her life struggles:

"I read a lot of feminist works while inside, Angela Davis for example. There were so many women around us that inspired us. I couldn't inspire anyone yet, I was just a poor little bird from the village. Years later, a girl stopped me on the road, she was a university student and she told me, "Abla ${ }^{70}$, you inspired us". I was so surprised and asked how come. She said it was our resistance, determination, not being scared to name my daughter 'Devrim'71, that she will choose a husband like mine, who always had my back. Later I came in contact with the villagers, they told me that they were watching me from a distance. They said they had looked if I 'made it' and then they would send their girls to school, too. And today our village has the most educated girls in the whole country, aside from one other village in Kayseri, called Karaoz. We want to make a documentary out of this story".

Another extraordinary coup story belongs to Tahir. Tahir was sentenced to prison for 36 years, but ended up serving twelve years, during which he escaped through a tunnel he and his cell mates dug, only to be recaptured a week later. He had been a sympathizer of the leftist movement since 1975 and had joined the People's Liberation Party-Front in 1978, after the police raided the Dursunlu Cultural Association. The cultural efforts were insufficient to solve societal problems and the system did not allow it, therefore he had decided to become political. He says after the 1980 coup, hundreds of politically active people fled to Syria and Lebanon. He was caught in Mersin in December of 1979 during an operation. He stayed in solitary confinement for 3,5 years at an F-Type prison, which was a prison

\footnotetext{
${ }^{70}$ Abla means 'older sister' in Turkish and is used to as a sign of respect for women who are older than you.

${ }^{71}$ Devrim means 'revolution'.
} 
system specifically designed for political prisoners. They were separated because political prisoners began organizing other inmates. He and other inmates would stay in solitary confinement for months at a time, even though this was illegal. He painfully recounts his time in prison:

"We used to lay down by taking turns, it was so packed in there. The cell was below the ground and there wasn't enough oxygen. When I went to the court room, I got dizzy from the fresh air. We were tortured every day through falaka ${ }^{72}$. We were banned from seeing anyone, receiving letters, even with our families. We went on hunger strikes or performed other acts of resistance such as disobedience... most inmates were university graduates. In 1987, things eased a little... there were hunger strikes across the nation and increasing resistance. The breaking point was when a police officer admitted to torture, because he had a bad conscience and he ended up fleeing. This received nationwide attention, which eased things a bit for us".

The repercussions of the coup were not limited to prison cells. The coup brought some cultural restrictions, hitting minority groups the hardest. After the coup, Arabic was banned and one could get a prison sentence for up to five years for using the word 'Kurd'. Tahir tells me that Turkish courses were implemented and even 80-year-olds had to learn Turkish. All political organizations were banned, politically organized people taken in, tortured and sent to prison. This created a societal trauma and the new generation is being hindered from organizing. People automatically associate "örgütlenme" (organizing) with something negative and illegal. But Tahir believes organizing is crucial and necessary and shows the level of democratization.

${ }^{72} \mathrm{~A}$ method of torture which involves the beating of the soles of the feet with a stick. 
After a local concert I attended, where Kaldirim Music Group performed songs from a variety of minority groups in Turkey, Leyla was very emotional. She told me that in 1995, in the same auditorium where the concert took place, the police had raided a rehearsal of an Arabic theatre group and shut it down. She says, "We have come a long way to be able to see these days. We worked hard and took a lot of beating". She also remembers an Arab wedding she attended in 1994, which was raided by the police, who kicked the musical instruments and beat the musicians and anyone who tried to intervene.

Organizing the political sphere in the post-coup era continued to be challenging more than a decade later. Naciye explains:

"There was the $\mathrm{ABC}$ newsletter of the teachers and we had organized around that newsletter. I was one of the founders of the Egit-Sen teachers' union. Those were more oppressive times, I am talking about 1994-1995. We had founded our union in Nima's office. They were constantly shutting down unions. We used to bring tables, chairs, tea, glasses, etc. from our homes".

Naciye's feminist mindset allows her to reflect on the political space back then, and how she resisted the patriarchal mindset within the union:

"I had a male colleague, who was afraid of the newspapers and newsletters we were receiving and was burning them. I couldn't understand why he did this and got angry. He was taking away the right of others to read the material. Teachers need to read, they are the ones raising future generations. When I confronted him, he said, 'don't interfere in a man's job as a woman'. As if unionization is a man's job. So he viewed the union as a masculine space. I told him if I was working with him as a teacher under the same roof and was struggling with him shoulder to shoulder, I was capable of doing what he did, if not better, in unionization. He was always running against me during elections and I always won. His words had motivated me. Us women were on the streets more than men, we were much braver. We did a payroll-burning 
demonstration and when I got to the location and looked around, I didn't see any men, only women. I was surprised. After the burning was over, the men came out one by one of the shops where they were hiding. I told them, 'if we believe in the righteousness of our struggle, then we will not abandon the streets, we will always be here'. Because we are right, we are legitimate. I was so shocked. But this is how we opened up the streets. If we hadn't opened that space, it wouldn't have been this way. We were pioneers".

Although many have steered away from political organizing after the coup, people like Naciye, Tahir, and Burcu continue being involved in politics, whether it is through unionizing, women's organizations, or struggle for cultural rights. They find various political and social platforms to engage in, political parties being one of them, which I will get into in the next section.

\subsection{Political Party Affiliations: CHP, HDP and Kemalism}

So far, I have provided a gendered analysis of the leftist and socialist movements leading up to the 1980 coup and showed how women in Antakya have pushed against patriarchy within these political circles and how they have politicized in multiple domains. In this section, I will turn to political parties and explain how some of the long-standing party affiliations of Arab Alawites have recently stared to change. Alawites come from a long tradition of supporting the Republican People's Party (CHP), except for the short period of the Democrat Party ${ }^{73}$ during the 1950s. A Kemalist and social-democratic party founded in 1919, CHP is the first political party of Turkey. CHP is also considered Ataturk's party, who

\footnotetext{
${ }^{73}$ DP was founded in 1946, came to power in 1950, and was toppled with the coup in 1960.
} 
is revered by Alawites. The love for Ataturk is explained in terms of his secularist ideals, which were welcomed by religious minority groups such as Alawites, as they have been subjected to Sunni hegemony for so long. Ataturk is also a symbol of the end of the Ottoman era and the beginning of 'modern Turkey'. Considering Alawites were able to prosper only after the fall of the Ottoman Empire, it is understandable why Ataturk is so beloved. Even though DP was able to divert some votes from CHP, Alawites have primarily been CHP supporters since the beginning.

Can (2011) argues that the reason why Arab Alawites are pro-CHP and proAtaturk is not due to a 'religious' struggle or ethnic demands. This political identity is constructed based on "need". She quotes an interviewee from Antakya:

\begin{abstract}
"Being a CHP supporter and voting for CHP is only a preference based on the eradication of oppression. Even though we are being used, we say, 'at least they won't interfere in our affairs'. There is also this, a different movement cannot really develop, Kemalism will prevent this from happening. Our people, the Arabs, how leftist are they? They are pro-Ataturk, that's how leftist. At least the sharia system won't come and we will be able to practice our religion the way we want. But the people here have also started questioning CHP" (71).
\end{abstract}

Based on this perspective, we can infer that many Alawites have placed their hopes into the hands of CHP for lack of 'better' options, but this is starting to change. Considering how deeply entrenched Kemalism and CHP affinity are within the Alawite community, this change will not come easy. As an outsider, who has been living in Antakya for over 40 years, Naciye explains how intertwined Kemalism and CHP are with Alawite cultural codes: 
"There is an interesting fact here. The Arab Alawites here are very loyal to republican values and to Ataturk. They have internalized his success so much, that they practice namaz on October $29^{74}$. This is because Alawites were oppressed during the Ottoman era. They are more loyal to the republican values than all other ethnic/religious minorities in the region. Almost everyone has an Ataturk portrait or Turkish flag at home or even in ziyarets. I found this very peculiar in the beginning. But with time, they explained to me what they have achieved through Ataturk. There was the agha system before and the aghas were Sunni, while the workers were Alawite. With time, Alawites abolished the agha system and began owning land".

Several of my research allies were Alawite women in CHP management. Lawyer and head of CHP's Provincial Women's Branch, Dima believes CHP is the right path for her. When I ask "why CHP?", she says because it is her family tradition and CHP needs to be represented in the parliament. She is against abandoning CHP and contributing to the fractioning of the Left. She admits there needs to be substantive change in CHP's constitution, as “it's quire embarrassing in terms of women". Dima tells me how socialists do not view CHP as a leftist organization, which was echoed within socialist circles. Selda, who is pro-HDP, explains:

"My father used to watch the news at 6 pm everyday and he wouldn't talk to me during that time. He identified as a socialist, but he believed he had to stand with CHP, this is how people here are. He was politically organized during his youth, but then became pro-CHP. He used to tell us about his youth, he even wanted to become a candidate for mayor. Then he left politics for good (after the 1980 coup)".

Before HDP and SYKP, CHP was one of the few parties that gave women the opportunity to run for office. Pelin, the first and only female mayor of Hatay, ran for

${ }^{74}$ The Republic of Turkey was founded on October 29, 1923, marking the day as a national holiday, celebrated annually. 
office through CHP's platform. During her post as mayor, from 1999-2004, CHP could not reach the threshold to enter the parliament and she had to jump through endless financial hurdles. While Pelin's political leadership as a woman can be partially credited to CHP, many women are disappointed in the party. Halime, who owns her own landscaping business and is involved in environmental politics, started her political career with CHP, but was disappointed:

"1991, I scoped out the organizations here. In 1992 I joined the Environmental Protection Association. I was also in the CHP district office. I was responsible for organizing people, went to villages, spoke with our supporters. I was very disappointed in CHP at a very young age, it wasn't democratic at all. The candidates we chose (at the local level) weren't accepted, they were determined by the main office in Ankara. I was an idealist, but the team wasn't. Pelin was the president of the Environmental Protection Association and we enabled her to become the first female mayor. I was the Vice President, so I took over (the association) after she left. I am a founder of the Green Party in Turkey, so I quit CHP. I was very active the first two years, but when the Syria conflict started, they began echoing the German Green Party's sentiments on 'dictator Assad'. So I was out. Right now I am not a member of any party, but I am in politics, life is politics".

Berrin, who supports HDP, thinks of CHP as an elitist group of people, who are Turkish nationalists. She makes an important connection between modernism, CHP, and Kemalism, pointing out how it is all part of the greater assimilation project. She elaborates:

"We have many local councilwomen from CHP, who are elitist and are embarrassed by the poor people they are supposed to represent. Then you have the villagers who are the way they are and they also support CHP. They take Kemalism as modernism and they succumb to the assimilation tactics. So, they think they are becoming civilized, but then their own traditions become an embarrassment. This is assimilation. Until recently, people used to be embarrassed to say they are Arab, or that they look Arab. I think 
perhaps because they are being oppressed more, they are owning their identity more now".

HDP has paved the way for Turkey's minority groups to reclaim their identities and cultural 'otherness'. Labelled as a 'pro-Kurdish' party, HDP has embraced all ethnic and religious minorities in Turkey, as well as other marginalized groups, such as the LGBT community, women, and the working class. During a visit to the Samandag HDP Office in September 2015, a recent HDP-convert from the village of Tekebasi told me how he was often discriminated against outside of Hatay, either for being Alawite or Arab. He added, "HDP is the only party that brings everyone together under the same roof. I don't trust CHP, they are very profit-oriented and they don't have a different vision than AKP".

At the HDP Provincial Conference, seen in Figure 4.1, I had the opportunity to observe party politics at the local level. The council consisted of three women and two men. In line with the party's vision of instituting gender equality, the conference had adopted a "positive discrimination" strategy, where women spoke for eight minutes, while men spoke for six minutes. Participants were overwhelmingly Arab Alawites, but there were also Turkish Sunnis, Kurds, Alevis, Circassians, Armenians, and Arab Christians. Some of the speakers addressed the audience in their native tongue. A well-known socialist activist and HDP politician proudly pointed out how women's participation in HDP was very high. Several female speakers counteracted by arguing that even though women's participation was high, the party was still patriarchal. 


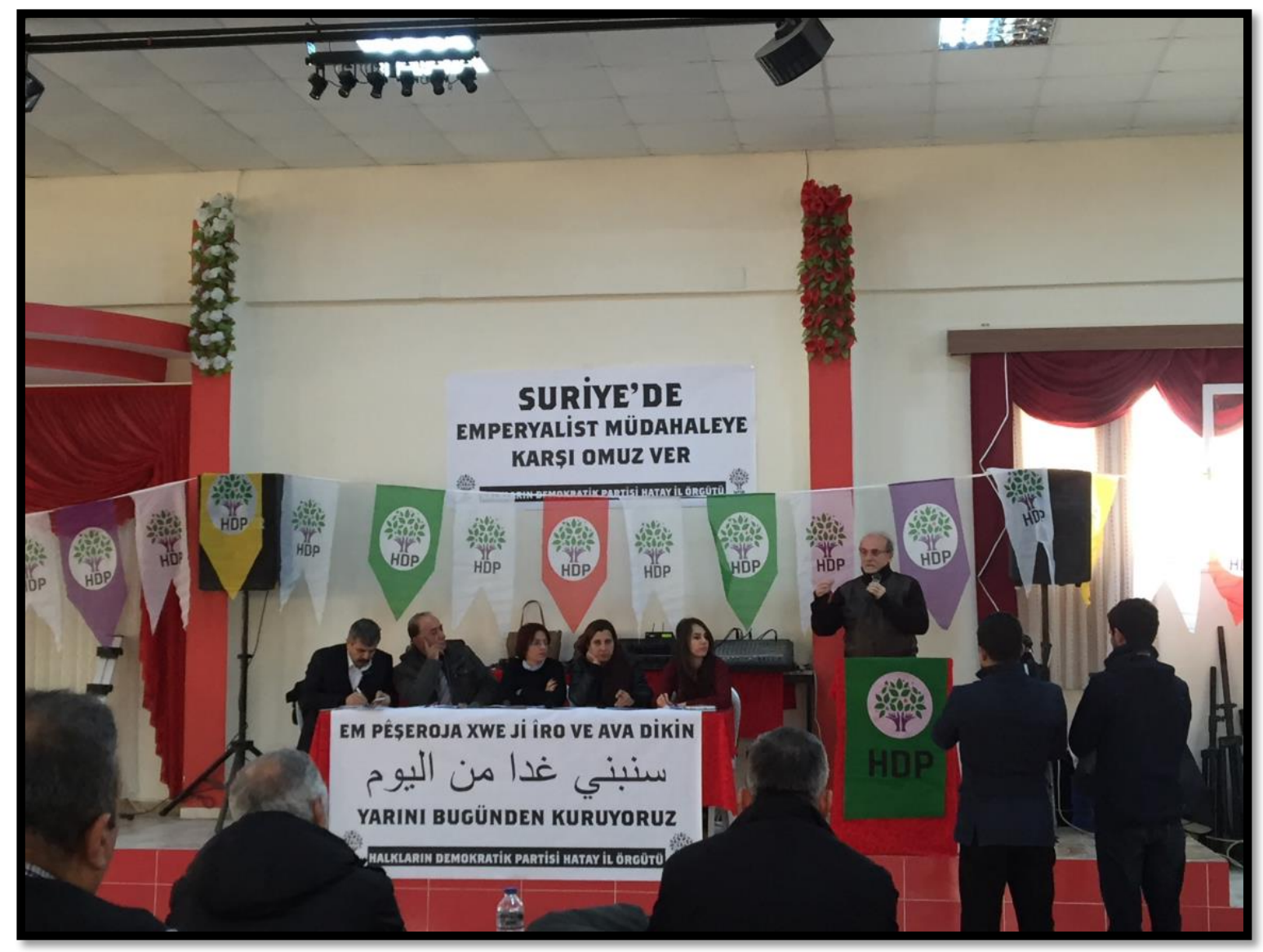

Figure 4.1. HDP Provincial Conference, March 3, 2016.

Some of the main concerns expressed at the conference was how decisions within the party have been top-down and calls were made for a more democratic process and bottom-up decision-making. As Arab Alawites, the community was concerned about HDP's Syrian policy. More clarity on the Syrian conflict and the refugee issue was demanded, and extra "sensitivity" on Alevism, including Arab Alawites, was requested. Lobbying to remove the mandatory religious classes and right to education in mother tongue was another recommended point of action. 
As of date, HDP politicians are being purged by the government, facing accusations of supporting Kurdish terrorism, and co-presidents Selahattin Demirtas and Figen Yuksekdag remain in prison. As Burcu told me in March of 2016, people are scared:

"It would be great if we could continue this struggle, but people are so scared, AKP really scared them. You don't feel the fear because you live abroad, but we feel it in our bones. And we couldn't even form a party".

Burcu concludes by criticizing HDP's reluctance to make room for Arab Alawite woman activists; "HDP doesn't put one of us in positions of power. They had a women's meeting in Deniz (Samandag), but they didn't invite Nima, Nuray or me". Clearly, Burcu is dissatisfied with the lack of inclusivity of local actors in the party. Making room for local Arab Alawites and woman activists within positions of power remains a challenge for HDP. In the meantime, Arab Alawites continue to navigate the repercussions of the Gezi protests and the ongoing Syrian Conflict, transforming these events into empowering experiences for their community.

\subsection{Arab Alawite Identity on the Rise: The Syrian Conflict and Occupy Gezi}

\section{Protests}

This section is broken into two sub-sections: The Syrian Conflict and the Occupy Gezi Protests. In the first part, I discuss the ideological implications of the Syrian Conflict on Antiochian Alawites, who for the most part stand with Syrian President Bashar al-Assad. I give examples of some encounters from the field that clash with Western perceptions of what is going on in Syria. I also point out an 
important and troubling outcome of this ideological clash, which is the growing divide between Sunni Turks and Arab Alawites, the latter labeled as "Assad-ist". There is lots of tension around this divide, coupled with the fear that comes from living on the Syrian border. I end the section with a discussion on an encouraging outcome of the Syrian Conflict, which is the "awakening" of the Arab Alawite identity, infused with feminist analyses of the "imagined nation" and "geographies of fear".

In the second part, I investigate what the Gezi protests looked like in Antakya and why it was such a 'big hit'. The Gezi Protest resulted in a big turn out on the streets in Antakya, especially in Alawite neighborhoods. I share excerpts from my conversations with Gezi protestors and why they felt the need to protest. I argue that the Gezi Protest reinvigorated Arab Alawite cultural and political organizing and gave a boost to women's and feminist movements. In this sense, Gezi can also be considered one of the contributing factors to the Arab Alawite awakening and Antiochian women's more recent politicization.

\section{The Syrian Conflict}

In March 2011, the ripple effects of the "Arab Spring" had reached Syria, and sowed the seeds of a conflict that is still ongoing. The conflict has been defined within various terms depending on whose perspective: civil war, civil unrest, proxy war, imperialist war, etc. Throughout this chapter, I will use the term "Syrian 
Conflict" to remain neutral and give weight to the opinions of Arab Alawites on the issue.

As a border region, Antakya is inevitably affected by the Syrian Conflict, not only because of physical proximity ${ }^{75}$, but also because of the heavy refugee (and paramilitary) traffic and the ethno-religious ties to Syria's Alawites, including President Bashar al-Assad (Assad). The conflict has become a humanitarian disaster, with millions of Syrians displaced, entire towns demolished, and thousands of lives lost. Aside from the humanitarian aspect of the conflict, there are also ideological implications. For one, while most of the Western world views President Assad as "the bad guy", generally speaking, he remains a figure celebrated ${ }^{76}$ among Antakya's Arab Alawites. While the West recycles the black-and-white narrative of "Dictator Assad is oppressing his people who were peacefully demonstrating for democratic change", the narratives told by Antakya's Alawites are more complex and multilayered, with plenty shades of gray.

75 During my fieldwork, we were able to hear exchange of fire and explosions across the border. We also witnessed the ordeal of the Russian aircraft being shot down by the Turkish Air Force.

${ }^{76}$ As you walk down to the waterfalls in the Harbiye district, you pass by vendors lined up on the side of the road, selling pictures of controversial figures: Bashar alAssad, Che Guevara, PKK leader Abdullah Ocalan, among others. 


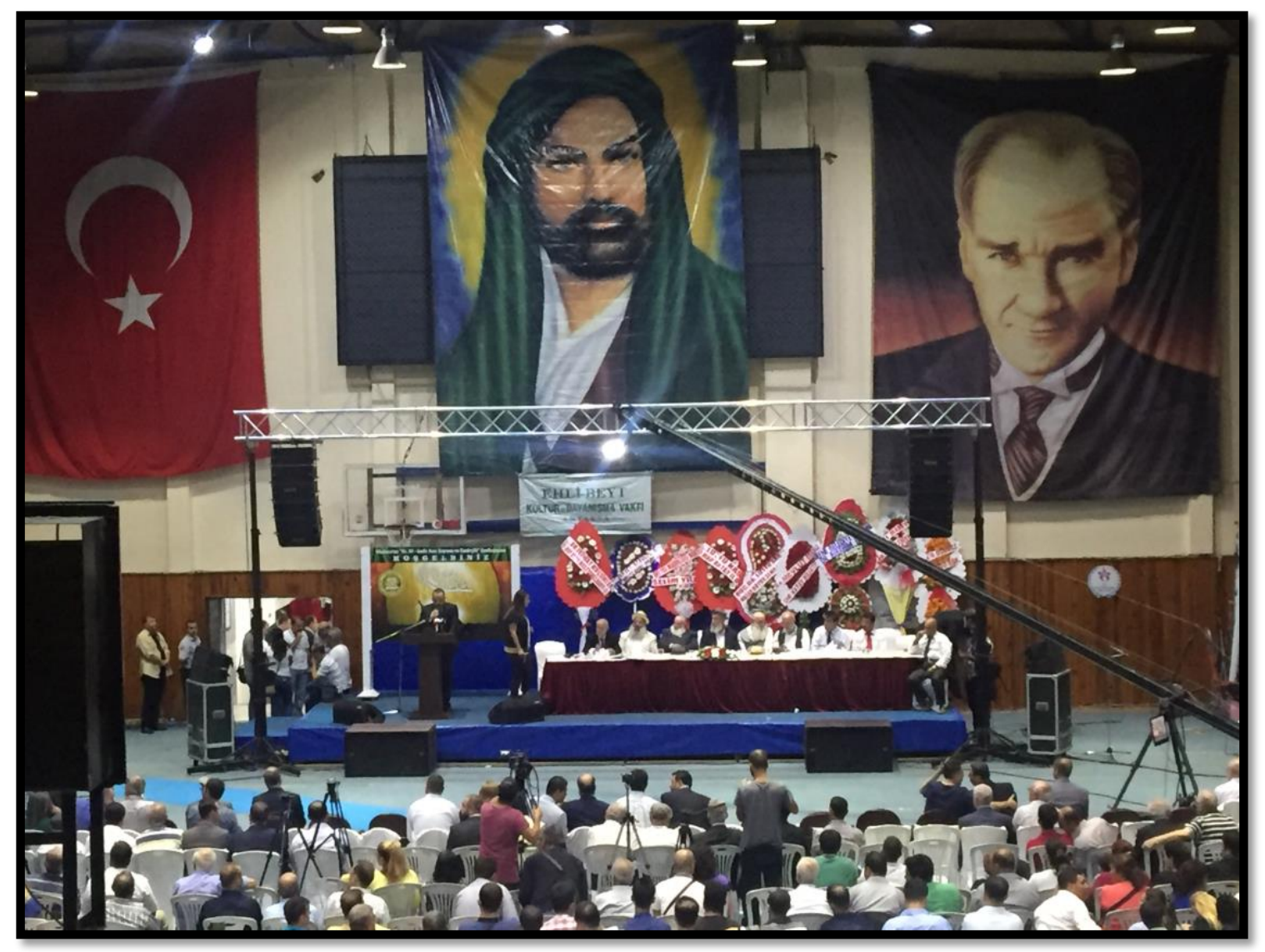

Figure 4.2. Ghadir Humm Panel in Antakya, organized by Sheikh Ali Yeral. The panel included several Arab Alawite sheikhs. The backdrop includes a Turkish flag, a picture of Caliph Ali and of Ataturk, November 5, 2015

The first alternative narrative I encountered was on my bus ride to Antakya in July 2014. The bus driver, who was an Arab Alawite from Samandag, told me during tea break: "There is no war in Syria. Assad is fighting for his people. External forces are creating havoc, including Turkey". Another compelling encounter was at the Ghadir Humm celebration and panel, seen in Figure 4.2, organized by the famous sheikh Ali Yeral; a young man was wearing a shirt that read "The Lion of Damascus Bashar Assad". When juxtaposing the dominant narrative circulated around Western media to such acts of support for a 'seeming' dictator, the outcome can be 
startling for an outsider. Actor and restauranteur Mert, from Harbiye, puts it this way:

"Elephants are fighting, ants are getting trampled on (in Syria). We aren't supporting Assad because he is Alawite, we are supporting the movement in Syria, because it is fighting against Western imperialism. Bashar is more democratic than his father. Which country is truly democratic (anyway)?"

Similar sentiments were expressed at the HDP Conference. One speaker warned that referring to Assad as a "dictator" is troublesome to many Arab Alawites. Former politician Halime, quit the Green Party because of this reason; "I am one of the founders of the Green Party in Turkey... I was very active the first two years, but when the Syria conflict started, they began echoing the German Green Party's sentiments on 'dictator Assad'. So, I was out”. During a visit to the HDP office in Samandag, another visitor told me, “They call Assad a dictator, but they don't say anything about the Saud or Qatar monarchs". This statement simultaneously acknowledges that the Assad regime is problematic, but he is being held to a double standard by the West. During a panel at the Kadin Emegi Summer Camp, titled "We need Feminism for Peace", one speaker commented:

"The real reason for war is economic gains. The reason for the Syrian Conflict is not the fact that Assad is oppressing his people. All other reasons are men's creation, wars are men's work, as men own $99 \%$ of the wealth".

The feminist interpretation of war as a tactic for economic gain (and a masculinist project created by and for men) holds truth for the greater Alawite community, who see the Syrian Conflict as a war perpetuated by the West in order 
to control Syria for geopolitical reasons. This perception especially holds truth in socialist circles and is repeated in almost all domains of life; the home, the community, and political platforms on the national level. In studying conflict and international relations, Enloe argues that " $[\mathrm{t}]$ here needs to be a feminist consciousness informing our work on gender", meaning 'gender' is not enough and we need a "feminist consciousness [that] keeps one taking seriously - staying intellectually curious about - the experiences, actions and ideas of women and girls" (2004: 97). This is precisely why it is important to amplify the voices of Alawite women on the Syrian Conflict, especially because such geopolitical issues are typically masculinized and women are left out of these conversations. Hence, it is promising that Alawite women are organizing multifaceted panels and discussions on the ongoing war in Syria. In Chapter 6, I discuss in detail how Alawite women are mobilizing around topics of violence, war, fear, and displacement, and how they use a critical transnational feminist approach that is based on the desire of solidarity among women of the Middle East.

The Syrian Conflict has also contributed to the othering of Antakya's Alawites as "Assad-ist". During a focus group in Harbiye, one woman expressed her concern about this Alawite/Sunni division:

"People already don't know much about Alawites... they are trying to present us as Assadist, enemy, opposition, anti-Sunni... by using this as a political tool, they are also creating a sociologic division. They are trying to paint a non-existent picture. They are trying, but inshallah (God-willing) they will 
not succeed. The Reyhanli bombing77 is the best example. Yes, they said, ' 3 Sunni citizens have died'. For us, they were humans, not Sunni. But they were trying to blame the people of Harbiye, that they made the bombs to kill Sunnis. They tried to create chaos. But they did not succeed and will never succeed, because this kind of perception has never existed here".

Besime tells me that conversations would get heated between faculty and students on Syrian politics, while she was studying at the Bolu University in the Black Sea region, northern Turkey. These disagreements were mainly between AKP supporters and the rest. The tension became so high between her and nationalist students that she had to leave the classroom on one occasion.

Besime is from Tekebasi village in Samandag, which is one of the villages closest to the Syrian border along the coastline. She was in Bolu when the Reyhanli bombing happened. She tells me that after the bombing, Antiochians in Bolu slept with a prepacked bag, so they could quickly go to their families in case something happened back home. Her family thought about sending the rest of the kids to Bolu or Izmir for safety reasons. She argues that with Russia's involvement in Syria, Arab Alawites started feeling safer; “We believed that Assad wouldn't give up on us, but we still believe that sooner or later we will be forced out of here". Social psychologist Berrin explains how Alawite massacres in Syria are affecting Alawites in Turkey:

77 In May 2013, twin car bombs exploded in Hatay's Reyhanli district, killing 52 people. Reyahli is a primarily Sunni district, housing thousands of Syrian refugees. The suspects for the bombing include local Alawites, the Syrian government, in addition to groups such as ISIS and al-Nusra. 
"Look at Syria, it's a representative Alawite state, and everyone is attacking him. Of course, we all know that the actual problem isn't the identity, but when that is underlined, people tend to stick to their own identities even more. As long as there are attacks and we are oppressed, we hold tight to our identity".

The "Arab Alawite awakening" in Turkey can be considered an 'unintended consequence' of the Syrian Conflict. Gulsen has been teaching Arabic for seven years and after the Syrian Conflict her lessons doubled. While the older generation discouraged their children from learning Arabic, nowadays they are encouraging it. She says, "We woke up because of these attacks. We have a cultural connection to Assad, that's why it's as if we are being attacked. How can the beheading of a Syrian Arab Alawite by the Islamic State of Iraq and Syria (ISIS) not affect us? It makes me want to be more Alawite".

Tahir claims that the Arab Alawite identity has politicized after the Syrian Conflict, especially due to the cultural, familial, and economic ties. As Ozge, member of SYKP, put it, "people were more politically active before the 1980 coup, then things died down, but picked up again after the Syrian Conflict and Gezi protests". Yeliz, a lawyer, agrees that the Arab Alawite identity is "on the rise". She says, "Before these incidents, this region was very quiet and peaceful, there was no sectarian conflict". She confirms that Arab Alawites are sympathetic towards Assad and Syria, which creates problems with the Sunni community. Kerim, a mathematics teacher from Samandag, explains how with the war in Syria, Alevis in general and 
particularly Arab Alawites have been targeted by the Wahhabi-Salafist ${ }^{78}$ ideology and their physical erasure has become a concern. He also says this has caused Arab Alawites to embrace their ethno-religious identity more, language being one of the main points of action. For example, before the Syrian War, Kerim tells me there were no Arabic signs at protests, but now there are. More Arabic language courses have opened. People are increasingly eager to assert that they are Arab Alawite. There is a big movement for the preservation and appreciation of the "mother tongue" as well as Arab Alawite songs, plays, customs, rituals, folk tales, etc.

When I ask Selda why there is increased politicization of Arab Alawite identity in the past 5 years, she responds:

"We feel Syrian more than we feel Turkish, that's why. There is war in our home right now. I think that's why. And the current system is trying to transform this war into a sectarian war. We know very well that this is not the case, but we have to be aware of it, because at the same time there is a war waged against Alawites. Maybe I am reducing it to something very simple by saying this, but for me ISIS means the war of Sunnism. I think that's why there is a rise in the Arab Alawite identity at the moment, we are trying to own our identity more".

Belgin, SYKP member from Samandag, has a similar perspective:

"After the Syrian Conflict, we have been trying to go back to our roots. At a certain time in my life, I was also prone to assimilate. But now people are more adamant on speaking Arabic. I like the fact that we can talk about this stuff at home now... We have been discriminated against by the state and this makes us want to learn more, discuss more, raise our voice, edu cate ourselves. Even if our chances are meek, we still try to do what we can".

\footnotetext{
${ }^{78}$ Ultraconservative and fundamentalist branch of Islam stemming from Saudi Arabia.
} 
Despite the "awakening", the Alawite community remains extremely worried. Dr. Matkap, President of the Research Institute for the Middle Eastern Arab Peoples, points out that the institute is a direct outcome of the Alawite awakening and politicization. However, the idea that "if something happens to us here, there is always Syria" is gone, according to him. "If the (Syrian) regime falls, we are next," he says. He concludes that while it is possible to empathize with the social and psychological worries of the Arab Alawite community, the local government does not recognize these worries or tries to reassure them of their safety.

HDP politician and feminist activist Neriman finds the recent attempts to organize invigorating:

“In Hatay, Arab Alawites haven't organized up until 4-5 years ago. They are slowly starting to organize. It is related to the Syrian Conflict. The Dursunlu people's council is an example to this. Tahir is the head of this council. In certain neighborhoods in Samandag, there are councils. In Cekmece there are people who come together and share their problems, even though there is no official council. In Serinyol we have a council, almost. If we can spread this to all Arab Alawite neighborhoods, I think we would be very successful. There is actually a society here that would be able to put a halt to the transportation of arms to the Middle East, if they were organized. But since we are not organized, there are jihadists and arms going back and forth under our noses. I think the situation in the Middle East will be at the core of an organization here. This is why people here want to organize, for self-defense, more than self- governance".

Local vocalist and feminist activist Nurgul sees the awakening as a positive start, but not enough. She underlines that persistence is key for effective organization:

"After the Syrian Conflict, there is an awakening. You know, we still have relatives there. Many of us migrated here from there. There has been an increased search for our identity. But this is very limited, I can't say it goes a 
lot further than courses, talks and panels. But I think the mindset that the kids shouldn't speak Arabic so that they speak Turkish more properly, has been broken. The Gezi protests also had an effect, but the actual factor was Syria. The oppression against Arab Alawites there, made people go back to their roots. Like I said, right now it's still very individualistic. I cannot say it's very organized. There are new institutions, associations, courses, magazines, etc. These are very important, but they need continue and transform into a movement, organization. After a few issues, magazines discontinue. After a few events, associations are not heard of anymore. In this sense, organization is crucial. The reason for a gap here is the fact that it is a disorganized community".

Extending Anderson's concept of "imagined communities" (1983), feminist political geographers (particularly scholars on feminist geopolitics) have complicated the "imagined nation". Such scholars have shown how national identities are produced, imagined, and maintained through heavily gendered, sexualized, and classed ways (Secor 2004; 2007; Faria, 2013; 2014). We see a similar phenomenon with the Arab Alawite community in Turkey and their 'imagined' relationship to Syrian Alawites. Like Mohanty, when I say "imagined”, I don't mean "not real", but rather "potential alliances and collaborations across divisive boundaries" (2003: 46). At the intersection of emotional geographies and feminist geopolitics, we find intimate, everyday acts that reinforce the imagined community and reestablish ties, especially in the Diaspora (Faria, 2014). Antiochian Alawites, too, nurture and maintain such ties through reiterations of Arab and Alawite identities, starting from the home (which I will get into more detail in Chapters 5 and 6). 
Furthermore, through feminist work on "geographies of fear" or "embodied geopolitics" (Valentine, 1989; Pain, 2009; Fluri, 2009; Clark, 2013; Datta, 2016), we can conceptualize the fear of living on the border, across from which ISIS is killing Arab Alawites (amongst other ethnic and religious groups). Aside from this factor, there are also certain bodies (such as Syrian women in burqas and bearded men) that instigate fear in Arab Alawites in Antakya, as they become symbols of women's oppression, violence against Alawites, and Sunni hegemony. And the fact that neither the Turkish state nor its local representatives are taking steps to understand or curb this fear is exasperating the existing lack of trust Alawites have towards the state. This, in turn, is reinforcing the "imagined Arab Alawite community" and adding fuel to the Arab Alawite awakening.

\section{The Gezi Protests}

"There is so much to talk about, sometimes I wonder what good it brings to talk." -Ekin, Ali Ismail's mother

In the same fashion, Occupy Gezi ${ }^{79}$ protests, or Gezi Park protests, during the summer months in 2013, also contributed to the "Arab Alawite awakening". Sheikh Celal tells me how the Gezi protests played big role in the awakening by drawing attention to the fact that those who died during the protests were Arab Alawites

${ }^{79}$ Gezi Park is a small green are in Istanbul's Taksim Square. On May 28, 2013, protests erupted contesting the urban development plan that would demolish the park. The growing protests, drawing thousands of civilians all over the country, were met by violent police forces and eventually dwindled down towards the end of August, 2013. 
from Antakya. Known as the "Gezi martyrs", Abdullah Comert, Ahmet Atakan, and

Ali Ismail Korkmaz died as a result of the violence at the protests. After Istanbul and Ankara, Antakya was the platform of the most intense Gezi protests. Since those who protested were mainly driven by their frustration with the AKP government (including ethnic and religious minority groups, women, members of the LGBT community, leftists, socialists, secularists, environmentalists, etc.), the majority of those against the protests were pro-AKP, Sunni populations. Therefore, in multicultural places like Antakya, this created tension between communities.

Why was Gezi so intense in Antakya? Besime thinks it is due to the 'hyperpolitical' nature of the region. She explains:

\begin{abstract}
"Here people are political without being aware of it. This is because we are one step ahead everyone else, in terms of political consciousness, intelligentsia, as Antakya, but mainly as Arab Alawites. This is due to being able to stay humane, no matter what troubles we've faced in the past. And now, our youth is trying to raise their knowledge and consciousness. The rise in identity began with Recep Tayyip calling us 'Nusayri' in the end of 2010s and early 2011s. This region has always been othered... The Gezi period awakened Arab Alawites more than others. The Syrian conflict also was an instigation".
\end{abstract}

Nurgul believes that Gezi was fuel on the fire, which had begun with the Syrian Conflict:

"I think the biggest reason for the overwhelming support for Gezi is the Syrian Conflict. Even a year before (the Gezi protests), there was a movement here, because people didn't feel safe anymore. People were seeing men withdrawing money from the bank with Kalashnikovs. They started seeing El Qaeda militants. And there is also the economic aspect, there were people who made a living out of this. The tourism industry also was affected, restaurants, cafes... thousands of people making a living out of this sector. 
But now people are scared to come here. Tourists from Lebanon or other Arab countries don't come anymore. So, there was already a commotion here. There were already clashes with the police 8-9 months before Gezi. But Gezi made it more organized and took it to the next level. The fact that it was taking place in other parts of Turkey, created more solidarity gave more power. Also, the deaths also had an effect. Abdullah Comert, Ahmet Atakan and Ali Ismail Korkmaz, since they were from here and were Arab Alawite, people protested their killings".

Yeliz, one of the many lawyers working on the Gezi Martyrs' Case, was not surprised by the overwhelming support Gezi received in Antakya. She blames it on the "responsive" nature of Arab Alawites. She told me she was proud of the "kids" that were arrested during Gezi. “They said that the 90's generation is very apolitical, well they proved everyone wrong," she added.

Antakya's Arab Alawite neighborhood of Armutlu received the widest media attention in the area because of the intense clashes with the police and the deaths of Abdullah Comert and Ahmet Atakan. Akif and his mother, who live in Armutlu, tell me that during the Gezi period, the neighborhood was paralyzed. People would go to work during the day and come home early to join the ongoing protests. In the morning people picked up trash off the streets and everyone cleaned up the front of their homes, because many municipal services, such as garbage pickup, were suspended.

Half of the Gezi protestors were women, which is remarkable, considering the historically predominant male presence on the streets and in public spaces. According to Naciye, one of the main reasons for the high turnout in women is their 
concern for the AKP government taking away their rights. "Women don't want to be shoved back into the house," she says and expands:

“Republican values have given women equal rights. They didn't have to fight for these rights, but now that they are being impinged on, so they begin to fight back. The AKP's women politics angered the women here, so they took to the streets. They were right".

Nilay, for example, stayed in a tent for ten days during Gezi, as part of Kadin Emegi. She says many women who came to the protest were wives, mothers, etc. and they voiced their frustrations about migrant labor and other systematic problems such as appointments of public officers. Cennet adds:

"During the Gezi protests, yes, women were on the streets, but they were on the streets because of the ban on abortion, increase in violence, confinement into the homes. They were on the streets because of their own demands and they showed their true colors. I think the women's efforts in Samandag are very important and valuable and women's solidarity here is exemplary for other provinces".

Gezi was also a turning point for many Arab Alawites, who were not politically active before. Mother of two and member of SYKP and Kadin Emegi, Nur had no political affiliation or aspirations prior to Gezi, but was inclined to take the streets and raise her voice:

“During the Gezi protests, I didn't have anything to do with an organization, Kadin Emegi or SYKP. I used to be on the streets with the kids, screaming on the top of our lungs, not scared of anything. Sometimes we were outside all night. My husband went through a lot during the 1980 coup, so he didn't participate. My family didn't want us to join in the protests. I used to say, 'if you don't raise your voice, if I don't raise my voice, then who will? Who will fight for our rights?' Of course, it would have been better if those kids hadn't 
died. When I remember seeing Ahmet Atakan's body... it saddens me a lot. I wish the door to the rooftop was locked so that he couldn't have fallen off".

Nazan, who served as the head of CHP's Defne District Women's Council after Gezi, was, in her own words, "just a housewife". She eagerly explains the process of her political transformation:

“Gezi was a turning point for all of us, we realized we couldn't stay quiet. We realized that something had to change, that we had to place our hands under the rock. During that period, we had different friends. I switched from passive politics to active politics after Gezi. I used to participate in events, but I didn't take on much responsibility. But after Gezi, my life changed a lot... My friends and conversations changed. We got courage to transfer our ideas into action. We wanted to raise awareness. We used to go to all events organized by community centers, CHP, HDP, SYKP, TKP and we began to have a voice there, my friends and I. We began to support each other. During the local elections right after Gezi, a candidate offered me to work with him, then he asked me to become his consultant".

There are a many stories such as Nazan and Nur's, in which Gezi was an catalyst for their politicization in a more positive manner. There are, however, those who did not necessarily 'choose' to politicize, but were pushed to do so, such as the families of the Gezi martyrs.

Ali Ismail's older brother Izzet, who is a lawyer in Antakya, and their mother Ekin are some of the people who practically "fell" into the lap of politics. "Before Ali Ismail, our family was apolitical... With Gezi, we fell right into the lap of current politics... Now we got used to panels and interviews (all across the country)," he says. Ekin adds: 
"I travel out of town sometimes, they invite me to events, to memorials. Our lives have changed completely. Our life from 3 years ago is very different than today. Our lives changed. May God damn those who have caused this, what can I say".

After Ali Ismail's death ${ }^{80}$, the family wanted to continue his way of life and started a foundation in his name. "We didn't just want parks and roads named after him, we wanted to focus on what he was doing when he was alive," Izzet tells me. He continues:

"We were politicized (after Gezi), began reading things politically, including talks at home, TV programs... everything changed. The 90's generation politicized and began affecting others. We used to be Turkish nationalists, but after Gezi we began questioning the Kurdish struggle. Because during Gezi, we were also regarded terrorists by the state".

Izzet explains how Arab Alawites were chin-deep in Turkish assimilation when Gezi protests hit:

"We had just embraced the Turkish identity and idolized Ataturk. We accepted the system and didn't question it. But Syria and then Gezi started a process of politicization. The Syrian war is one of the main factors why Gezi was so strong here. I know that people unrooted trees in Armutlu, so the issue wasn't really trees. LGBT went to protest their issues. Gezi was the last drop. The Syrian conflict was the beginning".

He concludes by saying that Gezi brought to light the system's error and "this started bothering us". That is when Arab Alawites began to rise.

80 Ali Ismail was a 19-year-old university student in Eskisehir, central Turkey, during the Gezi protests. He was beaten to death by government supporters and undercover policemen, slipped into a coma, and eventually died. His trial is still ongoing. 
One year after Gezi, I attended a memorial for the Gezi Martyrs on July 10, 2014 in Antakya. Swarms of people huddled into the arena, chanting slogans, throwing their fists in the air. The memorial included concerts, poem recitals, and talks by the parents of martyrs. There was one message that was continuously reiterated: "halklarin kardesligi", which means "sodality of the peoples". In this sense, spaces and events that commemorate the Gezi Martyrs are not being used to instigate hatred, but to spread peace and tolerance.

In her paper Biopolitics and the Gezi Protests, Erhart (2013) highlights women's involvement in the Gezi protests. She claims that while "Gezi protests did not put an end to institutionalized sexism in Turkey nor did it completely transform a sexist and homophobic culture... it definitely was the largest civil disobedience we have witnessed in our lifetimes" (2013: 302). She further states, "Women from all walks of life raised their voices against the roles the government has assigned to them and rejected the state's involvement with the bodies" (2013: 302). In Antakya, Gezi protests echoed such concerns of women, coupled with opposition to Turkey's involvement in Syria and the Sunnification of social and political spheres.

Fairhurst, Ramutsindela, and Bob critique how studies on women in social movements since the mid-1980s have been "descriptive and focused primarily on women's involvement in organizations linked to survival strategies such as informal trading clubs, soup kitchens, and sewing clubs" (in Staeheli, Kofman and Peake, 2004: 205). Feminist theorists have challenged this hegemonic approach, which in the end reinforced traditional gender roles. In the Gezi discourse, we see women 
assuming leadership roles, becoming icons of resistance, and breaking gender stereotypes that box women into certain understandings of womenhood and femininity.

In short, the political trajectories in Turkey since the founding of the state have molded the experiences of Arab Alawites in distinctive ways. While the rise of leftist and socialist movements in the 1960s and 70s have encouraged Alawites to become more visible in the public spheres through political articulations, the more recent events in the region (Syrian Conflict and Gezi protests) have caused a shift in their cultural expressions. Women have been part of this process all along, but have not been readily recognized. Through this chapter, I aimed to show that Alawite women were on the streets and in the kitchen, in the frontlines of protests and at their work place, in prison and on the playground, assuming multiple roles in their struggle for a more just and equal society. In the coming chapters, we will see the many ways Alawite women have (and continue to) transform social and political landscapes, both in theory and practice. 


\section{CHAPTER 5: "We are always one step ahead": The Identity Construction of Arab Alawite Women}

"I think when compared to the rest of the country, there is relative gender equality among the Arab Alawite community. Of course, total equality is not reached, but when compared to the rest, I think this place is where women would feel free the most. I've seen other parts of Turkey. Women here also have problems such as income and education, but compared to the rest, we are ahead." - Amina from Harbiye

On a night out in Antakya, in spaces of entertainment and socializing, usually a bar or café, you will see that women make up about half of the crowd, either in allfemale groups or mixed groups, which is quite unusual for a city in this part81 of Turkey. Once you are familiarized with the complex and multi-layered cultural codes of Antakya, you will recognize that most of these women are Arab Alawite. The specifications of the time and space play an important role in decoding any given social setting. For example, what is the name of the owner and/or business? Does the locale serve alcohol and who does/does not consume alcohol? Is it acceptable for men and women to mix in this setting? What kind of music is played (Arabic or Leftist singers/groups)? What time of the year is it- any religious days? Being able to answer such questions will help determine the cultural makeup of the social setting and thus, come to realize that the majority of these "unaccompanied" women in the social sphere are Arab Alawite.

${ }^{81}$ By 'this part' of Turkey, I mean non-Western Turkey. The Western coast of Turkey is regarded as the more modern, open-minded, and liberal part of Turkey, while the Eastern, Southeastern and Black Sea regions are considered more religious, traditional, conservative, and repressive. 
When I first began fieldwork, I was very driven by the following question: are Arab Alawite women more liberated/empowered than women of other ethnic/religious backgrounds in the region? If so, what are the reasons? While I quickly realized that the question itself was not very productive, the answers did all the work in terms of understanding gender dynamics within the Arab Alawite community and in Antakya. One of my favorite explanations, because it conveys a well-informed and clear message, belongs to feminist activist Leyla:

"Women's status is very powerful in the social domain. Very powerful. When compared to other parts of Turkey, the lifestyle here is more geared to the West. It is a more modern lifestyle. And as you probably have observed, in any setting you enter, entertainment venues, shopping areas, streets, you will see overwhelmingly women. This is especially true for Arab Alawite areas."

In this chapter, I will present some of the most common answers I received. Starting with clothing and other "embodied performances of identity" (Gokariksel and Secor, 2010: 145), I will explain how Alawite women construct themselves as modern, empowered, and progressive citizens. I will also analyze ethnosexual frontiers and crossings, using Joane Nagel's concepts of ethnicity, sexuality and collective imaginings. As part of the discourse on 'dressing the body' and 'the promiscuous Other', I will discuss the construction of Arab Alawite women as religiously and sexually deviant in the Sunni imagination. In the following section, I will discuss my findings on the reiterations of Alawite women as secular and democratic subjects and their appreciation for the leftist and socialist movements, which embraced women. Moving on to socio-economic factors, I will discuss how 
women's role in the household economy and the boom in girls' education have been key aspects in their economic empowerment. As I mentioned in the earlier chapter, Alawites have a long history as peasants, which was conducive for women to work alongside men in agricultural activities. Since male labor migration is an epidemic in the community, I will dedicate the last section to transnational male migration and its effects on Alawite women who stay behind, in charge of the household.

This chapter is important in understanding how the unique belief system of Alawism, the socio-economic conditions which have pulled women to the forefront, and the Arab Alawite experience with Turkish nationalism and modernity have been contributing factors to Arab Alawite women's (self)-image as secular, educated, socially independent, economically empowered and sexually promiscuous. It is crucial to recognize these 'imaginings' and the contributing factors, because Alawite women both define themselves through these constructions and/or are also marked as such. Understanding this will help us better follow Alawite women's experience and the actions they take while navigating through the 'public' and the 'private'. This chapter will also serve as a more 'descriptive' precursor for Chapter 6, where I get into women's political and feminist activism.

\subsection{Embodied Performances of Identity: Dressing the Body and Ethnosexual Imaginings}

"We were expecting a stern, professor-looking, covered woman, but then you arrived with ripped jeans and a crop top, and we said, 'she is one of us!'”Participant of an all-female focus group 


\section{The Politics of Tesettür}

The above quote relays the sentiments of the focus group participants had pertaining me, as an outsider of Antakya. Not knowing my regional, ethnic or religious roots, they assumed that I was a 'conventional' Sunni woman, who came to their village to talk about women's issues. They found my style of clothing 'relatable' and deciphered me as someone who shared their cultural values. The inscription of my body as "one of them" illustrates how much value they place on "embodied performances of identity", a term I borrow from Gokariksel and Secor's (2010) study on Sunni women's tesettür ${ }^{82}$ fashion in Turkey.

In the article, the authors argue that, "when it comes to covered dress in Turkey, what is acceptable, for whom, and under what circumstances is a contingent and shifting determination" (2010: 120). The authors used the term to describe the representation and consumption of Islamic fashion and how "age, personal preference, and style" plays an important role "when making choices about dress" (2010: 120). Some tesettür styles may "call for too much attention" and considered “inappropriate". Even so, tesettür is highly associated with piety, modesty, and virginity in Turkish society. I borrow the concept of "embodied performance of identity" to explain how 'not wearing the tesettür' also has complex meanings and ramifications, especially if there are cultural signifiers involved. Unlike Sunnism, in Arab Alawism women are not required to practice tesettür, which emboldens

82 It is used in Turkish to signify a set of Islamic practices wherein women cover their heads and bodies and avoid contact with unrelated men (Gokariksel and Secor, 2010: 118). 
Alawite women to construct themselves as 'modern', 'secular', and 'democratic'. This construction creates a binary between Alawite women and Sunni women. Even Alawite men interpret this embodied performance as a symbol of women's liberation. Newly-wed Ahmet from Samandag gestures towards the window of the café where we were sitting and conversing over tea, and proudly says:

"Look outside, all women who are uncovered are Alawite girls. Of course, clothing doesn't mean everything, but Alawite women have more freedom... The rest of the world is going to the moon, we (as a country) are still arguing over headscarves".

Gokariksel and Secor's study challenges the common perception that the headscarf is anti-modern, by showing how tesettür fashion is becoming more encompassing and has made its way into the discourse on modernity. The authors claim that there is an "ongoing struggle over the (re)definition of fashion, femininity, class, and tesettür" (2010: 125). According to Gokariksel and Secor, rural to urban migration in the 1960s and 70s resulted in the association of the headscarf with "the lower-class status and rural origins of migrants" (2010: 121). However;

“Today's tesettür producers market colorful, diverse, and constantly changing styles... With hotel weddings, beach vacations, and country club sports becoming desirable elements of a high-class Islamic lifestyle (Bilici 1999), tesettür-producers manufacture and market covered swimwear, bridal gowns, sportswear, suits, and maternity clothes. The styles, colors, and cuts of this apparel vary greatly, from bold and close-fitting to more conservative looks. Whether and to what extent these styles and their marketing are 'Islamic' is a topic of ongoing debate" (Gokariksel and Secor, 2010: 122). 
While Gokariksel and Secor are complicating the age-old orientalist narrative that clothing are markers of (a certain kind of) progress, in many ways the headscarf continues to be regarded as a symbol of 'backwardness' not only in the Global West, but also on the home-front. Arab Alawite women, for the most part, perceive tesettür as oppressive and backward. This perception has strong connections to the colonialist view of "covered women as oppressed" and the Kemalist agenda of Westernizing Turkey through a series of abrupt bans and changes, such as the headscarf ban in public institutions (Yilmaz, 2013). Thus, tesettür politics are indicative of a much bigger issue in Turkish society; the anxiety between Islam and the "West", the rise of political Islam, the tension between AKP/AKP-supporters and Kemalists, and the Sunnification of social and political spheres. The intensity of such tensions, both from the past and the more recent, may result in feelings of disgust, pity, and even fear. For example, during one of my house visits, my host Behra's cousin narrated in an aggravated tone how she encountered a Syrian woman in a burqa on the bus, whom she asked, "Why are you covering your face? Who would look at you here?" The startled woman replied, "what can I do, my husband wants me to cover". The cousin's daughter, who is a medical student, joined in the conversation by saying, "Perhaps I am influenced by the political events, but when I see Syrians at the hospital, I feel disgusted". Both statements demonstrate how Arab Alawites view the covered body: symbols of repression and backwardness that instigate fear and disgust. Nevertheless, this fear of repression is not new nor 
baseless and is strongly connected to the AKP politics in the country, which I will discuss in more detail in the next chapter.

Clothing remains a crucial symbol of freedom for Alawite women and they often compare themselves to Sunni women. Let's look at what Harbiye silk factory owner Amina says about modesty and clothing, while drawing a comparison between Alawites and Sunnis:

“Even though Arab Alawites aren't as conservative when it comes to clothing and headscarf, our religious leaders might say things like that (to dress more modestly). If my head is covered but I am talking badly about others and tell lies, what is the significance of that? But of course, it is not like the Sunnis with us. Even when we cover our head, our hair shows. Our religious leaders might put some pressure on that, but not the society, on the contrary they are maybe too open".

Amina clearly distinguishes between the expectations of religious leaders versus the Alawite community, the former being more conservative than the latter. She depicts Alawite society as an open (even "too open") society, where women are allowed to choose how to dress their body. At the same time, she remarks how modest clothing can never be the sole indication of a person's piety, by the same token suggesting that 'less modest' clothing cannot be the sole indicator of a person's liberty. Regardless, Amina believes that Alawite women have always enjoyed a more relaxed and free environment compared to others:

"Even though there is a generation gap, I think Arab Alawite women were always ahead in comparison to other societies. My grandmother used to hire a personal driver and rent a house by the thermal springs due to her illness. At that time, I cannot think of any other society doing something like that. 
Alawite women were always more progressive in their time, always one, even two steps ahead".

Many Alawite women recognize that freedom in clothing does not translate into women's liberation. Sevil, vice principal at a high school in Samandag, explains how the 'clothing issue' paints a pretty picture that is not so true:

"Women in other regions might consider women here very free, because they themselves are oppressed. Arab Alawite women can wear what they want. Women in Kırıkhan ${ }^{83}$ have to cover up, so they think Alawite women are ahead because of our freedom in clothing. But women here also have little say and lots of responsibility. They are married young ${ }^{84}$, their husbands work overseas, they have to be both mother and father, they have to take care of the kids and the husband when he is visiting. But the decision-making is in the hands of the in-laws. They might seem freer because of the clothing and social life, but women are always considered second class. But in terms of education and awareness, I think women are ahead".

Fidan, who works for the HDP Samandag Office, makes a similar point:

"When compared to other Islamic groups, Arab Alawite women are definitely freer and more independent. We are a lot more liberal with our clothing, going out, the way we talk, from what I have seen personally when it comes to Sunni women. My relative lives in Ankara, but she can dress more openly here. I am not exactly sure why this is the case, why we are freer, but it's like that. Of course, we have our problems, women are oppressed everywhere. I should correct this, we are not very liberated, but we have more freedom compared to Sunnis. We have our problems, too, women face lots of pressure from society. For example, a woman is subject to domestic violence, but she keeps it a secret, because she doesn't want to lose face".

${ }^{83}$ Kirikhan is one of the Sunni majority districts of the Hatay province. It is home to different ethnic groups such as Kurds, Turks, and Circassians.

${ }^{84}$ Alawite girls used to be married off at a very young age, as early as fourteen, but this marital practice has significantly decreased within the past two decades. It is however understandable that the generation who experienced this era is more skeptical of women's empowerment within the Alawite society. 
From these two statements, we can infer that as a consensus Alawite women recognize that they still have not reached gender equality in their society, yet they enjoy more freedom in comparison to Sunni women. This is a crucial point, because Alawite women construct their identity based on this conception that they are "better off than Sunni women". It is also important to remember that Alawite women live in a Sunni dominant society, therefore the act of dressing becomes a key outlet for challenging the Sunni hegemony in an embodied way. This specific identity construction in relation to place (and in relation to others in that place) reminds me of Edward Said, as quoted by Massey:

"With regard to the consensus on group or national identity, it is the intellectual's task to show how the group is not a natural or go-given entity but is a constructed, manufactured, even, in some cases, invented object, with a history of struggle and conquest behind it, that it is sometimes important to represent" (Massey, 1994: 6).

I use this quote to suggest that just like the way more Sunni women in the Muslim Middle East decided to wear the 'hijab' as a reaction to the West after September 11 and the consequent "War on Terrorism", in Antakya more Alawite women are taking pride in being 'open' women and being present in the 'public' sphere. Hence, as Said said, group identities are always constructed and often are a response to certain oppressions or historical struggles.

I would like to end this section by stating that for the most part, Alawite women are aware that freedom in dressing does not translate into freedom in other 
aspects of life. They, too, suffer from domestic violence, unequal pay, and a plethora of other differential treatment based on gender, but they are relatively "better off" when compared to women whose cultural codes they regard as "more oppressive". When confronted with a pushback on Alawite women's seemingly empowered status, women often pointed to the fact that "gender equality is not even a reality anywhere in the world", thus demanding a gender analysis within the context of Turkish society and the Muslim Middle East.

\section{The Construction of Arab Alawite Women as Religious and Sexual Deviants}

In this section I discuss the discourse on Alevi women in Turkey, which include Turkish and Kurdish Alevis and Arab Alawites. I decided to look at the category 'Alevi women of Turkey', because it is difficult to filter out the ethnicities from the discourse, and because Alevi women of all three ethnicities experience similar views on their sexuality. Discussions around the (uncovered) body, piety, morality, and sexuality are crucial parts of the feminist analysis of the private/public. Dressing the body is charged with important signifiers and is indicative of female empowerment, as having a choice in dressing also means having autonomy over one's own body. Hence, this section compliments the overall discussion of this chapter on female visibility in the public sphere, embodied resistance to hegemonic masculinity, and women's social/political/economic empowerment. 
Before I go into the discussion of Alevi women's bodies, I would like to define concepts of ethnicity and sexuality according to Joane Nagel (2003), as they are crucial to understanding the imaginings of Alevi women. Nagel defines ethnicity as the "differences between individuals and groups in skin color, language, religion, culture, national origin/nationality, or sometimes geographic region. Ethnicity subsumes both nationalism and race" (2003: 3). She indicates that race and nationalism are "two major forms of ethnicity, and describes nationalism as "a particular kind of ethnically based social identity or movement generally involving claims to statehood or political autonomy, and most often roots in assertions of cultural distinctiveness, a unique history, and ethnic or racial purity" (2003: 3) She also writes how "ethnicity is not fixed, unchanging feature of social landscapes or individual biographies. Rather, the extent and meaning of ethnic differences are socially defined, historically and situationally changeable, and sexually loaded" (2003: 38). And by sexuality she refers to ''men' and 'women' as socially, mainly genitally defined individuals with culturally defined appropriate sexual tastes, partners, and activities" (2003: 8).

In December 2014, a conference titled “Women in Belief, Social Sphere and Alevism" was held in Ankara University. A first of its kind, the conference was organized by the expert on this topic, Dr. Bedriye Poyraz. In an interview she gave to an online news source ${ }^{85}$, Dr. Poyraz revealed some important insights on how Alevi

\footnotetext{
85 https://www.evrensel.net/haber/101313/aleviler-de-kadin-erkek-esitligikonusunda-kendileriyle-yuzlesmeli
} 
women (including Turkish, Kurdish and Arab) are perceived by Sunnis in Turkey. By using the Dersim Rebellion/Massacre of 1937-38, she claims that "the separatist mindset is trying to claim victory over women's bodies". She draws a connection between the political and psychological war on women, instigated by the state, during the Dersim Massacre and today. In the interview, Dr. Poyraz states:

"In my presentation, I analyzed how Dersim reports and newspapers discussed Kizilbas (Alevi) women. While I was researching the Dersim Massacre, I noticed how women were discussed. Before the massacre, there were official reports written and prepared... They describe Kizilbas women from Dersim as loose, seductive, satanic, and force of all evil. Before being killed, women in Dersim were raped first. The Dersim Massacre is a tremendous trauma, cruelty, massacre, slaughter. It is possible to see what would be done to Dersim women in the pre-massacre reports. Women are simultaneously viewed as objects of desire on one hand and the enemy on the other. This started coming out with the Dersim's Missing Girls folder."

During the Dersim Massacre, Alevi women were simultaneously viewed with desire and disgust. The female "Other" is constructed as impure, perverted, hypersexual, or promiscuous, which also helped legitimize their rape. The construction of the "Other" is often based on binaries and "are remarkably consistent as one listens to ethnic discourses around the world...: our purity versus their filth, our honesty versus their chicanery, our chastity versus their debauchery" (Nagel, 2003: 39). Dr. Poyraz continues:

"They made women servants, sex slaves, sold them and even made them their wives. They have created a trauma that is still reflected onto today. Just like with Armenian women, we are just now finding out that important general and politicians' wives are from Dersim. For example, they are saying 
that Kenan Evren's wife is from Dersim. This is a strong possibility. It would not be surprising if it were true. We see a similar kind of violence today. Whatever the soldiers, military officers did to women of Dersim, that is what ISIS did to women they don't consider one of them. In reality, the conflict is carried out over women's bodies. We know from women's studies that there is this idea that no victory counts as victory unless it is won over women's body. This trauma is exacerbated with the cruelty inflicted on women".

Through this statement, we see how Dersim women's bodies become sites of nationalism. According to Nagel, ethnic boundaries are also sexual boundaries, which are also national boundaries. During the Dersim Massacre, these boundaries were crossed and Alevi women's bodies were claimed, conquered, and marked.

Today, Alevi women are continuously perceived as the Other, the religiously deviant. They are also viewed as "loose" or "promiscuous", at times because of the way they dress (not wearing the tesettur) and at times due to the more relaxed family and cultural codes. For example, a Turkish Sunni from Antakya, Hakki tells me that Alawite women are considered "loose", because "they don't really have this understanding of 'namus' (honor) or virginity," he says. He adds, "Arab Alawites are very comfortable; I went to a girlfriend's house at night and her father didn't say anything. Late at night, Alawite women walk around alone (kadin basina), women and men sit together and drink alcohol". In Hakki's perception, women who are in the streets after-hours and without male accompaniment, who can bring guys home in their fathers' presence, who socialize in mixed-gender settings and consume alcohol are 'loose' and have no 'honor'. 
Feminist activist Leyla says of Arab Alawite women: "Alawite women are perceived as loose and deviant, they walk around at night without the company of men". Nagel writes that this is the case because "The sexual ideologies of many groups define members of other classes or ethnicities as sexually different from, usually inferior to their own normal and proper ways of being sexual" and "These class or ethnic "Others" might be seen to be oversexed, undersexed, perverted, or dangerous" (2003: 9). The excessively feminine, uncovered Alawite woman is 'oversexed' and considered 'hypersexual'. Nagel expands:

"This pattern of contrasting valorized dominant group sexuality with devalued nondominant group sexualities can be found in descriptions of ethnic relations around the world. Sexual stereotypes commonly depict 'use' as sexually vigorous (usually our men) and pure (usually our women), and depict 'them' as sexually depraved (usually their men) and promiscuous (usually their women)" (2003: 10).

For example, Selda tells me that Alawite girls were approached more by boys, because they were considered 'easy' and more likely to engage in sexual activities:

"I had a girlfriend from Samandag in my class and other Sunni boys who were unrefined wanted to be her boyfriend. They were trying to use her and then would talk behind her back, because they see her as an 'easy woman' because she is Alawite. This really bothered me and it was at the same time when I became politically organized... At that time, I was more focused on student problems and Arab Alawite identity, not so much on women".

Nagel defines these types of sexual advances towards the "Other" as "ethnosexual adventuring". She explains: 
"Sexual contact across ethnic boundaries is not always a long-term affair, and it is not always a welcome advance. Recreational sex with and sexual abuse of member of other ethnic groups are the specialties of ethnosexual adventurers and invaders. These forms of hit-and-run ethnosexuality, especially adventuring because of its relative ease and casualness, are at least as common, possibly even more common, historically then are ethnosexual settling and sojourning for several reasons... Ethnosexual adventuring and invasion also are most common than settling or sojourning because they are relatively easier and more convenient. Ethnosexual adventures and invasions are short-term and noncommittal enterprises, involving little investment of time or resources" (2003: 17-18).

She writes that ethnosexual adventuring is often based on stereotypes of "the Other":

"Ethnosexual adventuring and invasion are common features of political economies of desire which depend on stereotypes of the sexual talents or characteristics of members of particular races, ethnicities, or nationalities. Assertions of the impurity, inferiority, or hypersexuality of ethnic Others often are used to justify ethnosexual invasions including rape, forced sexual servitude, and trafficking in women or children for sexual purposes" 2003: 19).

Emin, a young Arab Sunni lawyer from the district of Altinozu, primarily dates Arab Alawite women. When I ask him why, he says they are "more liberal" and they "think more freely". He thinks there is greater gender equality among the Arab Alawite community. He also tells me that in Arab Sunni communities, only until very recently women and men started sitting together at weddings or at home. "It's the modernization effect," he says. There are also Sunni men who date or marry Alawite women for other reasons. Delilah from Harbiye tells me that it is considered a religious deed for a Sunni man to marry an Alevi woman. "It's as if he is saving her, he is bringing her to the right path," she says. 
During a conversation over tea at an old Antakya café, a Kurdish Alevi teacher who was appointed to Antakya told me that before she came here, she thought Arab Alawite women would be more empowered. "But it is only how it seems from the outside, not really the reality, and they are sexually objectified," she says. Amina believes there is a difference between Alawite men and Sunni men and how they look at women in general, and Alevi women in particular. She believes being too conservative makes men more likely to objectify women:

"I think that Arab Alawite men see our women as modern and open and that Sunni men see us as 'loose', but I think this has something to do with the belief system... I really think that when Alawite men look at women, they don't envision them naked. Let me put it this way, I think there is a huge difference between a religious Alawite man and a religious Sunni man and the way they view women. I don't want to generalize, but I have a negative experience with this. For example, after the namaz, an Alawite will be so in touch with God that he won't see a woman as a woman. But an old man, my grandfather's age, who just came out of the Friday prayer in Kusadasi told me, 'God damn you, you will make me lose my path' and I was wearing very modest clothing. There are women walking around in bikinis. I was waiting for my husband near the mosque. I will never forget this. I have experienced many things like that. A man who has a wife all covered up, looks at every part of my body while talking to me. Educate yourself first. I don't mean to generalize, I don't like to discriminate, but really I have never seen an Arab Alawite man looking at a woman like that right after the namaz".

Alevi women's construction as the Other, who is loose, promiscuous, deviant, and desirable at the same time is not a new phenomenon. As Dr. Poyraz's study shows, this is a widely held perception among Sunnis for many decades, perhaps even centuries. Nor is this a phenomenon unique to this region; ethnosexual frontiers were built and crossed all over the world, from Yugoslavia to the Americas. Women's bodies continue to be sites of war, violence, and nationalism. As for 
Alawite women, the war on their bodies continues on multiple fronts in Turkey and in Syria.

\subsection{Reiterations of Modernity, Secularism, and Democratic Values}

\section{Democracy from within: Arab Alawite Familial Structure and Women's}

\section{Right to Speak}

During a conversation with Alawite scholars in between workshops at the Arab Alawite Conference, a professor from the southern city of Mersin asked the group: "What brings us together with other Alevis; is it religion or our democratic structure?" I was struck not by the answers to this question, but by the question itself, as it displays the self-recognition of Alawites as 'democratic'. Alevis have historically been considered a more democratic and secular group in Turkey (Kocan \& Oncu, 2004; Dressler, 2008; Kose, 2012). Antakya lawyer Yeliz makes a connection between this democratic structure and women's right to speak:

"Arab Alawite women have more freedom, are highly educated, progressive, democratic, and have a voice. This is because they are raised this way and are regarded more equal to men and the family puts importance on education (for both genders)".

Ceren, also a lawyer from Antakya, agrees:

"My mom always expressed herself. This is the case with most families around me. Of course, it's not perfectly equal, but it's much better in our culture. Of course, there some differences, but in general, whether rural or urban, (Alawite) women are stronger, they have more say".

Landscaper and previous politician Halime also points to the democratic values of the Alawite community, starting from the family: 
"My family is very democratic, we were treated equally. My mom also. I definitely think this affects women's politicization, the equal treatment of women and democratic family structure. It's definitely a cultural thing and one of Alawism's superior features... That's how I feel as a woman, because I am free, was raised democratically, I am enlightened, and I've experienced gender equality. My traditions haven't oppressed me as a woman. So, I am fortunate and happy".

Naciye, Sunni political and feminist activist from Ankara, married into an Arab Alawite family and has been living in Antakya for over forty years. She offers a unique perspective as both an outsider and insider. She makes a comparison between the Turkish/Sunni family structure she grew up in, and the Alawite family structure she has experienced:

"Arab Alawite women are more open to questioning. My own family is traditionalist. Alawites have a more democratic family structure, also when it comes to education. That's why women have almost equal status at home when it comes to speaking their minds and the decision-making process. This differs from the traditional Turkish family structure. You can consider me both an outsider and insider. I've been living here for forty years, I am an educator, a socialist, and a women's activist. I give talks about women on behalf of women, so I have to be more objective".

Singer and teacher Sevgi also draws on comparisons between her experience growing up in an Alawite family and what she has observed in Sunni families:

"I do think we have more freedom and can express ourselves more comfortably. I think it's cultural. I stayed at the homes of my Arab Alawite friends as well as Sunni friends. With my Sunni friends, their relationship with their parents is like an army general, more authoritarian. It's not like that with us. I can ask my dad to hand me a glass of water in front of my friends (without a problem)". 
Feminist activist and HDP politician Songul stresses the importance of cultural practices that have been passed down, which allow for a more democratic environment in the Alawite community, and provide a steady foundation for achieving higher gender equality. She argues that Alawite women are more politically active due to this democratic structure. She claims that this is rooted not in the Arab culture, but in the Alevi/Alawite culture:

"You are right in the sense that it has to do with the culture, why Arab Alawite women are more politically active. This isn't due to Arabness, but due to Alawism, like we said earlier, it's a more democratic structure. When women are participating more in the public domain, they are able to see the inequalities and discriminations. So, oppressed women become aware of their oppression and try to find ways to fight it. When you feel constricted by the state or men, you try to find solutions in an amateur way. Women's associations are more professional ways to find solutions. So, when you are already not very religious or strict like the Sunni sect, this enables you to enter the domain much easier. I am pretty sure that the problems Sunni women express at a feminist organization is much more than the problems women face here. But this doesn't mean that there are no problems here".

Naz, a feminist activist and organizer, agrees: "Arab Alawite women are ahead and it has to do with culture; they can express themselves, are educated, can go out on their own, can drink (alcohol), can be in mixed gender settings". During the allfemale focus group in Harbiye, women expressed similar sentiments. Below is an excerpt from a discussion on 'freedom at home' and how Alawite families raise their children: 
Participant A: In other places, it is impossible for a group of women to go out at night and have beer or rakl ${ }^{86}$. This would be considered a sin or they would be stoned. This doesn't happen here. Why? Because they give us that freedom at home. They let us taste. They don't tell us that it's a sin, that we need to stay away from that. Since we grow up with that freedom, even when we went to the university, we never get out of control. This is not taboo for us. That's why we appear as strong women in society.

Participant B: This doesn't count for everyone. Not for uneducated people.

Participant A: Yes, but it's true for most.

Participant C: If you suppress your kids, then with the first opportunity they have, they will get out of control. We don't have that, because we are very easygoing and it's part of our daily life. Therefore, when we are away from our family, we don't have the desire to indulge. I think that's why our women feel strong and can easily express themselves outside.

Participant A: Women go out at night, it's normal here.

Feminist geographers have successfully collapsed the private-public binary and the association of the public with masculinity, and deconstructed how gendered power gets articulated in private and public spheres (Staeheli and Kofman, 2004 in Staeheli, Kofman and Peake, 2004). From the above conversation, we can see how Alawite women similarly collapse the private-public dualism by stating that Alawite women are free to act, in this case consume alcohol, both at home and in public, thus breaking down the public-male-alcohol association. By consuming alcohol in public, Alawite women are claiming power in social settings. This specific example helps us to "situate power in networks or in webs of relationships", in this case the

${ }^{86}$ Rakı is an unsweetened, anise-flavored alcoholic drink that is popular in Turkey, Greece, Iran, Turkic countries, and in the Balkan countries as an apéritif. It is often served with seafood or meze (appetizers). Arab Alawites in Antakya are known for producing their own rakl at home. 
empowering act of consuming alcohol in public, as women, in a Sunni dominant society (Staeheli and Kofman, 2004: 7).

On another occasion, I was visiting Besime at her home in Tekebasi, Samandag. I had just finished interviewing her mother, when her father walked in and stroke up a conversation about Alawism. We were all sitting in the living room, the mother, three daughters and Besime's male friend, when the father insisted that I try his homemade raki. Everybody in the room received a glass and a fresh fruit platter from the garden. While this was not the first time I was in an Alawite household where families socialized and consumed alcohol, I had to stop and take that moment in, because I (re)-realized how this scenario is very rare in a nonWestern part of Turkey. Besime later told me how her father had given his children raki when they were fourteen years old, saying, "you will eventually drink outside, better you learn how to drink at home first".

The tendency to drink in mixed-gender setting does not seem to be a new trend. Teacher and folk musician Necmi tells me about the concept of "aksamlama", which derives from the word "aksam" (evening) and the literal translation is "to evening". Dating back generations, this concept refers to the gathering of family and friends, who spend the evening conversing and singing folk songs. In these environments women and men socialized and drank together. "Just imagine, this kind of inclusive setting for women existed in a faraway village of Antakya forty years ago," he exclaims, clearly impressed and proud of the 'open-minded' and 'progressive' traits of his people. He adds: 
"This (mindset) is embedded in the cultural codes of our community. It dates back to pre-Islamic time. I think it also has to do with being coastal people and the climate. This code is thousands of years old and even though it has been eroded a bit through Islam, it still continues. I think this is why we have more gender equality".

The perception that being open-minded, progressive and gender inclusive is "in the genes" of Alawites is widely held within the community. While it is an essentialist argument, it is one of the cornerstones used to argue how the Wahhabi-Salafist (ultraconservative) understanding of Islam, even Sunni Islam, has been oppressive, especially towards women.

Self-made journalist Birgul shares Necmi's opinion on cultural codes and how Alawite culture differs from Sunni culture. She also keeps the religious aspect separate, which she defines as "exclusionary to women", and bases her case on the democratic structure within the Alawite family:

"I think the reason that Arab Alawites are more liberal and open-minded has to do with our outlook on life, which is connected to our culture. I think some Sunni families are still very strict, but they are softening up. Maybe it's because they have been living amongst us. I think it has to do with your perspective on life, and Alawites are more modern, they value women... especially when compared to Sunnis. Even though men seem to be the chief of the house, it is actually women behind it. Why? Because of sharing. Men share their problems at work or home with women. I think this act of sharing shows that Alawite value women more. I don't think it is connected to religion. Women are not really included in religion". 


\section{Religious Aspect: A Blessing in Disguise}

Gülfer Akkaya is getting ready to publish her book Yol Kadindir, which translates as “The Path is Woman”, and investigates women's place in Alevism. While conducting research for her most recent book, Sir Icinde Sir Olanlar: Alevi Kadinlar (The Secret within the Secret: Alevi Women) (2014), Akkaya noticed some contradictory statements, which paved the way for her new book. Yol Kadindir is driven by the question, "are religions and beliefs sexist?" and argues that the roots of Alevism are womanist and that Alevism has become relatively sexist after a series of interventions over the years. Even so, Akkaya believes that once you "wipe off the dust from the past", you see that "in Alevism everything is womanist".

In Chapter 3, I explained in detail that many scholars argue how monotheistic religions are oppressive towards women and that Arab Alawism is no exception. Many Alawite women I interviewed agreed with this statement. In the chapter, I also discussed in detail how women's exclusion from certain religious spaces and practices in Alawism is regarded a "blessing in disguise" by many Alawite women. In fact, women's exclusion from religion was one of the most common answers given to my question, "Are Alawite women more empowered compared to other women in the region?" Most interviewees could not deny the deeply entrenched patriarchy in society, but they still believed they were "better off" than Sunni women.

Alawite men were also in agreement with this verdict, and they largely tied it to women's religious exclusion. While browsing around a souvenir shop in old 
Antakya, upon finding out my purpose in Antakya, the owner told me, "Our women have more freedom, because they are distanced from the Islamist religious mentality". On a different occasion, I was having tea with a language school director, when one of his male friends, also from Samandag, came in and joined in our conversation. The visitor had strong sentiments against religious order, which he claimed "enslaved" people, and believed that Alawite women were spared from this type of enslavement. He added, “With us (Arab Alawites), women's freedom is not something that had to be fought for, this has always existed in our culture. In villages, women are even freer; in the metropolis, people can become more conservative". He was referring to how interacting with Sunnis or more conservative groups in the metropolis bore the threat of Sunnifying Alawites.

Alawites often use Sunni women's experiences, or at least their perception of it, as a measuring stick for their own freedom and empowerment. Recent university graduate Gulizar from Samandag compares Alawite women's experiences to Sunni women, but is not that certain why Alawite women have more freedom. It is almost as if Alawites have this common, almost automatic, perception that their women have more freedom, but do not always have the words to describe why:

"Yes, I am aware that Arab Alawite women have more freedom, are more independent, and farther ahead in general, but I would have to think about the reasons for that. We could say that yes, all religions are patriarchal and yes, all religions put pressure on women, but when compared to Sunni sect, I think Alawism is less oppressive towards women. They are not as strict as Sunnism, or another religion, I am not sure what else I can compare it to". 
Leyla bases her explanation for Alawite women's increased freedom within the

Alawite belief system, which she views as a humanist institution:

"The reason why Alawite women are ahead of women from other groups here can be explained in two ways; religion and economics, or socioeconomics. When compared to Sunni/Hanefi women, Arab Alawite women, as well as Anatolian Alevis, are more relaxed. I think this has to do with the fact that Alawism is not a conservative and backward religion, but they recognize a direct connection between God and human. There are no intermediaries in Alawism. When looking at other religions, we see imams ${ }^{87}$ or other religious persons acting as intermediaries. This does not exist in Alawism. That's why I think the individual is more lenient due to this direct connection to God. For Arab Alawites, the most important thing is to get along well with others and make positive connections with others on a daily basis. They have a belief system that is built within an ethical framework, no stealing, etc. If God exists, s/he would want us to enjoy the opportunities on earth. My father is also a sheikh and my mom a sheikh daughter, our fasting is twelve months ${ }^{88}$ a year, and it's not refraining from eating, but from bad habits. Of course, we do have people who follow the trend and fast by abstaining from food".

Instead of focusing on women's exclusion from certain religious practices, Leyla contextualizes the relationship between women and Alawism within a humanist framework. This framework provides the explanation on why Alawites have relatively higher gender equality. Leyla's explanation echoes other Alawite women's statements on Alawism/Alevism as a humanist religion, or sect, which already in a way places women on a level equal to men.

\footnotetext{
87 Prayer leader.
}

${ }^{88}$ She is referring to Ramadan in Sunnism, which is for one month every year. 


\section{Secularism and the Leftist Movement}

In the previous chapter on Alawites' involvement in the leftist and socialist movements in Turkey, I explained how these movements were highly inclusive of women. The class-based approach of such movements and disregard for ethnicity, religion, and gender provided a political space for Alawites, and other minorities alike, to express their identity, paving the way for Alawite women's politicization. This is not to say that leftist and socialist organizations had achieved gender equality, on the contrary there was often tension around gender and pushback from women, as I partially explained in Chapter 4 . These women were aware of their marginalization through patriarchy that is found in Marxist and socialist ideologies (Bryson, 2004). I will offer a more in depth analysis of the feminist critiques of the Left in the next chapter. For now, I would like to focus on why Alawite women believe that leftist movements have contributed to their politicization.

Many interviewees used the leftist political history to explain why Alawite women in Antakya were not only more political than other women, but also more empowered. This leftist history is also interwoven with secularist ideologies, adding another layer to the discourse of women's empowerment in the Alawite society. For example, Selda believes that the politicization of Alawite women is what truly has empowered them, more than the cultural aspect:

"I don't believe what liberates us is Arab Alawism itself. In the Alawite tradition, there is socialism. I think women also began questioning their rights because of this. And there are many women in Antakya and Samandag who are revolutionary. They paved the way for others. They paid some price. 
I think this has had an effect on why Alawite women are more liberated compared to Sunni women. I think it's political. Of course, culture has an effect as well, but I think politics has more to do with it, because what I told you earlier are things that pacify women. Women can express themselves more freely, compared to Sunni women. In this country, Alevis have died, but 'covered' women have mostly fought for turban rights. I don't minimize any struggle, but this is how I see it".

Alawite men, too, argue that "Alawite women are secular and have more freedom compared to other Muslim or Anatolian women," as stated by musician Necmi. Previous leftist activist Tahir, who spent twelve years in prison after the 1980 coup, says that Alawite women have more freedom compared to Sunni families not because of "the lack of religious pressure, but because Alawite culture is more secular, more flexible when it comes to women, and women have more freedom of expression".

Since the beginning of the Turkish Republic, Alevis have been avid supporters of secularism and jumped on the modernization train after the 1970s. Can (2011) explains how Alevis have aligned with secularism with hopes for equal citizenship with equal rights. She writes that although Alevis were perceived as a threat by the state during the rightist-leftist conflict as "communists and supporters of Kurdish nationalism", with the end of the Cold War this has changed (2011: 63). Nowadays, Alevis of Turkey are perceived as a "Kemalist, secularist, and democratic" group who are against Islamic radicalism and the 'Kurdish threat'. As a result, Alevis have shouldered the mission of being the carriers of "modernity" and “progress" (Can, 2011: 63). 
The proclamation of the Arab Alawite Conference held in November 2015

includes the statement of the Secularism and State Relations Workshop, which reads:

Article 5- We have a critical approach towards the past and present secularism model. We emphasized that we do not want such an enunciation of laicism, but instead one in which the state takes an impartial position and where religion and state are two separate and independent institutions. State and religion need to disengage legally and institutionally. We need to transition to a system where the conventional understanding of the state is left behind and where all belief groups have a democratic platform.

Article 6- In this country, the struggle for equal citizenship should be our primary goal. We need to demand the elimination of the current religion classes and the right to education in our native tongue.

This statement conveys the demand of Arab Alawites for equal citizenship and their vision for a truly secular state, where religion and state remain separate. The conference reiterates Alawites as a secular and democratic stronghold in the country and echoes the fears of secularists alike regarding the Sunnification of the education system.

In short, while my Alawite women informants are aware that their marginalization continues within leftist organizations, they strongly stand by the belief that leftist and socialist platforms have been integral in women's politicization in Antakya. They continuously challenge the patriarchy and transform the masculinist atmosphere within such organizations through various women's initiatives, I will explain in the following chapter. 


\subsection{Socio-economic Factors: Waged Labor and Female Education}

\section{Domestic Workers and Wage Earners: Arab Alawite Women's Role in the}

Household Economy

"Women are decision-makers at home, they work at home and also earn money. So, there is a confidence that comes from that. The task distribution at home... it's less than in other communities. My aunt will tell my uncle, 'go and make the salad' and my uncle will not get mad about it and will go and do it." - Selda

Women's employment outside of the domestic sphere is a topic that has received a lot of critical attention from feminist scholars (Elson and Pearson, 1981; Massey, 1994; Rankin, 2001). While the neoliberal perspective would argue that women's economic gains is a source of liberation, such feminist scholars have shown that this is not always the case. Elson and Pearson write;

"Liberals have always tended to see jobs for women as leading to female emancipation by providing women with financial independence; and have viewed the lack of equal pay, equal working conditions and equal opportunities for women in the capitalist economy as the result of outmoded prejudice and discrimination" (1981: 97).

Classical Marxists argue that women's incorporation into the work force merely substitutes one form of domination for another, meaning the replacing of "the rule of the husband over the wife" by "the domination of capitalists over worker (Elson and Pearson, 1981: 97). In many cases, women's subordination was not swapped at all, but doubled. Massey's (1994) case study in Durham, England during the nineteenth century shows how women's employment in the factories rose, while 
men lost their mining jobs. Suddenly, men were home watching the kids while women were earning a wage in the factories, which "turned the home upside down" (Massey, 1994: 194) and "demanded a re-assertion of male authority" (Hall, 1982:

27 quoted in Massey, 1994: 196). Women's growing economic power has and continues to be a threat to male authority in many societies, contributing to women's subordination. This also happens in the work place, where women's growing presence in high-status fields creates a perception of an "identity threat" for high-status men (Kricheli-Katz, 2013). Men who feel threatened react by derogating high-status women. Yet another argument is made for the financial power of women, such as microloans. Rankin (2001) argues against the popular view that microcredits are empowering women and demonstrates how it is in fact a gendered practice that does not always empower women, but perpetuates gendered job divisions. According to Rankin, supplying women with cash does not automatically translate into increased independence and emancipation.

All this is not to minimize or dismiss women's employment outside the domestic sphere, especially since the majority of Arab Alawite women would argue otherwise. For example, former Progressive Women's Association member Burcu strongly believes in economic independence: "Economic independence is very important. We put a lot of importance on education, but it's not enough. My mom didn't finish Harvard or Oxford, but she earned her own money. For me, it was very important to be a teacher, a woman activist, and a mother". In her opinion, waged 
work can go further than education, especially in agricultural societies such as Antiochian Arab Alawites.

Alawite women feel very strongly about their participation in the household economy which dates back. They interrelate their strength and right to speak to their economic power. Arabic teacher Gulsen says, "Women have always taken part in production and workforce, that's why they are strong and have a say". Folk musician Necmi believes that agricultural production has set Alawite women free. "When I was born, my mom left me in my crib and went to work in the field. Arab Alawite women aren't just child bearers stuck in the house, they have always been part of production. Men weren't on their own, they did it with women... Religion couldn't penetrate cultural codes, because women have worked as much as men," he says. This is why Arab Alawite women have more freedom, he claims. Samandag councilwoman and financial consultant Bahar is in agreement with Necmi:

"Arab Alawite women have always been ahead. This is because women and men have been in production together, they worked together, earned together and spent together. There might be some differences in terms of class, rural/urban areas, but I still think it's that way in general... Women's figure in the social sphere is strong. This has to do with production relations. Our grandmothers and grandfathers did farm work together. This has created a relatively less hierarchal structure, it is more equal".

Such narratives reinforce the idea that Arab Alawite women have been historically more present in the public sphere via waged labor, hence suggesting that they have been more "active" citizens. While feminist geography complicates the division between "public" and "private" citizenship (see Massey, 1994; Yuval- 
Davis, 1997; McDowell, 1999; Staeheli, Kofman, and Peake, 2004), it is an important point to consider in understanding why Alawite women construct themselves as empowered and active citizens. Also, retelling the narrative of Alawite women as wage earners and their visibility in the public and labor sectors can be read as resistance in an era where women are feeling the pressure from the state and the oppressive masculinist mentality prevalent in Turkish society.

To illustrate my point, I will share a specific interaction I had. I was invited to a Ramadan dinner at a Sunni family's house, which gave me the opportunity to get some 'outsider' views on Alawite women. Interestingly, the Sunni family thought that Arab Alawite women were oppressed. The eldest son of the family, a successful scientist with a Ph.D., told me that Alawites "make women work in the fields" and this was a sign of "oppression and exploitation" of women, considering Alawites in general were wealthy. He said, “They don't distinguish between men and women when it comes to work, their women are very hardworking... They always work in their gardens, fields, even if the men earn money elsewhere. Why doesn't the woman just sit at home? They are already well off". When I told him that this type of work felt empowering to many Alawite women, he called it "false consciousness": "Women are fooled into believing that they are free and equal, but it's actually oppression and exploiting women. It's due to being Arab, not due to being Alawite". I was struck by how one phenomenon could be interpreted so differently, depending on who was doing the interpretation. 
As another outsider, but a highly conscious feminist and socialist activist,

Naciye has quite a different interpretation than the one above:

"Means of production determines the economy. (Alawite) Women have always been in production along with men and therefore they also have a say. If men are working elsewhere, women continue being productive in their gardens and earn money. So, she participates in the economy democratically, therefore she democratically has an equal say. They come from a system of production. This goes both for urban and rural communities. It doesn't matter if they moved from rural to urban, they never lose touch with earth. They live in the city but they continue harvesting in their village gardens. But in a traditional Sunni family, women don't have that much say. Usually the father, men dominate all family affairs. Women have little or no say. Alawite men and women sit together, dance together, drink together, they are side by side in daily life. If we put it into percentage, in a Sunni family, women would have $35 \%$ say, men $65 \%$, while in Alawite family this would be $50 / 50$, or perhaps $45 \%$ women and $55 \%$ men. I am saying this also based on my own family. My mother couldn't raise her voice or show affection to her children or eat before her father-in-law. It was a big family. It was like that. So, when I compare it to families here, there is a very different scenario. This is due to the traditional structure of Arab Alawism, it is more democratic".

Here we see a classic liberal feminist argument that inserting women into the (capitalist) system will automatically empower them. As I have discussed above, feminist geographers have critiqued this argument, particularly the scholarship on women/gender and development, and have shown that waged work and inclusion in the capitalist system does not always equate with gender equality and women's emancipation (Pearson and Elson, 1981; Rose, 1993; Kabeer, 1994; Schroeder, 1997; Radcliffe, 2006; Sharma, 2008). And many Alawite women are aware of this reality. Feminist activist and HDP politician Neriman admits that 'economic empowerment' does not necessarily mean 'women's empowerment'. Aside from the perpetuation of issues such as the gender wage gap, gendered labor, women-as- 
threat to males, and masculinist/patriarchal work environments, she digs up all sorts of other problems Alawite women have, but are not so willing to discuss, because of their fear of tainting their image as the "free and independent woman":

"Yes, in that sense Arab Alawite women have more freedom than other groups, but at the same time, Alawite women keep their problems within their homes and don't tell anyone. I've seen many cases of forced sex within the family, sexual harassment. I personally know about one hundred women who have endured such things, but don't say anything. Women don't consider these things as violence. They think they are free and comfortable, but this is not the case. And this is so widespread. I think if women were more in religion, perhaps this would be worse. I remember my mom being black and blue and she used to tell us she fell off the olive tree or the ladder, but I am finding out now that it was my dad beating her. If you look at my mom from the outside, she speaks her mind, she earns her own money, she works, goes out, spends her own money, etc. But it is all subject to scrutiny within the house".

Neriman believes that while domestic violence is a universal problem, the way women interpret it, digest it, and respond to it is different:

"Alawite women have difficulty talking about these issues, because they are embarrassed. Because they are supposed to be free and independent, so they cannot accept it. But Sunni women talk about this more easily, without feeling embarrassed. But Alawite women cannot even talk about this to their closest friends. Because they seem so free from the outside, they wonder why they are going through this".

A striking observation that emerges from her statement is the tension between the broader claim that many Arab Alawite women are more 'open' and 'free' compared to their Sunni counterparts and the claim that these 'open' women may sometimes be less willing to speak of domestic violence that marks their private lives. 
While Gulizar has a similar perspective to Neriman's, she stresses the fact it needs to be interpreted on a family to family basis. Her experience differs from the more general experience, because she comes from a sheikh family, which is more conservative and has stricter expectations from women:

"Do Arab Alawite women look like they are free and independent from the outside? I mean, yes, my mother is strong and all, but how powerful? She got married at age thirteen, had me with fourteen and became a widow with twenty. So yes, when looking from the outside, she is a strong woman. But her power consists of being able to stand on her feet within this system. But she is concerned about what other people will talk about our backs. Yes, she is strong, she raised us on her own and she is employed, but how much of her own path was she able to choose/walk? I mean, this is a specific case, she got married as a child and her life was formed within this framework. But the newer generation is more active. Here, whomever you ask, they will say that they align themselves with the Left, they are against conservatism. So, in general, Arab Alawite society is also patriarchal, but since the level of domestic violence is low, women are perceived as having more freedom. This has to do with the fact that women consider violence as being primarily physical violence (as opposed to psychological and emotional)... I want to reiterate the fact that the family I come from is conservative within the Alawite society. So, this is a personal/individual story".

There are certainly more conservative groups and neighborhoods within the Alawite society, which drastically changes women's experience with marriage, employment and education. Birgul, who is a journalist, grew up in a more conservative Alawite neighborhood in Antakya, in a low-income family. School was not an option for her for financial reasons, so she broke the taboo of working outside the house, with her father's consent:

"I've been working since I was eleven. I began working with Afghans who were in the leather business. I've been working for the newspaper for seven years, since it was founded. My family didn't have the means to provide us 
with an education. The teacher used to talk to my dad (to try to convince him), but he couldn't send us. He was the only one who earned money. He wanted to at least send one of us to school, but he couldn't. None of us went. I really had to convince my dad to let me work, because it was taboo for girls to work outside, they looked at you differently. It was a first in our neighborhood. Then other girls began to work as well. Once we started working, he never demanded our earnings, even though he didn't earn that much. But I wish we did have the opportunity to study, I think we would have been successful as siblings. In the family, my dad treated us equally, but the society didn't allow him to. For example, if my brother came home at midnight, it wasn't a problem, but if I was late from work for ten minutes, my dad was waiting at the door. Or if I walked with a boy or had a boyfriend, it was a disaster. So, this kind of differential treatment did exist. But we didn't have to serve the boys (in the family), just the father. We didn't begin to eat until my dad came home or we let him have the best part of the dish".

Birgul appreciates her father's treatment of the children in the household, allowing them to earn their own money and learn to stand on their own feet. Even though she admits that she would have loved to go to school, entering the work force at a young age gave her the skills to become the person she is today: an independent, divorced mother, who is a successful journalist with a middle school degree.

Birgul's narrative is an example of the diverse experiences of Arab Alawite women, which require an intersectional approach (Crenshaw, 1993; Nash, 2008), as class, income, location, and family shapes their lives differently. Birgul grew up in a more conservative, low-income family, but she was treated equally next to her brothers (at least within the household) and she gained economic power at a young age. I am reminded of what Engels (2010 [1884]) said about women and the family. He wrote that with the development of capitalism, the patriarchal system continued to benefit property owners, namely the bourgeoisie. Since the working class had no 
property, control of women was not necessary, implying that male/female inequalities within the working class are nominal. This may ring truth for Western societies (and during that era), but the reality differs depending on the cultural context. In the case of Turkey, where the Wahabi-Salafist ideology is clashing with the Kemalist and secularist ideology, the male/female inequalities are multi-faceted and much more complex. In a climate where AKP politicians are using intimidating patriarchal language, such as telling women not to laugh in public or saying that pregnant women have no business outside of the home, Engels' observation about the working class and gender inequality hold very little truth.

\section{Boom in Girls' Education}

"I think education is also related to economy. As you know, in times of crises, women are the first to work, because they provide cheap labor. Also, the fact that women want to enter the public domain. This is general speaking. But in terms of Arab Alawites, mothers who married off young want their daughters not to repeat the same mistake and send them to school". - Selda

Within the neoliberal discourse, education levels are considered a crucial indication of a nation's development status. According to the 2016 report of the Turkish Statistical Institute, Hatay is within the top 16 provinces in Turkey with the highest literate population, out of a total of 81 provinces. While I will not go into details of the neoliberal discourse on education, I did want to indicate that considering its geographical positioning and its highly illiterate neighboring provinces, Hatay is a shining star of the southeastern part of Turkey. If we were to further dissect Hatay and look at its districts, we will see that Antakya, Iskenderun, 
and Samandag are the highest educated districts, all which are concentrated Arab Alawite areas. Arab Alawite women overwhelmingly claimed that their society had one of the highest educated women in the country. This was also shown as an indication for their empowerment.

Social psychologist Berrin tells me that she read a report by Dogu Akdeniz Kalkinma Ajansi (Eastern Mediterranean Development Agency), in which they measured education levels in the Eastern Mediterranean region. The report indicated that the Hatay province had much higher education levels in the region, with differences showing between Arab Alawite concentrated districts and Arab Sunni areas such as Reyhanli and Altinozu. She says this is due to culture and necessities:

“In urban areas, education is more valued and girls aren't married off young. Also, it's harder to get a job with a high school degree. So, people want to guarantee a good job, so they want a good education. Families put a lot of pressure on their kids, girl or boy. Samandag people have a bit more money than Harbiye people. They will go above and beyond for the kids' education, even if it's a private college. But there are villages in Samandag, where girls cannot even leave the village, because there isn't even efficient transportation".

Berrin touches upon a valid point by distinguishing between urban and rural. Saime, who is one of 4 girls and 2 boys from a remote village, admits that in her village girls are not encouraged to study after middle school and are married off. This is because it is a rural area and there are not many employment opportunities other than agricultural production. Her family was an exception; her father wanted 
the kids to study because he did not have the opportunity to study. Her relatives also went to school, since the family overall placed great value on education. "My father thinks girls especially should study, because men can work at a construction site, but girls cannot," she says.

Kadin Emegi activist Naz said in her speech, "My mother had her daughters get an education so that they wouldn't depend on others". This perspective was amongst the popular answers I received. Event planner Nuray told me, "Alawites educate their daughters so that they aren't dependent on their husbands. This stems from the mentality that men can work anywhere, under all sorts of working conditions, but girls need to get an education". Theatre actor Melike agrees: "They think men would get a job no matter what, but women should get an education so that they are not oppressed". During the Arab Alawism and Women's workshop at the Arab Alawite Conference, participants discussed why women in Samandag had very high education rates: "Why are girls sent to school? Because men go abroad and get jobs, girls need to be educated so that they can stand on their own feet," one participant responded. Samandag Councilwoman Bahar thinks another reason is the "psychology of the oppressed", as they are trying to prove themselves and be selfsustaining. Nuray agrees:

"There is also the economic factor. Economic means were in the hands of Sunnis, as the agha system was common. Arab Alawites used to work for the aghas, they were very poor and oppressed. This gave birth to the psychology to overturn the situation and thus the need for education". 
Leyla also makes a connection to the past of Arab Alawites as a poor and oppressed society, which bore the will power to change their fate, to prosper and to increase their education levels when the first opportunity arose:

"The socio-economic aspect of it is the fact that Alawite used to be a poor society and they used to work in fields and that's why were called 'fellah'. Fellah is sometimes considered a religious labeling, but Alawites don't accept it, it was an occupation. Once the doors to Arab countries opened up, especially Saudi Arabia, people began migrating for work and Alawites prospered financially, especially after the 1970s. So, they began educating their kids, both boys and girls. The education level here is higher than most parts of Turkey. This affected women here, because they go to another city to study at a university, they live with other students and they bring back their new habits and cultural traits. I think this has a big effect. And being comfortable economically provides greater mobility. Women are able to go out more on their own".

During the Harbiye focus group, some valuable insight was shared regarding education among the Alawite society and why girls' education became so important:

Participant A: They (the state) didn't invest here. There are no factories. We used our minds, our strength, and put importance on our daughter's education. Our girls are even more educated than our boys.

Participant B: The problem wasn't really that girls shouldn't be educated, it was more about sending the girls to another region to study. But now this has also changed. There is this belief: men can make a living in any condition, but women can only save themselves and be independent if they study. If men don't study, they still can easily find a job, but if women don't get an education, they will be oppressed. In the beginning, they wanted girls to go to school nearby. But over time, as the examples increased, they began sending girls as well. Girls' education level and success is higher than boys, this is how I see it.

Participant C: Me, too. For example, I have two daughters that are one year apart. My older daughter wanted to study mathematics, but there were no mathematics departments in Antakya and I didn't want her to leave town. So, she enrolled in the primary education department at the local university. The following year, my younger daughter got into the business management 
program in Istanbul. I swear I sent her. My older daughter asked what had change since last year. It was that drastic.

When I asked when the change in girls' education happened, they said the change started 20-25 years ago, around the time the Ministry of Education implemented education campaigns for girls in the 1980s.

When I tried to get confirmation on this perspective, Antakya lawyer Ceren, who comes from an upper-middle class, disagreed:

"I don't think the girls' education has to do with the national education campaign, here they have always insisted on educating their girls. This is what I've seen. All my cousins are doctors, engineers, professors, all girls. I've never come across a family where the father didn't want the daughter to study. We have internalized getting a university education, opening the girl's future. My generation studied".

Nuray also believed that the importance on education among the Alawite community dates back, before the 1980s. She tells me that her father moved the family to Antakya from their village in order to send the kids to school. For Serdar, a restauranteur from Samandag, the reason why women are getting educated and are more independent within the past 20 years is related to men's labor migration. "Because women have to doing everything and they began sending their daughters to school. Without the presence of the father, there is less pressure on the girls," he says. 


\subsection{Male Labor Migration: Is There a Silver Lining?}

Studies on men's labor migration and its effects on the women they leave behind have found there is a positive association between men's migration and women's decision-making autonomy (Yabiku, Agadjanian \& Sevoyan, 2010), but a negative association with women's psychological well-being (Sultana, 2014), even if it meant significantly higher egalitarian gender roles (Wilkerson, Yamawaki \& Downs, 2009). Using a feminist lens on intra-household dynamics and power relations in cases of male labor migrations (Lawson, 1998), I have found that while men's absence doubles the burden of their wives and causes emotional distress, it also increases their decision-making autonomy and pushes them into the public sphere.

The transnational migration of men among the Arab Alawite society is very high. In my personal experience, every person I met had at least one family member who had at one point or another migrated to wealthy Arab countries, primarily Saudi Arabia. Sule Can's (2017) study on male labor migration from Antakya to Arab countries analyzes the hardships migrants are facing host countries and the torn families they leave behind. According to Can, after the 1973 Petroleum Crisis, which coincided with dire economic conditions in Turkey, Gulf countries were in need of labor and the working class in Turkey needed to work. While many Turkish citizens migrated to European countries, due to the shared language and cultural ties Arab Alawites overwhelmingly preferred Arab countries and began to migrate early 1980s (Can, 2017). 
Bahar explains the phenomenon to me as follows:

"When you look at the production relations today, we have labor migration. Men leave and women stay behind. This naturally pushes the woman outside the domestic sphere. Women have to shop, go to parent-teacher conferences. They have to maintain family relations on their own. One of every three people go abroad. I think the reason why there is so much importance placed on education is due to the psychology of the oppressed. We try to be selfsustaining... Other than economic factor, it (migration) also has to do with the geography. If we had lowlands or industrial development, maybe we wouldn't put that much emphasis on it. So where would our labor force work? In other parts of Turkey? That's difficult. In Hatay? That's even more difficult. This is the main reason for labor migration abroad. We are not an industrial city, we have the potential to be a touristic place, but still haven't reached that. We have great agricultural land, but it has been used badly at the time."

While Bahar highlights the deteriorated working conditions in Turkey as a reason for labor migration, Berrin also emphasizes the lack of options for youth and the dilemma they face, between education and working abroad:

"Our people have a remarkable dilemma between studying or going abroad. Nowhere else is this choice so drastic, they would have other options as well. So, if a kid has bad grades at school, he thinks, 'I better go to Saudi Arabia'. Because if he stays here, he won't be able to finish school and won't get a good job. Over there, they earn in foreign currency and there is no place to spend it, there is no social setting. So, this money is saved and they come back and buy property, etc. And the idea that he could get by doing a little farming on his land and have enough to survive is not good enough. So, this culture is shaped this way".

Berrin also conducted research on male migration in Antakya. Along with her team, she interviewed the wives of migrant workers and realized that there is a dominant narrative that needs to be challenged: 
"We are also conducting research with the wives of migrant workers. These women are left behind and they are left with the in-laws, the family, problems, and they also come up with their own solutions. This is usually talked about in terms of victimhood. I confronted this narrative during a meeting and said how can we know for sure, perhaps there are positive sides to it? So, we decided to conduct a scientific research. We have two scales and a questionnaire. The association helped us in reaching women. The research is being evaluated right now".

While Berrin did not go into detail of the study, her recognition of multiple

narratives is crucial. The dominant narrative is that male labor migration tears families apart and is a burden on the woman left behind. But what else is there?

Samandag accountant Yesim points out the good and the bad:

"The fact that men go abroad has made women stronger in a sense, because they had to be both the man and the woman. But I also criticize this, the fact that men work and send money home and women don't work and just spend the money. I don't see this as women's freedom/ empowerment. I don't agree with this... Samandag is coastal, it is more relaxed. I feel it is more matriarchal. Of course, there are women who are oppressed, such as my grandmother. But in general I see women as more dominant. One reason for this could be the fact that men are abroad. At least one of every three families send their men abroad. My mother felt the need to behave like a man because my father wasn't there. She was the authority at home, both mother and father figure. I was so used to my dad being gone that it felt normal. When he could come to visit, it felt weird, the fact that there was a man in the house".

Yesim sees women as the authoritative figure in the household, both "the man and the woman", and this is why she felt "weird" when there was a male figure in the house. Her narrative suggests that women have become stronger and more dominant due to the absence of men. Nil, a homemaker from Serinyol, also sees the good and the bad: 
“Men's labor migration puts double pressure on women, she has to be more aware, has to take on the father role, has to act like a man. In terms of finances it's more comfortable, but she has more weight on her shoulders. The only positive aspect is that there is no domestic violence, no nagging man."

HDP politician Neriman, on the other hand, believes the bad outweighs the good:

"Yes, in a way migrant labor enables women to be more active decision makers, but at the same time it makes life harder for them. It's not only about raising the kids and taking care of the household, but they face great pressure from society. People start questioning women's behavior. For example, if your husband is abroad and you get dressed up, people begin to wonder with whom you are meeting up. Some Alawite women don't care or pretend like they don't care. There is also the issue of sexual needs in the absence of the husband".

Then there are those women who see absolutely no positive side to men's

labor migration. They in fact consider it "one of our biggest wounds". Fidan from

Samandag believes it defeats the purpose of getting married in the first place:

"Our men are overseas and women are left behind and have to be mother, father, everything. This is a serious problem. They say we should be thankful, we get money and can spend it the way we want. But is that it? This is our biggest problem. But the in-laws try to control the woman. More than the religion issue, this is the biggest problem in Hatay, in Samandag. Imagine, the children grow up without a father. My father used to come home for a few days every 20-30 days. My husband came home every four months. Some women see their husbands once a year. I don't think there is anything positive in this. Why does one get married? You want to share emotional things, you want to share everything. Say you have issues with your kids, with whom will you consult? Children have serious psychological issues due to this". 
Then there are cases like Melike's family, where the mother had to take care of her paralyzed in-laws:

"My father went to Saudi Arabia when I was little. It was very hard on my mother, because both of her in-laws became paralyzed around the same time. So, she had to take care of the household, the in-laws and the kids. It was very hard on her. If my father were at home, it wouldn't be so hard on her. He came back after his parents became paralyzed, but still, it's harder on women, they have more to do".

Whether the effects of male labor migration are viewed in a positive or negative light, it is important to acknowledge that there are multiple narratives. Absence of men might be a burden on many women, but it may also be empowering for others. When looking at the issue on a social scale, one might argue that male migration might cause emotional distress on the individual level, but makes women stronger and more resilient on a broader level. 


\section{CHAPTER 6: Arab Alawite Women as Agents of Social and Political Change}

"This type of geopolitical analysis, which is grounded in the everyday of experiences, rewrites women back into this conflict as both mothers and warriors (Dowler, 1998)"- Dowler and Sharp, 2001: 169

Feminist geopolitics has done tremendous work in recognizing resistance techniques of women and other marginalized groups within everyday life. As discussed in detail in Chapter 1, feminist geopolitics puts weight on empirical research and focuses on the often taken-for-granted practices. I find this methodological lens especially useful for this chapter, because of the multi-scalar resistance tactics I encountered among Arab Alawite women. Antakya has been a hotbed of sectarian, ethnic, and political tension since its annexation, and more recently so since the Syrian Conflict. Within this context, how have Arab Alawite women experienced political shifts in Antakya? What kind of a role did they have in these shifts and how did they participate? What new subjects and spaces are produced and how are they racialized, gendered, classed or otherwise power-laden? What sort of implications do these processes have for wider geopolitical shifts in the region? These are some of the questions I answer in this chapter by not only paying attention to the quotidian, but also the more encompassing, grassroots, and regional resistance practices.

Secor writes:

"Despite this attention to everyday practices, feminist analyses should not be seen as exclusively located at the local or micro level. While we have emphasized the ways in which feminist and Foucaultian ideas have retrained 
us to see how politics and power are constituted through the inhabited spaces of our lives, a feminist geopolitics can also be exercised by focusing on global or international relations... In offering a critique of public \pm private dualisms and assumptions about scale and politics, feminist research need not simply replace the global with the local as the 'authoritative' scale of analysis. On the contrary, feminist approaches show how the (imminently political) categories of public and private, global and local, formal and informal, ultimately blur, overlap and collapse into one another in the making of political life" (2001: 193).

In line with Secor's argument that feminist geopolitics involves analysis on multiple scales and not a primary focus on "the micro", I will present my findings on how Arab Alawite women defy cultural, religious and political limitations through daily actions, but also how they organize through feminist and leftist platforms, and forge connections with women across the nation, shifting conversations in the greater Middle East.

Feminist scholarship claims it is impossible to theorize 'the state' as a singular entity. A more productive approach is to analyze the state as "the diverse policies and practices of that wide set of institutions relevant to particular issues" (McDowell, 1999: 172). McDowell argues, "For feminists the important issue is to address the extent to which these institutions act in the interests of men and masculinist power" (1999: 172). I, too, will address certain practices of the Turkish state that marginalize women and the Arab Alawite community. Taking it a step further, I will show how Alawite women are responding to/resisting such marginalization and masculinist power through intimately geopolitical acts (Pain and Staeheli, 2014; Datta, 2016; Faria, 2017) and how their interactions with the 
state are rewriting them as 'active' citizens. This chapter provides an excellent slate for seeing how the state is produced through the body and the complex operations of gendered power across multiple sites, from the classroom to the work place, from the streets to the seat of a pick-up truck (Fincher, in Staeheli et.al., 2004).

I will begin by narrating the stories of four Alawite women, who pushed the boundaries around gender and labor and have established successful businesses in male-dominated work sectors. I will then flesh out the concept of "intimacy geopolitics" by showing how Alawite women are living under and responding to statist oppression and religious double-standards through embodied, every day acts. I will continue to cultivate the discourse on resistance, which is intricately connected to the Alawite collective memory. I will show how this shared history of oppression produces Arab Alawite political subjectivity and adds another layer of resilience to Alawite women. This unique perception of "genetic resilience" provides additional ammunition for Alawite women's political and feminist endeavors at the grassroots. While such feminist endeavors often ascribe to leftist and/or socialist ideology, these women are pushing the envelope further by calling out patriarchal and masculinist practices within such organizations. Querying whether Arab Alawite women feel the need to organize independently, I will end the chapter with a discussion on the prospects for a potential women's movement based on the Arab Alawite identity. 


\section{1. 'Meddling in Men's Business': Arab Alawite Women's Interruption of Masculine Spaces}

Zelda and I follow Nilay out of her apartment and come to a halt in front of a rugged medium-sized truck. As we climb in, Zelda and I assume the truck belongs to Nilay's husband. To our surprise (and gendered assumption) we find out that the truck belongs to Nilay and she uses it for her animal feed business. I am reminded to check my own gender stereotyping. Nilay tells us that she is the first woman to enter the animal feed sector in Antakya. She wears multiple hats; she is a mother, businesswoman, activist, and politician. She recounts how she engaged in strenuous physical labor as part of her business, which required her to lift and carry heavy bags of animal feed, load and unload the truck, etc. People were impressed by her physical strength and used to 'compliment' her by repeating the Turkish saying that she was "a woman like a man". "I hated it when they called me that and corrected them each time by saying, 'I am a woman like a woman'," she says.

The employment sector has been a critical area for Alawite women's struggles for economic independence and personal fulfillment, challenging patriarchal structures, and interrupting masculine spaces. With or without a formal education, Alawite women are opening their own practices, claiming positions of power, and entering male-dominated business sectors. Like Nilay, Amina is also a pioneer as the first woman to enter a male-dominated silk industry. Her motivation was partly rooted in her frustration with her husband's "lack of business-savviness". She explains: 
"I decided to start my own business. I thought we each should run our own business, since my husband didn't listen to me. I started working by myself, but within two years my business grew. I didn't receive any training, I learned everything on my own. I love to research and I read a lot".

It was not easy, however. Existing businesses were not happy with her business endeavor turning into success. She fed off their negative attitudes and let them motivate her:

"People in the silk business, when they saw my success, they stopped giving me silk. They tried to block me. I said I will weave it myself. They said that's very difficult and I wouldn't succeed. With the help of my husband, who grew up in a household with weaving looms, I bought my own loom and started weaving. Where there is a will, there is a way. The more people said I wouldn't succeed, the more I became ambitious".

When I ask why she received such strong backlash, she responds:

"I think the reason why others tried to block me was because they wanted to dominate the sector and didn't want competition. Also, I think they didn't expect a woman to enter such a challenging sector and become successful."

She tells me how the strongholds in the silk business are all men, except for her. Women did not even think of getting into this business, "but once I got into this sector, it opened doors for many women and they started bringing in their wives and daughters to work," she adds.

Halime, who started a nursery and landscaping business, is also the first woman in this sector. Through her business, she did not only challenge gender norms in her society, but also implemented equal pay and positive discrimination in 
favor of women. She describes herself as an environmentalist, a mother, and a former politician, who continues working towards her vision of a more just, more conscious, and more egalitarian society. She proudly tells me:

"I really wanted to produce, so I started my own business. I accomplished a first in Antakya, I created a supply before there was even a demand. I was growing flowers and then fruit saplings. I found out that I had the capacity to supply $10 \%$ of the country's demand, the ministry told me. I always worked with women, I think they are more trustworthy. If a couple worked, the husband couldn't collect the wife's salary. For the first time, seasonal [agricultural] jobs paid equal wage to men and women. In other places men to women ratio is $50 / 30$, something like that. Women always earn less. The supervisors in my business are always women. I am the first female entrepreneur in this sector. My family tried to talk me out of it, but they eventually came around. I sometimes had to drive alone to another city. My husband has respected my work and doesn't intervene".

Halime has a higher education and has been fortunate to have the support of her family, but juggling everything at once has not been easy. "It is not only about entering male-dominated spaces, but to maintain those spaces and remain resilient in the face of patriarchy," she adds. High school vice principal Sevil knows all too well what it means to hold a position of authority and continuously be questioned because she is a woman:

"I am having problems at my workplace as well because I am a woman. Parents want to speak to a male authority. Then they are re-directed to me, because I am the executive power. I think it has to do with the perception that men are more cut-throat and get things done. They associate power and authority with masculinity. For example, men make decisions, but women are expected to implement. For example, the course schedule needs to be organized, but men go to eat, who will make the schedule? I will. Women are expected to do the desk jobs. This is normalized." 
Through these four narratives, we are able to trace the steady footsteps of Alawite women into male-dominated employment sectors, disrupting masculinized spaces. These women are changing gendered work stereotypes in a multitude of ways that are embodied (such as carrying heavy bags of animal feed or wearing garden boots instead of heels to work) and that are transforming working conditions for other women (such as equal pay and becoming part of decisionmaking mechanisms), thus changing the face of authority through everyday acts.

\subsection{Intimacy Geopolitics: Embodied Resistance around Language Politics and Marriage/Divorce}

"Citizenship works not only at the state level to assemble identities and position them variously in relation to discourses of 'belonging' and 'rights,' but also at the scale of everyday, urban life." (Secor, 2004: 353)

Language has been a powerful tool of resistance, particularly within societies that were colonized or are threatened by assimilation (Young, 1990). In the case of Turkey, the Kurdish language has received the strongest and cruelest suppression from the state, making it even illegal and punishable to speak in public until recently (Caglayan, 2008; Ergin, 2012). Arabic has also faced legal and social aversion, but not as strong as Kurdish. As discussed in detail in Chapter 2, after Antakya's annexation, the Turkish state implemented a series of assimilation strategies targeting ethnic minority groups in the region. Arab Alawites were told they were Hittite Turks who had forgotten their mother tongue. The state swiftly sent Turkish teachers to the region to incorporate Turkish into their daily lives. Throughout the 
Republican era, Arabic was banned at times, depending on who was in power (Mertcan, 2014).

Up until recently, Arab Alawite families shied away from teaching their kids Arabic, in fear that their children would speak Turkish with an accent and be ostracized. However, as stated in the earlier chapters, the Syrian Conflict and Gezi protests have revived the Arab Alawite identity and invigorated the Arabic language. Since child rearing falls heavily on the shoulders of women, the 'mother tongue' of the child relies on the mother's choice and efforts. Alawite mothers are increasingly choosing to raise their children with Arabic. Faria recounts in her work how Sudanese women in Diaspora are strengthening their children's ties to their culture through "everyday acts of childcare: speaking regional languages, cooking regional dishes..." (2014: 1057). This act of gendered resistance to dominant culture goes well beyond the private sphere (Cope in Staeheli et.al., 2004). In Antakya, more people are speaking Arabic in public, aware of its negative connotations and potential backlash. Former PWA member Burcu sings in an Arabic choir and ran into a stranger on the bus, who had been to a recital of her choir. The man insisted on paying her bus fare and said, "In the era of AKP, where fascism is rampant, you sang in Arabic and said all those things. That is bravery. I would even pay your rent". Social psychologist Berrin explains how Alawites are just recently getting over the idea that speaking Arabic was anti-progressive:

"People believe that Kemalism equals modernism and that tradition and modernism are binaries. They thought tradition was something to be ashamed of and they used to be ashamed of Arabic. This changed within the 
last 5-10 years, perhaps due to AKP's oppressive politics. The Kurdish movement also had an impact in preserving our mother tongue."

Language politics in Antakya has a long and painful history. Burcu tells me that the cruelest Sunni teachers were sent to Alawite villages and implemented strong rules to prevent Arab children from speaking Arabic. The majority of my interviewees, who were in elementary school up until the 1980s, told me that if children spoke Arabic on school premises, they faced a number of punishments, such as beating of the hand with a ruler, standing on one foot in front of the classroom, taking away their pocket money, etc. Burcu recounts how when she was 6-7 years old, her teacher asked her to name some fruits and vegetables in Turkish. But Burcu did not know any Turkish. Her first word was green beans (fasulye), which luckily for her was the same in Arabic, which she was initially not aware of. Once she realized she had said the correct word, she thought that adding '-ye' to the end of any word would make it sound Turkish. Soon the whole class, including the teacher, were laughing at her. Burcu began crying while telling me this story, how she was so embarrassed and packed up her bag and left the classroom crying, and refused to go back to that classroom. Burcu became a teacher later in her life, but this trauma is so deeply embedded, that it still makes her cry today, even after sixty years. This is the power of social trauma and the result of intimate violence, or intimacy-geopolitics (Pain and Staeheli, 2014). Nurgul, folk music singer from Gumusgoze, describes this act as "the tangible oppression of the state" and underlines the importance of tangible, everyday resistance: 
"The system we are talking about it not that abstract. The system is organized in every cell. When the teacher tells you not to speak Arabic, s/he is expressing the mindset of a system. You then act accordingly. What you learn at school is the ideas of this organized institution. This system is not abstract. That's why we need to engage in more tangible acts. Organization is not abstract either, it begins from your daily life. If you think Arabic is important, you need to find ways to teach your kids Arabic. It all depends on how well you can incorporate these things into your own life. We are talking about organization in all areas of our lives. We need to search for more channels and ways to work together, as Arab Alawites. There are efforts for this and more political organizations on identity, but this is not enough. We always need to look for ways to better ourselves."

Aside from the Arabic revival, which is a resistance tactic against the Turkish state and cultural assimilation, Alawite women are also engaging in strategies that challenge patriarchal and religious codes. One of these strategies is the preservation of the maiden name or the hyphenated last name. Lawyer Yeliz tells me that she is one of the first women in Antakya to use a hyphenated last name and women are increasingly keeping their last names by appealing to the Court of European Human Rights. Feminist and political activist Leyla is one of the first women to keep her maiden name.

Yeliz is divorced, and as part of her legal practice, she takes on divorce cases. She tells me that divorce rates have gone up within the past ten years. From a religious and social standpoint, divorce is frowned upon, but the increasing number of divorces are an indication of not only increased financial and emotional independence of women, but also of their religious and social defiance. The majority divorced women I interviewed told me that life as a divorced woman is not easy. Yeliz did not have much difficulty as a divorced woman, but most women are 
questioned by their extended family about their whereabouts and companions. "You need to be very careful how you act in public; if you get divorced, you become a 'bad woman', and it is more difficult in rural areas than in urban areas," she says. "There are people who get divorced because they are not in love anymore, but the biggest reason is domestic violence," she adds.

Ceren, also a divorced woman and a lawyer, shares her experience:

“When I told my family that I was getting a divorce, they didn't oppose or anything like that. I learned what it meant to be a divorcee, even though I have lots of advantages such as my job etc. Where ever I went, I always was faced with the male hegemonic mentality. They try to establish control over everything; the way you dress, walk, talk, etc. Marriage is like a shield and protects women to a certain extent... Divorced women are seen as 'easy'... I practice family law and take a lot of divorce cases. I haven't met anyone whose expectations were met in a marriage. I still don't see it. People cannot meet each other's expectations, and then it's a disaster... Three times I almost got married, but walked away. I didn't want to express myself as a married woman in my life perhaps. I live by myself in Sumerler ${ }^{89}$. The neighborhood makes a big difference, you know, whether you live in a Sunni or Alevi neighborhood. I never experienced any oppressive attitudes from my neighbors."

When it comes to divorce, class is an important factor. Ceren comes from a middleupper class family in central Antakya, which has relatively eased her experience as a divorcee. Feminist activist and HDP politician Neriman, who comes from a working class family in central Antakya, did not have it as easy as Ceren. She says:

"I just got divorced, ten days ago. I am having serious problems with my family, not my ex-husband. They worry about what others will say. 'You don't have a man anymore, you shouldn't be seen with other men, you shouldn't

${ }^{89}$ Sumerler is a majority Arab Alawite neighborhood in Central Antakya. 
invite men over to your house.' I told them that whoever has entered my house before will continue to enter. Basically, that my life will not change."

As the vice principal of a Samandag high school, Sevil might hold authority in certain spectrums of her life, but as a divorcee she is struggling to dictate her own life. Her family is constantly questioning her whereabouts and her friends are telling her to be more careful after the divorce, that she should be careful when laughing in public. "A female friend told me that my laugh was too loud, just two days before Bulent Arinc ${ }^{90}$ said that women who laugh aloud in public are dishonorable," she tells me with a bewildered facial expression.

Songul is a lawyer, feminist activist and HDP politician, who also takes on divorce cases. Part of her mission is to offer legal and emotional support to women who are undertaking one of the most challenging acts in this society. When she feels the woman needs psychological support, she directs her to a counselor:

"The most common question I get is, 'what would you do if you were in my shoes?' Since I am a feminist, I cannot really empathize with them, because my decisions are a lot more radical and it won't be suitable for them. So, I redirect them to a volunteer psychologist or other psychologists I know. If the client doesn't have financial means, then I can redirect them to the Bar Association."

${ }^{90}$ Bulent Arinc served as the Deputy Prime Minister under AKP government between 2009-2015. During a religious holiday ceremony in July 2014, he said women should not laugh in public. His statement caused an uproar among many segments of the population, especially women and feminist organizations. 
Songul's day-to-day interventions do not only consist of aiding women during this

difficult transition in their life, but also challenging religious leaders on matters pertaining women in the religious order:

"This one time, some sheikhs were facing a lawsuit, because they were giving Quran lessons. They gave me power of attorney and we were discussing the case. At one point, I told them I had a question. I asked them why divorced women cannot take part in religious rituals. I wanted a source, a proof of this. They all looked at each other and couldn't answer my question. This other time we asked Nasreddin Eskiocak, the most renowned sheikh here, for a source where we could learn about Alawite women's rights and regulations, but there is nothing. The sheikhs also don't know."

Songul's endeavors may not always bear fruit, at least in the short term, but she believes her interventions help stir up conversations and mindsets. She is aware that sheikhs cannot always act as individually, but are bound by the religious institution:

"Men have conversations after namaz, where they discuss various topics. I even asked the sheikhs if they could discuss the various burdens on women, how they have equal rights as men, that they have to be both father and mother to their kids, that they work in the fields like men, and that if they have legitimate reasons to get divorced, it is alright. They said 'no'. The sheikhs also have a cast system amongst each other, so if one says something, the others can ostracize him."

Nevertheless, women like Songul are persistent in their interventions and refuse to remain tacit. Over time, they believe things can change for the better, as it is already happening with divorce cases. Birgul, a journalist who comes from a low-income family, thinks that getting divorced has been easier on women more recently: 
"Families used to put a lot of pressure on women who wanted to get divorced. This is a bit better now. Families are actually more worried about the financial aspects, because the woman will take care of the kids. I also felt pressure from outside. 'Divorced' has a negative connotation. But as long as I don't hurt anyone, this is nobody's business."

As a divorcee, Birgul is not only defying religious and cultural codes, but by sharing a house with her ex-husband, she is pushing the boundaries even further:

"I live with my ex, it's actually much better this way, we are like roommates. We have our freedom. We didn't have a bad break up. But of course, others don't approve and they question us. As if we are supposed to be enemies. At the moment, we don't have any problems. We decided to live together until we reach better (financial) conditions."

Alawite women continuously question and challenge religious rules that treat women unequally. For example, divorced women are not to take part in religious rituals, a rule that does not apply to divorced men, but many women insist on taking part in their already limited religious practice. Some women gain the knowledge and courage to defy such religious codes through feminist organizations. Nesrin from Samandag explains:

"They say that we are not supposed to pass by the ziyaret when we are menstruating, but I do. My outlook changed a lot after I went to Women's Solidarity meetings. I pass by ziyarets even when I am menstruating."

Such small acts might be overlooked as they seem mundane or small, but as feminist geopolitics argues, these acts are embodiments of micro level resistance. Feminist scholars view the body as site (Yuval-Davis, 1999; Dowler and Sharp, 2001; Hyndman, 2004; Fluri, 2009; Erickson and Faria, 2011; Clark, 2013), thus, 
intimate acts such as those around menstruation, virginity/impurity, last names, and speaking with an accent, become politically charged and re-scripted as resistance (Cope in Staeheli et.al., 2004).

Pain and Staeheli quote Sharp, "Many talk about minor bodily acts and transgressions becoming expressions of resistance, but of equal importance are questions around when people choose to take the intimate into the public, and under what circumstances" (2014: 357). Similarly, Cope underlines the importance of understanding political actions by questioning the act itself, where it happened, by whom it was acted out, and why:

"...the range of what can be considered a political act is very broad. From telling stories to carrying signs, from purposely slowing down on the job to going on strike, from street theater to letter writing, from non-violent sit-ins to suicide bombs, the scope of possible actions is limited only by the strategies and motivation of the actors. The social construction of gender, however, influences the ways that political acts are performed and how their meanings are interpreted" (in Staeheli et.al., 2004: 74).

The empirical focus on small acts of resistance in this section extends feminist political scholarship on resistance and intimacy geopolitics. It brings in fresh examples from the field on how women are reclaiming their bodies, their names, their speech, and their intimate relationships. This work also complicates our understanding of 'resistance', showing that it is not always 'direct', thus complementing existing work on gendered agency/resistance. At the same time, it illustrates how resistance is often gendered, classed and racialized. 


\section{3. "Resisting is in Our Genes": Practicing Citizenship and the Power of Collective Memory}

This section delves into concepts of belonging, citizenship, and collective memory in showing how Alawite women are reading and challenging the state. Arab Alawites continue to negotiate their "double consciousness" (DuBois, 1903) in a country that has imposed "citizenship from above" (Turner, 1992; quoted in Secor, 2004: 355). “Turkey was a geographical concept, and the Turkish people were (ideally) defined as those living in that territory" (Gulalp, 1995; quoted in Secor, 2004: 355), however "the new state was also and paradoxically constructed to be 'the nation state of the Turks'”' (White, 1999: 80; quoted in Secor, 2004: 355).

Therefore, while Arab Alawites became Turkish citizens after Antakya's annexation in 1939, they have always been 'the Other'. As "multi-layered citizens" (Yuval-Davis, 1999), Arab Alawites continue to struggle for equal citizenship. Feminist and political activist Leyla breaks it down:

"The Turkish-Islamic synthesis is the perspective of almost all government agencies. This is because Turkey isn't run by the government, but by a deep state. This deep state has a specific approach, which is a Turkish-Islamic approach. When I say Islam, I mean the Hanefi sect, which already doesn't accept Alawism and they consider themselves (real) Muslims. They consider Alawism as deviant, even as heathen. That's why Alawism here is othered, excluded. And as you know, Alevis have endured systematic massacres throughout history. Arab Alawites have not experienced direct massacres, such as the Sivas and Maras massacres (in recent history), but we have endured other things. Especially after the annexation of Hatay, the state has implemented assimilation politics and assimilation projects." 
Under the Turkish-Sunni domination, Arab Alawites have faced assimilation that has tried to mold them into the 'ideal Turkish citizen' and they have continuously struggled for cultural survival. While assimilation can happen willingly and organically in some cases, it can also be the result of a forceful approach, which includes forms of domination or even oppression. However, "Integration into the full life of the society should not have to imply assimilation to dominant norms and abandonment of group affiliation and culture (Edley, 1986; cf. McGary, 1983, cited in Young, 1990: 168). Gulsen explains how Alawites have battled with assimilation:

"The Turkish state was somewhat successful in assimilating us, especially in terms of language. But they were only successful in part, because Arabness is still alive, our culture is alive. We haven't forgotten our language in ninety years. This means there is something deeply rooted here. Someone who is Arab Alawite cannot have a place within this state. The state has a religion and a nation. They don't accept the term 'Turkiyelilik' ${ }^{91}$, only 'Turkish', therefore we aren't included in that definition."

This statement reflects a strong sense of exclusion. It also echoes a sense of abandonment by the state, which I have encountered during many conversations. Alawites often lament how they have done their part as citizens and have not caused any problems, "unlike the Kurds92", but still do not 'belong' to this nation. One focus groups participant in Harbiye pointed out:

"We have completed our duties for the state, but has the state completed its duty for us? Us Arab Alawites, have been loyal to our state for our entire

91 “Turkiyeli" means someone from Turkey, 'of Turkey'.

${ }^{92}$ Meaning, Arab Alawites are not trying to establish their own state, unlike some Kurdish nationalist groups do. 
lives. We have always paid our taxes, never created any problems, we always fulfilled our duties for our state. But did the state fulfill its obligations toward us?"

Another participant of the all-female focus group harbored similar sentiments:

"Since there is no assistance from the state, we are taking care of ourselves. There is also great help from overseas, from the male migrant workers... The state has always believed that the reason why Hatay is developing is because we are receiving funds from outside sources. This is not true. Go to 100 homes, will find that 95 of them have family members working abroad. They are hardworking. They work, earn and bring the money here and help with development... The state is asking, "how come Hatay is developing, how come it's so wealthy?' It's because people are working overseas. The state doesn't take care of us, but we still pay our taxes."

Alawite women are transforming this sense of abandonment, or marginalization, by the state into resistance through not only everyday acts (such as those described in the above section), but also through more 'visible' social and political mobilization. They are responding to the exclusionary state practices through empowering themselves and their community. This empowerment manifests itself through increased political and feminist organizations that try to raise the local consciousness, create multi-scalar discussions and demand change, as I will discuss in more detail in the next section. Naciye, a unionist who moved here from Ankara, sees how Alawite women are taking matters into their own hands:

"I didn't know anything about Arab Alawism when I came here. But with time, I came to see that if women put their mind into something, they will fight until they get it. During Gezi protests, women were the majority. They are afraid that the AKP government will take away their rights. They don't want to be stuck back in the house. The republican values have given women equal rights. They didn't have to fight for these rights, but now that they are 
being impinged on, they begin to fight back. The AKP's anti-women politics angered the women here, so they took to the streets. They were right."

The sense of exclusion prevalent among the Arab Alawite community dates far back, and it is often blended into conversations around resistance. Iris Marion Young writes, "Politics... includes all aspects of institutional organization, public action, social practices and habits, cultural meanings insofar as they are potentially subject to collective evaluation and decisionmaking" (1990: 34). This understanding of politics encompasses all spheres of lived experience, the past and the present. When striving to understand the present experience of Arab Alawites, we cannot overlook the past nor how it has shaped the Alawite collective memory. The nonconforming, rebellious nature of Anatolian Alevis and Arab Alawites is often tied back to the injustices Caliph Ali endured. Social psychologist Berrin says of Arab Alawites:

"It's a rebellious culture. It could also be that the collective memory is shaped that way, due to the injustice Caliph Ali has faced. It's been 500 years, but it continues. There have been many Alevi massacres throughout history."

Interestingly, many Alawites believe that resistance is ingrained in their genetic codes, as Amina suggests:

"I really believe that Arab Alawite women have a strong structure genetically, because they have been subject to oppression historically and they had to stay strong. They know how to resist and they know what they want and will fight to get it. They don't give up easily. There are class differences, but still our women are ahead. They had to be strong and this was passed on genetically. Even today, they had to prove themselves to get a job, always had to better themselves. Nothing was offered to them on a platter." 
This interpretation was not only held by Arab Alawite women, but also by Sunni women from Antakya. Former Antakya mayor Pelin, who is Turkish Sunni, has a similar argument:

"Arab Alawites have always had to struggle and resist the system, because they have always been oppressed. This is why Alawite women are one step ahead. And this is what you see when you look, wherever there is a successful woman, she is either Alevi or Kurdish. Perhaps I can't give you statistics on this, but this is what you will find."

Goner's study on Anatolian Alevism has a unique and interesting interpretation of the resistant nature of Alevis in Turkey. While she primarily focuses on Turkish and Kurdish Alevis, her observations are applicable to Arab Alawites. She writes on the intricate connections between religion, inequality, collective memory, and the Left:

"Today, however, most Alevis no longer see religion-at least Alevism in the form of a religion - as 'an opiate', but rather perceive it as a better and superior understanding of 'equality and justice'. In most interviews, Alevis claimed that the compatibility of Alevism and the left comes from the fact that Alevism was the cultural echo of resistance to all kinds of inequality and injustice. Suppression of Alevis and obstacles to their representation throughout history are cited as explanations for the basis of resistance. Therefore, we can argue that the counter-hegemonic tendencies of Alevism come from the non-conformist nature of Alevism as a culture and religion that has an 'elective affinity' (to use Weberian terminology) with nonrepresentation in the hegemonic discourse of the state." (2005: 125).

Goner observes how Alevis attribute their counter-hegemonic tendencies and resisting injustice to their history of oppression since Caliph Ali. This collective 
memory is a powerful one; it tightens the bonds between its members and even acts like a shield. It manifests itself as a picture of Caliph Ali inside a home or a barber shop, as a sword ${ }^{93}$ pendant dangling from a necklace, or as a tattoo that reads 'Ali' in Arabic calligraphy. Religious bonds and shared history are reiterated through such intimate acts, and are carried into the political sphere.

While hinting towards essentialism, the above comments made by Alawite and non-Alawite women regarding "resistance as part of the Alevi genetic code" are indicative of how Alevis/Alawites construct their group identity through their shared history of oppression. This is important to recognize particularly when analyzing identity-based initiatives, organizations, or political parties that cut across class, gender, and religious sect. It is precisely through such collective memory that Arab Alawites practice citizenship in Turkey.

\subsection{Arteries of Antakya: Politicization and Resistance through Grassroots Feminist Organizations}

"We are a handful of women here, but we are the arteries of Antakya, trying to do something." - Burcu, former member of the Progressive Women's Association

Referring to Sharp (1996), Fluri writes, "the gendering of nation and nationalism has historically positioned women as symbolic markers of the nation, rather than as agents and active participants in the political system" (2008: 43).

${ }^{93}$ Caliph Ali's sword, known as Zulfiqar, was a double-edged sword given to him by Prophet Muhammed. Today, the sword symbolizes Ali. 
Theorizing gender and nation, a rich body of feminist scholarship contests the notion that women's primary role within the nation has been to bear future generations (Yuval-Davis, 1996; McDowell, 1999; Staeheli, Kofman \& Peake, 2004).

These scholars have conducted important work in locating agency and resistance, not only among women, but also marginalized groups (Sharp, 2004; Fluri, 2008; Erickson and Faria, 2011). This section is an analysis of Arab Alawite women's social and political mobilization, which is centered around feminist understandings of socialism, and what it means to be a woman in the Middle East, along with coping mechanisms and resistance tactics, which aim to open up spaces for women's empowerment. Issues that carry the most importance for Alawite women are around domestic violence, second-class citizenship, cultural preservation, and war.

Every year the Evvel Temmuz Festival in Samandag organizes panels and workshops on political, cultural, and women's issues. At the 2014 Festival, the women's panel began with an Arabic sketch on domestic violence. Panelists discussed pressing issues such as women's killings and domestic violence. They explained how such social epidemics were backed by the patriarchal state that not only protected men, but also systematically oppressed women. Hediye explains the legal framework that undermine women's liberation:

"People think of violence as an individual phenomenon. They say men are uneducated, women are uneducated, that's why men beat women and that's why women don't stand up to men. This is not true. These are not individual and isolated events. Male violence is backed by the patriarchal state and thus continues systematically... women are painted as dependent, victim, and their identity is erased... as long as this (mindset) exists, women cannot be strengthened. An independent women's identity cannot be created. We know 
that women experience all types of violence within the family and that men and the patriarchal state benefit from this, that's why they oppose any laws that would liberate women."

Participants discussed the Syrian refugee crises and how women and girls are those that suffer the most, being subjected to rape, forced marriage, sex work, and violence. They expressed solidarity with the wives who lost their husbands in the Soma coal mine explosion in 2014. "They will have to remarry or go to their mother's home to survive," said one participant, pointing out how these women are invisible. Women also discussed how men are an extension of the state and that male violence is not individual, but systematic. "Salvation is not individual," they concluded, and highlighted the importance of mobilization. Feminist activist and HDP politician Candan explains why women's organizations and solidarity are crucial for self-actualization:

"We all experience violence, we know it, and see it. I think we need to talk about it over and over again, because the system normalizes it and tells us that this is the way it has always been. And sometimes we don't realize this and go along with it. So, we need to continuously talk about this within women's organizations, to discuss this and comfortably critique each other. I believe that women's struggle everywhere will only be realized through women's organization. I work at the municipality in Mersin and I can tell you that the decisions made for women by the municipality are not that beneficial for women unless they go through or are filtered by women's organizations. The local government tells us that they have opened up a women's sanctuary, for example, and I tell them why do I not know about this? They tell me that they are already taking care of things and it would be better if I don't get involved. This is what the state also wants to do. It wants to take care of women's problems without consulting women. But if I am the one experiencing these problems, I must have a say in this. This is why we need women's organizations." 
When talking about feminist movements in Turkey, geographical location is important. In the case of multicultural Antakya, feminist connections that cut across ethnic and religious boundaries are at the forefront. This is especially pertinent between minority groups. In the case of Arab Alawite women, we also see an element of pan-Arabism and a desire to connect to an 'imaginary' Middle Eastern community. Candan elaborates:

"During the Gezi protests, yes, women were on the streets, but they were on the streets because of the ban on abortion, increase in violence, confinement into the homes. They were on the streets because of their own demands and they showed their true colors. I think the women's efforts in Samandag are very important and valuable and women's solidarity here is exemplary for other provinces. I think there is a lot of attention here in Samandag, Hatay due to the Syrian Conflict, and we need to think of ways to forge connections with women in the Middle East. We need to do more work on how we can alleviate the effects of war and prevent it. First it was Palestine, then Iraq and then other places such as Libya, but since Syria is closer, we are affected more. There was also a war in the East and maybe next year we can invite a woman from Diyarbakir or Hakkari who is involved in the women's struggle there. Or perhaps even a woman from Rojova, Syria. This shows that no matter where, women's struggle is the same and we are in this together."

Women of the Middle East are overwhelmingly associated with war and violence. These themes are also prevalent in Antakya as a border region. Kadin Emegi organized a panel in Samandag, titled "War - Violence - Women" in March 2016, the flyer seen in Figure 6.1. Panelists consisted of lawyers and human rights/feminist activists, who spoke on female Syrian refugees and the need to connect with them. The Syrian refugee issue is a sensitive topic among Antakya's Arab Alawite community, due to the sectarian and political implications of the 
Syrian conflict. Panelists urged the audience to keep an open mind and show solidarity with Syrian women.

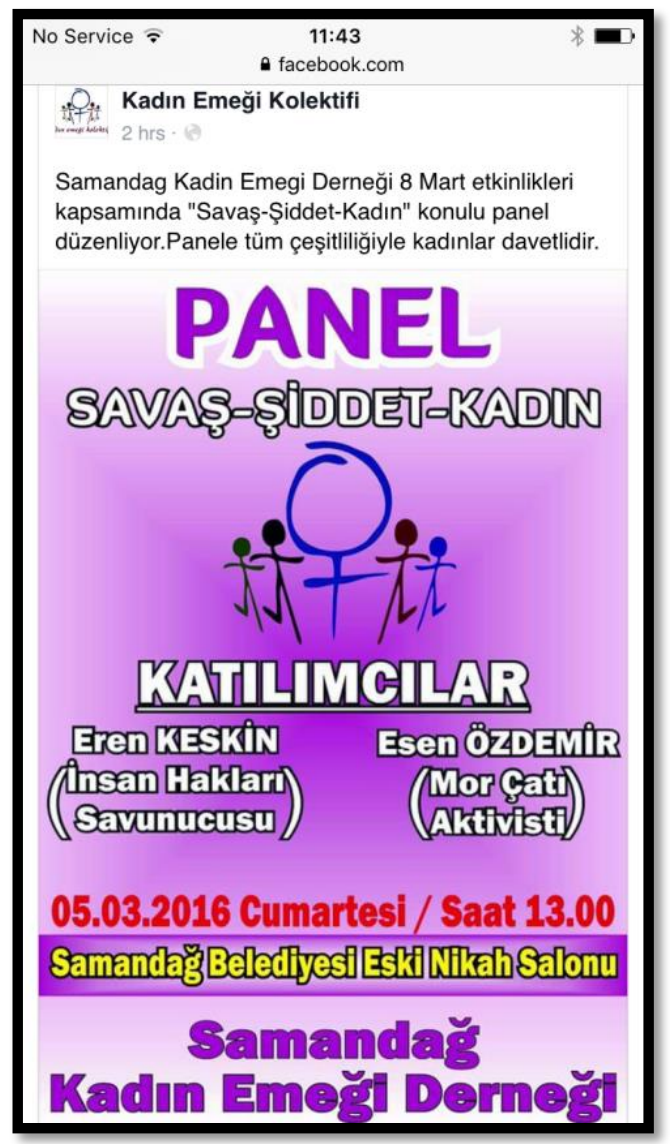

Figure 6.1. Screenshot of the flyer for the "War-Violence-Women" Panel in Samandag.

Women's grassroots efforts in Antakya are multi-faceted. As one of the most prominent organizations, especially among leftist- and socialist-oriented women, Kadin Emegi has several community centers. During one of my visits to the Defne District community center, I listened in the conversations women were having. Their discussions were based on a wide range of topics, such as Arab Alawite identity, CHP and HDP, Ataturk, the Kurdish problem, domestic violence, cultural 
assimilation, Alevi massacres, and Gezi protests. Yet another event I attended was the four-day feminist summer camp organized by Kadin Emegi. I joined one of the workshops titled "Why we need socialist feminism", seen in Figure 6.2. The workshop facilitated discussions on patriarchy and how to recognize it in our daily lives, why we need men as allies, and how socialism alone will not bring about gender equality. Another workshop was built around the importance of women's organizing and how to reach women to join the feminist movement. Figure 6.3 shows the panel titled "We need Feminism for Peace", where participants discussed how war is a masculinist project for economic gains.

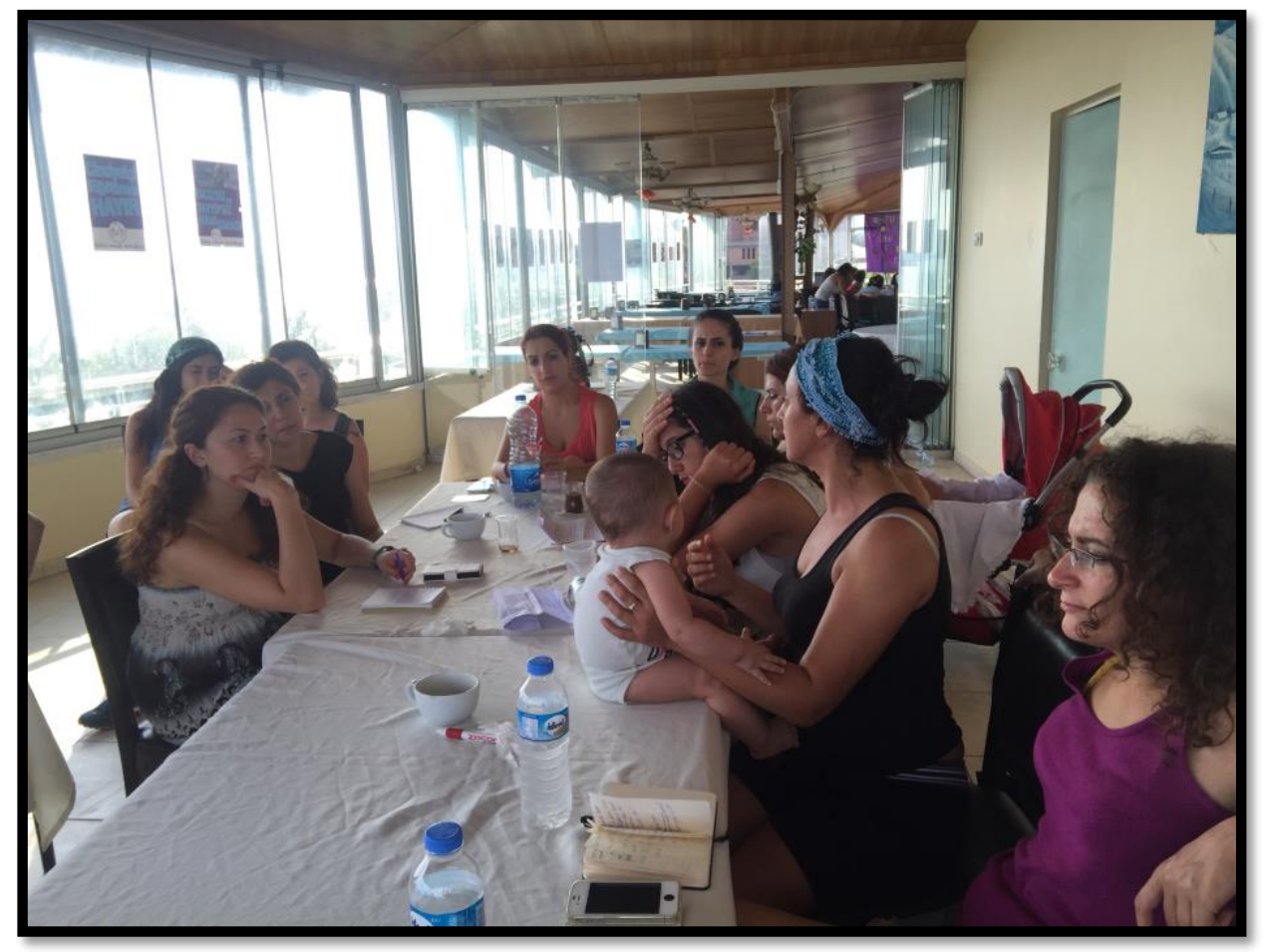

Figure 6.2. Participants of the "Why we need socialist feminism" workshop at the Kadin Emegi Summer Camp, October 3, 2015 
Although Kadin Emegi is widely known and accepted in Antakya today, people were skeptical in the beginning. Lawyer and HDP politician Songul is one of the founders of Kadin Emegi in 2009. She recounts:

"When Kadin Emegi was founded here in Samandag, it was the first women's association, and people were saying that we would make women divorce their husbands. But as people saw our activities and approach, they warmed up to us. After that, there was a women's support center established here. And this is not like being in the women's branch of a political party, where you just host people and serve them tea. Here you are the actor, you express yourself, you educate yourself. When people began seeing how women's education is society's education, they changed their opinion of us."

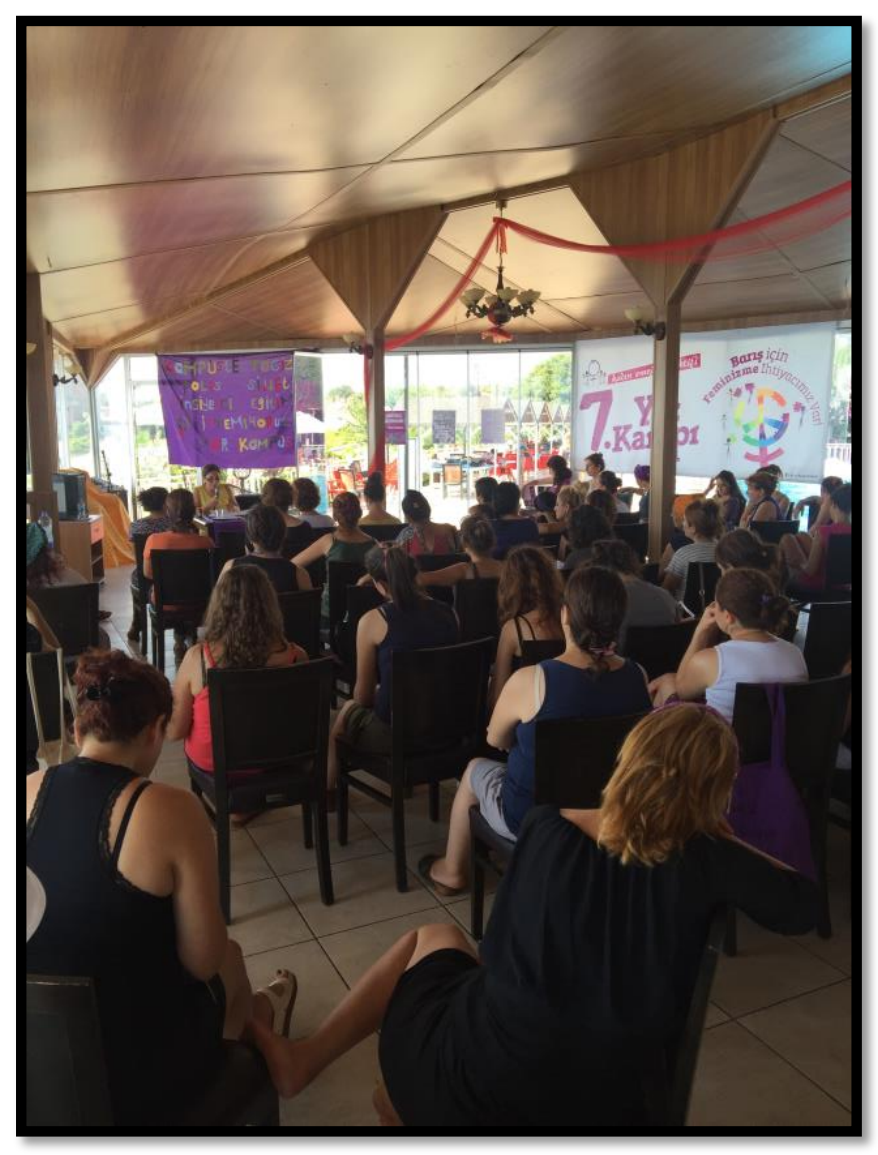

Figure 6.3. "We need feminism for peace" panel at the Kadin Emegi Summer Camp, October 5, 2015 
Journalist Birgul is one of the founders of Defne Kultur Sanat Evi, which is a cultural association with activities such as chess and music lessons, Arabic language courses, painting activities, and a series of women's workshops on women's issues. All activities are free of charge and the association is run by volunteers. Birgul is aware of the responsibility that falls on her shoulders, and on the shoulders of all women who are active and present in the public sphere:

"As Arab Alawite women, especially as women who are more active in the public sphere, we need to organize more activities to reach women at home. We try to do this as an association, but it's difficult. If women don't raise their voice, all these negative things... nothing will change. Women need to be more included in all aspects of life. This is not a Sunni or Alevi problem, this goes for all women. We are very weak in this matter, including me. We need to spend more time on reaching out to women. If we reached one woman a week, that would mean 52 women in a year. If each of these women reached one woman each... we advocate this, but we don't put enough effort into it."

I was fortunate to meet some of the women who were putting in the effort to reach others and pull them into the circle, hence disrupting patriarchal practices within their circle of family and friends. One of the strongest examples I found was within a family of four girls and two boys in Turfanda, a rural village an hour outside of central Antakya. During the olive harvest season, I spent a few days with the family helping out in the olive groves. Grateful for their hospitality and willingness to share a glimpse of their life, I left with a deep admiration and respect for these four girls. I had met Saime and Selime, the two youngest daughters in their early twenties, at the feminism summer camp. As veterans of Kadin Emegi, they had brought along their 19-year-old sister-in-law. Their goal was to "femini-tize" their 
sister-in-law, despite their brother's discontent. Saime tells me how the roots of her feminist consciousness began to form during high school, when her father had rented an apartment in the city center for the children, so that they could go to a better high school. Her brother had expected the girls to serve him and take care of the household, because they were girls. One day, when her brother wanted her to wash his clothes, she rebelled. "I am a student, so are you and you have two hands," Saime told her brother, "I don't have to do anything for you just because I am a girl". He eventually had to accept and learn to tend to his own needs.

For being single in their twenties, the girls face considerable pressure from society to marry, but they are not fazed by it. All four went to college, are politically active, and remain determined to create their own fate. Over a raki and meze spread one evening, without any men present, the girls showed me photos from their brother's wedding, all the while rolling their eyes about how they had to wear makeup, get their hair done, and wear heels. They did not take pride in performing femininity. They are thankful to Kadin Emegi for cultivating their feminist consciousness. Saime, for example, found Amargi through a friend in 2007 and started going to the meetings, film screenings, and gender seminars. She began to question gender roles. When her mother told her that she had to do the housework as a woman, she replied, "do you need a uterus to cook?"

Saime believes that women's struggle is a long-term struggle and the leftist movement alone will not save women. She says: 
"Part of the women's struggle is to engage with those around you and help them transform. If you cannot communicate with them, what good does it do? You say 'feminism', but how much of it do you do in practice? We need to be able to reach women in the household, like my mother, in a language they can understand. If I can change one woman's perspective, I'd be happy."

She tells me how she took her mother to a Kadin Emegi breakfast and her mother was so impressed that she exclaimed, “why aren't all women here?” Even so, their parents are not very happy about the girls' deep involvement in politics. For example, their parents are unaware that their eldest sister was at the Walk for Peace in Ankara, where over a hundred peace protestors were killed by twin suicide bombings. Selime was recently taken into custody during a protest and her wrists are still sore, which proves to be a challenge while making the annual pomegranate syrup for the household. "But I cannot tell me mom," she says. I leave Turfanda with bags full of homemade pickles, olives, pomegranates, raki, and my head spinning from all the stories. I am touched by the resilience of these girls.

Another woman I met at the Kadin Emegi summer camp is Nur. Originally from Mersin, Nur came to Antakya when she got married at twenty-two. Now forty years old and with three kids, she identifies as a feminist. Nur is an elementary school graduate and works as a housekeeper for the SYKP Antakya office. She explains how she got involved with Kadin Emegi and SYKP:

“I am in SYKP and Kadin Emegi. I didn't always used to be political. I politicized after coming to Hatay, after seeing the ambition of women. By seeing them, observing them. I met Filiz when I first came to Hatay through my husband. I saw her ambition and her freedom. First I was at Kadin Emegi and then [through other women] I came to SYKP. At first I was a bit shy 
during the protests, my husband used to be active in politics and they had thrown rocks at his window. That's why I was a bit nervous at first, due to my surroundings, that's why I was reluctant to go to protests. My husband got mad at CHP and joined DYP, that's when they threw rocks at his window. Now he's with HDP. He watches the news with the kids and discusses HDP with them."

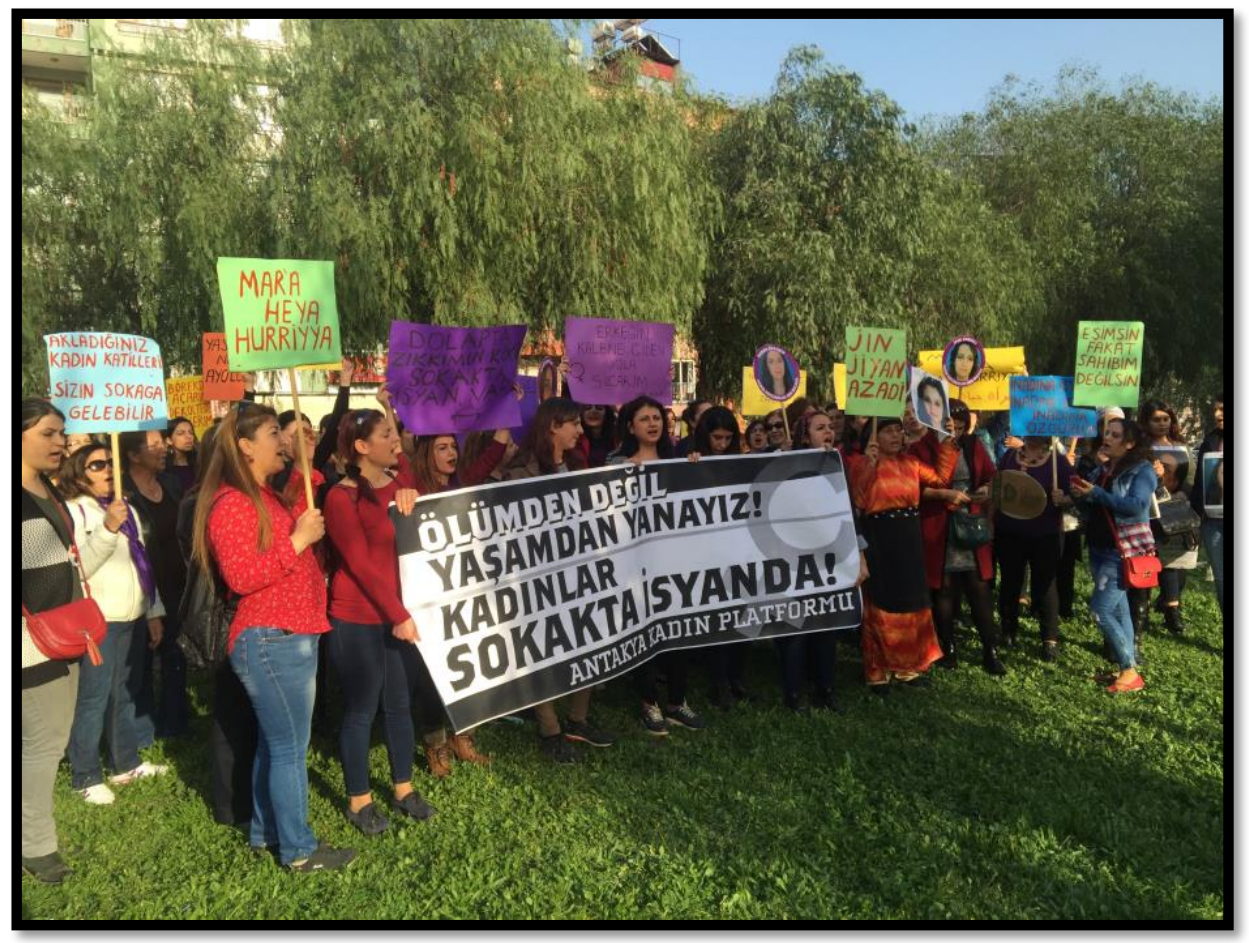

Figure 6.4. Women's March on International Women's Day (March 8, 2016)

Nur is an example of how the feminist movement in Antakya reaches women from different backgrounds, through a multitude of public events and walks, such as the Women's March on International Women's Day. Figure 6.4 shows the Women's March on March 8, 2016, while Figure 6.5 shows various women's organizations protesting violence against women. Although Nur is Arab Alawite, she grew up in Mersin, where the Arab Alawite identity is not as strong and women not as active. 
Still, she appreciates growing up in a mixed cultural setting and is grateful to be part of an organization:

"I have good relations with all cultural backgrounds, since I am used to it from Mersin. During the feminist camp, we don't discuss ethnicity or religion, the mutual topic is women and the political climate... I think being in an organization is very important. On your own, you cannot do anything, you cannot make your voice heard. When you are in an organization, you can make your voice heard, you feel stronger. You become braver. It's different. You don't feel alone."

Naciye took advantage of her husband's status as mayor of Yesilpinar from 1994-2000 and ran the municipality's culture, arts, and women's events. She used the platform to organize women's panels, initiate handcraft courses, but she says that women wanted to acquire skills that would generate greater income. "So, we started an entrepreneurship training," she tells me. Many of these women are now business owners and employ 3-4 women each. Another project Naciye implemented is the Yesilpinar Women's Social Help and Support Association, for which the municipality donated a parcel of land in 2012. Through fundraising, the association funded eighteen women, who became organic farmers. The association only accepts widowed or impoverished women as members.

Aside from the multitude of complications that stem from their ethnoreligious identity, Arab Alawite women are fearful living in the AKP era. The increased conservative approach towards women under the AKP government is making women feel uneasy, especially in Alevi communities, since these women live in a relatively free and open society. Women in the Harbiye focus group were 
tempted to ask for my opinion, as an academic and researcher. “Do you think AKP's pressure on women will increase? Is the situation going to get worse?" I was asked by anxious women.

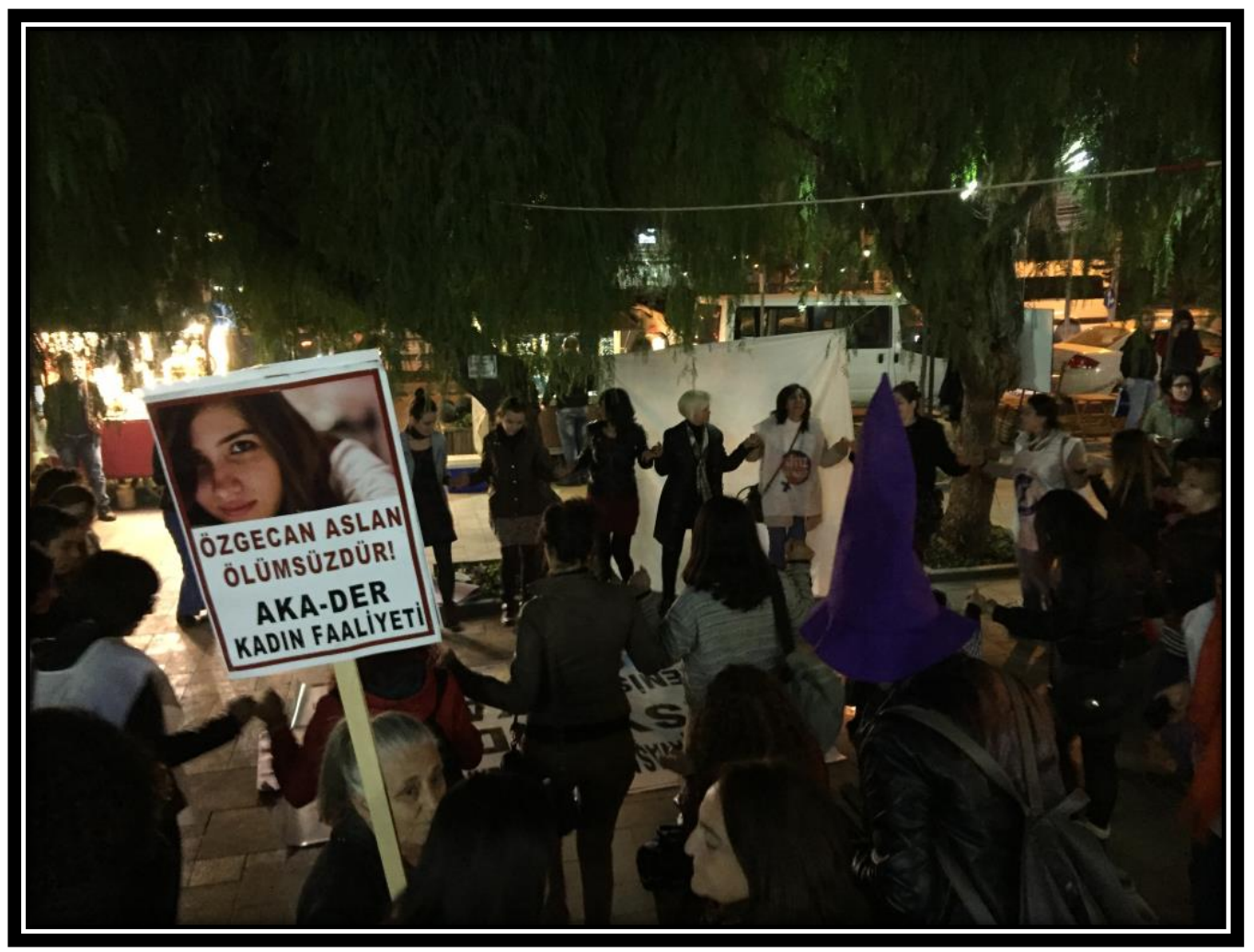

Figure 6.5. Various leftist women's organizations in Antakya protesting together at the "Raise your Voice against Violence against women" event, November 25, 2015

At the Samandag Women's Panel women discussed how even though every government has had a patriarchal political agenda for women, AKP has been the most anti-woman. Lawyer and Kadin Emegi activist Hediye was one of the panelists and she explained what it means to be a woman in the AKP era:

"As you know, most municipalities are under the control of AKP and they really do not offer programs that empower women socially and economically. But what you're doing is great, you are approaching it with a feminist 
viewpoint and offering these women psychological support. You've made a great connection, but unfortunately most local governments in Turkey do not work this way... Another point I want to make is, in every part of Turkey there are different women's movements, due to the region. But there is no such thing as the West is liberated, but the East is not. As women, our problems are the same. In Kurdish regions there is also the problem of violence, also in the Aegean and here, but here you have different problems due to be Arab Alawite women, which you have to voice. In the Kurdish region, due to the independence struggles and identity struggle, it is true that women are at the forefront and this should be an example to women in other provinces. Their experiences in local governance has been an example for whole Turkey. The women's liberation movement was fed by the feminists after 1980, socialist feminist constituents, and Kurdish women's liberation movement. When we say 'women's movement', we mean the combination of all these different movements. We are feeding off each other and must continue to do so. As the sign behind me says, we all agree on the slogan 'do not touch my body, my labor, my identity'."

Panels like this are important sites for the growth and spreading of feminist ideology and action. Women who participate, while Alawite majority, come from various socio-economic backgrounds and are exposed to feminist thought and learn how to frame women's issues. They connect with other women and realize they are not alone. They learn to make demands; to demand more from their lives, from their community and from the state. This panel in particular, organized by Kadin Emegi, used the meeting as an opportunity to make demands to the state, on behalf of women around the country. Hediye ended her speech with a list of demands:

"I would like to end with a list of demands. We want feminist organizations, women's organizations to be included in the court hearings for women's killings. Emotional and psychological violence is as common as physical violence. We need to have hotlines for women to call and share their experiences. Municipalities and women's organizations should have consultancy centers where they offer free psychological support. We need crisis centers where women who were raped or assaulted can go and talk without being judged. We need specialized staff to talk to girls who were 
sexually assaulted and subjected to incest. We need trainings in elementary school to talk to kids about gender and violence. The state needs to include any attacks towards the LGBT community under the crime law. We need to increase the discussions and trainings about homophobia. We want equal pay for equal jobs."

It is important to note that the feminist language used in these circles is often influenced by feminist ideology that is produced in the West. In fact, Kadin Emegi is actively creating reading lists consisting of Arab and Turkish feminist thinkers. Still, this does not indicate the inauthenticity of feminist knowledge circulated in the local circles. On the contrary, hybrid feminist ideologies are produced as a result of blending indigenous practices with Western understandings. For example, Western feminists often talk about religion as a tool to oppress women. While many Alawite women would agree with this statement to a certain extent, they do not abandon religious ideology and traditions altogether. Instead, they continue sending their sons to undergo religious training, because they consider it necessary for cultural preservation. In this regard, Alawite women are using religion as a tool of resistance.

In the light of the recent theoretical debates, I ask Leyla, "do we still need feminism?" She responds:

"I think feminism just began. When you were telling me about this, it reminded me of the discussions about Marxism and how it's over. But the economic crisis of 2008 proved this wrong. They said Marxism is dead, but this was proved wrong." 
Leyla's response is political, as she knows what is at stake not only for women, but for all citizens in the AKP era. Increased pressures on civil liberties, the justice system's reluctance on punishing men who assault or kill women, and growing Sunni conservatism in social and political spheres are alarming. Leyla is relying on socialist feminism to resist the state and masculinist practices and to liberate women. For Arab Alawite women, the meaning of 'liberation' is multifaceted. First and foremost, it means collective liberation as women of Turkey. This entails the closing of the gender gap in all spheres of life, ending domestic violence, retaking control over their bodies, and having the freedom of expression that is not regulated by Islam or patriarchy. Secondly, liberation alludes to a more integrative practice of Islam, namely one that recognizes Alawism, and other Islamic sects, as an interpretation of Islam, without calling it 'deviant'. Lastly, liberation indicates a Middle East free from imperialist powers. In their eyes, this would help end conflicts that they deem as serving Western interests in the region. While Leyla works in leftist and socialist circles in trying to realize these goals for liberation, she is aware of their shortcomings, which I discuss in the following section.

\subsection{Birds Cannot Fly without both Wings: Feminist Critiques of the Left}

"The leftist movement and women's movement are intertwined. Women are one of the wings, and we all know a bird can't fly without both wings. In the struggle against the system, within the leftist movement, women objected, 'what are you trying to do without us?'." - Nilay 
Women in leftist and socialist organizations in the 1970s and 80s had learned a valuable lesson, which is that women need a separate space to organize and empower themselves. Ozcurumez writes that feminist activists of the 1980s “criticized the PWA among other leftist women's organizations for subordinating women's issues to the cause of socialism and the labor movement" (2011: 24). As I explained in detail in Chapter 4, women such as Burcu, Naciye, and Nuray were in constant negotiation with themselves and others about women's rights and socialist teachings. During their time, it was almost impossible to critique socialism and communism from a feminist standpoint. But the following generation of women formed a women's initiative out of the Left, along with the feminists from the 1970s and 80s. Leyla is one of the newer generation feminists, who has dedicated her life to a socialist feminist vision:

"Even though I continue working in mixed socialist organizations, I believe there must be a separate/independent women's movement and have been working for an independent women's organization with fellow women friends for the past 15 years. Under Pinar Selek's leadership, we started Amargi and I am one of the founders. We had a branch in Istanbul, but other than that it was a Southern project. We had two main activities; raising consciousness through readings, panels and workshops, and offering legal and psychological services. We were the first organization to do such kind of work in Hatay, because in the local government system, there are no consultation centers for women, even though there should be [in the 2000s]. We were active for 6 years and then with this group of women we've got, we founded the Kadin Emegi Collective. We transformed Amargi into Kadin Emegi. We still have the same activities." 
Leyla identifies as a socialist feminist and describes it as a "world-view from an economic perspective, one that strives for men and women's economic equality". She argues that women's problems will not be solved by socialism alone:

"I think the economic justice in socialism is important, but I don't believe that once socialism comes to a country, women's problems will be solved. That's why I am at the same time a feminist. I think both efforts must be made, but I think feminism needs to seep into all social domains as a perspective and a lifestyle. I think we should be able to feminize our own socialism."

Filiz is also part of the feminist initiative out of the Left. A group of women within the leftist movement were bothered by the male/female inequality and formed a branch called "The Women's Initiative". The initiative started the journal Amargi, which eventually transformed into Kadin Emegi. Filiz runs the Defne Kadin Emegi branch and tells me that the center attracts women through craftwork and gradually politicizes them. This politicization happens on both levels; feminist and leftist/socialist. Women are taught that without a feminist understanding, the leftist movement will not bring gender equality. While women enjoy the benefits of the center, such as free health services, family counseling, psychological support, workshops and movie screenings, a critical feminist political consciousness is being cultivated.

As the previous head of the Women's Branch of CHP in the Defne district, Nazan has first-hand experience of rampant masculinism within the Left. She points out how despite the supposed social-democratic vision of the region, which claims 
to embrace gender equality, the candidates who run for office are overwhelmingly

male. She laments:

"This area is leftist/socialist, but still under male hegemony. To become successful as a woman... men don't like this. So, if as a woman you are successful, you become a threat, so they try to limit you, block you. They try to put you in a mold. If you are being productive, they don't want you to think independently, they want you to be connected to someone. If you try to do this for the people, you are expected to do this in the name of someone. And that someone is usually male."

Devrim identifies as a socialist feminist, even though he believes men can never be "whole feminists" because they will never be able to experience what it means to be a woman. This does not deter him. He is against a system where capitalism and patriarchy are hand in hand. He is aware that a socialist revolution is not a magic wand that will save women. "We, as men, need to face our masculinity and check our privileges," he says. For this, he believes feminism workshops should hold space for men as well, so that they can be educated. He even goes as far as suggesting masculinity workshops, where men learn how to recognize male privilege and how to overcome it through daily interventions.

Women continue to face gender-based discrimination within a multitude of environments, and class-based movements are no exception. It is commendable that women in Turkey had the courage to challenge masculinist practices in Turkey during the bloody clashing between Rightists and Leftists in the 1970s. Women, too, were beaten, killed, imprisoned and blacklisted, in addition to being raped, as the government began cracking down on leftist organizations. They wanted to be 
recognized for their sacrifices, their contributions, and struggles just as much men were, and to be treated as equals. In Antakya, Alawite women took the lead in intervening in the masculinist spaces within leftist organizations, hence pulling women's political subjectivity to the forefront.

\subsection{An Arab Alawite Women's Movement?}

Chandra Mohanty defines solidarity as "mutuality, accountability, and the recognition of common interests as the basis for relationships among diverse communities" (2003: 7). In Antakya ethnicity, religion, class and geography diversify women's experiences. Taking women as a group of analysis, such as "Turkish women", or "women of Turkey", or "women of Antakya" is problematic, because "it assumes an ahistorical, universal unity between women based on a generalized notion of their subordination" (Mohanty, 2003: 31). We cannot bypass ethnic, religious, social, and political identities. By the same token, it is not possible to describe Arab Alawite women's experience in a homogenous way. Being born into a sheikh family, being born in a rural village or city, having religious or atheist parent(s), growing up in an Alawite or mixed neighborhood, political consciousness, class, and so many more factors shape and alter Arab Alawite women's experiences. Therefore, when I asked Alawite women if they found it necessary to have an Arab Alawite women's movement, their answers varied.

The first time I encountered talks of a separate movement based on Arab Alawite identity within a feminist platform was at the 2014 Evvel Temmuz 
Feminism Panel. "We need to voice the different problems we face for being Arab Alawite women," said one of the panelists. Another panelist explained why overwhelmingly Arab Alawite women were politicizing in the region: "It has to do with minority psychology and also with Hatay's positioning in Turkey; because of the connection and proximity with Syria, when you live here, you are in the midst of political events". These events and the history of the region fuel Alawite women's social and political mobilization. But a separate Arab Alawite women's movement? Was that necessary?

When I interviewed Leyla in July 2014, she had already been thinking about this topic for a few years. She attributed her desire for a potential Arab Alawite women's movement to their ties to the Middle East:

"When looking at it from a broad perspective as Turkey... I am more of an activist who feels close to the Middle East... and I am talking for all of Turkey when I say this, turning our face to the West as the women's movement means that they didn't understand the women's movement in Turkey and couldn't overcome the problems associated with that. That's why we, as the Kadin Emegi Kolektifi, investigate women's movement in the Middle East, read more heavily books from Middle Eastern, feminist authors, this is important to us. I think since the 'Arab Spring' in 2011, some feminists began turning to the Middle East. But I don't think they have yet been able to appropriate the Middle Eastern woman model to Turkey. We are discussing whether or not there should be a separate women's movement for Arab Alawites, but we haven't reached a conclusion yet. We are discussing how it would be, if it's necessary. Personally, I don't think it's very pressing at the moment. Whether or not this is a need, that would be a whole study area on its own."

At the Arab Alawism and Women workshop in November 2015, participants discussed the possibility of such movement. Nazife, who lives and works in Ankara 
and is active in the Arab Alawite Youth Council, said she saw the need for a separate organization, "because we have a different set of problems due to our different experiences". Nazife pointed out how the Syrian Conflict initiated an identity search among the Arab Alawite youth, and as a result various Arab Alawite youth organizations and the Arab Alawite Women's Council (AAWC) was established. “The council is trying to amplify women's voices and it is a result of efforts to raise feminist awareness within the Ehlen magazine," Nazife explained. Women within the Arab Alawite Youth Council did not want the council to continue as a patriarchal structure. AAWC had been looking up to the Kurdish women's movement as an example and for the first time expressed themselves in Arabic on various political and women's platforms. Figure 6.6, 6.7, and 6.8 are photos of AAWC members partaking in demonstrations with Arabic and Turkish banners.

When I interviewed Nazife in Ankara in June 2016, she gave me the entire background story on the establishment of the women's council, which sprang out of the youth council consisting of Arab Alawite university students. The Youth Council came to life after the Syrian War and formed the Ehlen publication. After a while some women within the council expressed their desire to have a women's group, which would also put together a publication about women of Antakya. These women wanted to organize protests for honor killings and read and discuss books written by female Middle Eastern authors. Nazife expands:

“The Women's Council felt the need to found a separate group, because they had difficulty expressing themselves within the Youth Council, they felt the need to support some issues. There is some male dominance within the 
Youth Council. They also felt the need for women's voices on issues like the Syrian war. It's mainly Antiochian Arab Alawite women. We also had nonArab Alawite women who came to observe our meetings and events. It's not so closed [to other women]. I understand how women feel the need to come together to fight against male dominance within the Youth Council. Women who come together feel stronger. Of course, not all women were on the same page, we were different in some respects."

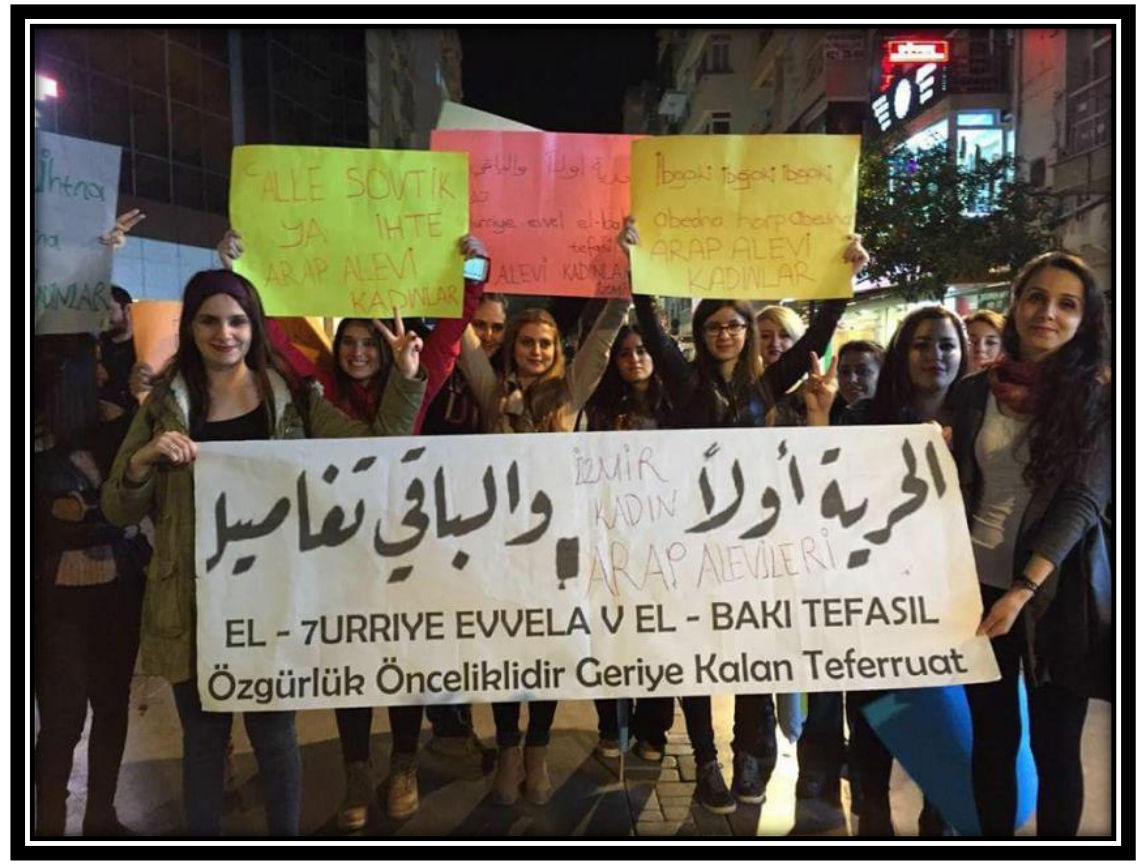

Figure 6.6. Arab Alawite Women's Council, Izmir branch, demonstrating on International Women's Day with banners in Arabic and Turkish, March 8, 2016 (Courtesy of the Arab Alawite Women's Council)

Nazife has been in socialist and feminist circles since she was in high school. She met Leyla and had a conversation with her about women's movements. She remembers Leyla saying, "we are in this struggle, but as women we are kept in the background, we need to organize, raise our awareness and fight back". Nazife was a bit confused by this statement, but her upbringing was very suitable for cultivating a 
feminist ideology. She comes from a family of five girls. People felt bad for her family, because there were no boys. She recounts:

“People said we couldn't inherit, or told my dad why would he educate five girls. But our parents wanted us to study, so we did. So, as girls we were already oppressed. That's why when I found myself in an environment where women were being empowered, I was drawn to it. But my family wasn't happy with me getting involved and tried to make me feel bad, saying, 'your family is trying so hard to send you to school'. My sister and I were taking the entrance exam together and my uncles said, 'if you are successful, you'll be pioneers for so many girls'. Really, people in our community were awaiting our results to decide whether or not it's worth sending their girls to school. So, there was this pressure on us. Therefore, I decided to focus on that and distanced myself a little from politics. When I went to the university, I felt so good and relieved. But then something happened, someone sad something nasty about me chewing gum, so I thought to myself, 'I came to university and I am still trying to be controlled as a woman'."

Around that time, she met Devrim and a few other students from Antakya who had formed a working group. They encouraged her to read and discuss women's issues. In 2008, following the dissolving of Amargi, there was a women's meeting in Antakya and Kadin Emegi was founded. Women from all over the country organized and came together. Nazife did not quite understand at that time and thought to herself, "why do we have to organize separately, when we already have an organization?" But the women were adamant on having an independent women's working group, and with time Nazife understood why.

After graduating from university in the Aegean city of Denizli, Nazife focused primarily on Kadin Emegi. While she was in Denizli, they began organizing protests and even organized a women's conference. "At that time, it was very dynamic," she 
says, "with socialist movements, you have long term goals, but with women's movements, it was a daily fight, it affected our daily lives". Nazife is currently in the executive group for SYKP in Ankara and in the coordination committee for Kadin Emegi. Unfortunately, after the recent bombings people have become scared and activities have slowed down across the country. People are scared to go to protests. Instead of growing, organizations are trying to maintain their numbers.

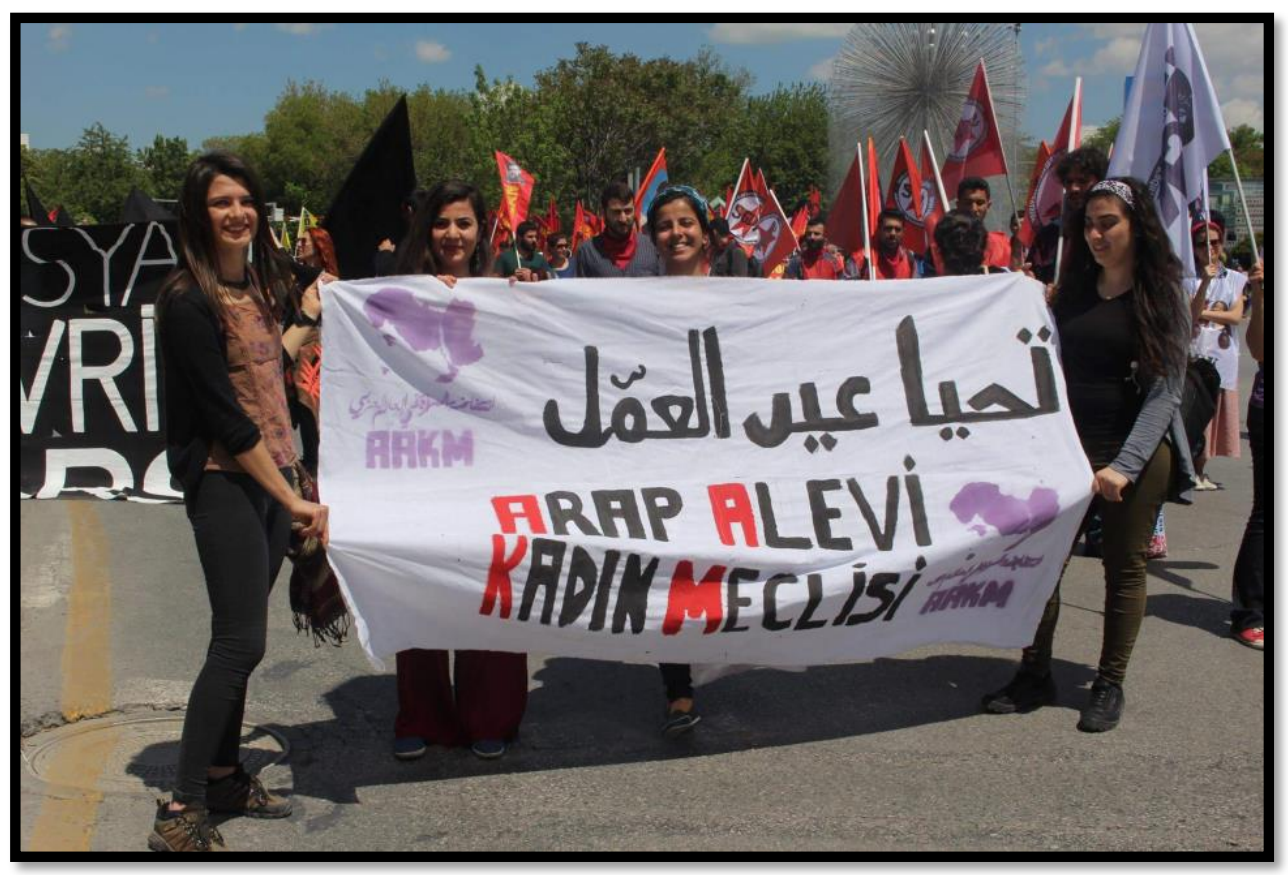

Figure 6.7. Arab Alawite Women's Council demonstrating on May Day in Ankara, May 1, 2016 (Courtesy of the Arab Alawite Women's Council)

Similarly to Leyla, Nazife also draws on the ties to women and feminist movements in the Middle East. She underlines the shared experiences that stem from certain Islamic pressures on women, body politics, and living in conflict zones: 
"Feminist movements have different agendas depending on where they are. The issues Western feminists fight for can be different from ours. I'm not saying one is ahead of the other, they are just different. As women living in the Middle East, we are always faced with war or daily struggles pertaining clothing and our body, abortion, or the rising religious pressures on our daily lives. So, we need to talk about this stuff. Abortion may also be on the agenda of the women in the West, as some backward ideals within Christianity may be against it. But we are also dealing with war and refugees on the other hand. There are so many issues regarding Syrian refugee women here. The war is in such proximity in Antakya, people need to be aware and organized. So, do we feel closer to Middle Eastern women's movements? Due to share experiences, yes. We have common problems with women in Egypt, for example".

Nazife tells me that since the Syrian War, Arab Alawites want to go back to their roots and embrace their cultural identity. Due to increased activity in Antakya, external forces want to intervene and various strands of Muslims flock to the area to Sunnify Alawites. She points out religious leaders within the Arab Alawite community who try to keep women in the background, such as Sheikh Mehmet Guven. She concludes:

"So, there is this danger awaiting us. Yes, we will embrace our Arab Alawite identity, but where will women be in such a movement? Will they be in the background, in the kitchen, or will they be in the frontlines? And we are in a relatively better condition than other women in the region, we are more socially active, we can dress more open, hang out with men, we are side to side with men in weddings, funerals etc. Of course there are troubling gender aspects as well. We are more comfortable in some cases. And we cannot afford to lose this. Organizing is not always for more freedom, sometimes it can bring you backwards. This is why Arab Alawites women need to be alert and organized. All our efforts for women to have a voice is actually based on this very premise".

Lawyer and human rights advocate Yeliz also thinks Arab Alawite women's organization has become necessary since the Syrian Conflict and the heightened 
sectarian language of the AKP government. While she believes that within feminist movements identity should not be important, in the face of growing discrimination against Arab Alawite women makes a case for a separate women's organization. Social psychologist Berrin agrees that political organizations should turn to their own culture, which implies that Alawite women should also build solidarity from within. Lawyer and HDP politician Songul believes that a potential Arab Alawite women's movement needs to be on a cultural basis or could exist as a separate branch within an existing women's organization. Her argument is based on the fact that she does not identify with her given religion:

“Regarding Arab Alawite women's organization... I am a faithless woman, I don't feel very Alawite, not like I belong to that religion. But this would have been the same if I were born into a Sunni family, I would not associate myself with that sect, as I am faithless and don't abide by any religious rituals. But I think there could be an organization in order to learn about and preserve the culture and religion. But it shouldn't be based on being a believer or not. What could be done is if Arab Alawite women can express the problems they face due to being Arab Alawite women, within women's organizations. So not in terms of a separate Arab Alawite women's organizations, as I don't think it is productive to have an organization just based on ethnicity or religious rituals. I feel more inclined towards women's organizations that bring together women of all ethnic and religious backgrounds and are dealing with issues that stem from being a woman. I think that we should definitely try to find solutions to problems and oppressions we face due to being in an ethnic or religious minority, within a women's organizational framework".

Gulizar does not see the necessity for a separate Arab Alawite women's movement. "We share the same problems with other women, regardless of ethnicity or religion. We regard our feminism to be colorful and see this as richness," she says. 
Selda argues that success comes from reaching women of all ethnic and religious backgrounds. She says,

"If I can't reach other women, I'm not successful. If I'm liberated and I'm on the streets on March 8th with other Arab Alawite women, but Sunni women are looking at us from the sidelines and feel left out, and don't feel a part of the movement, it's not enough. Of course, I'm not minimizing what we have accomplished so far, but only then can the women's movement advance."

Whether or not Alawite women feel it is time to organize and express themselves around their ethno-religious identity, they are reclaiming Arabness and reconstructing their Arab Alawite identity. They are active participants in the political and social shifts in Antakya, in Turkey, and the Middle East through their feminist and political activism. Their role in transforming the politico-social landscapes are multifaceted and are executed through both intimate and deliberate acts. Their experience is marked by gender, class, ethnicity, religion and nationalism. This means that their political subjectivity is multi-layered (YuvalDavis, 1999) and influenced by their shared history of oppression, their roles as mothers and wives, their religious 'otherness', and their mother tongue. They continuously contest being "the ground on which discourses of morality and nationalism are written" (Mohanty, 2003: 133). And they encourage each other to seek "unlikely coalitions" in achieving women's solidarity (Mohanty, 2003: 125).

Through their gendered political acts, Alawite women continue to blur the lines between private and public, thus reframing 'the political' in Antakya. Their daily interventions through embodied acts are not only challenging patriarchy 
within their communities, but also within the nation, as seen with the example of language politics. They also find strength and support through leftist and feminist organization, which they highly revere. By looking to the Middle East and forging connections with the women in the wider region, they are kindling a vision of women's solidarity transnationally.

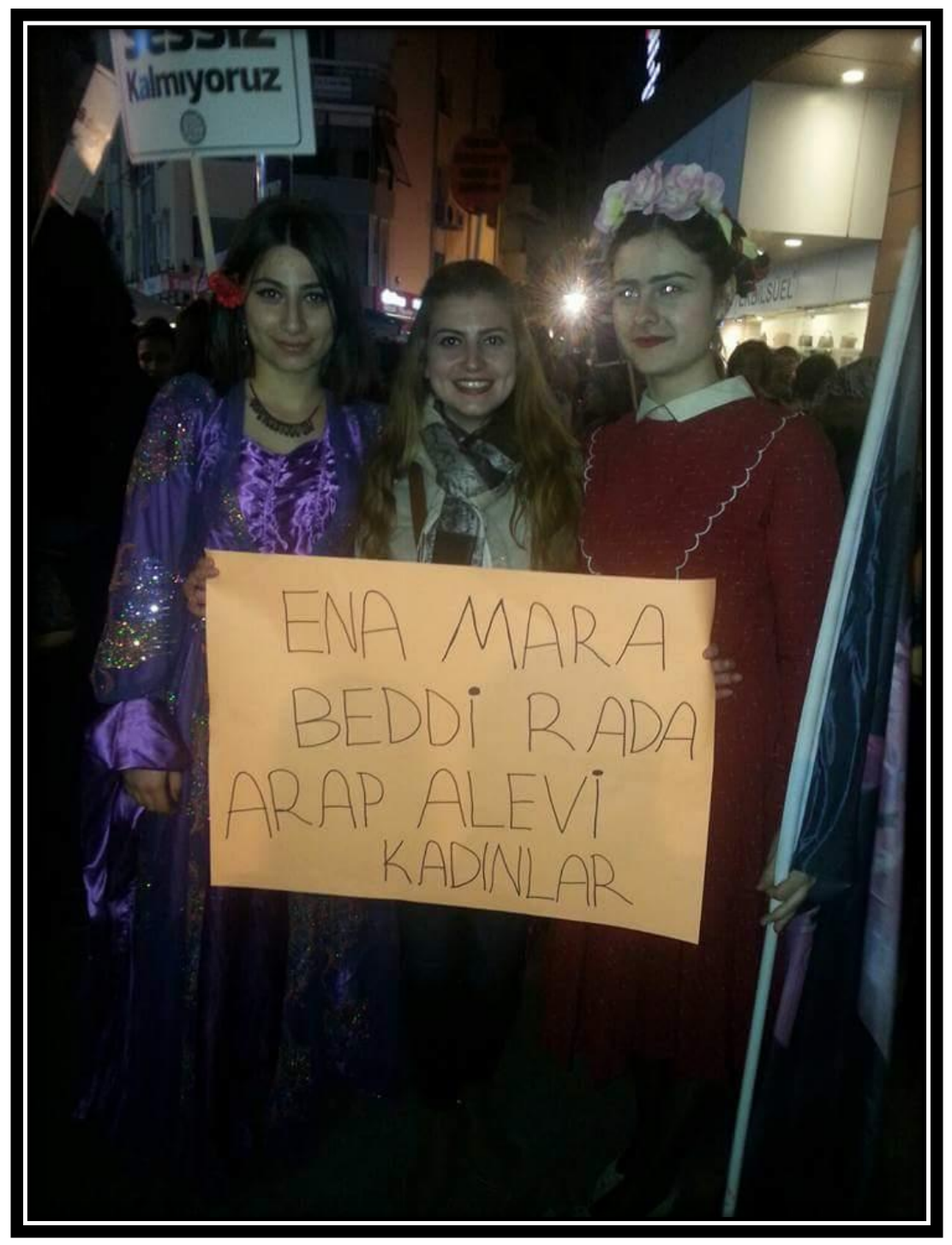

Figure 6.8. Arab Alawite women holding banner that reads "I am a Woman, I want Peace" (Courtesy of the Arab Alawite Women's Council) 


\section{CHAPTER 7: Conclusion}

This dissertation studies the rise of women's political consciousness among the Arab Alawite community in Antakya through a feminist geopolitical and postcolonial lens. The research is significant in that it not only recognizes, but also centers, the impacts of struggles of Muslim women, who are largely perceived as oppressed subjects by the West (Abu-Lughod, 2002; 2010; Fluri, 2008; 2009; Secor, 2001; 2004; Gokariksel and Secor, 2010). It casts them as agentive citizens in contemporary geopolitical shifts. However, it extends far beyond this empirical focus in its significance, as it applies innovative methodological and conceptual framework that (a) strengthens and complicates the literature on gender and nationalism through the insights of feminist political geography such as the embodied experiences of nationalism, gendered state and political violence, and (b) opens up new avenues of feminist geographic research by putting feminist methodologies to work in studies of Middle Eastern geopolitics, such as feminist nation-building, Muslim women's political activism and minority politics. Lastly, the theoretical implications of this research can be applied to studies of women's resistance and activism, as well as the powerful effects of nationalism, and statecitizen relations, far beyond the region of the Middle East.

I began by investigating Antakya's annexation by Turkey in 1939 and the colonial involvement of France, who silenced Syrian discontent on the matter. There were many tensions and anxieties around the annexation, which were fueled by a coercive Turkish nationalistic vision. The various ethnic and religious minority 
groups that had been living in and around Antakya for centuries were either dispersed from the region (like the Armenians) or became subjected to vigorous assimilation schemes. While many Arab Alawites in the region opted for the other side of the border, namely Syria, many of them remained in Antakya, becoming citizens of Turkey literally overnight. They were told that they were in fact "Hittite Turks" who had forgotten their mother tongue. Antakya was now "Hatay" and "Hatay" had always been a Turkish territory and "Hatay" was finally reunited with the "motherland". I underlined the gendered language found in the archival records regarding Hatay's "reunification" with Turkey, reinforcing the theory that nationalism is always gendered (McClintock, 1997). I went beyond the national archival records, however, and triangulated my findings with oral historical accounts from Antakya. There are important strives by the Arab Alawite community to own their history and challenge the Turkish narrative of the annexation period. The oral history project implemented by the Research Institute for the Middle Eastern Arab Peoples is a pivotal step in this direction.

I then moved on to a brief description of the Arab Alawite faith and how the belief system excludes women from certain religious spaces. While many women resented this exclusion, others were pleased with some of its outcomes, which for them meant increased freedom in religious faith/practice and less religious pressures. I framed this concept as the "accidental benefit of religious exclusion". Still, most women expressed their wish for religious knowledge to be more accessible to women and wanted to have the choice to be more involved. One major 
reason for this desire was the fact that many women felt they were "inadequate Arab Alawites" and did not have sufficient knowledge about their own religion. This left them open to attacks from the majority Sunni community, unable to defend their belief system. In that sense, these women viewed religious knowledge as "power". I also discussed how women as wives and mothers carry most of the responsibility on their shoulders when it comes to cultural preservation.

In Chapter 4, I set out to explain why Arab Alawites are largely drawn towards leftist and socialist movements in Turkey, as do many other ethnic and religious minority groups. This is tied to the fact that leftist, socialist, and communist movements are class-based struggles, disregarding ethnicity, religion, and other cultural markers, at least in theory. This allows for marginalized groups to have a voice and express themselves, while building alliances cross-culturally. Such movements are also more inclusive of women, though not completely observing gender equality in practice. Nevertheless, leftist movements in Antakya provided an opportunity for women to politicize and sowed the seeds of feminist ideology, which came into fruition later. Fascinating accounts from former socialist women, many of them who were sentenced after the 1980 coup d'état, vividly brought out tensions around gender during that era. This chapter in general, helped set the scene for women's politicization in Antakya, demonstrating how Arab Alawite women started off with an egalitarian, socialist ideology and ran with it, forming their own feminist agenda down the road. Another major point I raised in this chapter is the "rise of the Arab Alawite identity" in Turkey. Alawites today are more comfortable with 
expressing their identity compared to a decade ago. This is largely connected to the Syrian Conflict, which has pushed them to question their roots and ties to Syria and their place within Turkish society.

The main focus of the following chapter was the identity construction of Arab Alawite women, who for the most part viewed themselves as more independent, empowered and progressive. Here I put into work the theoretical concept of "embodied performances of identity" by Gokariksel and Secor (2010). The more relaxed dress code in the Alawite community, in addition to the fact that Alawism does not require women to cover their hair, emboldens Alawite women to view themselves as secular, modern and empowered. I was given a list of other reasons for the seeming empowerment of Alawite women, which I described in detail in this chapter, such as their democratic family structure, Alawism as a secular belief system, Alawite women's contribution to the household economy, and the importance placed on girls' education. An important factor to women's growing independence and decision-making autonomy was also tied to Alawite men's migration abroad, which leaves women in charge of the household. While most women lamented this reality, which doubled their burden at home, some women pointed towards the 'silver lining', suggesting the phenomenon contributed to women's resilience and empowerment. I ended the chapter with a thorough discussion of the construction of Arab Alawite women as religious and sexual deviants, applying Nagel's (2003) concept of "ethnosexual frontiers and crossings". 
In the final chapter, I put feminist geopolitical theory to work, in analyzing Arab Alawite women's resistance tactics to male hegemony, state oppression, and patriarchal social codes. Alawite women are resisting such structures through every day, individual acts and through organized political and feminist efforts, thus changing the political and social landscape in Antakya, and Turkey. I showed how women are rewriting themselves as social and political agents through interrupting male dominated work sectors, having the courage to go through divorce, owning their mother tongue Arabic, educating themselves on feminism and reaching out to other women, taking a stance against patriarchal practices within leftist and socialist organizations, and mobilizing Arab Alawite women on cultural and political issues. This chapter brings together key concepts of feminist geopolitics in demonstrating that geopolitics is embodied and intimate, it is experienced on multiple scales that are dependent on each other, and that women and the marginalized have agency, which is often overlooked.

\subsection{Contribution to Feminist Geopolitics and Postcolonial Feminism}

Since I have been on this research journey, I have encountered a multitude of indigenous and innovative feminist scholarship that disrupts and extends the primarily white and Anglo American scholarship in feminist political geography (Kandiyoti, 1991; Göle, 1997; Mahmood, 2001; Abu-Lughod, 2002; Aldikacti Marshall, 2008; Caglayan, 2008; Bora, 2008; Badran, 2009; Ozkaleli, 2009; Arat, 2010; Diner and Toktaş, 2010; Gökarıksel and Secor, 2010; Gürhan, 2010; Gümüşçü, 2010; Gökalp, 2010; Ozçürümez and Cengiz, 2011; Akkaya, 2015). While these 
scholars come from a variety of disciplinary backgrounds and not all of them might identify as 'feminist' scholars, their work is invaluable in bringing a deeper analysis into the study of women and citizenship in post-Ottoman Turkey and Middle East. Their works have been a source of inspiration for me and have guided me along the way.

Bora calls for an analysis that takes into account the strategies and actions of political subjects, which will not only provide a deeper understanding of the overall political geography in the region, but also strengthen the explanations that feminist theory has to offer (2008: 57). By doing just that, this dissertation disrupts and extends feminist political geography and postcolonial feminism in two major ways. First, it shows how issues and goals that hold importance for Western women are not always relevant to the experiences of women in the Middle East. For example, consuming alcohol in public spaces might not seem like a 'big deal' for women in the West, but it is for women in Turkey, as is wearing short shorts ${ }^{94}$. Furthermore, due to its geopolitical position, issues related to war, violence, and jihadists hold great importance for Alawite women in Antakya. They are preoccupied with and organize around such concerns. Another example is the epidemic women's killings across the

\footnotetext{
${ }^{94}$ Women who wear short shorts in public are increasingly being harassed, even beaten, by men across the country.
} 
country, which led to the \#sendeanlat movement ${ }^{95}$. These are only some of the culture- and geography-specific issues that are on the agenda of women in Turkey.

The second major contribution of my work is in its expansion of feminisms within Islamic societies (Badran, 2009). Feminist movements in the Middle East have different goals and are based on different needs. For example, up until recently women in Saudi Arabia were fighting for their right to drive, and again up until recently, Sunni women in Turkey were fighting for their right to wear the headscarf in public institutions. Being able to vote or run for public office, having the freedom to wear the headscarf or not, the right to abortion, etc. changes depending on the state and culture, which significantly shape women's struggles. This dissertation demonstrates how Arab Alawite women, too, have different needs based on their minority status and unique culture. For example, their struggles and frustrations are built around their right to their mother tongue Arabic, not being subject to Sunni religious education, and dealing with criticisms for not wearing the headscarf or not knowing certain details about their religious belief. Thus, while they collaborate and build alliances with women from all backgrounds, they also talk about the possibility of an Arab Alawite women's movement (discussed in Chapter 6.6). Aside from their leftist and socialist political affiliations, Alawite women are searching for different avenues that addresses their culture-specific needs.

\footnotetext{
${ }^{95}$ Using the hashtag \#sendeanlat (tell your story), women have told of their experiences of violence, intimidation and harassment, as well as tactics they have resorted to, such as wearing a wedding ring or getting off a bus early to avoid being the last passenger (The Guardian).
} 


\subsection{Wider Impacts}

This research project contributes to literatures on minority struggles and women's politicization in three distinct ways. These contributions can roughly be assessed on the regional Middle Eastern scale, on the nation-state Turkish scale, and the localized scale of the Arab Alawite minority community. First, this research contributes to existing literature on the minority question in the Middle East in the post-Ottoman era. Through an analysis Western colonial involvement and colonial practices of the Ottoman Empire, it shows how the legacies of colonialism continue to shape the current social, political, and economic experiences of minority groups. Additionally, it examines through what platforms Alawites interact with other minority movements in the wider region.

At the nation-state scale, the research teases out important questions regarding the status and treatment of Turkey's ethnic and religious minorities. Through focusing on the Arab Alawite experience, it further creates a platform to discuss the fate of various minorities in the country and contribute to the possibility of a "more positive politics" (Dowler \& Sharp, 2001). My fieldwork hints at how Arab Alawites are actively connecting to other minorities in the country and are trying to build solidarity in their struggle for cultural survival. Finally, this research builds onto the limited scholarship on Arab Alawites in Turkey, which for the most part has taken a historical approach, but has left out important political enunciations. The particular theoretical and empirical approach elaborates on the Arab Alawite experience on multiple scales by paying attention to the gendered 
nationalist discourse and highlight the importance of religion in state politics. The embodied experiences of Alawites elucidate the statist practice of producing 'Turkish' citizens and how Alawites are actively resisting cultural and political assimilation. We see this resistance through the revival of the Arabic language, the increasing ease in saying "I am Arab Alawite", and the cultural and political demands made upon the Turkish state.

More importantly, we see how Alawite women are resisting hegemonic masculinity inflicted by the state and certain social codes. I showed how these women are engaging in acts of resistance that are intimate, such as divorce or not covering their heads, as well as that are organized, such as feminist camps and street protests. I also gave examples of how Alawite women are assuming roles of authority and leadership within their community, in typically masculine spaces. Such concrete examples break the homogenous view of women in the Muslim Middle East and shifts the discourse on Muslim women.

I embarked on this research, querying why Arab Alawite women had such high political consciousness and were so active, quickly realizing that their current subjectivity is entangled with the legacy of colonialism and the history of political and social movements in the region. While I answered my initial questions on what makes Antakya such a politically charged space, how Alawites are resisting statist assimilation, how this particular Islamic sect dis/empowers women, and how women are constructing their religious identity, there are also new questions that emerged during the research and writing process. To begin with, how are Arab 
Alawites collaborating with other ethnic and religious minorities in the region?

Through which issues and platforms do they connect? What are their common points of action? How are Alawite women building alliances with women in other minority groups? I briefly explore these questions in the section below, building a case for a future research study.

\subsection{Future Implications: Prospects for Research on Arab Alawite Relations with other Minorities}

As Mertcan stated in his book, Arab Alawites are actively connecting and building alliances with other ethnic and religious minorities (2014: 351). During my fieldwork, I came across instances of connection and solidarity between Alawites and other minority groups. While I would have liked to investigate this further, I also realized it requires much more elaborate research. What I have found so far is that Arab Alawites are reaching out and working together with Kurds, Circassians, Arab Christians, Armenians, etc. through community platforms and political parties. For example, The Initiative for the Friendship of Peoples (Halklarin Dostlugu Girisimi - HDG) tries to unite different ethnic/religious groups and to tear down the walls built by the state. Singer and teacher Nurgul explains:

"The goal of HDG outreach is to establish connections with people who exist on the land we live and with whom we have not come in touch that much. We need to improve this. We had organized a breakfast on October 11th $(2015)$ with Armenians, Circassians and Romas, but we had to postpone because of the Ankara massacre. But the work continues. There is always a wall that the state has created between the people. In all actuality, our pain is mutual, or joy is mutual, there is no reason to be enemies. I can say that we have first and foremost taken down that wall." 
As an Arab Alawite who lives in Antakya, Nurgul strongly believes that people need to resist separatist or discriminatory language coming from the state and embrace each other. She is part of HDG and is a vocalist in a music groups that plays music from the various languages that exist in Turkey. But she believes it must go beyond learning how to sing in other languages:

"Of course it is important to sing in different languages, but everybody could learn one song in another language. What we need to do is to get to know other cultures better. We should go to Armenian weddings, we should get to know their culture better. We are starting to do this. This is part of HDG. We would love for a Roma or Armenian to come play with us. Memorizing and singing a song is not that impactful. There are many people who do this, it's become popular. Ibrahim Tatlises ${ }^{96}$ also sings in Kurdish, but he doesn't do that as an opposition."

The relationship between Arab Alawites and Kurds is more complicated. For the most part, Alawites seemed to disapprove of the Kurdish nationalist movement. However, more recently they have started to empathize with the Kurds, drawing connections to their experience as a minority. HDP politician and lawyer Songul offers her own perspective on the Kurdish-Arab Alawite matter:

"Unfortunately many Arab Alawites, except for the revolutionaries, view Kurds as terrorist and don't understand why they continue fighting. They think they are given everything equally. But what I cannot understand is how Alawites can see themselves as 'Turks'. My mother doesn't speak a word of Turkish, but she identifies as Turkish. This is the result of the system's assimilation... the Kurdish movement probably did affect Arab Alawite to teach Arabic to their kids. I try to speak Arabic with my kids, whereas my parents tried to speak Turkish with us, even though they didn't know enough."

${ }^{96} \mathrm{~A}$ famous Kurdish singer, popular across the country. 
Ceren, a lawyer from Antakya, tells me how this mindset has been changing

recently:

"Within the past 10-15 years, people are embracing their Arab identity more. I base this also on the Kurdish movement, that the Arabs were encouraged by them. I think the Kurdish struggle had a serious effect. It showed the rights to identity and people recognized this. They said, 'if they are Kurdish, we are Arabs', they didn't respond by saying, 'we are Turkish'. This region has been against the Kurds, but they can resonate with embracing your identity. There are people who embrace their Arab identity, but also are pro-state."

Neriman, co-president of the HDP Defne District Office, believes that Gezi Park

protests had an impact on this change of mindset:

"For a long time, Arab Alawites were very close to Armenians and were influenced by their rituals and traditions. Alawites are a very open and tolerant society. They are open to cooperate with other minority groups. They see themselves as equal to other groups. In Serinyol, Alawites have a strong bond with Circassians and Afghans. In Samandag, there is a strong bond with Christians, Arab Christians, Armenians. But for a long time, Arab Alawites took a stance against the Kurdish society. This is because Alawites had a statist mindset. After Gezi, this view began to deteriorate, but before, 'the best Kurd was a dead Kurd'. I am talking about the Alawites who weren't organized (politically conscious). After Gezi, Alawites began seeing the Kurds in a different light and began getting to know them. Also, Alawites supported HDP more because of how the Kurdish resistance (in Syria) stood up against ISIS."

The Kurdish struggle for cultural preservation also seems to have affected the Arab Alawite community. The prime example is the Kurdish resistance to the ban on the Kurdish language, which many Arab Alawites can identify with, although not on a level as extreme. HDP has also served as an umbrella in bringing Arab Alawites and Kurds together, among many other groups and minorities. I was told 
that the Kurdish struggle in Rojava against Islamic State of Iraq and Syria (ISIS) made Arab Alawites in Turkey increasingly support HDP. There are various ways political parties and their members show their support for the Kurdish struggle. For example, during the state-led military operations against Kurdish civilians during the winter of 2015-2016, SYKP members, majority of them Arab Alawites from Antakya, went on a hunger strike standing in solidarity with the Kurdish people.

In short, this topic is an exciting and promising area of research for a better understanding of how marginalized groups connect across religious, ethnic, and political differences in resisting statist oppression in Turkey. It would be fascinating to observe through which channels they connect and what kinds of resistance tactics they use. Particularly, it would be interesting to further investigate HDP as a model political party that embraces all minorities, working class people, women, environmentalists and the LGBT community and how this changes social and political conversations in the greater Middle East.

I would like to end with a statement by Leyla, which I consider a reminder for women across world. She told me:

"From a feminist perspective, the illusion that women are freer here raises the question on why women should feel the need to organize. This is a serious problem we have here for the feminist movement. The relative freedom they have, creates the illusion that women have true freedom. This is an illusion." 
While Leyla is referring to Arab Alawite women in Antakya, this statement rings truth for all women, especially those committed to a feminist agenda. Her statement highlights the 'illusion' of women's freedom and empowerment that largely comes from economic independence and the 'modern' lifestyle. Leyla expresses her concern that the relative freedom Alawite women have, might also pose a challenge for their need to organize. Individual empowerment should not be confused with collective empowerment. As women, where ever we are, we too must not lose sight of our goal of women's collective empowerment. And our struggle shall continue on all levels, as Mohanty eloquently describes:

"Feminist practice as I understand it operates at a number of levels: at the level of daily life through everyday acts that constitute our identities and relational communities; at the level of collective action in groups, networks, and movements constituted around feminist visions of social transformation; and at the levels of theory, pedagogy, and textual creativity in the scholarly and writing practices of feminists engaged in the production of knowledge" (2003: 5). 
List of References

“2019'da klyamet kopacak!” [The world will end in 2019!] Cukurovapress.com. May 6, 2014. Accessed October 05, 2017.

http://www.cukurovapress.com/haberdetay/2019-da-kiyamet-kopacak_/2761

Abu-Lughod, L. (1995) A Community of Secrets: The Separate World of Bedouin Women. Signs, Vol. 10, No. 4, 637-657

Abu-Lughod, L. (2000) Modern Subjects: Egyptian Melodrama and Postcolonial Difference, in Questions of Modernity, ed. Timothy Mitchell. University of California Press

Abu-Lughod, L. (2002) Do Muslim Women Really Need Saving? Anthropological Reflections on Cultural Relativism and Its Others. American Anthropologist, Vol. 104 , No. 3, 783-790

Abu-Lughod, L. (2010) The Active Social Life of "Muslim Women's Rights": A Plea for Ethnography, Not Polemic, with Cases for Egypt and Palestine. Journal of Middle East Women's Studies, Vol. 6, No. 1, 1-45

Abu-Lughod, L. (2012) Living the "Revolution" in an Egyptian Village: Moral Action in a National Space. American Ethnologist, Vol. 39, No. 1, 21-25

Agamben, G. (2005) State of Exception. The University of Chicago Press, Chapter 1, $1-31$

Agnew, J. (2005) Sovereignty Regimes: Territoriality and State Authority in Contemporary World Politics. Annals of the Association of American Geographers, Vol. 95, No.2, 437-461

Agnew, J. (2005) The History of State and Their Territories. Geopolitics, Vol. 10, No. $1,184-187$

Agnew, J. (2006) Religion and Geopolitics. Geopolitics, Vol. 11, No.2, 183-191

Akkaya, G. (2015) Sir Icinde Sir Olanlar - Alevi Kadinlar [The Secret within the Secret - Alevi Women]. Kalkedon Yayincilik

Aldikacti Marshall, G. (2008) A Question of Compatibility: Feminism and Islam in Turkey. Critical Middle Eastern Studies, Vol. 17, No. 3, 223-238

"Aleviler de kadın-erkek eşitliği konusunda kendileriyle yüzleşmeli." Evrensel.net. January 04, 2015. Accessed October 03, 2017. https://www.evrensel.net/haber/101313/aleviler-de-kadin-erkek-esitligikonusunda-kendileriyle-yuzlesmeli 
Alexander, J. (1994) Not Just (Any) Body Can Be a Citizen: The Politics of Law, Sexuality and Postcoloniality in Trinidad and Tobago and the Bahamas. Feminist Review, No. 48, The New Politics of Sex and the State, 5-23

Anderson, B. (1983) Imagined Communities: Reflections on the Origin and Spread of Nationalism. Verso

"Antakya Narrating its Own History." Institute for the Middle Eastern Arab Peoples. October 27, 2016. Accessed October 02, 2017. http://www.arapenstitu.com/en/general/antakya-narrating-its-own-history-2.html Arat, Y. (2010) Religion, Politics and Gender Equality in Turkey: implications of a democratic paradox? Third World Quarterly, Vol. 31, No: 6, 869-884

Atasoy, Y. (2011) Two Imagineries of Citizenship in Turkey: The Republican and "Ethical" Models. International Journal of Politics, Culture, and Society, Vol. 24, 105123

Badran, M. (2009) Feminism in Islam: Secular and Religious Convergences. Oneworld Publications

Bardakci, M. (2015) The Alevi Opening of the AKP Government in Turkey: Walking a Tightrope between Democracy and Identity. Turkish Studies, Vol. 16, No. 3, 349-370

Barraclough, G. (2004) The Revolt Against the West, in Decolonization: Perspectives from Now and Then, ed. Duara, P. Psychology Press

Batuhan Duz, Wikimedia Commons, accessed October 5, 2017. https://tr.wikipedia.org/wiki/Hatay\#/media/File:Hatay_location_districts.png

Bhaba, H. (2004) “Introduction” in The Location of Culture. Routledge, 1-39

Bondi, L. (1990) Feminism, Postmodernism, and Geography: A Space for Women? Antipode, Vol. 22, No. 2, 156-167

Bora, A. (2008) Ortadogu'da Kadin Hareketleri: Farkli Yollar, Farkli Stratejiler [Women's Movements in the Middle East: Different Avenus, Different Strategies]. I. U. Siyasal Bilgiler Fakultesi Dergisi, Vol. 9, No. 39, 55-69

Bryson, V. (2004) Marxism and Feminism: Can the 'Unhappy Marriage' Be Saved? Journal of Political Ideologies, Vol.9, No. 1, 13-30

Bugelski, B. R. (1961) Assimilation Through Intermarriage. Social Forces, Vol. 40, No. $2,148-153$

Butler, J. (1999) Gender trouble: feminism and the subversion of identity. London: Routledge

Butler, J. (2004) Undoing Gender. Routledge 
Caglayan, H. (2008) Voices from the periphery of the periphery: Kurdish women's political participation in Turkey. IAFFE: 17th Annual Conference on Feminist Economics June 19 - June 21, 2008 Torino, Italy. Conference Paper.

Caha, 0. (2004) The Role of the Media in the Revival of the Alevi Identity in Turkey. Social Identities, Vol. 10, No. 3, 325-338

Can, S. (2011) Nusayrilik: Sir ve Direnis [The Nusayri Order: Secrecy and Resistance]. Istanbul Bilgi University. Master's Thesis

Can, S. (2017) Antakya'nin Yarasi, Yurt Disi Kapisi: Erkek Gocmenlik ve Kadin Sorunu [Antaya's Wound, The Door Abroad: Male Migration and Women Issue], in Asi Guluslum: Ah Guzel Antakya, ed. Mertcan, H. Iletisim Yayinlari

Carkoglu, A. (2011) A Precarious Relationship: The Alevi Minority, the Turkish State and the EU. South European Society and Politics, Vol. 16, No. 2, 351-364

Caytas, J. D. (2012) Conundrum of an Immigrant: Assimilation versus Cultural Preservation. Journal of Identity and Migration Studies, Vol. 6, No. 2, 36-54,

Chatterjee, P. (1993) The Nation and Its Women, in The Nation and its Fragments: Colonial and Postcolonial Histories. Princeton University Press

Clark, H. (2013) 'My Life Is Like a Novel': Embodied Geographies of Security in Southeast Turkey. Geopolitics, Vol. 18, No. 4, 835-855

Cope, M. (2004) Placing Gendered Political Acts, in Mapping Women, Making Politics: Feminist Perspectives on Political Geography, ed. Staeheli, L.; Kofman, E.; and Peake, L. Routledge

Crenshaw, K. (1993) Mapping the Margins, Intersectionality, Identity Politics, and Violence against Women of Color. Stanford Law Review, Vol. 43, 1241-1299

Datta, A. (2016) The Intimate City: Violence, Gender and Ordinary Life in Delhi Slums. Urban Geography, Vol. 37, No. 3, 323-342

Davidson, H. "Rape and murder of young woman sparks mass Twitter protest in Turkey." The Guardian. February 16, 2015. Accessed November 04, 2017. https://www.theguardian.com/world/2015/feb/17/turkish-woman-ozgecanaslans-sparks-anti-violence-campaign-sendeanlat.

Diner, C. and Toktaş, S. (2010). Waves of feminism in Turkey: Kemalist, Islamist and Kurdish women's movements in an era of globalization. Journal of Balkan and Near Eastern Studies, Vol. 12, No.1, 41-57

Dittmer, J. (2013) Geopolitical Assemblages and Complexity. Progress in Human Geography, Vol. 38, No. 3, 385-401 
Doğruel, F. and Leman, J. (2009) 'Conduct' and 'Counter-conduct' on the Southern Border of Turkey: Multicultural Antakya. Middle Eastern Studies, 45:4, 593-610

Domosh, M. (1998) Geography and gender: home, again? Progress in Human Geography, Vol. 22, No. 2, 276-282

Dowler, L. and Sharp J. (2001) A Feminist Geopolitics? Space \& Polity, Vol. 5, No. 3, 165-176

Dressler, M. (2008) Religio-Secular Metamorphoses: The Re-Making of Turkish Alevism. Journal of the American Academy of Religion, Vol. 76, No. 2, pp. 280-311

Du Bois, W.E.B. (2006 [1903]) The Souls of Black Folk. Waking Lion Press

Duman, L. (2016) Vatan'in Son Parcasi: Hatay'daki Uluslastirma Politikalari [The Last Piece of the Nation: The Nationalization Politics in Hatay]. Iletisim Yayincilik

Elden, S. (2009) Terror and territory: the spatial extent of sovereignty. University of Minnesota Press

Elson, D. and Pearson, R. (1981) 'Nimble Fingers Make Cheap Workers': An Analysis of Women's Employment in Third World Export Manufacturing. Feminist Review, No. 7, 87-107

Engels, F. (2010 [1884]) The Origin of the Family, Private Property and the State. Penguin Classics

England, K. (1994) Getting Personal: Reflexivity, Positionality and Feminist Research. The Professional Geographer, Vol. 46, No. 1, 80-89

Enloe, C. (1989) Bananas, Beaches and Bases: Making Feminist Sense of International Politics. University of California Press

Enloe, C. (2004) 'Gender' Is Not Enough: The Need for a Feminist Consciousness. International Affairs (Royal Institute of International Affairs 1944-), Vol. 80, No. 1, 95-97

Enloe, C. (2010) The Risks of Scholarly Militarization: A Feminist Analysis. Perspectives on Politics, Vol. 8, No. 4, 1107-1111

Enloe, C. (2013) Masculinities, Policing, Women and International Politics of Sexual Harassment. International Feminist Journal of Politics, Vol. 15, No. 1, 77-81

Ergin, M. (2012) The racialization of Kurdish identity in Turkey. Ethnic and Racial Studies, 1-20

Erhart, I. (2013) Biopolitics and the Gezi Protests. Proceedings of the 2013 International Conference on the Modern Development of Humanities and Social Science, 301-303 
Erickson, L. and Faria, C. (2011) “We want empowerment for our women':

Transnational Feminism, Neoliberal Citizenship, and the Gendering of Women's Political Subjectivity in Post Conflict South Sudan. Signs: Journal of Women in Culture and Society, Vol. 36, No. 3, 627-652

Ethelia, S. (2014) How Religion Oppresses Women. International Open Journal of Religion, Vol. 2, No. 1, 1-6

Fairhurst, J., Ramutsindela, M. and Bob, U. (2014) Social Movements, Protest, and Resistance, in Mapping Women, Making Politics: Feminist Perspectives on Political Geography, ed. Staeheli, L.; Kofman, E.; and Peake, L. Routledge

Fanon, F. (1967) “Algeria Unveiled" in A Dying Colonialism. Grove Press

Fanon, F. [2008] Black Skin, White Masks. Grove Press, Revised Edition

Faria, C. (2013) Staging a New South Sudan in the USA: Men, Masculinities and Nationalist Performance at a Diasporic Beauty Pageant. Gender, Place and Culture, Vol. 20, No. 1, 87-106

Faria, C. (2014) Styling the Nation: Fear and Desire in the South Sudanese Beauty Trade. Transactions of the Institute of British Geographers, Vol. 39, No. 2, 318-330

Faria, C. (2014) "I Want My Children to Know Sudan": Narrating the Long-Distance Intimacies of Diasporic Politics. Annals of the Association of American Geographers, Vol. 104, No. 5, 1052-1067

Faria, C. (2017) Towards a Countertopography of Intimate War: Contouring Violence and Resistance in a South Sudanese Diaspora. Gender, Place \& Culture, Vol. 24, No. 4, 575-593

Fernandes, L. (2013) Transnational Feminism in the United States. NYU Press

Fincher, R. (2004) From Dualisms to Multiplicities: Gendered Political Practices, in Mapping Women, Making Politics: Feminist Perspectives on Political Geography, ed. Staeheli, L.; Kofman, E.; and Peake, L. Routledge

Foucault, M. (1980) Power/Knowledge: Selected Interviews and Other Writings, 1972-1977. Pantheon Books

Fluri, J. (2008) 'Feminist-nation building in Afghanistan: an examination of the Revolutionary Association of the Women of Afghanistan (RAWA)'. Feminist Review Vol. 89, 34-54

Fluri, J. (2009) The beautiful 'other': a critical examination of 'western' representations of Afghan feminine corporeal modernity. Gender, Place and Culture: A Journal of Feminist Geography, Vol. 16, No. 3, 241-257 
Fluri, J. (2009) Geopolitics of Gender and Violence 'from below' Political Geography, Vol. 28, No. 4, 259-265

Gerber, H. (2004) The Limits of Constructedness: Memory and Nationalism in the Arab Middle East. Nations and Nationalism, Vol. 10, No. 3, 251-268

Ghanea, N. (2008) Religious of Minority? Examining the Realization of International Standards in Relation to Religious Minorities in the Middle East. Religion, State and Society, Vol. 36, No. 3, 303-325

Giardina, C. (2010) Freedom for Women: Forging the Women's Liberation Movement, 1953-1970. Gainesville, FL: University Press of Florida

Gilmartin, M. and Kofman, E. (2004) Critically Feminist Geopolitics, in Mapping Women, Making Politics: Feminist Perspectives on Political Geography, ed. Staeheli, L.; Kofman, E.; and Peake, L. Routledge

Gökalp, D. (2010) A gendered analysis of violence, justice and citizenship: Kurdish women facing war and displacement in Turkey. Women's Studies International Forum 33, 561-569

Gokariksel, B. and Secor, A. (2010) Between Fashion and Tesettur: Marketing and Consuming Women's Islamic Dress. Journal of Middle East Women's Studies, Vol. 6, No. $3,118-148$

Göle, N. (1997) Secularism and Islamism in Turkey: The Making of Elites and Counter-Elites. Middle East Journal, Vol. 51, No. 1, 46-58

Goner, 0. (2005) The Transformation of the Alevi Collective Identity. Cultural Dynamics, Vol. 17, No. 2, 107-134

Gopinath, G. (2002) Local Sites/Global Contexts: The Transnational Trajectories of Deepa Mehta's Fire, in Queer Globalizations: Citizenship and the Afterlife of Colonialism, ed. Cruz-Malave, A. and Manalansan, M. New York University Press

Gregory, D. \& Pred, A. (eds) (2007) Violent geographies: fear, terror, and political violence. Routledge

Gregory, D. (2010) Seeing Red: Baghdad and the Event-ful City. Political Geography, Vol. 29, 266-279

Grewal, I. (1998) "On the New Global Feminism and the Family of Nations: Dilemmas of Transnational Feminist Practice" in Talking Visions: Multicultural Feminism in a Transnational Age. Ed. By Ella Shohat. New York: New Museum of Contemporary Art 
"Gülfer Akkaya'dan Alevi Kadınlar üzerine ikinci kitap: Yol Kadındır." AvrupaForum. March 17, 2017. Accessed October 03, 2017. http://avrupaforum.org/gulferakkayadan-alevi-kadinlar-uzerine-ikinci-kitap-yol-kadindir/

Gümüşçü, S. (2010) Class, Status, and Party: The Changing Face of Political Islam in Turkey and Egypt. Comparative Political Studies, Vol. 43, 835-861

Gürhan, N. (2010) Gender and the "Islamist Feminist" Statement. Contemporary Perceptions of Islam in the Context of Science, Ethics, and Art, November Issue, 365383

Haraway, D. (1988) Situated Knowledges: The Science Question in Feminism and the Privilege of the Partial Perspective. Feminist Studies Vol. 14, No. 3, 575-599

Hillstrom, C. "The Power of Oral History: Personal Narratives Take Us Deep Into the Human Rights Stories Hidden Behind the Headlines." YES! Magazine. April 10, 2015. Accessed October 02, 2017. http://www.yesmagazine.org/peace-justice/invisiblehands-voices-from-the-global-economy-1/the-power-of-oral-history

Him, M. S. and Hoşgör, A. G. (2011) Reproductive practices: Kurdish women responding to patriarchy. Women's Studies International Forum 34, 335-344

Hyndman, J. (2001) The Field as Here and Now, Not There and Then. Geographical Review, Vol. 91, No. 1-2, 262-272

Hyndman, J. (2004) Mind the Gap: Bridging Feminist and Political Geography through Geopolitics. Political Geography, Vol. 23, No. 3, 307-322

Isin, E. (2012) Citizenship after Orientalism: An Unfinished Project. Citizenship Studies, Vol. 16, No. 5-6, 563-572

Johnston, L. and Longhurst, R. (2010) The Geography Closest In: The Body Space, Place and Sex. Rowman and Littlefield Publishers, 21-41

Kabeer, N. (1994) The Emergence of Women as a Constituency of Development; The Theoretical Underpinnings of WID; Structuralist Perspectives; and Development from a Gender Perspective, in Reversed Realities: Gender Hierarchies in Development Thought. Verso: London, New York, 1-95

Kandiyoti, D. (1991) Women, Islam, and the State. Philadelphia: Temple University Press

Kaundal, M. and Thakur, B. (2014) A Dialogue on Menstrual Taboo. Indian Journal of Community Health, Vol. 26, 192-195.

Kaya, S. (2009) Yeni Alevi Kadin Kimsliginin Insasinda Kolektif Hafizanin Rolu [The Role of Collective Memory in the Construction of the New Alevi Women Identity]. VI. 
National Sociology Conference, Adnan Menderes University, Aydin, Turkey:

Conference Paper

Kelly, J and Kaplan, M. (2004) "My ambition is much higher than independence": US Power, the UN World, the Nation-State, and Their Critics" in Decolonization:

Perspectives from Now and Then. Routledge, 131-151

Klingorova, K. and Havlicek, T. (2015) Religion and Gender Inequality: The Status of Women in the Societies of World Religions. Moravian Geographical Reports, Vol. 23, No. 2, 2-11

Kobayashi, A. and Peake, L. (1994) Unnatural Discourse: 'Race' and Gender in Geography Gender, Place and Culture: A Journal of Feminist Geography, Vol. 1, No. 2, 225-243

Kobayashi, A. (2001) Negotiating the Personal and Political in Critical Qualitative Research, in Qualitative Methodologies for Geographers: Issues and Debates, ed. Limb, M. and C. Dwyer. Oxford University Press, 55-70

Kocan, G. and Oncu, A. (2004) Citizen Alevi in Turkey: Beyond Confirmation and Denial. Journal of Historical Sociology, Vol. 17, No. 4, 464-489

Kose, T. (2010) Alevi Opening and the Democratization Initiative in Turkey. SETA Policy Report, No. 3, 5-22

Kose, T. (2012) Ideological or Religious? Contending Visions on the Future of Alevi Identity. Identitites: Global Studies in Culture and Power, Vol. 19, No. 5, 576-596

Kricheli-Katz, T. (2013) Choice-Based Discrimination: Labor-Force-Type Discrimination Against Gay Men, the Obese, and Mothers. Journal of Empirical Legal Studies, Vol. 10, 670-695

Kricheli-Katz, T. and Ridgeway, C. (2013) Intersecting Cultural Beliefs in Social Relations: Gender, Race, and Class Binds and Freedoms. Gender \& Society, Vol. 27, 294-318

Laurie, N. with Calla, P. (2004) Development, Postcolonialism, and Feminist Political Geography, in Mapping Women, Making Politics: Feminist Perspectives on Political Geography, ed. Staeheli, L.; Kofman, E.; and Peake, L. Routledge

Lawson, V. (1998) Hierarchical Households and Gendered Migration in Latin America: Feminist Extensions to Migration Research. Progress in Human Geography, Vol. 22, No. 1, 39-53

Lentin, A. (2005) Replacing 'Race': Historicising the 'culture' in multiculturalism. Patterns of Prejudice, 18 
Limb, M. and C. Dwyer (2001) Qualitative Methodologies for Geographers: Issues and Debates. Routledge

Longhurst, R. (1997) (Dis)embodied geographies. Progress in Human Geography, Vol. 21(4): 486-501.

Longhurst, R. (2002) Geography and gender: a "critical" time? Progress in Human Geography Vol. 26(4), 544-552

Lopez, M. (1998) No Body is an Island: Reproduction and Modernization in Puerto Rico in Talking Visions: Multicultural Feminism in a Transnational Age, ed. Shohat, E. The MIT Press

Mahmood, S. (2012) Religious Freedom, the Minority Question, and Geopolitics in the Middle East. Comparative Studies in Society and History, Vol. 54, No. 2, 418-446

Mapcruzin.com, accessed October 5, 2017. http://www.mapcruzin.com/free-mapsturkey/turkey_admin_2006.jpg

Markussen, H. I. (2005) Alevis and Alevism: Transformed Identities. Istanbul: The Isis Press

Marston, S., Jones, J. P., and Woodward, K. (2005) Human Geography without Scale. Royal Geographical Society (with the Institute of British Geographers), Vol. 30, 416432

Massey, D. (1994) Space, Place, Gender. Minneapolis: University of Minnesota Press

Matthews, W. (2014) Pan-Islam or Arab Nationalism? The Meaning of the 1931 Jerusalem Islamic Congress Reconsidered. International Journal of Middle Eastern Studies, Vol. 35, No. 1, 1-22

Mayer, T. (2000) From Zero to Hero: masculinity in Jewish Nationalism in Mayer, T. (eds) Gender Ironies of Nationalism: Sexing the Nation Routledge: London and New York

Mayer, T. (2004) Embodied Nationalisms, in Mapping Women, Making Politics: Feminist Perspectives on Political Geography, ed. Staeheli, L.; Kofman, E.; and Peake, L. Routledge

McClintock, A. (1997) “No Longer in a Future Heaven”: Gender, Race and Nationalism, in Dangerous Liaisons: Gender, Nation and Postcolonial Perspectives. Minnesota Press

McClintock, A., Mufti, A., and Shohat, E. (1997) Dangerous Liaisons: Gender, Nation and Postcolonial Perspectives. Minnesota Press 
McDowell, L. (1993) Space, place and gender relations: Part 1, Feminist Empiricism and the Geography of Social Relations. Progress in Human Geography, Vol. 17, No. 2, 157-179

McDowell, L. (1999) Gender, Identity and Place: Understanding Feminist Geographies. Minnesota

McKay, R. and Whitehouse, H. (2015) Religion and morality. Psychological Bulletin, No. 141, 219-233

Meng, X. and Gregory, R. G. (2005) Intermarriage and the Economic Assimilation of Immigrants. Journal of Labor Economics, Vol. 23, No. 1, 135-174

Mertcan, H. (2014) Turk Modernlesmesinde Arap Aleviler (Tarih Kimlik Siyaset) [Arab Alawites in Turkish Modernization (History Identity Politics)]. Adana, Turkey: Karahan Publishing

Mitchell, T. (1988) Colonizing Egypt. University of California Press

Mitchell, T. (1992) "Orientalism and the Exhibitionary Order" in Colonialism and Culture, ed. By Dirks, N. University of Michigan Press, 289-318

Mitchell, T. (2002) McJihad: Islam in the U.S. Global Order. Social Text 73, Vol. 20, No. 4, 1-18

Mohammad, R. (2001) 'Insiders' and/or 'Outsiders': Positionality, Theory and Praxis in Limb, M. and C. Dwyer (eds) Qualitative Methodologies for Geographers: Issues and Debates. Oxford University Press, 101-117

Mohanty, C. (1991) Under Western Eyes: Feminist Scholarship and Colonial Discourses, in Third World Women and the Politics of Feminism, ed. by C.T. Mohanty, A. Russo and L. Torres. Bloomington: Indiana University Press, 51-80

Mohanty, C. (2003) Feminism Without Borders: Decolonizing Theory, Practicing Solidarity. Duke University Press

Mohyuddin, A., Sheikh, I. and Chaudhry, H. (2015) Bashalini: A Place for Biological Gender Impurities Segregating Women During Menstruation in Kalash. Science International, Vol. 27, 549-554

Monk, J. and Hanson, J. (1982) On Not Excluding Half of the Human in Human Geography. The Professional Geographer, Vol. 34: 11- 23

Mountz, A. (2003) Human Smuggling, the Transnational Imaginary, and Everyday Geographies of the Nation-State. Antipode, Blackwell Publishing, 622-644

Mountz, A. and J. Hyndman. (2006) Feminist Approaches to the Global Intimate. Women's Studies Quarterly, Vol. 34, No. 1-2, 446-463 
Mountz, A., Coddington, K., Catania, R. et al. (2012) Conceptualizing Detention: Mobility, Containment, Bordering, and Exclusion. Progress in Human Geography, Vol. 37, No. 4, 522-541

Nagel, J. (2003) "Sex and Nationalism" in Race, Ethnicity, and Sexuality: Intimate Intersections, Forbidden Frontiers. Oxford University Press

Narayan, U. (1997) "Restoring History and Politics to 'Third World Traditions"” in Dis/locating Cultures/Identitites, Traditions and Third World Feminism. Routledge

Nash, C. (2008) Rethinking intersectionality. Feminist Review, Vol. 89, 1-15

Nayak, A. (2006) After race: Ethnography, race and post-race theory. Ethnic and Racial Studies, Vol. 29, No. 3, 411-430

Oslender, U. (2009) Anti-Geopolitics in International Encyclopaedia of Human Geography, Kitchin, R. \& Thrift, N. (eds). Oxford: Elsevier, Vol. 1, 152-158

Ó Tuathail, G. (1996) Critical geopolitics: The Politics of Writing global space, Routledge.

Ó Tuathail, G. (1996) An anti-geopolitical eye: Maggie O'Kane in Bosnia, 1992-93. Gender, Place and Culture, Vol. 3, No. 2, 171-185

Ozcurumez, S. and Cengiz, F. (2011) On resilience and response beyond value change: Transformation of women's movement in post-1980 Turkey. Women's Studies International Forum 34, 20-30

Ozkaleli, U. (2009) Confronting the Turkish State: Women's Agency, Identity, and the Prospects for Democracy. Syracuse University. Dissertation

Pain, R. (2009) Globalized fear?: Towards an emotional geopolitics. Progress in Human Geography, Vol. 33, No. 4, 466-486

Pain, R. and Staeheli, L. (2014) Introduction: Intimacy Geopolitics and Violence. Area, Vol. 46, No. 4, 344-347

Pratt, G. (1993) Reflections on Post-Structuralism and Feminist Empirics, Theory and Practice. Antipode, Vol. 25, No. 1, 51-63

Pratt, G. and Yeoh, B. (2003) Transnational (counter) topographies. Gender, Place and Culture: A Journal of Feminist Geography, Vol. 10, No. 2, 159-166

Pratt, G. (2004) Working Feminism. Temple University Press

Pratt, G. and Rosner, V. (2006) Introduction: The Global and the Intimate. Women's Studies Quarterly Vol. 34, No. 1/2, 13-24 
Qian, Z. and Lichter, D. (2007) Social Boundaries and Marital Assimilation:

Interpreting Trends in Racial and Ethnic Intermarriage. American Sociological Review, Vol. 72, No. 1, 68-94

Radcliffe, S. (2006) Development and Geography: Gendered Subjects in Development Processes and Interventions. Progress in Human Geography, Vol. 30, No. 4, 524-532.

Rankin, K. (2001) Governing Development: Neoliberalism, Microcredit, and Rational Economic Woman. Economy and Society, Vol. 30, No. 1, 18-37

Rose, G. (1993) Feminism and Geography: An Introduction Feminism and Geography: The Limits of Geographical Knowledge. Blackwell Publishers, 1-16

Rose, G. (1993) Spatial Divisions and Other Spaces: Production, Reproduction and Beyond, in Feminism and Geography: The Limits of Geographical Knowledge. Blackwell Publishers, 113-136

Said, E. (2003) [1978] Orientalism. Penguin Books

Sangster, J. (1994) Telling our Stories: Feminist Debates and the Use of Oral History. Women's History Review, Vol. 3, No. 1, 5-28

Schroeder, R. (1997) Re-claiming land in the Gambia: Gendered property rights and environmental intervention. Annals of the Association of American Geographers, Vol. 87, No. 3, 487

Secor, A. (2001) Toward a Feminist Counter-Geopolitics: Gender, Space and Islamist Politics in Istanbul. Space and Polity, Vol. 5, No. 3, 191-211

Secor, A. (2001) Islamist Politics: Antisystemic or Post-modern Movements? Geopolitics, Vol. 6, No. 3, 117-134

Secor, A. (2004) "There is an Istanbul that Belongs to Me": Citizenship, Space, and Identity in the City. Annals of the Association of American Geographers, Vol. 94, No.2, 352-368

Secor, A. (2007) Between Longing and Despair: State, Space, Subjectivity in Turkey. Environment and Planning D: Society and Space, Vol. 25, 33-52

Secor, A. (2011) Turkey's Democracy: A Model for the Troubled Middle East? Eurosian Geography and Economics, Vol. 52, No. 2, 157-172

"Secularism and the Relationship Between Arab Alawites and the State." Institute for The Middle Eastern Arab People. November 23, 2015. Accessed October 03, 2017. http://www.arapenstitu.com/en/general/secularism-and-the-realitinshipbetweeen-arab-alawites-and-the-state.html 
Sertel, E. (2005) Dini ve Etnik Kimlikleriyle Nusayriler [Nusayris and their Religious and Ethnic Identites]. Ankara: Ütopya Yayınları

Sharma, A. (2008) Introduction (up to page xxv) in Logics of Empowerment: Development, Gender and Governance, in Neoliberal India. Minneapolis: University of Minnesota Press

Sharp, J. (2003) Feminist and Postcolonial Engagements in A Companion to Political Geography ed. J. A. Agnew, K. Mitchell, G.Ó Tuathail Wiley Blackwell, 59-74

Sharp, J. (2004) Doing Feminist Political Geographies in Mapping Women, Making Politics: Feminist Perspectives on Political Geography, ed. Staeheli, Kofman, and Peake. Routledge

Sharp, J. (2009) Geography and Gender: What Belongs to Feminist Geography? Emotion, Power and Change Progress in Human Geography, Vol. 33, No.1, 74-80

Slater, D. (2004) Geopolitics and the post-colonial: rethinking north-south relations. Blackwell

Sluglett, P. (2014) An Improvement on Colonialism? The 'A' Mandates and their Legacy in the Middle East. International Affairs, Vol. 90, No. 2, 413-427

Spivak, G. (2006) In Other Worlds: Essays in Cultural Politics. Routledge

Staeheli, L. and Kofman, E. (2004) Mapping Gender, Making Politics: Toward Feminist Political Geographies, in Mapping Women, Making Politics: Feminist Perspectives on Political Geography. Routledge

Staeheli, L.; Kofman, E.; and Peake, L. (2004) Mapping Women, Making Politics: Feminist Perspectives on Political Geography. Routledge

Stannard, D. (1993) American Holocaust: The Conquest of the New World. Oxford University Press

Starecheski, A. (2014) Squatting History: The Power of Oral History as a HistoryMaking Practice. Oral History Review, Vol. 41, No. 2, 187-216

Stepan, N. (2002) Race, Gender, Science and Citizenship. Gender \& History, Vol. 10, 26-52

Stoler, A. L. (2010) Along the Archival Grain: Epistemic Anxieties and Colonial Common Sense. Princeton University Press

Sultana, A. and Hafeez-ur-Rehman (2014) Visiting Husbands: Issues and Challenges of Women Left Behind. Pakistan Journal of Women's Studies: Alam-e-Niswan, Vol. 21, No.1, 57-70 
Talhamy, Y. (2011) American Protestant Missionary Activity Among the Nusayris (Alawis) in Syrian in the Nineteenth Century. Middle Eastern Studies, Vol. 47, No. 2, 215-236

Talhamy, Y. (2011) Conscription among the Nusayris (Alawis) in the Nineteenth Century. British Journal of Middle Eastern Studies, Vol. 38, No.1, 23-40

Talhamy, Y. (2012) The Nusayri and Druze Minorities in Syria in the Nineteenth Century: The Revolt against the Egyptian Occupation as a Case Study. Middle Eastern Studies, Vol. 48, No. 6, 973-995

Tessler, M. (2009) A History of the Israeli-Palestinian Conflict. Indiana University Press

Tomaney, J. (2014) Region and Place 2: Belonging. Progress in Human Geography, 110

Trauger, A. and Fluri, J. (2014) Getting Beyond the "God Trick": Toward Service Research. The Professional Geographer, Vol. 66, No. 1, 32-40

Trouillot, M.-R. (2000) Haiti: State Against Nation: Origins and Legacy of Duvalierism. Monthly Review Press

Tse, J. (2013) Grounded Theologies: 'Religion' and the 'Secular' in Human Geography. Progress in Human Geography, Vol. 38, No. 2, 201-220

Turk, H. (2005) Alawism and Concealment: The Unclehood Tradition in the Nusayriye in Alevis and Alevism: Transformed Identities. Istanbul: The Isis Press

Valentine, G. (1989) The Geography of Women's Fear. Area, Vol. 21, No. 4, 385-390

Valentine, G. (2007) Theorizing and Researching Intersectionality. The Professional Geographer, Vol. 59, No. 1, 10-21

Wangari, E. (2002) Reproductive Technology: From a Third World Feminist Perspective in Feminist Post-Development Thought: Rethinking Modernity, PostColonialism and Representation, ed. Saunders, K. The University of Chicago Press

Wilkerson, J. A., Yamawaki, N. and Downs, S. D. (2009) Effects of Husbands' Migration on Mental Health and Gender Role Ideology of Rural Mexican Women. Health Care for Women International, Vol. 30, 614-628

Woollacott, A. (2006) Gender and Empire. New York: Palgrave Macmillan.

Wright, M. (2009) Gender and Geography: Knowledge and Activism across the Intimately Global. Progress in Human Geography, Vol. 33, No. 3, 379-386

Wright, M. (2010) Geography and Gender: Feminism and a Feeling of Justice. Progress in Human Geography, Vol. 34, No. 6, 818-827 
Wright, M. (2010) Gender and Geography II: Bridging the Gap -- Feminist, Queer, and the Geographical Imaginary. Progress in Human Geography, Vol. 34, 56-66

Yabiku, S. T., Agadjanian, V., and Sevoyan, A. (2010) Husbands' Labour Migration and Wives' Autonomy, Mozambique 2000-2006. Population Studies, Vol. 64, No. 3, 293-306

Yilmaz, H. (2013) Becoming Turkish: Nationalist Reforms and Cultural Negotiations in Early Republican Turkey 1923-1945. Syracuse University Press

Young, I. (1990) Justice and the Politics of Difference. Princeton University Press Yuval-Davis, N. (1991) The Citizenship Debate: Women, Ethnic Processes and the State. Feminist Review, No. 39, 58-68

Yuval-Davis, N. (1996) Women and the Biological Reproduction of "The Nation". Women's Studies International Forum, Vol. 19, No. 1, 17-24

Yuval-Davis, N. (1997) Women, Citizenship and Difference. Feminist Review, No. 57, $4-27$

Yuval-Davis, N. (1997) 'Theorizing Gender and Nation' in Gender and Nation Sage publications, 1-25

Yuval-Davis, N. (1999) The 'Multi-Layered Citizen'. International Feminist Journal of Politics, Vol. 1, No. 1, 119-136

Yuval-Davis, N. (2009) Women, Globalization and Contemporary Politics of Belonging. Gender, Technology and Development, Vol. 13, No. 1, 1-19

Zisser, E. (2013) The Emergence of Minorities in the Middle East: The Politics of Community in French Mandate Syria. Middle Eastern Studies, Vol. 49, No. 4, 668-671 


\section{APPENDIX}

\section{Interview Matrix}

\begin{tabular}{|c|c|c|c|c|c|c|}
\hline $\begin{array}{l}\text { Interviewe } \\
\mathrm{e} \\
\text { Pseudonym }\end{array}$ & $\begin{array}{l}\mathrm{Ag} \\
\mathrm{e}\end{array}$ & $\begin{array}{l}\text { Se } \\
x\end{array}$ & $\begin{array}{l}\text { Ethnicity/ } \\
\text { Religious } \\
\text { Backgroun } \\
\text { d }\end{array}$ & Origin & Profession & $\begin{array}{l}\text { Date of } \\
\text { Interview }\end{array}$ \\
\hline Ahmet & 30 & $\mathrm{M}$ & $\begin{array}{l}\text { Arab } \\
\text { Alawite }\end{array}$ & $\begin{array}{l}\text { Samandag } \\
\text { Center }\end{array}$ & $\begin{array}{l}\text { Business } \\
\text { Owner }\end{array}$ & $\begin{array}{l}07 / 03 / 201 \\
4\end{array}$ \\
\hline Devrim & 30 & $\mathrm{M}$ & $\begin{array}{l}\text { Arab } \\
\text { Alawite }\end{array}$ & $\begin{array}{l}\text { Samandag } \\
\text { Center }\end{array}$ & $\begin{array}{l}\text { Political } \\
\text { Activist }\end{array}$ & $\begin{array}{l}07 / 14 / 201 \\
4\end{array}$ \\
\hline Zelda & 27 & $\mathrm{~F}$ & $\begin{array}{l}\text { Arab } \\
\text { Alawite }\end{array}$ & $\begin{array}{l}\text { Samandag } \\
\text { Center }\end{array}$ & $\begin{array}{l}\text { Anthropologis } \\
\mathrm{t}\end{array}$ & $\begin{array}{l}07 / 18 / 201 \\
4\end{array}$ \\
\hline Amina & $\begin{array}{l}50- \\
55\end{array}$ & $\mathrm{~F}$ & $\begin{array}{l}\text { Arab } \\
\text { Alawite }\end{array}$ & $\begin{array}{l}\text { Harbiye, } \\
\text { Defne }\end{array}$ & $\begin{array}{l}\text { Silk Business } \\
\text { Owner }\end{array}$ & $\begin{array}{l}07 / 20 / 201 \\
4\end{array}$ \\
\hline Leyla & 35 & $\mathrm{~F}$ & $\begin{array}{l}\text { Arab } \\
\text { Alawite }\end{array}$ & $\begin{array}{l}\text { Samandag } \\
\text { Center }\end{array}$ & $\begin{array}{l}\text { Politician; } \\
\text { Medical } \\
\text { Supplies } \\
\text { Business } \\
\text { Owner } \\
\end{array}$ & $\begin{array}{l}07 / 22 / 201 \\
4\end{array}$ \\
\hline Bahar & $\begin{array}{l}40- \\
45\end{array}$ & $\mathrm{~F}$ & $\begin{array}{l}\text { Arab } \\
\text { Alawite }\end{array}$ & $\begin{array}{l}\text { Samandag } \\
\text { Center }\end{array}$ & Accountant & $\begin{array}{l}07 / 23 / 201 \\
4\end{array}$ \\
\hline Behra & $\begin{array}{l}35- \\
40\end{array}$ & $\mathrm{~F}$ & $\begin{array}{l}\text { Arab } \\
\text { Alawite }\end{array}$ & $\begin{array}{l}\text { Affan, } \\
\text { Antakya }\end{array}$ & Cook & $\begin{array}{l}07 / 23 / 201 \\
4\end{array}$ \\
\hline Gulizar & 25 & $\mathrm{~F}$ & $\begin{array}{l}\text { Arab } \\
\text { Alawite }\end{array}$ & $\begin{array}{l}\text { Samandag } \\
\text { Center }\end{array}$ & $\begin{array}{l}\text { Social Studies } \\
\text { Teacher }\end{array}$ & $\begin{array}{l}07 / 23 / 201 \\
4\end{array}$ \\
\hline Hayri & $\begin{array}{l}35- \\
40\end{array}$ & M & $\begin{array}{l}\text { Turkish } \\
\text { Sunni }\end{array}$ & $\begin{array}{l}\text { Antakya } \\
\text { Center }\end{array}$ & Scientist & $\begin{array}{l}07 / 28 / 201 \\
4\end{array}$ \\
\hline Nilay & $\begin{array}{l}45- \\
50\end{array}$ & $\mathrm{~F}$ & $\begin{array}{l}\text { Arab } \\
\text { Alawite }\end{array}$ & $\begin{array}{l}\text { Samandag } \\
\text { Center }\end{array}$ & $\begin{array}{l}\text { Animal Feed } \\
\text { Business } \\
\text { Owner }\end{array}$ & $\begin{array}{l}07 / 28 / 201 \\
4\end{array}$ \\
\hline Serdar & 38 & $\mathrm{M}$ & $\begin{array}{l}\text { Arab } \\
\text { Alawite }\end{array}$ & $\begin{array}{l}\text { Sutasi, } \\
\text { Samandag }\end{array}$ & Waiter & $\begin{array}{l}07 / 29 / 201 \\
4\end{array}$ \\
\hline Hakki & $\begin{array}{l}30- \\
35 \\
\end{array}$ & $\mathrm{M}$ & $\begin{array}{l}\text { Turkish } \\
\text { Sunni }\end{array}$ & $\begin{array}{l}\text { Antakya } \\
\text { Center }\end{array}$ & Manager & $\begin{array}{l}07 / 29 / 201 \\
4\end{array}$ \\
\hline Nilda & 35 & $\mathrm{~F}$ & $\begin{array}{l}\text { Arab } \\
\text { Alawite }\end{array}$ & $\begin{array}{l}\text { Samandag } \\
\text { Center }\end{array}$ & $\begin{array}{l}\text { English } \\
\text { Teacher }\end{array}$ & $\begin{array}{l}07 / 30 / 201 \\
4\end{array}$ \\
\hline Cemre & $\begin{array}{l}45- \\
40\end{array}$ & $\mathrm{~F}$ & $\begin{array}{l}\text { Arab } \\
\text { Alawite }\end{array}$ & $\begin{array}{l}\text { Samandag } \\
\text { Center }\end{array}$ & $\begin{array}{l}\text { Education } \\
\text { Center } \\
\text { Founder }\end{array}$ & $\begin{array}{l}10 / 13 / 201 \\
5\end{array}$ \\
\hline Yesim & 34 & $\mathrm{~F}$ & $\begin{array}{l}\text { Arab } \\
\text { Alawite }\end{array}$ & $\begin{array}{l}\text { Tekebasi, } \\
\text { Samandag }\end{array}$ & Accountant & $\begin{array}{l}10 / 13 / 201 \\
5\end{array}$ \\
\hline
\end{tabular}




\begin{tabular}{|c|c|c|c|c|c|c|}
\hline Sevil & 40 & F & $\begin{array}{l}\text { Arab } \\
\text { Alawite }\end{array}$ & $\begin{array}{l}\text { Samandag } \\
\text { Center }\end{array}$ & $\begin{array}{l}\text { High School } \\
\text { Vice Principal; } \\
\text { Literature } \\
\text { Teacher }\end{array}$ & $\begin{array}{l}10 / 13 / 201 \\
5\end{array}$ \\
\hline Fidan & 40 & $\mathrm{~F}$ & $\begin{array}{l}\text { Arab } \\
\text { Alawite }\end{array}$ & $\begin{array}{l}\text { Koyunoglu, } \\
\text { Samandag }\end{array}$ & $\begin{array}{l}\text { Child-care, } \\
\text { Part time }\end{array}$ & $\begin{array}{l}10 / 13 / 201 \\
5\end{array}$ \\
\hline Gulsen & 40 & $\mathrm{~F}$ & $\begin{array}{l}\text { Arab } \\
\text { Alawite }\end{array}$ & $\begin{array}{l}\text { Samandag } \\
\text { Center }\end{array}$ & $\begin{array}{l}\text { English and } \\
\text { Arabic } \\
\text { Teacher }\end{array}$ & $\begin{array}{l}10 / 13 / 201 \\
5\end{array}$ \\
\hline Nuray & 55 & $\mathrm{~F}$ & $\begin{array}{l}\text { Arab } \\
\text { Alawite }\end{array}$ & $\begin{array}{l}\text { Antakya } \\
\text { Center }\end{array}$ & $\begin{array}{l}\text { Event } \\
\text { Planning } \\
\text { Business } \\
\text { Owner }\end{array}$ & $\begin{array}{l}10 / 16 / 201 \\
5\end{array}$ \\
\hline Nur & 40 & $\mathrm{~F}$ & $\begin{array}{l}\text { Arab } \\
\text { Alawite }\end{array}$ & $\begin{array}{l}\text { Mersin } \\
\text { Center }\end{array}$ & Office Worker & $\begin{array}{l}10 / 19 / 201 \\
5\end{array}$ \\
\hline Hakan & $\begin{array}{l}30- \\
35\end{array}$ & M & $\begin{array}{l}\text { Arab } \\
\text { Alawite }\end{array}$ & $\begin{array}{l}\text { Harbiye, } \\
\text { Defne }\end{array}$ & $\begin{array}{l}\text { Café Owner; } \\
\text { Musician }\end{array}$ & $\begin{array}{l}10 / 20 / 201 \\
5\end{array}$ \\
\hline Nil & $\begin{array}{l}30- \\
35\end{array}$ & $\mathrm{~F}$ & $\begin{array}{l}\text { Arab } \\
\text { Alawite }\end{array}$ & $\begin{array}{l}\text { Serinyol, } \\
\text { Antakya }\end{array}$ & Homemaker & $\begin{array}{l}10 / 21 / 201 \\
5\end{array}$ \\
\hline Feride & $\begin{array}{l}30- \\
35\end{array}$ & $\mathrm{~F}$ & $\begin{array}{l}\text { Arab } \\
\text { Alawite }\end{array}$ & $\begin{array}{l}\text { Antakya } \\
\text { Center }\end{array}$ & $\begin{array}{l}\text { Computer } \\
\text { Business } \\
\text { Owner }\end{array}$ & $\begin{array}{l}10 / 21 / 201 \\
5\end{array}$ \\
\hline Bilge & $\begin{array}{l}30- \\
35\end{array}$ & $\mathrm{~F}$ & $\begin{array}{l}\text { Arab } \\
\text { Alawite }\end{array}$ & $\begin{array}{l}\text { Serinyol, } \\
\text { Antakya }\end{array}$ & $\begin{array}{l}\text { High School } \\
\text { Literature } \\
\text { Teacher }\end{array}$ & $\begin{array}{l}10 / 21 / 201 \\
5\end{array}$ \\
\hline Sevim & 26 & $\mathrm{~F}$ & $\begin{array}{l}\text { Arab } \\
\text { Alawite }\end{array}$ & $\begin{array}{l}\text { Mizrakli, } \\
\text { Samandag }\end{array}$ & Accountant & $\begin{array}{l}10 / 22 / 201 \\
5\end{array}$ \\
\hline $\mathrm{Naz}$ & 35 & $\mathrm{~F}$ & $\begin{array}{l}\text { Arab } \\
\text { Alawite }\end{array}$ & $\begin{array}{l}\text { Samandag } \\
\text { Center }\end{array}$ & Secretary & $\begin{array}{l}10 / 22 / 201 \\
5\end{array}$ \\
\hline Nurgul & 31 & $\mathrm{~F}$ & $\begin{array}{l}\text { Arab } \\
\text { Alawite }\end{array}$ & $\begin{array}{l}\text { Gumusgoze, } \\
\text { Defne }\end{array}$ & $\begin{array}{l}\text { Teacher; } \\
\text { Singer }\end{array}$ & $\begin{array}{l}10 / 23 / 201 \\
5\end{array}$ \\
\hline Belgin & 26 & $\mathrm{~F}$ & $\begin{array}{l}\text { Arab } \\
\text { Alawite }\end{array}$ & $\begin{array}{l}\text { Magaracik, } \\
\text { Samandag }\end{array}$ & $\begin{array}{l}\text { Office } \\
\text { Management }\end{array}$ & $\begin{array}{l}10 / 29 / 201 \\
5\end{array}$ \\
\hline Ozge & 31 & $\mathrm{~F}$ & $\begin{array}{l}\text { Arab } \\
\text { Alawite }\end{array}$ & $\begin{array}{l}\text { Armutlu, } \\
\text { Defne }\end{array}$ & $\begin{array}{l}\text { Sales } \\
\text { Representativ } \\
\text { e }\end{array}$ & $11 / 7 / 2015$ \\
\hline Selda & 25 & $\mathrm{~F}$ & $\begin{array}{l}\text { Arab } \\
\text { Alawite }\end{array}$ & $\begin{array}{l}\text { Marsuklu, } \\
\text { Samandag }\end{array}$ & $\begin{array}{l}\text { Lab } \\
\text { Technician }\end{array}$ & $\begin{array}{l}11 / 14 / 201 \\
5\end{array}$ \\
\hline Sevgi & 33 & $\mathrm{~F}$ & $\begin{array}{l}\text { Arab } \\
\text { Alawite }\end{array}$ & $\begin{array}{l}\text { Odabasi, } \\
\text { Antakya }\end{array}$ & $\begin{array}{l}\text { Singer; } \\
\text { Elementary } \\
\text { School } \\
\text { Teacher }\end{array}$ & $\begin{array}{l}11 / 19 / 201 \\
5\end{array}$ \\
\hline Berrin & 35 & $\mathrm{~F}$ & $\begin{array}{l}\text { Arab } \\
\text { Alawite }\end{array}$ & $\begin{array}{l}\text { Harbiye, } \\
\text { Defne }\end{array}$ & Psychologist & $\begin{array}{l}11 / 25 / 201 \\
5\end{array}$ \\
\hline
\end{tabular}




\begin{tabular}{|c|c|c|c|c|c|c|}
\hline Melike & 23 & $\mathrm{~F}$ & $\begin{array}{l}\text { Arab } \\
\text { Alawite }\end{array}$ & $\begin{array}{l}\text { Serinyol, } \\
\text { Antakya }\end{array}$ & $\begin{array}{l}\text { Student; } \\
\text { Theatre } \\
\text { actress }\end{array}$ & $\begin{array}{l}11 / 30 / 201 \\
5\end{array}$ \\
\hline Songul & 42 & $\mathrm{~F}$ & $\begin{array}{l}\text { Arab } \\
\text { Alawite }\end{array}$ & $\begin{array}{l}\text { Samandag } \\
\text { Center }\end{array}$ & $\begin{array}{l}\text { Lawyer; } \\
\text { Politician }\end{array}$ & $\begin{array}{l}12 / 02 / 201 \\
5\end{array}$ \\
\hline Nurdan & 41 & $\mathrm{~F}$ & $\begin{array}{l}\text { Arab } \\
\text { Alawite }\end{array}$ & Tekebasi & $\begin{array}{l}\text { Animal Feed } \\
\text { Business Co- } \\
\text { Owner }\end{array}$ & $\begin{array}{l}12 / 02 / 201 \\
5\end{array}$ \\
\hline Naciye & $\begin{array}{l}55- \\
60\end{array}$ & F & $\begin{array}{l}\text { Turkish } \\
\text { Sunni }\end{array}$ & Ankara & $\begin{array}{l}\text { Unionist; } \\
\text { Teacher }\end{array}$ & $\begin{array}{l}12 / 01 / 201 \\
5\end{array}$ \\
\hline Burcak & 40 & $F$ & $\begin{array}{l}\text { Arab } \\
\text { Alawite }\end{array}$ & $\begin{array}{l}\text { Affan, } \\
\text { Antakya }\end{array}$ & Lawyer & $\begin{array}{l}12 / 03 / 201 \\
5\end{array}$ \\
\hline Nima & $\begin{array}{l}55- \\
60\end{array}$ & $\mathrm{~F}$ & $\begin{array}{l}\text { Arab } \\
\text { Alawite }\end{array}$ & $\begin{array}{l}\text { Tarsus, } \\
\text { Mersin }\end{array}$ & Lawyer & $\begin{array}{l}12 / 09 / 201 \\
5\end{array}$ \\
\hline Neriman & 36 & $\mathrm{~F}$ & $\begin{array}{l}\text { Arab } \\
\text { Alawite }\end{array}$ & $\begin{array}{l}\text { Cekmece, } \\
\text { Defne }\end{array}$ & $\begin{array}{l}\text { Politician, } \\
\text { Activist }\end{array}$ & $\begin{array}{l}12 / 17 / 201 \\
5\end{array}$ \\
\hline Nesrin & 28 & F & $\begin{array}{l}\text { Arab } \\
\text { Alawite }\end{array}$ & $\begin{array}{l}\text { Deniz, } \\
\text { Samandag }\end{array}$ & Homemaker & $\begin{array}{l}12 / 31 / 201 \\
5\end{array}$ \\
\hline Nimet & 35 & $\mathrm{~F}$ & $\begin{array}{l}\text { Arab } \\
\text { Alawite }\end{array}$ & $\begin{array}{l}\text { Meydankoy, } \\
\text { Samandag }\end{array}$ & Secretary & $\begin{array}{l}12 / 31 / 201 \\
5\end{array}$ \\
\hline Remzi & 50 & M & $\begin{array}{l}\text { Arab } \\
\text { Alawite }\end{array}$ & $\begin{array}{l}\text { Magaracik, } \\
\text { Samandag }\end{array}$ & Lawyer & $\begin{array}{l}01 / 15 / 201 \\
6\end{array}$ \\
\hline Filiz & $\begin{array}{l}45- \\
50\end{array}$ & $\mathrm{~F}$ & $\begin{array}{l}\text { Arab } \\
\text { Alawite }\end{array}$ & $\begin{array}{l}\text { Samandag } \\
\text { Center }\end{array}$ & $\begin{array}{l}\text { Community } \\
\text { Organizer; } \\
\text { Activist }\end{array}$ & $\begin{array}{l}01 / 16 / 201 \\
6\end{array}$ \\
\hline Tahir & 57 & $M$ & $\begin{array}{l}\text { Arab } \\
\text { Alawite }\end{array}$ & $\begin{array}{l}\text { Dursunlu, } \\
\text { Defne }\end{array}$ & $\begin{array}{l}\text { Elementary } \\
\text { School } \\
\text { Teacher }\end{array}$ & $\begin{array}{l}01 / 20 / 201 \\
6\end{array}$ \\
\hline Birgul & 40 & $\mathrm{~F}$ & $\begin{array}{l}\text { Arab } \\
\text { Alawite }\end{array}$ & $\begin{array}{l}\text { Antakya } \\
\text { Center }\end{array}$ & Journalist & $\begin{array}{l}01 / 20 / 201 \\
6\end{array}$ \\
\hline Nazan & 35 & $\mathrm{~F}$ & $\begin{array}{l}\text { Arab } \\
\text { Alawite }\end{array}$ & $\begin{array}{l}\text { Armutlu, } \\
\text { Defne }\end{array}$ & $\begin{array}{l}\text { Community } \\
\text { Organizer }\end{array}$ & $\begin{array}{l}01 / 29 / 201 \\
6\end{array}$ \\
\hline Ceren & 44 & $\mathrm{~F}$ & $\begin{array}{l}\text { Arab } \\
\text { Alawite }\end{array}$ & $\begin{array}{l}\text { Affan, } \\
\text { Antakya }\end{array}$ & Lawyer & $\begin{array}{l}02 / 02 / 201 \\
6\end{array}$ \\
\hline Behice & 44 & F & $\begin{array}{l}\text { Arab } \\
\text { Alawite }\end{array}$ & $\begin{array}{l}\text { Modernevler } \\
\text { Iskenderun/ } \\
\text { Tekebasi, } \\
\text { Samandag }\end{array}$ & Homemaker & $\begin{array}{l}02 / 04 / 201 \\
6\end{array}$ \\
\hline Halime & 46 & F & $\begin{array}{l}\text { Arab } \\
\text { Alawite }\end{array}$ & Dover, Defne & $\begin{array}{l}\text { Landscaping } \\
\text { Business } \\
\text { Owner }\end{array}$ & $\begin{array}{l}02 / 08 / 201 \\
6\end{array}$ \\
\hline Kerim & 33 & M & $\begin{array}{l}\text { Arab } \\
\text { Alawite }\end{array}$ & $\begin{array}{l}\text { Samandag } \\
\text { Center }\end{array}$ & $\begin{array}{l}\text { Mathematics } \\
\text { Teacher }\end{array}$ & $\begin{array}{l}02 / 08 / 201 \\
6\end{array}$ \\
\hline
\end{tabular}




\begin{tabular}{|c|c|c|c|c|c|c|}
\hline Besime & 26 & F & $\begin{array}{l}\text { Arab } \\
\text { Alawite }\end{array}$ & $\begin{array}{l}\text { Tekebasi, } \\
\text { Samandag }\end{array}$ & $\begin{array}{l}\text { Public } \\
\text { Relations }\end{array}$ & $\begin{array}{l}02 / 11 / 201 \\
6\end{array}$ \\
\hline Rima & 25 & $\mathrm{~F}$ & $\begin{array}{l}\text { Arab } \\
\text { Alawite }\end{array}$ & $\begin{array}{l}\text { Odabasi, } \\
\text { Antakya }\end{array}$ & Student & $\begin{array}{l}02 / 11 / 201 \\
6\end{array}$ \\
\hline Yeliz & 46 & $\mathrm{~F}$ & $\begin{array}{l}\text { Arab } \\
\text { Alawite }\end{array}$ & $\begin{array}{l}\text { Harbiye, } \\
\text { Defne }\end{array}$ & Lawyer & $\begin{array}{l}02 / 16 / 201 \\
6\end{array}$ \\
\hline Izzet & 30 & $M$ & $\begin{array}{l}\text { Arab } \\
\text { Alawite }\end{array}$ & $\begin{array}{l}\text { Ekinci, } \\
\text { Antakya }\end{array}$ & Lawyer & $\begin{array}{l}02 / 16 / 201 \\
6\end{array}$ \\
\hline Ali & 49 & M & $\begin{array}{l}\text { Arab } \\
\text { Alawite }\end{array}$ & $\begin{array}{l}\text { Samandag } \\
\text { Center }\end{array}$ & Pharmacist & $\begin{array}{l}02 / 18 / 201 \\
6\end{array}$ \\
\hline Celal & 45 & M & $\begin{array}{l}\text { Arab } \\
\text { Alawite }\end{array}$ & $\begin{array}{l}\text { Samandag } \\
\text { Center }\end{array}$ & $\begin{array}{l}\text { Pharmacist; } \\
\text { Sheikh }\end{array}$ & $\begin{array}{l}02 / 18 / 201 \\
6\end{array}$ \\
\hline Burcu & 64 & F & $\begin{array}{l}\text { Arab } \\
\text { Alawite }\end{array}$ & $\begin{array}{l}\text { Aknehir, } \\
\text { Samandag }\end{array}$ & Class Teacher & $\begin{array}{l}02 / 20 / 201 \\
6\end{array}$ \\
\hline Pelin & 55 & $\mathrm{~F}$ & $\begin{array}{l}\text { Turkish } \\
\text { Sunni }\end{array}$ & $\begin{array}{l}\text { Antakya } \\
\text { Center }\end{array}$ & $\begin{array}{l}\text { Printing } \\
\text { House Owner; } \\
\text { Politician }\end{array}$ & $\begin{array}{l}02 / 24 / 201 \\
6\end{array}$ \\
\hline Hilal & 40 & $\mathrm{M}$ & $\begin{array}{l}\text { Arab } \\
\text { Alawite }\end{array}$ & $\begin{array}{l}\text { Samandag } \\
\text { Center }\end{array}$ & $\begin{array}{l}\text { Medical } \\
\text { Supplies } \\
\text { Business } \\
\text { Owner; } \\
\text { Activist }\end{array}$ & $\begin{array}{l}02 / 29 / 201 \\
6\end{array}$ \\
\hline Dima & 54 & $\mathrm{~F}$ & $\begin{array}{l}\text { Arab } \\
\text { Alawite } \\
\text { /Kurdish } \\
\text { Alevi }\end{array}$ & $\begin{array}{l}\text { Dortayak, } \\
\text { Antakya }\end{array}$ & Lawyer & $\begin{array}{l}03 / 01 / 201 \\
6\end{array}$ \\
\hline Mahir & 46 & $M$ & $\begin{array}{l}\text { Arab } \\
\text { Alawite }\end{array}$ & $\begin{array}{l}\text { Karaagac, } \\
\text { Iskenderun }\end{array}$ & $\begin{array}{l}\text { Mechanical } \\
\text { Engineer; } \\
\text { Unionist }\end{array}$ & $\begin{array}{l}03 / 15 / 201 \\
6\end{array}$ \\
\hline Saime & 26 & $F$ & $\begin{array}{l}\text { Arab } \\
\text { Alawite }\end{array}$ & $\begin{array}{l}\text { Turfanda, } \\
\text { Yayladagi }\end{array}$ & Student & $\begin{array}{l}03 / 15 / 201 \\
6\end{array}$ \\
\hline Buse & 31 & $F$ & $\begin{array}{l}\text { Arab } \\
\text { Alawite }\end{array}$ & $\begin{array}{l}\text { Harbiye, } \\
\text { Defne }\end{array}$ & $\begin{array}{l}\text { Insurance } \\
\text { Broker; } \\
\text { Politician }\end{array}$ & $\begin{array}{l}03 / 15 / 201 \\
6\end{array}$ \\
\hline Ipek & 23 & $\mathrm{~F}$ & $\begin{array}{l}\text { Arab } \\
\text { Alawite }\end{array}$ & $\begin{array}{l}\text { Harbiye, } \\
\text { Defne }\end{array}$ & $\begin{array}{l}\text { Building } \\
\text { Technician }\end{array}$ & $\begin{array}{l}03 / 16 / 201 \\
6\end{array}$ \\
\hline Necmi & 45 & M & $\begin{array}{l}\text { Arab } \\
\text { Alawite }\end{array}$ & $\begin{array}{l}\text { Tekebasi, } \\
\text { Samandag }\end{array}$ & $\begin{array}{l}\text { Elementary } \\
\text { School } \\
\text { Teacher; } \\
\text { Musician }\end{array}$ & $\begin{array}{l}03 / 20 / 201 \\
6\end{array}$ \\
\hline Inci & 50 & $\mathrm{~F}$ & $\begin{array}{l}\text { Arab } \\
\text { Alawite }\end{array}$ & $\begin{array}{l}\text { Antakya } \\
\text { Center }\end{array}$ & Homemaker & $\begin{array}{l}03 / 25 / 201 \\
6\end{array}$ \\
\hline Nazife & 29 & $\mathrm{~F}$ & $\begin{array}{l}\text { Arab } \\
\text { Alawite }\end{array}$ & $\begin{array}{l}\text { Mizrakli, } \\
\text { Samandag }\end{array}$ & $\begin{array}{l}\text { Electrical } \\
\text { Engineer }\end{array}$ & $\begin{array}{l}06 / 12 / 201 \\
6\end{array}$ \\
\hline
\end{tabular}


VITA

\section{DEFNE SARSILMAZ}

Born, Phoenixville, Pennsylvania, United States

2006

B.A., International Communications

Ursinus College

Collegeville, Pennsylvania

2011

Undergraduate Certificate, Journalism

University of Massachusetts at Amherst

Amherst, Massachusetts

2014

Graduate Certificate, Women and Gender Studies

Florida International University

Miami, Florida

2016

M.A., Global and Sociocultural Studies

Florida International University

Miami, Florida

2017

Ph.D., Global and Sociocultural Studies

Florida International University

Miami, Florida

$2012-2017 \quad$ Teaching Assistant

Florida International University

Miami, Florida

2017

Academic Coach

Florida International University

Miami, Florida

\section{PUBLICATIONS and PRESENTATIONS}

Sarsilmaz, Defne

"Şelmo Oil Field: A Micro-site of Global Climate Change and the Global Intimate", book chapter in Systemic Crises of Global Climate Change: Intersections of race, class and gender (Routledge Advances in Climate Change Research). ed. by Phoebe Godfrey, Denise Torres. Routledge: 2016 
Sarsilmaz, Defne

"Epistemology of war and military geographies: Empiricism, Ethics, and Race". Panelist. American Association of Geographers, Boston, MA. April 5-9, 2017

Sarsilmaz, Defne

"Arab Alawite Women of Antakya: Agents of Social and Political Change". Paper

presented to the American Association of Geographers, Boston, MA. April 5-9, 2017

Sarsilmaz, Defne

"Project Motherland: Antakya's Annexation in 1939 and its Implications for its Arab Alawite Population". Paper presented to the Association for the Study of the Middle East and Africa, Washington, D.C. October 27-29, 2016

Sarsilmaz, Defne

"Gendering Antakya: Reconfiguring Arab Alawite Women through a Feminist Geopolitical Lens". Paper presented to Association of American Geographers, Chicago, IL. April 21-25, 2015

Sarsilmaz, Defne

"Gendering Antakya: Re-negotiating ethno-religious subjectivities among ArabAlawite Women". Paper presented to the Florida Society of Geographers, Jacksonville, FL. February 6-8, 2015

Sarsilmaz, Defne

"Antakya as an Assemblage: Tracing the Syrian Conflict and Occupy Gezi Movement in the Periphery". Paper presented to Association of American Geographers, Tampa, FL. April 8-12, 2014

Sarsilmaz, Defne

"Foreign Oil Companies and Intersections of Tension in Southeast Turkey". Paper presented to Im/Mobilities and Dis/Connections Conference, Florida International University, Miami, FL. May 4, 2013

Sarsilmaz, Defne

"The Politics of Oil in Southeast Turkey: A Deeper Look into Local Tensions Produced by Foreign Oil Companies". Paper presented to Dimensions of Political Ecology Conference, University of Kentucky, Lexington, KY. February 28, 2013 